$$
\begin{aligned}
& \text { UNIVERSIDADE DE SÃO PAULO } \\
& \text { ECA - ESCOLA DE COMUNICAÇÃO E ARTES } \\
& \text { PROGRAMA DE PÓS-GRADUAÇÃO EM ARTES }
\end{aligned}
$$

CARLOS WEINER MARIANO DE SOUZA

O CORPO DA ARTE:

\title{
A EXPERIÊNCIA DA IMAGEM NO ENSINO CONTEMPORÂNEO DAS ARTES VISUAIS
}


CARLOS WEINER MARIANO DE SOUZA

\section{O CORPO DA ARTE:}

\section{A EXPERIÊNCIA DA IMAGEM NO ENSINO CONTEMPORÂNEO DAS ARTES VISUAIS}

Tese apresentada à Escola de Comunicação e Artes da Universidade de São Paulo como exigência parcial para obtenção do título de doutor em Artes Visuais.

Área de Concentração: Teoria, Ensino e Aprendizagem da Arte; Linha de Pesquisa: Fundamentos do Ensino e Aprendizagem da Arte.

Orientadora: Profa. Dra. Maria Christina de Souza Lima Rizzi. 
A pesquisa que resultou neste trabalho contou com apoio da Coordenação de Aperfeiçoamento de Pessoal de Nível Superior - Ministério da Educação (CAPES/MEC), Bolsa Demanda Social, pelo período de 48 meses. 

convencional ou eletrônico, para fins de estudo e pesquisa, desde que citada a fonte

Serviço de Biblioteca e Documentação

Escola de Comunicações e Artes da Universidade de São Paulo

Dados fornecidos pelo(a) autor(a)

Souza, Carlos Weiner Mariano de

O corpo da arte: : A experiência da Imagem no Ensino

Contemporâneo da Arte / Carlos Weiner Mariano de Souza. - -

São Paulo: C. W. M. Souza, 2017.

200 p.: il.

Tese (Doutorado) - Programa de Pós-Graduação em Artes

Visuais - Escola de Comunicações e Artes / Universidade de São Paulo.

Orientador: Maria Christina de Souza Lima Rizzi

Bibliografia

1. Arte-Eduação 2. Arte Contemporânea 3. Poéticas

Contemporâneas nas Artes Visuais 4. Ensino Contemporâneo nas Artes Visuais 5. Estética I. Rizzi, Maria Christina de Souza Lima II. Título. 
TERMO DE APROVAÇÃO 


\section{DEDICATÓRIA}

Quem foi que disse que eu escrevo para as elites?

Quem foi que disse que eu escrevo para o bas-fond?

Eu escrevo para a Maria de Todo o Dia.

Eu escrevo para o João Cara de Pão.

Para você, que está com este jornal na mão...

E de súbito descobre que a única novidade é a poesia,

O resto não passa de crônica policial — social — política.

E os jornais sempre proclamam que "a situação é crítica"!

Mas eu escrevo é para o João e a Maria,

Que quase sempre estão em situação crítica!

E por isso as minhas palavras são quotidianas como o pão nosso de cada dia

E a minha poesia é natural e simples como a água bebida na concha da mão.

MARIO QUINTANA

A cor do invisível, 1989.

Para minha companheira Cinthia, que é Maria.

Com certeza é o amor que tu me tens,

que ainda me guia. 


\section{AGRADECIMENTOS}

As inquietações que originaram essa pesquisa advêm de um processo de vivência e atuação profissional como educador no campo das Artes Visuais. Os desafios relacionados às reflexões sobre as provocações interpostas pela Arte Contemporânea, objeto da pesquisa, me remeteram a revisitar ideias, redefinir convicções, enfrentar limites e fronteiras de pensamentos, verdades prédefinidas. Para que isso fosse possível, várias pessoas, de formas distintas e em momentos também distintos, aportaram suas contribuições. A todas elas devo agradecer, em especial às artistas Cláudia França, Marcela Tiboni, Rosana Paulino, Stela Barbieri, Viga Gordilho e José Minerini Neto que enriqueceram a pesquisa, partilhando suas práticas e reflexões. Aos amigos Radamés, Maurício, Tina, Margarete e Sue, pela delicadeza da jornada. Agradeço ainda ao amigo e professor Falcão Vasconcelos por seus depoimentos e sua disponibilidade, e, à professora Maria Flórido César, da Universidade Estadual do Rio de Janeiro.

De forma particular, quero deixar explícito meu agradecimento e minha estima a artista e educadora Lucimar Bello Frange, que aceitou ser sujeito da pesquisa, partilhou seus conhecimentos e experiências, tornando mais prazerosa e estimulante a trajetória da pesquisa.

Agradeço, imensamente, à minha orientadora, Prof.a Maria Christina Rizzi, a quem devo o estímulo para a realização e finalização do trabalho, por sua dedicação, pelo respeito e, sobretudo, pela generosidade com que supervisionou a pesquisa e se dispôs plenamente ao diálogo.

Agradeço também ao programa de Pós-graduação da Escola de Comunicações e Artes (ECA) da Universidade de São Paulo por viabilizar a pesquisa, por meio de um subsídio fundamental à sua execução, materializado na Bolsa Capes-Demanda Social. 


\section{RESUMO}

O pressuposto teórico dessa investigação é que a imagem constitui a célula ou singularidade que aciona as políticas cognitivas de subjetivação e alteridade. Por meio das práticas artísticas e da percepção estética, ela concede sentido ao corpo da educação pela arte. Isso posto, o objetivo teórico da pesquisa foi contribuir para a compreensão dos modos de produção da imagem nas poéticas contemporâneas nas artes visuais e seu papel na experiência estética, examinando sua relação e seus efeitos sobre os processos mediados pelo ensino da arte, a partir da prática de artistas educadores. Entende-se que esse seja um objeto que aborda um fenômeno de caráter contemporâneo, sobre o qual o pesquisador possui pouca ou nenhuma influência, o que justificou a utilização do método de estudo de caso. Para sua efetivação foi definido um ator chave, unidade de análise do estudo de caso. Definiu-se pelo foco no trabalho da pesquisadora, professora e artista contemporânea Lucimar Bello Frange, cuja trajetória destaca-se como referência no contexto artístico e educacional nos últimos 30 anos. A execução da pesquisa de campo foi guiada por três objetivos específicos, todos eles relacionados ao trabalho do ator chave, sendo eles: refletir sobre sua trajetória, no âmbito das poéticas contemporâneas, desde os anos 1990; compreender como a experiência da, e com a imagem se realiza; analisar como são ativadas as políticas cognitivas por meio da experiência com a imagem, com ênfase no projeto/performance intitulado "Desenhos de Comer". A pesquisa assumiu a perspectiva qualitativa e exploratória, suportada por três métodos considerados os mais adequados para abordagem do objeto: pesquisa documental, análise de entrevistas e observação direta participante. Desses métodos foram derivados procedimentos que produziram os dados que foram triangulados por meio de três categorias de pesquisa: prática artística, experiência da, e com a imagem, e, processos pedagógicos. A interpretação dos resultados permitiu organizar os resultados em 3 capítulos: no primeiro deles são discutidos os fundamentos teóricos e realizados diálogos com artistas contemporâneos, o que permitiu sustentar a pesquisa em termos de conceitos e linhas de pensamento; o segundo é dedicado à apresentação do procedimento metodológico utilizado para a execução da pesquisa; o último capítulo apresenta os resultados do estudo de caso e está subdividido em quatro sessões, que apresentam os resultados conforme cada método escolhido, para a seguir realizar o processo de triangulação.

Palavras-chave: Arte, Educação, Práticas artísticas, Imagem, Experiência estética, contemporâneo, Lucimar Bello Frange 


\begin{abstract}
The theoretical assumption of this investigation is that the image constitutes the cell or singularity that triggers the cognitive policies of subjectivation and otherness. Through artistic practices and aesthetic perception, it gives meaning to the body of education through art. Thus, the theoretical objective of the research was to contribute to the understanding of the modes of image production in contemporary poetics in the visual arts and its role in aesthetic experience, examining their relation and its effects on the processes mediated by the teaching of art, from the Practice of educating artists. It is understood that this is an object that addresses a phenomenon of contemporary character, about which the researcher has little or no influence, which justified the use of the case study method. For its effectiveness, a key actor, unit of analysis of the case study was defined. It was defined by the focus on the work of the researcher, teacher and contemporary artist Lucimar Bello Frange, whose trajectory stands out as a reference in the artistic and educational context in the last 30 years. The execution of the field research was guided by three specific objectives, all of them related to the work of the key actor: to reflect on his trajectory, in the context of contemporary poetics, since the 1990s; Understand how the experience of and with the image is realized; To analyze how cognitive policies are activated through experience with the image, with emphasis on the project / performance entitled "Desenhos de Comer." The research assumed the qualitative and exploratory perspective, supported by three methods considered the most appropriate to approach the object: documentary research, analysis of interviews and participant direct observation. From these methods were derived procedures that produced the data that were triangulated through three categories of research: artistic practice, experience of and with the image, and, pedagogical processes. The interpretation of the results allowed us to organize the results into three chapters: the first one discusses the theoretical foundations and the dialogues with contemporary artists that allowed to support the research in terms of concepts and lines of thought; The second is dedicated to the presentation of the methodological procedure used for the execution of the research; The last chapter presents the results of the case study and is subdivided into four sessions, which present the results according to each chosen method, to carry out the triangulation process
\end{abstract}

Key Words: Art, Education, Artistic practices, Image, Esthetic experience, contemporary, Lucimar Bello Frange 


\section{LISTA DE FIGURAS}

Figura 1: Conjunto de Fotogramas 01. Vídeo "Perfume del Pepe".. $\quad 41$

Figura 2: Conjunto de Fotogramas 01. Vídeo "Perfume del Pepe"... 41

Figura 3: A. Rodchenko, Pilha de tábuas na madeireira de Vakhtan, 1930

Figura 4: Fotogramas: vídeo-performance "O Grito" ...................... 46

Figura 5. Exposição "Meus Mitos" - Marcela Tiboni ....................... 48

Figura 6. Exposição "Meus Mitos" - Marcela Tiboni ....................... 48

Figura 7. Estudo para desenho do corpo feminino/ Jônico sob rosto feminino. 2010 - Marcela Tiboni

Figura 8. Arsenal, 2014 - Marcela Tiboni 50

Figura 9. Arsenal, 2014 - Marcela Tiboni 51

Figuras 10. Cadeira de arte de Conduta. (2002-2009) ...................... 54

Figura 11. Planta do Museu da arte útil ........................................ 57

Figuras 12. Museu da arte útil ................................................. 58

Figura 13. Design como ferramenta - construcLab ........................ $\quad 59$

Figura 14. Usina social - ConstructLab ......................................... 59

Figura 15. Obras coletivas (Haia/ Mensageiro) - construcLab ....... 61

Figura 16. O léxico (dicionário) como ferramenta ............................ 61

Figura 17: Espelhamento entre objetivo - hipótese e problemas entre os campos teórico e do estudo de caso no âmbito da pesquisa

Figura 18. Ordem epistemológca da percepção ao conhecimento ... 77

Figura 19. Esquema metodológico ............................................... 78

Figura 20: Síntese da sequência procedimental na seleção e análise documental 80

Figura 21. Esquema da Triangulação de dados 92

Figura 22: Fotografia. Instalações em canteiro de obras. Lucimar Bello Frange, 1989

Figura 23: Fotografia. Instalações em canteiro de obras. Lucimar Bello Frange, 1989 105

Figura 24. Fotogramas. Lucimar Bello Frange. 2006-2010 .............. 107

Figura 25. Fotografia. Autor: Thomaz Harrell. Exposiçao de Lucimar Bello em Brasilia-DF, 1994 108

Figura 26. Fotografia. Autor: Thomaz Harrell. Exposiçao de Lucimar Bello em Brasilia-DF 108

Figura 27. Fotografia. Autor: Thomaz Harrell. Exposição de Lucimar Bello em Brasilia-DF. Desenhos de vestir 1994 
Figura 28. Fotografia. Autor: Thomaz Harrell. Exposição de Lucimar Bello em Brasilia-DF. Desenhos de vestir 1994 ..

Figura 29. Fotografia. Autor: Thomaz Harrell. Exposição de Lucimar Bello em Brasilia-DF. Desenhos de vestir 1994 109

Figura 30. Fotografia. Dias desenhantes. Belém - PA .................... 110

Figura 31. Fotografia. Dias desenhantes. Uberlândia/MG $1 \ldots \ldots \ldots \ldots . . .110$

Figura 32. Fotografia. Dias desenhantes, Uberlândia/MG $2 \ldots \ldots \ldots \ldots . . .111$

Figura 33. Fotografia. Dias desenhantes, Uberlândia/MG 3 .............. 111

Figura 34. Fotografia. Dias desenhantes. Belém - PA 2 .................. 111

Figura 35. Fotografia. Instalação Branco sobre Branco. 1998-2001.. 114

Figura 36. Fotografia. Instalação Branco sobre Branco. 1998-2001.. 114

Figura 37. Fotografia. Instalação Branco sobre Branco. 1998-2001.. 114

Figuras 38. Fotografia. Instalação Manuscriptus ........................... 115

Figuras 39. "Coisas a fazer" ......................................................... 116

Figura 40. "Desenhos de vezes" ................................................ 117

Figura 41. "Viagens pr'a fazer" .................................................... 117

Figuras 42. Cartas ao mar, Poemas e catamentos ............................ 118

Figura 43. Cartas de vírgulas paradas tênues .................................. 119

Figura 44. Cartas de vírgulas paradas tênues ................................. 120

Figura 45. Cartas de vírgulas paradas tênues ................................ 120

Figura 46. Frange, Lucimar. Cartas de polifonia balbúrdia .............. 121

Figura 47. Exposição "Carta cura corte" .......................................... 121

Figuras 48. Saberes da llha de Itaparica. Exposição resultante dos trabalhos realizados nas oficinas desenhantes: Desenhos de Comer

Figura 49. Saberes da llha de Itaparica

Figura 50. Lucimar Bello Frange desenhando, experimentando o suporte digital que estava sendo utilizado na entrevista ................. 132

Figura 51. Maria Eugênia Matricardi - Performance: "Corpo contra 135 conceito"

Figura 52. Cláudia França - Performance: "Cic I o ne". 135

Figura 53. Experimentações coletivas. Travess.ias. Uma pesquisa, 139 3 expedições

Figura 54. Experimentações coletivas. Travess.ias 140

Figura 55. Desenhos de Comer, para Itaparica 2011

Figura 56. Lucimar Bello Frange: Exposição "Linhas, a cidade lentamente

Figura 57. Fotografias. Essência 5'. Angella Conte ........................ 161

Figura 58. Performance "Desenhos de comer" ............................. 170 
Figura 59: Imagens da execução de Desenhos de Comer 171

Figura 60: Organização da mesa e do espaço, Curitiba, 2016

\section{LISTA DE QUADROS}

Quadro 01: relação de entrevistas com o ator chave

Quadro 02: Tratamento das entrevistas com base nos procedimentos da história oral

Quadro 03: Entrevistas complementares artistas educadores ....... $\quad 85$

Quadro 04: Fichas de acompanhamento e registro ........................ 88

Quadro 05: Visitas técnicas, observações e registros de atividades do público 88

Quadro 06: Derivações da análise documental - Trajetória ............ 127

Quadro 07: Derivações da análise de entrevistas ........................... 168

Quadro 08: Derivações da Observação Participante - Oficina

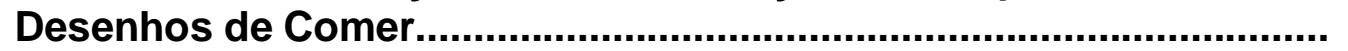




\section{SUMÁRIO}

$\begin{array}{lr}\text { INTRODUÇÃO } & 14\end{array}$

Pontas Soltas 19

CAPÍTULO 1: O CORPO DA ARTE 23

1.1 Estética: de um regime a outro 26

$\begin{array}{ll}1.2 \text { El Perfume de Pepe } & 39\end{array}$

1.3 Tato, cheiro, razão, sentimento, impotência, mobilidade 44

$1.4 \mathrm{~A}$ arte útil: agenciamentos coletivos 52

1.4.1 A polissemia produtiva das experiências: o corpo social da arte na educação

1.5 A experiência da imagem 62

CAPÍTULO 2: MERIDIANOS - DA SINERGIA AO DIAGNÓSTICO 70

$\begin{array}{ll}2.10 \text { nascimento da ordem } & 76\end{array}$

2.2 primeiro meridiano: documentos escritos e iconográficos $\quad 79$

2.2.1 Documentos iconográficos 80

2.3 O segundo meridiano: das entrevistas $\quad 81$

2.4 O terceiro meridiano: observações direta e participante 86

$\begin{array}{ll}2.5 \text { A triangulação de dados } & 91\end{array}$

CAPÍTULO 3: UMA LINHA NO MUNDO - ESTUDO DE CASO SOBRE A ARTISTA E EDUCADORA LUCIMAR BELLO FRANGE

3.1 Trajetória artística e educadora de Lucimar Bello: análise e interpretação documental

3.1.1 Novos contextos, outras formas sem fôrmas 94

3.2 Análise interpretação de Entrevistas $\quad 129$

3.2.1 As Práticas Artísticas por Lucimar Bello Frange 129

3.2.2 A experiência da e com a imagem na perspectiva de Lucimar 149

Bello

3.2.3 Práticas pedagógicas no trabalho de Lucimar Bello 154

3.3 Observação Participante do Trabalho Desenhos de Comer 170

3.4 O processo de triangulação em diálogo com a problemática de 179 pesquisa

$\begin{array}{lr}\text { Apontamentos Finais } & 182\end{array}$

$\begin{array}{lr}\text { Referências' } & 185\end{array}$

Anexo 01: Carta de autorização para uso das entrevistas 200 


\section{INTRODUÇÃO}

Uma educação pela pedra: por lições; para aprender da pedra, frequentá-la; captar sua voz inenfática, impessoal (pela dedicação ela começa as aulas). A lição de moral, sua resistência fria ao que flui e a fluir, a ser maleada; a de poética, sua carnadura concreta; a de economia, seu adensar-se compacta: lições da pedra (de fora para dentro, cartilha muda), para quem soletrá-la.

Outra educação pela pedra: no Sertão (de dentro para fora, e pré-didática). No Sertão a pedra não sabe lecionar, e se lecionasse, não ensinaria nada; lá não se aprende a pedra: lá a pedra, uma pedra de nascença, entranha a alma.

(João Cabral de Melo Neto. A educação pela pedra).

"Pedaços de meus poemas são puro cinema [...] imagem material e visual"1, disse João Cabral de Melo Neto. Na concretude de um sonho e a leveza de uma pedra, carnadura é a presença poética. A (in)sensibilidade que lapida 0 poema e, intencionalmente, interrompe a cantilena. A ordem se dá em poesias linhas, figuratividades abstratas e geometrizações orgânicas ${ }^{2}$. O poeta nos apresenta o que buscamos neste percurso de pesquisa: a voz inefável da pedra, a cartilha muda de letramento ante a dicção concisa e controlada da educação. - A "didática da pedra" nos coloca na posição de educandos e pesquisadores nas artes. A pedra, como a arte é pré-didática, apresenta aquilo que não se ensina e que não se aprende, no entanto, aquilo que não é ensinado é a lição de situar-se nela, de experienciar e encontrar qualidades.

\footnotetext{
${ }^{1}$ MELO NETO, João Cabral. Entrevista concedida à Nícolas Extremera Tapia. Universidade de Granada, Espanha, 1993.

2 João Cabral é um poeta racional, de linguagem catalizadora de metamorfoses. Suas imagens nascem das imagens de uma geografia localizada, da cumplicidade entre o homem e o meio, do equilíbrio entre o vivido e o lembrado, entre o natural e o humano, entre o telúrico e o imaginal que nos acompanha desde o primeiro poema apropriado.
} 
Essas qualidades se traduzem na capacidade de formular objetivos; em experienciar a expressão do significado ${ }^{3}$, em equacionar pensamento e matéria pela unidade proporcionada pelo trabalho ${ }^{4}$; e, finalmente, em desenvolver faculdades que permitam construir juízos que são engendrados à dinâmica cultural, transformando-se em potência ética, estética e democrática no contexto social.

Mas que possibilidades o nosso sistema de ensino oportuniza ao sujeito em processo de formação, principalmente, crianças e adolescentes, para o desenvolvimento das referidas qualidades? Para o aprimoramento de uma consciência interrogante, que permita o enfrentamento de um mundo imerso na imageria ${ }^{5}$ endereçada exclusivamente à formação de um público consumidor? Para inquirir e transpor uma realidade que representa sem cessar a si mesma?

Talvez não seja necessário responder a essas perguntas. É notório que no processo de formação, gerenciado pelas instituições escolares, ainda prevalecem os padrões da lógica dualista, do certo e do errado, que incutem regras preestabelecidas e orientam à uma percepção de mundo calcada em um falso sentido de acordância às regras impostas por um sistema, que em última instância, é valorado e replicado pela ideia de sucesso, pelo vencer na vida.

O que se percebe no cenário nacional, nos últimos anos, é a efetivação de "políticas públicas" que, além de ignorar as potências da representação plástica visual na formação dos sujeitos e do próprio âmbito de dinamização construtiva das múltiplas realidades culturais que compõem a riqueza brasileira, vêm deixando indícios da implementação de um modelo de educação alinhada aos interesses da lógica neoliberal. Um racionalismo econômico cujo auge se deu na década de 1990 e hoje traz como meta, ao campo educacional dos países

\footnotetext{
${ }^{3}$ DEWEY, John. Arte como experiência. São Paulo: Martins Fontes, 2010, p. 126. Dewey afirma que o significado não está limitado àquilo que pode ser afirmado. Esta afirmativa traz uma crítica à orientação metafísica do filósofo Ludwig Wittgenstein.

${ }^{4}$ EISNER. Elliot Wayne. O que pode a educação aprender das artes sobre a educação? In: Currículo sem Fronteira, v.8, n.2,pp.5-17, jul/Dez 2008. Acessado em: 14/10/2014. Disponível em: http://www.curriculosemfronteiras.org/vol8iss2articles/eisner.pdf. Texto proveniente da palestra ministrada pelo autor na Universidade de Stanford, no ano de 2008.

${ }^{5}$ Termo ulizado pelo autor para distinguir as imagens que nascem das operações artísticas e as demais. RANCIÉRE, Jacques. 0 destino das imagens. Tradução Mônica Costa Neto, CONTRAPONTO, Rio de Janeiro, 2012
} 
em desenvolvimento, a ampliação do mercado consumidor e a estabilidade política como forma de manutenção e reprodução dos interesses do capital ${ }^{6}$.

Um alinhamento ideológico que tem seu espelhamento no âmbito educacional por meio das narrativas que se sustentam e se organizam sob a forma de argumentação meritocrática e excludente. Nesse contexto, as experiências com a arte, depois de décadas de empenho de educadores para torná-la uma realidade no ambiente escolar no Brasil, podem vir a perder, inclusive, o pobre status de atividade, nessa lógica. O que a transformaria, quem sabe, em algo para preencher o tempo ocioso em momentos de descanso entre as disciplinas necessárias para o uso "correto" da língua e os cálculos do comércio.

Quando as manifestações de julho do ano de 2013 no Brasil, em função do aumento de 0,20 centavos da passagem de ônibus, se multiplicaram pelo país e, em 2016, estudantes e professores de todo país ocuparam as escolas públicas em resistência às mudanças estruturais no ensino médio, que subjuga, pela força de lei, as humanidades do currículo, sem considerar a opinião de suas entidades representativas, revelou-se ainda existir o que parecia diluído pela liquidez ${ }^{7} \mathrm{da}$ realidade contemporânea. A capacidade utópica. A expressão original de um tempo que, ao desacreditar nas antigas formas de poder, ativou algo inédito. Um movimento sem lideranças, espontâneo, que sem mediações, multiplicou pelos espaços físicos e virtuais as vozes subjetivas e coletivas que não separaram os processos de ser e conhecer da realidade.

Durante muito tempo se atribuiu à educação o papel de principal promotor de ascensão social, contida em uma ideia de futuro. No entanto, o mundo vive hoje, como afirma Foucault, "uma rede que religa pontos e entrecruza sua trama", que atravessa as camadas da vida comum, desfazendo

\footnotetext{
${ }^{6}$ Apresentação de Mr. Shahid Husain, vice-presidente do Banco Mundial para a América Latina e Caribe, na 5a . Reunião do Comitê Regional Intergovernamental do Projeto Principal de Educação para a América Latina e o Caribe, realizada em Santiago do Chile entre 8 e 11 de junho de 1993.

${ }^{7}$ BAUMAN. Zygmunt. Sobre educação e juventude. Rio de Janeiro, Zahar, 2013. O conceito refere-se ao que o autor define como modernidade líquida. Bauman trata dos valores do mundo de consumo que exigem que as pessoas esqueçam hoje o que aprenderam ontem e aprendam hoje o que devem esquecer amanhã. Sua análise se sustenta nas modificações no campo do trabalho, que ultrapassaram a lógica industrial e, agora, se estruturam na lógica de uma sociedade individualizada, na qual a ideia de futuro não tem vigor. O que afetou todas as outras formas de relacionamento humano.

8 FOUCAULT. Michel. Outros espaços. In: Ditos e escritos III. Rio de Janeiro: Forense Universitária, 1995, p.411.
} 
a ideia de uma linearidade temporal e acrescenta às suas incertezas a necessidade do agora do tempo, no qual a ética parece carecer de sentido.

Nesse processo, o que mais cabe aos educadores senão favorecer a arte do discernimento, de qualificação das informações que são recebidas e contribuir para que a relação de ensino e aprendizagem propicie as condições de navegação em uma realidade, cada vez mais, multifacetada?

Imbuída desse espírito, esta investigação procura compreender qual é o papel do ensino da arte, da experiência com e da imagem, em um universo complexo de narrativas que não mais se fixam à ideia de universalidade, à uma concepção de educação que mantém ativo 0 paradigma da compartimentalização do conhecimento, no qual o conteúdo é tratado em sua forma fragmentada, dividida e separada da complexidade da realidade. Coerente com essa perspectiva é que foi assumido como pressuposto teórico da pesquisa, a compreensão de que a imagem constitui a célula ou singularidade capaz de acionar as políticas cognitivas de subjetivação e alteridade. Entende-se que as práticas artísticas e a percepção estética mediam a forma pela qual a imagem concede sentido ao corpo da educação pela arte.

Em tempo, é importante relevar que a perspectiva que deu origem à especialização do conhecimento, bem como ao formato disciplinar e estanque, parece não encontrar mais abrigo nos processos que envolvem o ensino e aprendizagem na atualidade. Depreende-se disso, que o papel que a arte exerce na educação, não passa objetivamente por traduzir a realidade, mas articular uma diversidade de sentidos e significados que ampliam as possibilidades de interpretações.

Nesse contexto, o ensino da arte no Brasil, ao longo de sua jovem história, vem tentando encontrar o seu lugar na educação brasileira. Em que pese a ausência de políticas públicas ${ }^{9}$, o cenário nacional conta, como sempre contou, mesmo enfrentando as contradições históricas, com profissionais que se mantiveram firmes na defesa da educação pela arte, que encontraram em museus, fundações e nos processos de agenciamento ${ }^{10}$ de artistas educadores

\footnotetext{
9 Compreendidas aqui como ações articuladas, com delimitação de objetivos, metas e recursos, executadas pelos poderes públicos que garantam um lugar à arte na educação.

${ }^{10} \mathrm{O}$ conceito de agenciamento encontra respaldo na obra de Deleuze e Guatarri, na elaboração de uma filosofia anti-dicotômica, que desconstrói os fundamentos da lógica hierárquica e verticalizada, na qual os autores apontam para uma construção territorial em torno do desejo.
} 
a potência de levar, sob os nomes de experiência e imagem, as diversas funções que constituem o trabalho da arte na educação.

Elliot W. Einser argumenta em defesa de uma educação como uma preparação artística, destacando a dimensão pedagógica que habita a arte pelo contato epistêmico que se efetiva por meio das faculdades mentais como a percepção, a memória, a imaginação e a reflexão em um processo carnado, a atitude somática que gera a experiência incorporada. Uma orientação que utiliza métodos artísticos para realizar práticas de experiência, e propõe uma aproximação entre o uso de procedimentos artísticos e as experiências derivadas com concepções e práticas da educação"

A expressão "experiência incorporada" utilizada por Eisner ${ }^{12} \mathrm{e}$ pronunciada pelo ator chave desta investigação, a artista, educadora e pesquisadora Lucimar Bello Frange, em uma das entrevistas concedidas no processo de pesquisa, reporta ao conceito "carne vianda" elaborado pelo filósofo Gilles Deleuze ${ }^{13}$, como o estado do corpo em que a carne e os ossos confrontamse localmente.

O sentido atribuído pela educadora à concepção deleuziana apresenta a complexidade de uma zona de indiscernibilidade ${ }^{14}$. Zona que em Herbert Read $^{15}$ emerge como uma mobilização de afetos, sensações e intuições. Uma abordagem que não se fundamenta em leis transcendentais e metafísicas, mas, a propósito da experiência enunciada pela filosofia de John Dewey, brota no plano de ação de um agente, em uma dinâmica que explora os limites do corpo físico, vai além dele, busca respostas e retorna como ação transformadora.

Há na perspectiva desses autores, cada um a seu modo, uma orientação de fundo naturalista e complexa que direcionou esta investigação.

\footnotetext{
Basicamente, o agenciamento apresenta dois eixos, um de interioridade e outro expresso nas linhas de fuga. DELEUZE, G.; GUATARRI, F.. Mil Platôs: capitalismo e esquizofrenia. Vol.1. Rio de Janeiro, Editora 34, 1995.

${ }^{11}$ EISNER. Elliot Wayne. Arts based Research. Los Angeles: Sege Publications. inc.,2012.

12 Idem.

${ }^{13}$ DELEUZE, Guilles. Francis Bacon: Lógica da sensação. Rio de Janeiro: 2007. Tradução Roberto Machado. A expressão foi utilizada por Lucimar Bello Frange em entrevista concedida em sua residência, dia 07/04/2014.

${ }^{14} \mathrm{Na}$ ontologia naturalista do autor, a interface homem/natureza é natural: os humanos são considerados "organismos como os outros, corpos-objetos em interação ecológica com os outros corpos e forças". ALLIEZ, ÉRIC (org) . Gilles Deleuze: Uma vida filosófica. São Paulo, Editora 34, 2000. p.429

15 READ, Herbert. Educação pela arte. Tradução: Ana Maria Rabaça e Luís Felipe Silva Teixeira. EDIÇÕES 70, Ida, 2007.
} 
Além disso, trouxe a abordagem do fenômeno estético como um processo que ativa o corpo em direção a um trabalho cognitivo experimental e experiencial, que se dá por diferenciações na relação objetiva com o ambiente e "deriva de uma concepção de arte como lugar de agenciamentos"16. Trata-se de perceber que "os fios soltos do experimental são energias que brotam para um número aberto de possibilidades"17. As costuras do homem acoplado ao seu animal em uma tautologia ${ }^{18}$ constante. "Esta zona objetiva de indiscernibilidade, já é o corpo, mas o corpo enquanto carne vianda" ${ }^{19}$.

Vianda é organicidade, articulada à proposição de uma educação pela arte, defendida por Read, encontra respaldo na ideia de uma sociedade como um ser orgânico, que "estrutura a vida com apetite e digestão, instintos e paixões, a inteligência e a razão" ${ }^{20}$. E, que em Morin ${ }^{21}$, por meio de uma leitura antropológica da imagem, surge como algo que habita nosso campo inconsciente e nossas viagens, como um elemento fundante dos processos cognitivos humanos desde sua origem.

\section{Pontas soltas}

A necessidade de se pensar a arte na educação, no contexto das transformações contemporâneas, implica afirma-la como um produto da inteligência. Isso, em um sentido que traz a faculdade de conhecer em sua essência etimológica, como a capacidade do indivíduo de fazer escolhas, de atribuir juízos pelas qualidades que nascem do desenvolvimento do pensamento plástico e da potência epistêmica contida na experiência estética em sua unidade com a formação de uma postura ética e política.

\footnotetext{
${ }^{16}$ DELEUZE. G. Conversações. Trad. Bras. Peter Paul Pelbart. São Paulo: Ed. 34. 1992. p. 183 e 188.

17 OITICICA, Hélio. Experimentar o Experimental, 1972.

18 O termo tautologia, que na linguística designa um vício de linguagem, é utilizado aqui nos termos da filosofia, como um valor de verdade atribuído. DUROZOI, G. e ROUSSEL, A. Dicionário de Filosofia. Tradução de Marina Appenzeller. Campinas, SP: Papirus, 1993.

${ }^{19}$ DELEUZE, G.. Francis Bacon: Lógica da sensação. Rio de Janeiro: 2007. op,cit p.27. et seq.

${ }^{20}$ READ. Herbert. Anarchy and order essays in politics Faber. Beaccon Press, Boston-EUA, 1971. (p.21). (Tradução nossa).

${ }^{21}$ MORIN, Edgar. O cinema ou o homem imaginário. Lisboa: Relógio D’Água, 1997. (p.200).
} 
A produção contemporânea nas artes visuais promoveu o deslocamento das práticas artísticas para dentro do corpo social e equalizou a visualidade às distintas narrativas. Processo que está diretamente vinculado à relação dos artistas com seu território ${ }^{22}$ (ateliê), que se expande para o mundo abrindo fissuras e teias, dotando de conteúdo e de expressão sua prática de agenciamento, cuja significação efetiva depende da articulação entre esse campo interior de forças ao campo exterior, das forças centrípetas às centrífugas. No caso da arte contemporânea, essa dinâmica se apresenta no entrelaçamento entre produção e um outro modo de recepção ${ }^{23}$.

Isso posto, toma-se como hipótese que essas tensões ainda não foram assimiladas como problematizações que ampliam as possibilidades do campo educacional, bem como contribuem para construção social do sujeito e dos modos de existência, constituindo um território de autoria. Entende-se que sejam problemas relevantes, compreender: Como essas práticas artísticas, dotadas de uma dinâmica contraditória e complementar, contribuem para as práticas pedagógicas? Como os artistas educadores desenham estratégias para lidar com o processo de ensino e aprendizagem?

Ao se tratar da produção artística contemporânea, especificamente, nas artes visuais e da sua relação com o campo educacional, ainda é de se observar a questão colidente sobre o que é ou não arte, e de que maneira essa produção deve ser considerada nos processos que envolvem o seu ensino e aprendizagem. Uma questão que surge da dificuldade das instituições culturais e educacionais em problematizar as experiências que partem de proposições artísticas que buscam sensórios diferentes ${ }^{24}$.

Read destaca que "não há um tipo de arte a que todos os homens devem se conformar [...] Cada tipo de arte é a expressão legítima de um tipo de

\footnotetext{
22 O conceito de território é utilizado nesta pesquisa nas três dimensões apontadas por Rogério Haesbaert. Jurídico-política, cultural e econômica. O primeiro se refere a um espaço delimitado e controlado sob o qual se exerce um determinado poder, especialmente, de caráter estatal. $\mathrm{O}$ segundo, destaca as dimensões simbólicas e subjetivas um produto da apropriação constituída por meio do imaginário, da identidade social sobre o espaço. $O$ terceiro destaca sua perspectiva material, como produto espacial do conflito entre capital e trabalho. Destaca-se que a segunda definição é a mais relevante neste contexto de pesquisa. HAESBAERT, R.. O Mito da Desterritorialização - do "fim dos territórios" à multiterritorialidade. Bertrand Brasil, Rio de Janeiro, 3ª edição, 2004.

${ }^{23}$ DELEUZE \& GUATARRI, Op. Cit, 1995.

${ }^{24}$ RANCIÉRE, Jacques. Sobre políticas estéticas, Barcelona, Museo de arte contemporáneo de Barcelona (MACBA), zoos, p. 78.
} 
personalidade" 25 , e a negação da produção contemporânea, nada mais é do que expressão do preconceito fundamentado em um distanciamento que desconsidera, sobretudo, a essencialidade do acesso à experiência estética por meio do contato com as práticas artísticas. O que envolve, além da experiência com os trabalhos, a compreensão da própria postura dos artistas diante do mundo.

Em termos de suporte teórico da pesquisa, compreendeu-se que para pensar acerca da experiência da e com as imagens da arte, em uma dimensão ampliada, é necessário investigar, de um lado, o que define a quebra de um pacto social entre os artistas e o público ${ }^{26}$ e, de outro, como a dissolução das convenções artísticas podem afetar o exercício do julgamento estético. Para, a partir daí, considerar a função da arte e a potência das imagens na experiência educacional ${ }^{27}$.

Percebe-se que esse objeto é substantivamente amplo e complexo, além de enfrentar um recorte da realidade que é perfeitamente classificável como contemporâneo, o que sustenta a opção por abordá-lo por meio de um estudo de caso. Para sua realização, foi escolhido um sujeito chave de pesquisa, a artista, educadora e pesquisadora Lucimar Bello Frange.

A discussão teórica, esboçada nessa introdução, subsidiou a definição de objetivos específicos que direcionaram o processo de coleta de dados. $O$ primeiro deles foi refletir sobre a trajetória de Lucimar Bello Frange à luz das práticas artísticas, estabelecendo a década de 1990 como recorte temporal, em que pese as alusões a períodos anteriores a esse marco. O segundo objetivo, imbricado ao primeiro, envolveu compreender como a experiência da e com a imagem se realiza no trabalho da artista. Já o terceiro objetivo estabelecido foi analisar como são ativadas as políticas cognitivas por meio da experiência da imagem. Para esse último objetivo, o foco foi dado ao projeto/performance intitulado "Desenhos de Comer", em função do seu caráter síntese da trajetória do sujeito de pesquisa.

\footnotetext{
${ }^{25}$ Ibidem, p.40.

${ }^{26}$ Duve. Thierry de. Cinco reflexões sobre o julgamento estético. In: Revista Porto Arte: Porto Alegre, V. 16. N. 27, Novembro/2009.

${ }^{27}$ Essa busca foi realizada, tanto em termos de pesquisa bibliográfica, como de imagens, mas também em vivências ao longo da pesquisa que possibilitaram ampliar a compreensão do fenômeno, antes mesmo da implementação do estudo de caso.
} 
Os resultados da pesquisa foram dispostos em três capítulos, sendo que o primeiro está dedicado ao suporte teórico para a análise e interpretação do fenômeno investigado. O capítulo 2 sistematiza o método de abordagem, os procedimentos e instrumentais adotados para a construção do estudo de caso, bem como o processo de análise e interpretação de resultados. O último capítulo traz os resultados da pesquisa empírica apresentado em quatro sessões, cada uma delas dedicada a analisar e interpretar os resultados de um dos métodos de coleta de dados, para em seguida, na última, realizar a triangulação dos resultados. 


\section{Capítulo 1: 0 corpo da arte}

[...] como eu posso ser professora de arte se eu não vou a
exposição de ninguém, se eu não leio sobre arte, se eu não
procuro viver comigo a experiência estética. Não que eu tenha
que fazer, mas a experiência estética do outro. Como eu posso
trabalhar com outros, sem viver a experiência estética em mim ${ }^{28}$

A expressão que dá título à esta pesquisa foi cunhada a partir dos diálogos com a artista, educadora e pesquisadora, Lucimar Bello Frange. Ao se referir à produção contemporânea nas artes visuais, definiu-a como uma fatura, como um movimento de entrada e saída de um todo sistêmico, que promove tensões entre os saberes especializados e não sabidos, que se mobilizam por meio de agenciamentos nos quais ela sustenta as ações estéticas e promove as estesias que dão sentido às ações formativas.

"Viver a experiência estética!" A afirmativa de Frange reporta à relação entre arte e educação como ato criativo, que comporta, ao mesmo tempo, uma maneira de criar para si um território e adentrar outras dimensões da realidade, tendo a experiência estética como elemento ativador. Um fenômeno que move a educação pela arte, destacando-a e/ou aproximando-a dos outros corpos/sistemas de conhecimento, ao mesmo tempo em que edifica um modo próprio de instituir e dar sentido à experiência humana.

O conceito de criatividade, aqui sugerido, não trata de sua concepção filosófica transcendental, que argumenta em pró de uma ideia de genialidade ou dom. Fora dos jargões escolares, que também abrigam o binômio críticoreflexivo com a mesma recorrência que não os define claramente, criatividade aqui é definida como um ato que busca a coerência entre o pensar, o sentir e o fazer, um movimento de vontade do sujeito mediante uma nova possibilidade na qual se permitiu e se descobriu preparado para ser mais do que era anteriormente.

Toda criação está ligada intimamente à potência e à vontade e, como afirma Deleuze ${ }^{29}$, não se encerra na cognição, mas dinamiza-se pela emoção

\footnotetext{
${ }^{28}$ FRANGE, Lucimar Bello. 07/04/2014, São Paulo. Entrevista concedida a Carlos Weiner M. de Souza.

${ }^{29}$ DELEUZE, G. Bergsonismo. Tradução de Luiz Orlandi. São Paulo: Ed. 34 Letras,1999.
} 
que precede a representação, retirando a hegemonia da cognição e da consciência racional na criação. Nesses termos, o conceito de experiência não se traduz em um fenômeno que, por meio dos impulsos da arte, reflete a vida, a emoção do artista, ou os aspectos formais de suas obras ${ }^{30}$, mas sim, o próprio sujeito da experiência. A emoção é criadora porque comunica ao outro e à própria criatividade. É aquilo que excita a vontade no contato experiencial e exige a abertura do sujeito para a potência do encontro com a arte e com o outro.

As modalidades das experiências -sensações, sentimentos, valores, juízos, gostos e representações, são efeitos da experiência estética, que se transformam na esteira da história coletiva e individual. É um modo irradiador da capacidade de construir que habilita os sujeitos ao confronto com as realidades, e destitui a hegemonia das exterioridades que promovem a incapacidade de perceber o mundo além de sua racionalidade instrumental e funcional.

Contudo, a arte contemporânea tornou-se um objeto que não escapa ao pensamento. O público disposto a inquiri-la, as ações educacionais que pretendem com ela estabelecer a permuta de saberes, devem ficar atentos de que não se trata, apenas de uma educação do olhar, da sensibilidade, mas de um processo, de um ato volitivo que deve percorrer as múltiplas camadas desse corpo semântico.

A experiência aurática, o bom gosto e a ideia de beleza ${ }^{31}$, outrora prescritas pelas estéticas tradicionais, não encontram lugar no mundo em que o acesso à experiência estética carece, não apenas do contato com trabalho dos

\footnotetext{
${ }^{30}$ Outro aspecto importante para o ensino da arte, em termos dos fundamentos que orientam a leitura dos objetos artísticos, apenas pelos seus aspectos formais, contém a ideia de que 0 pensamento é uma imagem cognitiva em que só há estruturas lógicas. O que limita o processo de aprendizagem aos esquemas em que as diferenças não são substantivas.

${ }^{31} \mathrm{O}$ destaque ao pensamento kantiano se dá em função de sua obra ter rebatimentos profundos na maneira como o pensamento sobre estética teve, e ainda tem, desdobramentos na prática pedagógica no campo das artes. Dotado de uma visão essencialista, o autor se reporta ao desinteresse, que é o critério de distinção do gosto em relação a juízos, à diferença do cognitivo, envolvem necessariamente o prazer. Em síntese, afirma em sua terceira crítica que onde há conhecimento (stricto sensu) não há sentimento de prazer, e se houver, não se trata de um juízo de conhecimento. Uma concepção que no processo de compartimentação do conhecimento, no qual se sustenta a ideia de uma especialidade proclamada pelo saber científico, como o único válido, estabeleceu hierarquias, cujos princípios, no processo de formação, relegam a um segundo plano os modos perceptuais de compreensão do mundo. As contribuições kantianas aos estudos da subjetividade são imprescindíveis. No entanto, é possível considerar que, sua abordagem fenomenológica do processo epistemológico, ao ser apropriada pela lógica do capital, que ascende com o projeto iluminista de racionalidade, trouxe ao campo educacional, o modelo de uma educação funcionalista, hierarquizado e compartimentado. KANT, Immanuel. Crítica da faculdade do juízo. Forense Universitária, Rio de Janeiro, 2002. (p.126).
} 
artistas, mas com sua atitude. O interesse da arte pelo cotidiano, pelas coisas mínimas, pelas micropolíticas ${ }^{32}$, pelas redes e interações sociais, ao mesmo tempo confluem $\mathrm{e}$ interrogam as novas configurações culturais, cujas características apontam um caminho que se distingue dos purismos e das estratégias discursivas da modernidade. São saberes que não afirmam diretamente qualquer moralidade, não ilustram ou exemplificam, mas potencializam nas obras a marca do outro e, por isso, desafiam nosso modo de pensar e sentir.

Nesse amplo cenário de hibridações, no qual as problemáticas apresentadas dão indícios de um novo sensório, faz-se necessário compreender o embaralhamento entre saberes artísticos e não artísticos, os novos modos de recepção e suas interações com as configurações socioculturais, uma rede que, quando acionada, se configura aquém da vontade e domínio das partes, mas articula o sensível comum que interfere nas maneiras de fazer, nas "maneiras de ser e nas formas de visibilidade" 33 dos atores envolvidos.

A tarefa do artista, como afirma Deleuze, "é tornar visíveis forças que não são visíveis" 34 para que haja a sensação, aquilo que age diretamente no sistema nervoso e provoca as emoções. Assim, atua violando e provocando o dissenso no modo do pensamento. Concepção que torna possível intuir acerca dos propósitos do ensino da arte em sua aproximação com os saberes contidos nas práticas artísticas, como a energia motora de suas ações.

As práticas artísticas contemporâneas denominam, nessa pesquisa, um espaço conceitual e um modo de referência aos processos pedagógicos. Não se referem à formação do artista, mas aos elementos que possibilitam a experiência da e com a imagem como um lugar de agenciamentos, em que se alternam os movimentos centrípetos e centrífugos das interioridades, e, que por meio da experiência estética ativada na ação educativa, promove o processo de reconfiguração constante da realidade, como um processo de construção do conhecimento.

Destarte, este capítulo tem o propósito de contribuir para a compreensão dos modos de produção da imagem nas poéticas contemporâneas nas artes

32 GUATTARI, F.; ROLNIK, S. "Cultura: um conceito reacionário?". In: Micropolítica: cartografias do desejo. Petrópolis: Vozes, 1996.

${ }^{33}$ Idem. A partilha do sensível, pp. 65-67;

${ }^{34}$ DELEUZE, Gilles. Lógica da Sensação. Rio de Janeiro: Jorge Zahar Editora, 2007. p.62. 
visuais e seu papel na experiência estética. Para tanto, aborda as práticas artísticas como um modo de agenciamento (Gilles Deleuze e Felix Guattari); as investiga nas partilhas do sensível (Jacques Rancière), nos endereçamentos da arte (Thierry de Duve), com propósito de pensar o conceito de arte como experiência (John Dewey), na contemporaneidade. Por meio desse trânsito conceitual, que também acessa outros autores, propõe-se o diálogo com as imagens de artistas latinos americanos ${ }^{35}$ e busca-se interrogar as camadas dessa produção para trazer subsídios para reflexões propostas no estudo de caso.

\subsection{Estética: de um regime a outro}

A experiência visual contemplativa requerida para uma obra, a ideia de beleza que deriva das estéticas tradicionais, e na qual parte das práticas pedagógicas se fundamentam, parecem não dialogar com uma produção "que não mais se permite ser representada por narrativas mestras de modo algum" 36 . Esse fenômeno não designa o fim da narrativa, mas sua multiplicidade no contemporâneo, gerando experiências intensas que ainda não foram assimiladas pelo campo pedagógico.

Há, nesse sentido, uma grande dificuldade dos educadores em situarse ante à multiplicidade das manifestações estéticas contemporâneas que suplantam, em grande medida, muitos condicionamentos históricos. Ao que parece, esta questão também está relacionada ao sistema da arte, ou seja, à sua institucionalidade e reporta, necessariamente, ao próprio conceito de imagem e aos circuitos pelos quais ele se move. São territórios em que a

\footnotetext{
${ }^{35}$ O recorte nas práticas de artistas latino americanos se deu em função da própria trajetória de pesquisa. Durante o processo de investigação tornou-se importante compreender as poéticas artísticas contemporâneas cujas experiências buscam a conexão entre memórias/matéria/espaço/política como elementos das narrativas que se colocam nos limites da relação global e glocal. Essa foi uma maneira de encontrar subsídios para pensar os processos do ator chave da pesquisa, cuja poética encontra-se intimamente ligada aos processos de entrada e saídas dos lugares/culturas onde atua. Há nessa escolha o desejo de uma tensão que busca na atual horizontalidade da arte, os confrontos que se estabelecem entre o nacional e o mundo, o popular e o erudito, o periférico e o central, o tradicional e o moderno. Tensões que emergem de formas distintas no trabalho do ator chave da pesquisa, e trazem desafios muito positivos para o ensino e aprendizagem da arte, no contexto brasileiro.

${ }^{36}$ DANTO, A. Após o fim da arte: a arte contemporânea e os limites da história. São Paulo: Odysseus, 2006. (p.25).
} 
produção teórica sobre a arte, seja no campo filosófico, histórico ou da crítica especializada influenciam, substancialmente, os contornos concedidos às ações educativas, posto que interferem, sobremaneira, nas escolhas estéticas e nas possibilidades experienciais e educativas a ela vinculadas.

No entanto, como essa produção teórica é regulada e comunicada pelos sistemas fechados que a produziram (história da arte/crítica e filosofia), chega ao público, particularmente, professores e estudantes, de maneira diferente da que é formulada em sua real genealogia. Essa afirmativa não nega a racionalidade e importância de cada especialidade, mas compreende, a propósito da complexidade, que podem ser definidos como sistemas autopoiéticos, autorreferentes e operacionalmente fechados.

Em sua evolução histórica o sistema das artes promoveu distinções entre seus subsistemas, história da arte, crítica, ensino das artes e formou agentes especializados. Uma segmentação que produz hierarquias, relações centro/periferia, linguagens próprias e um quadro de ocupações para que se tornem funcionais. Nesse sentido, cada subsistema constrói seu próprio conhecimento e estabelece, quando necessário, as conexões com o que lhe é distinto. Quando um subsistema de um sistema se conecta a outro, ou seja, a um ambiente distinto, os significados das informações provenientes dos mesmos acabam por formar camadas descontextualizas, confusas, ou na melhor das hipóteses, simplificadas em excesso ${ }^{37}$.

Desenvolver a reflexão por entre esses sistemas é, sem dúvida, um desafio que deve ser enfrentado por aqueles que se dispõem a perquirir as camadas da arte contemporânea e incorporá-las à dinâmica de ensino e aprendizagem. Principalmente, no sentido de não restringir suas avaliações e condutas às influências dos meios de difusão de informação, um outro sistema que reduz o campo conceitual das referidas áreas a modismos passageiros e alimentam os valores do mercado e do entretenimento. Além, obviamente, de

${ }^{37}$ O que levou ao diálogo com a teoria sistêmica de Luhmann, e trazê-la para o contexto do ensino da arte, foi a observação das dinâmicas das disciplinas que cursadas durante o doutorado. Tanto nas disciplinas relacionadas à crítica, quanto à história da arte, havia um estranhamento por parte dos docentes que as ministravam com a presença de um estudante com o foco no ensino da arte. Dessa forma, incluímos em nosso caderno de campo as observações sobre os problemas elencados em debates e seminários e o distanciamento das citadas áreas no que se refere ao campo educacional. LUHMAN, N. Introdução à teoria dos sistemas: aulas publicadas por Javier Torres Nafarrate. Trad. Ana Cristina Arantes Nasser. Petrópolis: Vozes, 2010. 
oferecer amplo espectro de ideias que podem ser intervenientes na aquisição e mediação de valores relacionados ao consumo e à distinção social, estética e educativa que alimentam os alicerces do distanciamento ou da aproximação do público em geral e, particularmente, de professores e estudantes, em relação à essas manifestações.

Assim, o caminho escolhido para reflexão está em estabelecer as conexões entre eles a partir da ênfase em determinado ponto - as práticas artísticas. $O$ que pode ser refletido pela interação de seus elementos e suas funções no todo comunicacional. Isto é possível nas interseções desses subsistemas, nos territórios onde as visualidades e dizibilidades carecem se conectar. Trata-se, então de transitar entre as proposições que sustentam historicamente as definições de arte, seus movimentos e seus limites. De encontrar nas transformações nos modos de operar dos artistas, uma possibilidade de acessar a natureza epistemológica da arte.

Destarte, inicia-se por meio de um problema conceitual que perpassa a história das práticas artísticas, a questão do julgamento estético que, hoje, em função das transformações dessas práticas, traz em si os conflitos e a dualidade entre os meios e os fins, a ideia de beleza e de gosto e suas relações com o próprio conceito arte e com os modos de abordá-la na dinâmica do ensino e aprendizagem.

Thierry de Duve opera a reflexão sobre esses dualismos confrontando duas interpretações distintas e, auxilia na compreensão das passagens ou transições em que a arte deixa de ser um "saber fazer", uma questão de conformidade poética, para se tornar um sentir heterogêneo. Uma fatura que, como afirma Lucimar Bello Frange, não se reduz a um ofício, mas acontece pelas escolhas, apropriações e estesias que dão sentido a uma outra forma de pensar os meios e os processos na ética da criação.

De Duve aborda o dissenso entre as perspectivas de Joseph Kosuth (artista conceitual) e Clement Greenberg (crítico de arte), ambos com interpretações divergentes sobre as experiências de Marcel Duchamp (readymade). Kosuth reivindica o termo arte para um lugar fora da estética, no campo conceptual, enquanto Greenberg mantém a arte no campo da estética, nos domínios da forma. A solução do autor está na retomada de preceitos kantianos sobre o julgamento estético, e no confronto entre a tese: "isso é arte", não se 
baseia em conceitos, e sua antítese, "isso não é arte", não se baseia em conceitos.

De maneira sintética, o autor desenvolve uma argumentação transversal, que se refere, tanto a uma "inapresentável ideia estética, quanto a uma indemonstrável ideia racional"38. Uma manobra que equaliza, do ponto de vista filosófico, um embate histórico entre as ideias racionalistas e empiristas no campo epistemológico, pelo menos no que concerne à relação entre a arte e a preocupação com a objetividade ou a validade do julgamento estético. No entanto, faz-se necessário, para compreender os argumentos de Thierry de Duve, abordar questões que situam alguns aspectos do pensamento humanista e seus desdobramentos e influências sobre os movimentos das práxis artísticas na história do Ocidente.

A partir da proposição de compreensão e domínio da natureza, os séculos XV e XVI revelaram a abundância de elaborações teóricas baseadas na racionalidade, na lei natural e na liberdade do homem. Ao mesmo tempo em que se libertava da admiração, adoração, obediência frente ao ambiente natural, o homem passava a cultivar novos valores relacionados à individualidade, liberdade, criatividade, participação e enriquecimento. Essa orientação aparece na arte como um aspecto da atitude científica diante da natureza, como nos afirma Osborne, ao refletir sobre a estética renascentista:

\begin{abstract}
É um hábito mental tratar a natureza como algo externo ao homem e separado dele, algo para ser estudado e observado com objetividade científica, senhoreado e aproveitado pelo homem, algo capaz de inspirar reações emocionais, ou de ser espelhado, lisonjeado ou melhorado pela arte ${ }^{39}$.
\end{abstract}

Havia nesse período uma estreita relação entre o interesse nascente pela ciência empírica e o estudo das artes. A arte começou a ser compreendida por meio da mimeses poética de Aristóteles, encontrando nas ciências empíricas seu amparo e orientação. A ideia de uma arte que imita a natureza, foi posteriormente ativada como uma tarefa do artista (representar a natureza). A atividade artística, fundamentalmente a pintura e a escultura, eram consideradas

\footnotetext{
${ }^{38}$ Segundo Thierry de Duve, no vocabulário Kantiano, apresentável significa o que pode ser estabelecido teoricamente, e demonstrável, o que pode ser mostrado aos sentidos. De Duve, Thierry. 1998. op. cit. p. 142. et seq.

${ }^{39}$ OSBORNE, Harold. Estética e teoria da arte - Uma introdução histórica. São Paulo: Cultrix, 1968. p. 118.
} 
um ramo do conhecimento e o artista, em oposição ao artesão, começou a adquirir um novo status social. Assumiu a condição de intelectual e cavalheiro.

Apesar da vida intelectual e artística permanecer sob a tutela da aristocracia e da igreja, atendendo às suas demandas éticas e estéticas, teve início uma progressiva liberação, tanto do ponto de vista econômico, quanto social $^{40}$. Esse processo de autonomização da produção intelectual e artística, iniciado ainda no século XV, seguiu em busca da afirmação de uma legitimidade propriamente artística. O que, por sua vez, gradativamente, foi possibilitando ao artista legislar sobre seu próprio campo em termos de forma e estilo. Dessa maneira, a formalização dos processos de produção das artes, entendidos como um sistema que busca a perfeição racional, tinha referência na antiguidade clássica e na natureza, além de ordenar um conjunto de princípios que proporcionou as bases ao classicismo ensinado nas academias do século XVII ${ }^{41}$.

É possível resgatar essas referências destacando Giorgio Vasari ${ }^{42}$, que ao conceber a história da arte, ainda no século XVI, a partir de uma série de biografias, indicava Michelangelo como um modelo de "artista herói que, drasticamente, à custa de lutas esforços sobre-humanos, supera a natureza na história e a história na ideia". Esse distanciamento foi acompanhado de uma estreita ligação da arte com o espaço em que está inserida (institucionalidade). O que interferiu substancialmente na orientação estética (e na transformação da ideia de experiência com a arte), assumindo uma condição moral relacionada ao lugar, à cidade, à natureza em seu entorno. Em termos explícitos, o propósito maior era a melhoria da sociedade.

Nesse sentido a arte opera a mimeses como algo que "organiza as maneiras de fazer, ver e julgar", sem submeter, como no regime ético, o objeto à semelhança ${ }^{43}$. Trata-se de um modo de visibilidade das artes que foi inaugurado nesse processo e se desenvolveu com a autonomização do campo

\footnotetext{
${ }^{40}$ BOURDIEU. Pierre. Economia das Trocas Simbólicas. São Paulo: Perspectiva, 2007. p.100.

${ }^{41}$ OSBORNE, Harold. op. cit. p.128, et seq.

42 Vasari foi responsável pela fundação da Escola de Desenho de Florença, fundada em 1554, que serviu de modelo para todas as Academias de Belas-Artes que se proliferaram por toda Europa nos dois séculos seguintes. ARGAN, Giulio Carlo. História da arte como história da cidade. Martins Fontes, São Paulo: 2005. p.24

${ }^{43}$ RANCIÈRE, Jacques. A partilha do sensível. São Paulo: EXO experimental org.; Ed. 34, 2005. p.24. O regime ético faz referência à antiguidade clássica, em que não há arte no sentido singular, e a mímeses é uma imitação do modelo de verdade.
} 
da arte, com a transformação da distribuição das maneiras de fazer e das ocupações sociais.

A função da mimesis tornou-se pragmática, principalmente, à medida que passou a identificar quais as artes capazes de produzir as imitações. Simultaneamente, passou a ser normativa, pois as imitações equivalem a gêneros específicos, enquanto promovem a avaliação de suas boas ou más qualidades. Assim, preserva a leitura aristotélica entre as regras de produção das artes e as leis da sensibilidade, da relação entre a poieseis, modos de fazer, e a aisthesis, modos de visualidade.

Porém, ao mesmo tempo, houve a gradativa substituição da razão pelo sentimento como critério fundamental para avaliação das belas-artes. Essa postura estava fundamentada na convicção dos críticos de que a arte e a literatura não deveriam ser julgadas pelos cânones clássicos, mas pelas propriedades capazes de atrair homens de sensibilidade requintada e cultivada $^{44}$. Depreende-se dessa proposição uma ideia de educação do gosto e da educação estética pensada como um instrumento a serviço do indivíduo e reconhecida em sua função social.

A partir do século XVIII, as instâncias de autonomização do campo da arte começaram a se multiplicar através das academias e dos salões. No entanto, do ponto de vista estético, a beleza artística se mantinha na condição de inferioridade em relação à beleza natural, cuja avaliação partia dos referenciais proporcionados pela natureza. Kant, considerado o fundador da estética moderna, endossou essa proposição ao destacar sua preferência pela beleza natural diante das belezas da arte, ao afirmar que a arte nunca se libertou totalmente empecilhos do naturalismo tradicional ${ }^{45}$.

De certa maneira, essa questão está ligada a uma importante mudança no lugar da beleza e na formação do gosto, no que concerne à relação do homem com a natureza e a arte. O que é belo, seja natural ou artístico, não mais estaria submetido a um ideal transcendente que se traduz na imanência do objeto, como

\footnotetext{
${ }^{44}$ OSBORNE, Harald. op. cit, loc.cit.

${ }^{45}$ É importante destacar que a contribuição de Kant para estética moderna foi importantíssima, principalmente em sua percepção que o campo estético não se esgotava com o Belo. Para Kant aquilo que era chamado de beleza apresentava duas facetas distintas: O Belo e o sublime. Se o belo, para ele era uma sensação desinteressada, o Sublime seria um sentimento estético misturado de sensações agradáveis e de terror, e experimentado contra o interesse dos sentidos.
} 
na formulação platônica. Ou mesmo nas propriedades harmoniosas do objeto como nas afirmativas aristotélicas ${ }^{46}$. A beleza passou a ser entendida como uma capacidade das faculdades humanas, em sua relação com o ambiente natural e cultural.

A partir dessa alternância dos valores que passaram a compor o olhar do homem sobre a natureza, arte e a cultura, também se tornaram evidenciados processos de distinção social. Isso porque a própria condição de imanência transfere-se para a alma e o espírito do homem de bom gosto, que tenha condição intelectual de "aquilatar obras de belas artes com a máxima correção e requinte" 47 . Soma-se a essa orientação, no que concerne ao campo da arte, a ideia de um dom natural do artista. Para esse autor o "gênio" é um talento inato e o cidadão comum não é capaz de desenvolver as mesmas faculdades.

Apesar de Kant abrir espaço para as reflexões que se tornaram fundamentais para os estudos da estética tradicional e contribuir para a autonomia da arte, no que se refere aos seus conhecimentos específicos, suas proposições argumentaram em favor da dicotomia entre razão e sensibilidade, além de enfatizar a ideia do deslocamento da figura do artista para um lugar diferente das pessoas comuns. Tal perspectiva se destaca no valor atribuído pelo filósofo às belas artes, colocando a poesia num lugar de destaque em função de sua capacidade relacional com o mundo do entendimento racional.

\begin{abstract}
Entre todas as artes a poesia (que deve sua origem quase totalmente ao gênio e é a que menos quer ser guiada por prescrição ou exemplos) ocupa a posição mais elevada. Ela alarga o ânimo pelo fato de ele pôr em liberdade a faculdade da imaginação e de oferecer dentro dos limites de um conceito dado sob a multiplicidade ilimitada de formas possíveis com ele, aquela que conecta a sua apresentação com uma profusão de pensamentos .... Ela joga a aparência que ela produz à vontade, sem, contudo, enganar através disso; pois ela declara a sua própria ocupação como simples jogo, que, no entanto, pode ser utilizado a fins pelo entendimento ${ }^{48}$.
\end{abstract}

As questões colocadas por Thierry de Duve, mostram que partir do pensamento de Kant foi sedimentada a base para separar a filosofia do encargo

${ }^{46}$ A beleza como propriedade dos objetos é derivada das formulações teóricas de Platão e Aristóteles. Porém, para Platão a beleza do objeto está relacionada a um plano ideal, enquanto para Aristóteles é uma qualidade física dos objetos. Essa ideia persiste até a orientação kantiana de que a beleza é construída pelo espírito do contemplador. SUASSUNA. Ariano. Iniciação à estética. Editora José Olympio. São Paulo, 2004. p.79.

${ }^{47}$ KANT, Immanuel. Crítica da Faculdade do Juízo. Trad. Valério Rohden e Antônio Marques, Rio de Janeiro: Forense Universitária, 2008. p.174.

48 Idem. p. 171. 
da metafísica, em especial da explicação dos elementos da transcendência. Ao mesmo tempo, à arte foi atribuída uma condição de espiritualidade, já que o gênio, o artista comunica essa transcendência na obra de arte bela. Essa transcendência não pode ser conhecida ou definida pelo conceito aplicado na experiência empírica e se traduz numa relação livre entre imaginação e razão. Dessa forma, nos contornos que envolvem as faculdades humanas, as operações entre a sensação e a capacidade racional não comportariam a consumação da experiência ${ }^{49}$.

A experiência estética não aparece na obra de Kant como uma cognição inferior e, tampouco, como processo que visa ao conhecimento, mas sim, como uma experiência que começa e termina na satisfação que os objetos provocam. Em sua obra, no que concerne aos aspectos formativos, a modalidade cognitiva, referente ao conhecimento intelectual; a prática, relativa aos fins morais que 0 homem procura na vida; bem como a experiência estética, que se fundamenta na intuição, no sentimento dos objetos que dão prazer e refletem uma atitude contemplativa de caráter desinteressado. A atualidade desse pensamento está na evidência e nas formas pelas quais essas concepções ainda nutrem 0 pensamento educacional no campo da arte.

Gadamer, ao tratar dessa questão, discorre sobre as consequências negativas da convicção kantiana ${ }^{50}$, principalmente no contexto atual, ao afirmar que o modo de ser do próprio objeto de arte "ganha o seu verdadeiro ser ao transformar-se em experiência que transforma" ${ }^{51}$. Para o autor, a arte não provoca apenas um prazer subjetivo que se encerra nele mesmo, mas oferece a possibilidade de uma nova compreensão. A experiência com a arte é capaz de mostrar algo sobre cada um dos sujeitos e transformar a maneira de relacionar com o meio.

${ }^{49}$ Em sua obra, Dewey traz um diálogo profícuo com a obra kantiana. Como um filósofo e educador, que trabalha tensão entre dois conceitos supostamente opostos, a fim de lhes dar uma unidade, ou síntese, busca diluir a dicotomia kantiana pelo equilíbrio dos procedimentos práticos empíricos e intelectuais. DEWEY, John. Arte como experiência. Martins Fontes, SP. 2010, p.114. 50 Embora Kant tenha se referido à educação como uma arte, a educação estética, em suas obras, não é devidamente acionada. Seu "idealismo" concebe a educação como arte da humanidade a ser aperfeiçoada por várias gerações e na prática educativa a subordinação ao dever, ao formalismo do imperativo categórico, não deixa o espaço devido para a ação estética. ZATTI, Vicente. Autonomia e educação em Immanuel Kant e Paulo Freire. Porto Alegre. EDIPUCRS, 2007. p.73.

51 GADAMER, Hans-George. Verdade e método - Traços fundamentais de uma hermenêutica filosófica. Ed. Vozes: Petrópolis, RJ, 2005. p.154 
O conceito de prazer desinteressado foi se tornando progressivamente acentuado e a relação de fruição deixou de estar ligada à ideia de finalidade da arte, para se ligar a uma classe de artefatos fabricados para contemplação e o prazer estético. Orientação que contribuiu para um gradativo desligamento da arte em relação ao seu propósito moral na sociedade.

Ao mesmo tempo em que a racionalização das coisas do mundo foi se consolidando, também foi crescendo no campo da arte uma resposta à autoridade da razão e da regra. Termos como sentimento, imaginação, emoção, impressão e sensibilidade passaram a ser as palavras de ordem das novas tendências nesse meio. Tendências que se consolidaram com o Romantismo, influenciaram posteriormente a arte moderna e tiveram o conceito de expressão como centro da ação poética.

Essa leitura promoveu um enfrentamento em relação à passividade empirista, enfatizou o papel da imaginação, sobre ou em acréscimo à razão, bem como promoveu a distinção entre o útil e o belo. O que contribuiu para que se consolidasse a noção da arte como ação individual advinda da sensibilidade do artista como gênio criador independente, e a ideia de auto expressão que influenciou, substancialmente, as ações educativas na modernidade no contexto brasileiro.

Thierry de Duve faz uma manobra reflexiva que permite ao leitor adentrar ao contemporâneo, sem perder de vista esses movimentos históricos. Subtrai do julgamento estético kantiano, a alternância entre as categorias do prazer e do desprazer. Na passagem da abordagem clássica (isto é belo) para a moderna (isto é arte), chega à conclusão que, de um a outro regime, existe uma cessação radical das convenções artísticas, tornando-se inviável a possibilidade de exercer um julgamento estético comparativo ${ }^{52}$.

De certa forma, o autor expressa a impossibilidade de uma categoria universal na qual se possa fundamentar o juízo estético comparativo em relação à arte, principalmente aquela produzida a partir da segunda metade do século XX. Mas, se não é possível compreender a produção artística contemporânea por meio de propriedades comuns, formais ou conceituais, como problematizala no processo de ensino e aprendizagem?

${ }^{52}$ DUVE, Thierry de. Cinco reflexões sobre o julgamento estético. In:Revista Porto Alegre, V16, n.27, 2009. 
O ponto de partida talvez esteja na própria forma, agora tratada como imagem. Cabe inquirir, então, o conceito de imagem, não como uma categoria de objetos cujas semelhanças ou dessemelhanças podem sustentar uma classificação de gêneros ou estilos, ou como algo que se constitui na formação de um ethos com a comunidade ${ }^{53}$, mas como a identificação da arte no singular, que a afasta de qualquer sentido comunitário determinado e, concomitantemente, de qualquer pressuposição artística, "de toda a regra específica, de toda a hierarquia dos sujeitos, dos géneros e das artes" ${ }^{54}$. Não deixando, porém, de the reconhecer uma esfera específica de experiência. $O$ argumento, aqui, está sustentado na conceituação de Jacques Rancière, de um regime estético, em que a arte se liberta da condição de artes e de belas-artes para ser definida por si própria ${ }^{55}$.

Esta definição permite, para o pensamento pedagógico, a abordagem do fenômeno imagético e, por conseguinte, da própria arte, como uma característica de toda experiência, e das práticas artísticas conectadas à constituição das formas de vida, da coletividade, mas sem um destino definido. Esse sensível heterogêneo da arte contemporânea, que se amalgama, de maneira indeterminada à vida cotidiana, permite a amplitude dos sensórios e seus endereçamentos - faturas. A própria função da arte/imagem passa a cumprir o papel de impor-se como uma realidade não separada dos modos de existência, mas como constituinte das suas várias maneiras de ser.

Nesse sentido, ao pensar as práticas artísticas e sua relação com o julgamento estético no processo educacional torna-se essencial desfazer 0 engessamento promovido pelas doutrinas filosóficas. Adicionalmente, cabe destituir os cânones que buscam sedimentar os trabalhos da arte sob a égide de uma ontologia das imagens, baseada em critérios de valor universais.

\footnotetext{
${ }^{53}$ As definições se reportam aos conceitos de regime ético e representativo da arte, cujas características podem ser associadas ao período clássico grego em que as imagens reportavam à verdade e aos seus usos e funções sociais (regime ético); e as belas-artes em que a função da mimesis é programática e normativa. RANCIĖRE, Jacques - Le partage du sensible: esthétique et politique. Paris: La fabrique éditions, 2000, p.31

54 Idem.

55 Há nesta afirmativa um sentido de autonomia da arte, que não pode ser associada às transformações nas práticas artística que conduziram à uma postura anti-mimética, e à conquista da forma pura. A autonomia da arte explica-se, antes, por uma desidentificação generalizada que desativa os princípios de diferenciação entre as artes, que entre os domínios da arte e da nãoarte.
} 
Para Rancière, "a identificação das práticas artísticas sempre derivou de uma inteligibilidade que as vincula a outras esferas da experiência" ${ }^{56}$, o que comunga com as proposições de Dewey de que a forma/imagem

\begin{abstract}
... não se encontra exclusivamente nos objetos rotulados como obras de arte [...] sempre que a percepção não é embotada nem pervertida, há uma tendência inevitável a dispor os eventos e os objetos tendo referencial nas exigências da percepção completa e unificada. A forma é uma característica de toda experiência, que é una. A forma pode então ser definida como a operação das forças que levam à sua realização integral da experiência de um evento, objeto, cena e situação ${ }^{57}$.
\end{abstract}

Dewey afirma que a natureza da forma/imagem é idêntica aos processos pelos quais se efetua a condução da experiência à sua realização. O que torna possível pensar nas práticas artísticas como um análogo do conceito de forma/imagem e, como um eixo no qual as práticas pedagógicas podem articular conteúdos (elementos não discursivos, ações e afetos), elementos discursivos e as alteridades, em suas potências de mobilizar o processo formativo. Nesse contexto, o termo análogo refere-se a algo que desenvolve as mesmas funções, embora possua origens e estruturas distintas.

Soma-se a isso o aspecto territorial, que assume centralidade na arte contemporânea, como a forma em si de conexão das dimensões supracitadas. O conceito de agenciamento, tal como proposto por Deleuze e Guattari torna-se substancial para o trânsito proposto. O agenciamento, como um acontecimento multidimensional, antes de qualquer coisa, é territorial, um acontecimento que pressupõe a territorialidade que deve ser descoberta ${ }^{58}$.

A natureza política e social de Cildo Meireles; os labirintos de Hélio Oiticica, os bichos de Lygia Clark; o Museu da Arte Útil, da artista cubana e professora Tania Bruguera; as cidades e os encontros de Lucimar Bello Frange; as Hortas e paisagens de Dália Rosenthal; a violência contemporânea na obra da artista mexicana Teresa Margolles e o coletivo SAMEFO (sigla que provém de Serviço Médico Forense); a natureza lúdica, mnemônica e corpórea de Stela Barbieri; as águas do recôncavo baiano de Viga Gordilho e as problematizações

\footnotetext{
${ }^{56}$ RANCIÈRE, Jacques. Le ressentiment anti-esthétique. Magazine Littéraire, n. 414, nov. 2002 , p. 19.

57 DEWEY, John. 2010. pp. 263-264.

58 HAESBAERT, Rogério. O mito da desterritorialização. Do fim dos territórios à multiterritorialidade. Rio de Janeiro. Bertrand Brasil, 2007. p. 125.
} 
ecológicas na poética de Hugo Fortes; as sincronicidades e simultaneidades multimídia da artista mineira Cinthia Marcele; as armas de Marcela Tiboni; a complexa e variada rede simbólica de clichês e mitos da sociedade chilena, que dignifica as expressões populares, de Bruna Truffa; as desigualdades sócio históricas da artista, pesquisadora e educadora Rosana Paulino; a abrangência da poética de Martin Sastre, que articula, ao mesmo tempo, a lógica econômica de mercado dos bens de luxo e os gestos culturais de seu país, são agenciamentos que trazem, para o ensino da arte, a necessidade de uma abordagem do conceito de imagem a partir dos modos de operar dos artistas.

Em uma lista que poderia se estender exponencialmente, cada uma dessas poéticas é um esforço rigoroso e persistente para evitar o reconhecimento do sujeito num real concebido como espelho, evitar o triunfo das certezas institucionais, que produzem o mundo como um encadeamento sucessivo de causas e efeitos, de meios e fins. São poéticas que examinam espaços e processos de comunicação, legados da história da arte com base em procedimentos estéticos que articulam as linguagens, o tempo, o espaço, a materialidade e imaterialidade do mundo, como um devir, um "tornar-se".

Nesse sentido, o próprio julgamento estético dessas poéticas não pode ser considerado a partir de uma característica objetiva, mas sim, pelo agrupamento de um conjunto de evidências que se encontram em suas linhas de fuga. Um processo que indica um caminho de saída para a vida como um critério de seleção de encontros, como um estado vibracional em que o estético e o ético atuam na mesma frequência, e só podem ser compreendidos como um acontecimento prático, como uma etologia que não passa pela moral, "como uma composição das velocidades e das lentidões, dos poderes de afetar e de ser afetado no plano da imanência"59.

Deleuze afirma que não há "território sem um vetor de saída do território, ou seja, desterritorialização ${ }^{60}$, sem, ao mesmo tempo, um esforço para se reterritorializar"61. Essa é a imagem do agenciamento: um constante deslocamento das práticas artísticas contemporâneas de um território a outro,

${ }^{59}$ DELEUZE, G. Espinosa e a Filosofia Prática. Tradução de Daniel Lins e Fabien Pascal Lins. São Paulo: Escuta, 2002. p.130.

${ }^{60}$ Deleuze afirma no vídeo feito por Parnet, que as palavras territorialização e desterritorialização foram invenções de Guatarri, durante as sessões de psicologia de grupo.www.

${ }^{61}$ Idem. Deleuze no vídeo “L'abécédaire de Gilles Deleuze”, filmado em 1988 por Claire Parnet. 
rompendo os limites disciplinares, percorrendo as linguagens, os meios e os modos para irromper e desconfigurar os aspectos duráveis da realidade.

Nos domínios da filosofia, a experiência estética está intimamente relacionada à ideia de forma ou imagem na arte e, obviamente, à uma relação entre sujeito (s) e objeto (s), em uma dinâmica em que há a prevalência do binômio gosto e beleza. Nesse movimento, em que a beleza não se apresenta como um conceito, mas como um sentimento em relação ao objeto, e o gosto como um julgamento subjetivo, a imagem emerge separada de qualquer atributo relacionado à práxis do artista, à sua coerência, ou não, nas maneiras de operar.

Essa limitação, que pode ser definida como contemplativa, informa sobre duas perspectivas. A primeira, que a imagem é apenas um meio para ascender ao conceito, à forma de mediação, a segunda, em sentido contrário, uma realidade que se oferece como apresentação sensível de uma ordem que representa a própria realidade que apresenta, dotada de um ser próprio, um outro.

Para reencontrar o sentido do termo estética, sua abrangência na produção contemporânea, bem como estabelecer o lugar da experiência da e com a arte, no campo educacional busca-se compreender o conceito de imagem e suas relações com as práticas artísticas. Vislumbra-se na tensão entre esses dois elementos um espaço conceitual e um modo de referência que trarão subsídios para as análises posteriores dos processos pedagógicos, que serão abordados nas análises do estudo de caso.

Destarte, é necessário compreender como esses sistemas de "visualidades, visibilidades, dizibilidades e representações"62, que se entrelaçam nas práticas artísticas, definem uma outra maneira de abordagem da imagem. Além disso, perceber como o processo de ensino e aprendizagem, pode vir a acrescentar uma outra orientação ao envolvimento transdisciplinar que envolve a arte. Assim, são discutidos no trabalho dos artistas Martin Sastre, Marcela Tiboni, Tania Bruguera, alguns elementos que possibilitam explicitar como os agenciamentos promovem o estético por meio de estratégias que articulam os

62 RANCIÈRE. Jacques. O destino das imagens. Trad. Mônica Costa Neto; Org, Tadeu Capistrano - Rio de Janeiro: Contraponto 2012. 
afectos evocando a imageria ${ }^{63}$, temporalidades e espaços e desestabilizam os aspectos do real no processo de encontro e partilha de saberes.

As investigações dos referidos artistas e educadores se dá em função de suas dessemelhanças. Sastre não é um educador e trabalha com arte não objectual, no entanto, dedica-se ao processo de formação e inserção de jovens artistas por meio de sua Fundação. Marcela Tiboni é uma artista objectual, performática, educadora, e tem uma empresa que desenvolve projetos de mediação, enquanto Bruguera, além de professora no ensino superior (Universidade Luav de Veneza - Itália), é uma das artistas contemporâneas com maior inserção no circuito internacional. O que une narrativas tão distintas é a maneira como suas poéticas carecem da marca do outro para disseminar suas potências. São três abordagens do estético que envolvem pessoas, processos e produtos que, em essência, trazem elementos para que se possa pensar na relação entre arte e educação em contextos, como meio de efetivação e perpetuação das experiências.

\subsection{El perfume de Pepe}

A experiência acontece quando se é lançado para fora do hábito. Este não $\operatorname{lugar}^{64}$ (desubjetivação-desterrritorialização) provoca a mobilização das referências que ativa o processo de reconfiguração das formas de conhecer. As imagens da arte trazem essa tensão necessária, o encontro com uma pré realidade (perceptos e sensações) que encontra resistências que podem ser superadas, quando há uma adaptação e uma reciprocidade entre o trabalho

\footnotetext{
${ }^{63}$ Embora o conceito de imageria já tenha sido definido, vale enfatizar que quando os termos forma ou imagem surgem no texto, se referem exclusivamente à arte e às práticas artísticas. Alguns campos de estudo, como a Cultura Visual, trazem grandes contribuições para ensino da arte, ao adotarem procedimentos de pesquisa que abordam os processos culturais, os costumes visuais. No entanto, há nessa abordagem a submissão da imagem ao texto, ou do sensível ao histórico. Imageria, então, refere-se a qualquer tipo de imagem, mas, que dentro dos modos de operar na arte, são destituídas do seu sentido no senso comum e requalificadas em um corpo semântico específico.

64 "Não lugar" refere-se ao espaço de passagem incapaz de dar forma a qualquer tipo de identidade. Trata-se de um processo de dessubjetivação que possibilita a reterritorialização promovida pelo encontro, pela partilha. O espaço que vem-a-ser. É importante destacar que o conceito não se confunde com o elaborado por Marc Auge, In: Le Sens des Autres, 1994, pg. 169. Para este autor o "não lugar" é definido como o espaço em que não há relação, mas semelhança e solidão.
} 
intelectual e a abertura sensível aos afectos ${ }^{65}$. Os devires que emanam e excedem as forças daqueles que os sentem. Pode-se dizer que os artistas distorcem a percepção, retiram a durabilidade do real e a multiplicam por meio de um complexo de sensações que dinamizam o campo ficcional. Isso é possível perceber nas proposições poéticas do jovem artista uruguaio Martin Sastre.

Nascido em Montevidéu, um dos fundadores do Movimento Sexy, um coletivo de artistas cujo foco está em aproximar a cultura midiática da arte, Sastre busca na linguagem videográfica (o que, por vezes, remete a trabalhos amadores), na produção de falsos documentários, reportagens e programas de Reality Show, as reflexões sobre a sociedade contemporânea, a indústria cultural e o processo de globalização. Indaga sobre o voyeurismo, a superexposição, a vigilância e, sobretudo, sobre as questões territoriais, que enfatizam as questões sensoriais, rompendo com os limites entre o publicitário, o corporativo e o estético, questões da arte pertinentes que não podem passar indiferentes à educação.

Flores, ervas daninhas colhidas de um quintal solene são matérias primas para a confecção de um perfume artesanal. Um vídeo "quase publicitário" anuncia o produto. Um homem, gradualmente se despe até ficar apenas com a roupa íntima, uma máscara e uma valise, entra na sede de um banco, e sobre a mesa de reuniões da instituição, dança e desliza em direção a um cofre, que depois de aberto, revela o produto, o "Perfume del Pepe".

O trabalho consiste em um vídeo, um perfume e um fundo para artistas contemporâneos não objectuais (Figuras 1 e 2). A primeira fase do trabalho foi a criação do vídeo "U do Uruguai" lançado no ano de 2012, no âmbito da Primeira Bienal de Montevidéu. Filmado na sede do Banco da República Oriental do Uruguai, o trabalho foi exposto na $55^{\mathrm{a}}$ Bienal de Veneza e leiloado por $50 \mathrm{mil}$ dólares. A exemplo do presidente uruguaio, que não recebia o seu salário integralmente, quando no exercício do poder, Sastre doou $90 \%$ do valor arrecadado para o fundo de artistas contemporâneos.

65 DEWEy, John. op. cit. p. 265; DELEUZE, G. Op. Cit. 1988. 

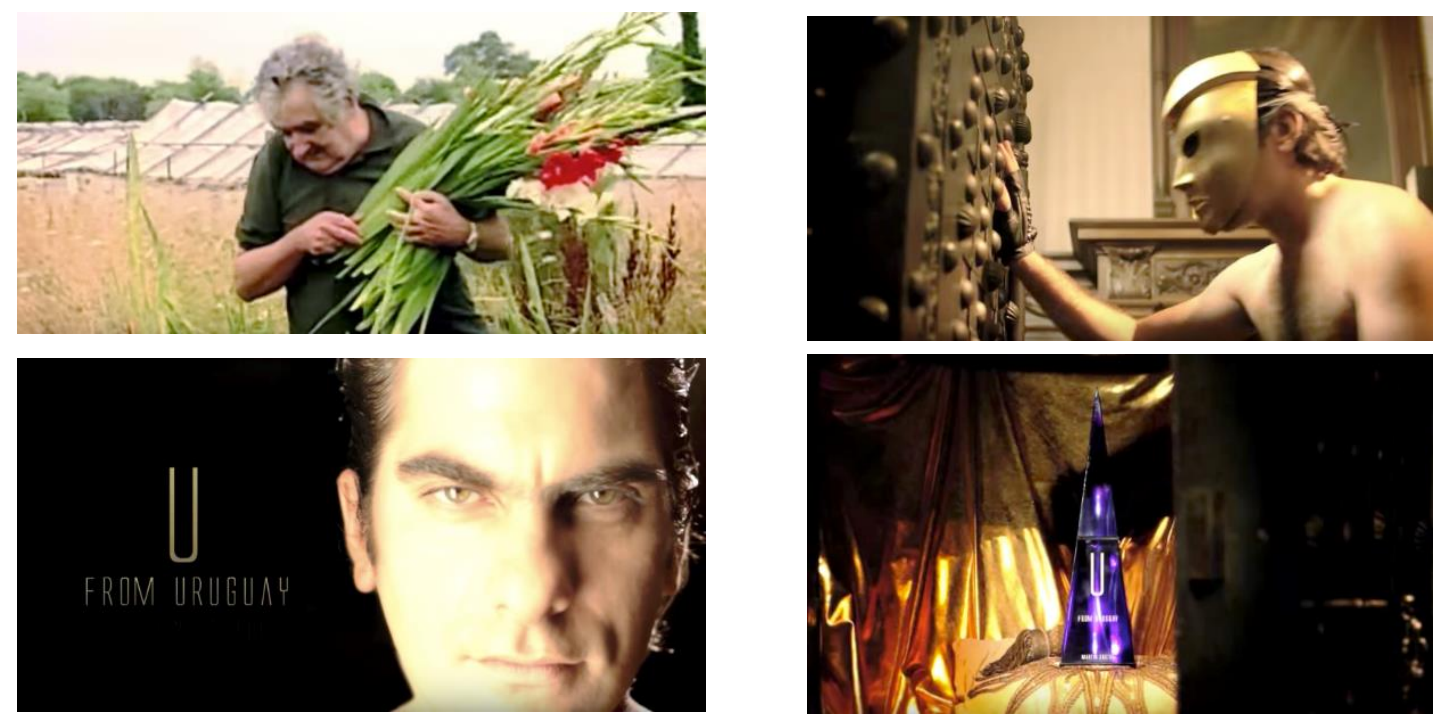

Figura 1: Conjunto de Fotogramas 01. Vídeo "Perfume del Pepe". Martin Sastre. Fonte: Fundação Martin Sastre. 2013 - Bienal de Montevidéu/ Bienal de Veneza.

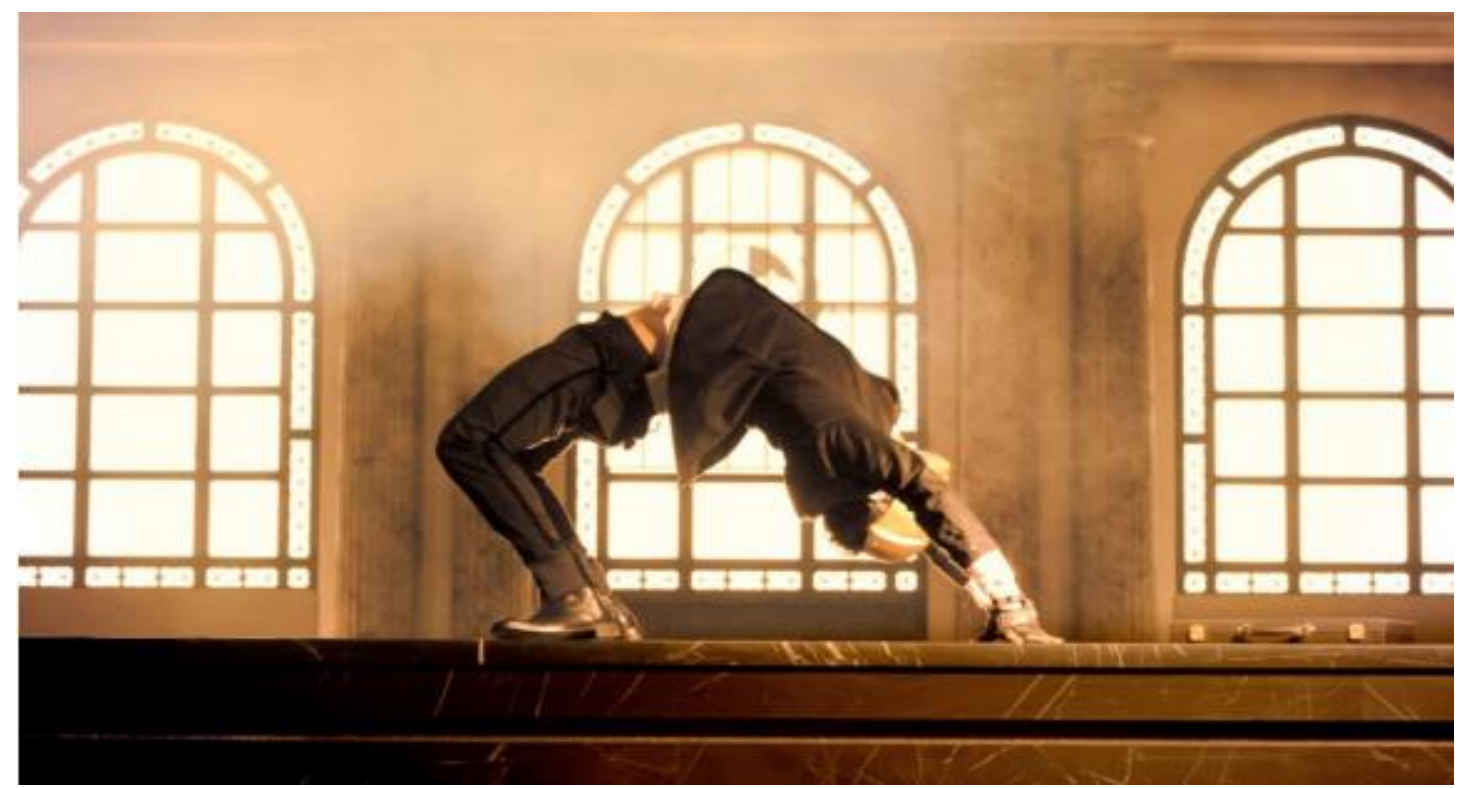

Figura 2: Conjunto de Fotogramas 01. Vídeo "Perfume del Pepe". Martin Sastre. Fonte: Fundação Martin Sastre. 2013 - Bienal de Montevidéu/ Bienal de Veneza.

O perfume foi desenvolvido em um momento posterior ao vídeo (depois do convite para participação na Bienal de Veneza), com ervas daninhas e flores ${ }^{66}$ cultivadas no quintal da residência, do então Presidente da República do

${ }^{66}$ Entre as ervas daninhas utilizada por Sastre está a "Chirca", que no Uruguai é considerada mato, porque não é utilizada para alimentar o gado, no entanto, produz m óleo que é utilizado para a confecção de perfumes na França. Fonte: Disponível em : http://www.archdaily.com.br/br/01-66525/bienal-de-veneza-2012-panavision-pavilhao-douruguai. Acessado em : 04/11/2013. 
Uruguai, José Alberto Mujica Cordano, um veterano ex-guerrilheiro Tupamaro, conhecido pelo seu desapego às formalidades. Sastre trabalha com o luxo e a essência das coisas, explicita a lógica do monopólio e dos mercados dos bens de luxo, envolve a simplicidade de Mujica e sua esposa Lucía Topolansk (parceiros na colheita), contrastando elementos simbólicos e a acessibilidade ao poder, leva os cheiros de um país pequeno a um dos espaços internacionais que representam o mainstream da arte.

Nas estratégias do artista há movimentos concomitantes de territorialização e desterritorialização. O agenciamento articulado em torno do conteúdo e da expressão traz a linguagem publicitária, a colheita simbólica, o cheiro de um lugar, uma instituição bancária, a um espaço consagrado da arte. Tudo é estruturado em uma composição singular, em uma forma que agrega objetos e atitudes, que de outra maneira seriam opacos, restritos aos seus territórios. O mundo sensorial se funde ao pensamento pela criação de uma nova experiência que abre fissuras no mundo comum, nos poderes e hierarquias constituídas.

Na poética de Sastre são identificáveis elementos significativos de uma metamorfose que se conecta às manobras duchampianas, bem como a movimentos distintos do modernismo, como o construtivismo russo, e o funcionalismo alemão, "partícipes da estética das máquinas, da fotomontagem e de outras maneiras de trabalhar a publicidade e propaganda, formam uma corrente que coincide e resulta dos ready-made"67. A título de exemplo, a Figura 3 rememora o trabalho de Rodchenko (1891-1956), artista que desenvolvia construções espaciais, suspensas por fios (Figura 3$)^{68}$.

67 Duve. Thierry de. Kant depois de Duchamp. In: Revista do Mestrado em História da Arte EBA. UFRJ, 1998. p.128.

68 NAKOV, Andrei Boris. "Notice Biographique". In TARABOUKINE, Nikolay. Le Dernier Tableau/ Du Chevalet à la Machine; Pour une Théorie de la Peinture/ Écrits sur l'art et l'histoire de l'art à l'époque du constructivisme russe. Presentés para A. B. Nakov, trad. du russe par Michel Pétris et Andrei B. Nakov. Paris, éditions Champ Libre, 1980, p. 19. 


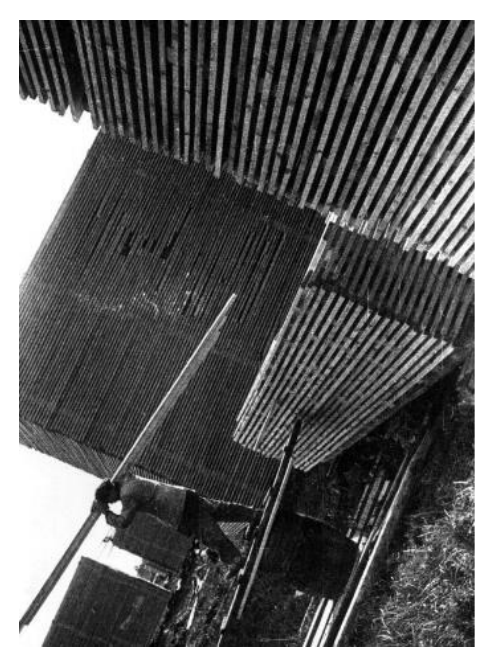

Figura 3: A. Rodchenko, Pilha de tábuas na madeireira de Vakhtan, 1930.

A questão, aqui, não pode ser tratada do ponto de vista de sua paternidade, mas como uma poética que estabelece um conjunto de procedimentos que ultrapassa a dicotomia histórica entre o conceitualismo e o formalismo na arte. Os processos se fundem aos produtos e imprimem a marca do outro em todos os seus deslocamentos. A amplitude, ressonâncias do trabalho, está em seus enunciados, seus alcances pragmáticos, seu impacto social, suas inscrições históricas, sua densidade narrativa e as suas dimensões éticas ${ }^{69}$.

Como se pode perceber, não há um predomínio da forma sobre a função, uma linha de pensamento iniciada com Kant e que sustenta um conceito de arte que estava relacionado à autonomia do estético. Uma forma de arte que só poderia ser avaliada pelos seus valores formais. O que ocorrem são manobras com determinadas formas, operações com significantes que promovem 0 enriquecimento dos sentidos. Constituem agenciamentos que ultrapassam as restrições da forma e ao se estenderem pelas as linhas de fuga, afetam e se deixam afetar por outros conteúdos, ampliando os significados da expressão e da experiência estética.

${ }^{69} \mathrm{~A}$ arte perdeu seus fundamentos metafísicos. In: entrevista com Ticio Escobar. Por Carolina Castro Joquera. 21/4/2014. Acessado em 12 de novembro de 2014. Disponível : www.blog.caroinc.net/sobre-limites-y-posibilidades-entrevista-aticio-escobar. Ticio Escobar é pesquisador, professor, crítico de arte, ensaísta e curador paraguaio. Suas pesquisas sobre a produção contemporânea nas artes visuais e arte indígena trazem elementos muito importantes para o contexto latino-americano. 
O trabalho de Sastre tem como foco ironizar a relação centro periferia, na produção contemporânea. Em que pese o artista não trabalhar com educação, sua crítica à atual organização sociopolítica mundial, a partir de uma ótica "latinocentrista", apresenta elementos essenciais para a compreensão das possibilidades que o espaço, em sua amplitude simbólica, tem para ser um eixo para as ações educativas.

Nos domínios da filosofia, a experiência estética está intimamente relacionada à ideia de forma ou imagem na arte e, obviamente, à uma relação entre sujeito (s) e objeto (s), em uma dinâmica em que há a prevalência do binômio gosto e beleza. Nesse movimento, em que a beleza não se apresenta como um conceito, mas como um sentimento em relação ao objeto, e o gosto como um julgamento subjetivo, a imagem emerge separada de qualquer atributo relacionado à práxis do artista, à sua coerência, ou não, nas maneiras de operar.

\subsection{Tato, cheiro, razão, sentimento, impotência, mobilidade}

Marcela Tiboni é uma jovem artista brasileira ${ }^{70}$. Iniciou seu percurso artístico questionando a expressão da pintura na contemporaneidade. Trabalha com vídeo-performance, fotografia e objetos. No entanto, o que chama a atenção em sua produção estética é o anacronismo. Um aspecto importante na produção contemporânea e, que de certa maneira, introduz uma questão que afeta, sobremaneira os educadores: a relação entre as técnicas e os materiais da tradição artística e o seu lugar nos modos de operar na arte contemporânea.

O que se define, aqui, como anacronismo, ao fazer referência ao trabalho de Tiboni, não diz respeito a um desencontro em que os valores e hábitos de diferentes períodos ou épocas são considerados como se fossem idênticos. Mas, sim, a uma condição prévia para um acontecimento ser ligado a diferentes tempos e espaços. Diz respeito ainda às condições e possibilidades desses acontecimentos incorporarem ao universo prático, do fazer, o trânsito entre

\footnotetext{
${ }^{70} \mathrm{~A}$ artista e formada em artes plásticas pela fundação Armando Álvares Penteado -FAAP- São Paulo, no ano de 2003, mestre em Estética e História da Arte pelo Museu de Arte Contemporânea da Universidade de São Paulo - Mac - USP, em 2009.
} 
essas duas dimensões, por meio de inquirições que perpassam os campos do pensamento, da materialidade, da imaterialidade, das técnicas e dos meios para a edificação das imagens.

Se, no moderno, o artista controlava suas condições de produção por meio de planejamentos, na maneira de operar com a forma e estrutura, contemporaneamente, passa a atuar com um agenciador, interferindo em situações complexas nas quais interage com outros agentes e não exerce o controle total, inclusive político, de seu trabalho ${ }^{71}$. Nesse sentido, as práticas artísticas contemporâneas, como se pode perceber na poética de Tiboni, incorporaram aos seus modos de operar a modernidade do mundo que é, segundo Gideens ${ }^{72}$, a própria constituição do contemporâneo, porque rompeu com o passado tradicional das práticas isoladas, mas não negou a tradição. 0 que sustenta a ideia de que, se antes vivia-se em um mundo tradicional, hoje vive-se em um mundo de tradições. Talvez isso explique a razão dessa orientação anacrônica ${ }^{73}$, inerente à essas práticas, que encontram resistências no campo pedagógico.

Em sua vídeo-performance "O Grito" (vídeo de 50 segundos), no ano 2003 (Figura 4), o foco do trabalho estava na imersão, no domínio da pintura de outras maneiras, que não pelo ofício de pintar. A artista bebe e vomita tinta, se deixa envolver com a matéria de um ofício secular e busca o diálogo com o expressionismo do norueguês Edvard Munch. Tiboni afirma que

\begin{abstract}
[...] ainda na faculdade, identifiquei-me com a pintura, mas logo percebi a incapacidade de realizar com as mãos aquilo que meus olhos eram capazes de captar. A fotografia surgiu como uma descoberta de linguagem, fazendo-me não só criar pinturas através das lentes como ainda experimentar a tinta, a tela, as expressões e os lugares com o meu próprio corpo, metade pictórico, metade fotográfico. A partir de tais descobertas, eu e meu trabalho tornamo-nos parceiros da pintura e seus grandes pintores. A fotografia me permite habitar telas, tocar personagens, passear no tempo, inventar diálogos e propor encontros ${ }^{74}$.
\end{abstract}

\footnotetext{
${ }^{71}$ ANDREOLI, Elisabetta, e SANTOS, Laymert Garcia dos. "Arte pública, cidade privada". In PEIXOTO, Nelson Brissac (org). Intervenções Urbanas: Arte/Cidade. São Paulo: Editora SENAC São Paulo, 2002.

72 GIDDENS, A. As consequências da modernidade. São Paulo, Unesp, 1991.

${ }^{73}$ RANCIÈRE. Jacques. Aisthesis. Scènes du régime esthétique de l'art. Paris: Galilée, 2011.

${ }^{74}$ MIYADA, P. Marcela Tiboni: Arsenal - Entrevista concedida a Paulo Miyada. Disponível em: http://goo.gl/TseogW Acesso em 15 de agosto de 2014.
} 

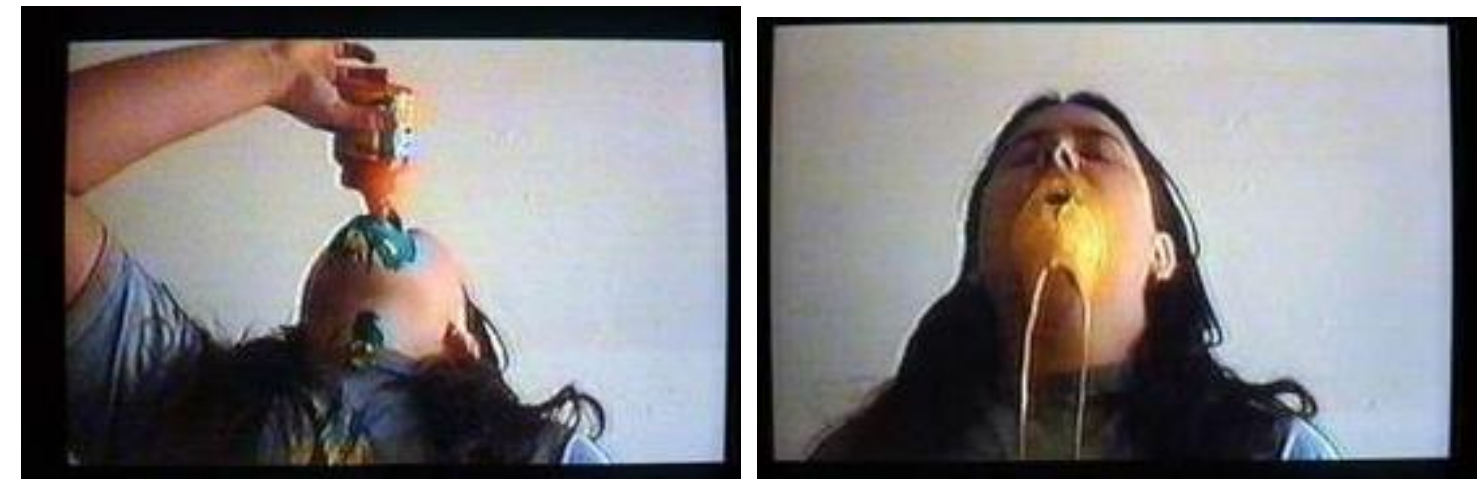

Figura 4: Fotogramas: vídeo-performance "O Grito", 2003, Paço das Artes, USP - SP. Fonte: http://migre.me/81IYB .

Os procedimentos de Tiboni provocam uma leitura que ultrapassa a forma clássica fundamentada em uma lógica linear de sucessão e possibilita compreender a maneira como as práticas artísticas contemporâneas articulam a horizontalidade da análise temporal (e exige dos receptores o mesmo). Apresenta a orientação anacrônica como "problema vertical da ordem do tempo na hierarquia dos seres. É um problema de partilha do tempo no sentido da parte que cabe a cada qual" 75 .

Hoje, seja qual for a sustentação teórica que faça referência ao trabalho de um artista, ela deve ser tratada pelo ensino da arte em sua relação com os modos de operar e pelos distintos modos de recepção que essas práticas propõem. O desafio prático é que, quando se faz uma abordagem sobre a produção artística atual, os conceitos, frequentemente, não seguem a mesma sincronia semântica. Os mesmos conceitos podem ser utilizados para designar significados diferentes e assim estarem presentes em tempos distintos.

Considerando dessa maneira, os conceitos derivados das teorias da arte com os quais trabalha-se no universo prático do ensino da arte podem sim, fazer sentido. No entanto, não seria prudente assumi-los como teorias e ou conceitos que visam estabelecer condições necessárias e suficientes ou essências comuns, mas que sejam capazes de espelhar dimensões importantes da produção estética no campo educacional. Compreendendo as relações

\footnotetext{
${ }^{75}$ RANCIÈRE, Jacques. op. cit. p.23.
} 
sistemáticas existentes entre as abordagens conceituais e destacando os aspectos que podem ser problematizados na realidade dos educandos.

$\mathrm{Na}$ concepção de Rancière, no que se refere à essa produção estética, não há uma hierarquia da ordem do tempo, ou uma determinação no que diz respeito a cada período que o separa de outro. Há, sim, um processo laboral dos sujeitos que, em relação ao seu próprio tempo, atendem às demandas e pressões sociais e culturais que são encarnadas em sua consciência e seu modo de agir.

A questão central é que a narrativa historiográfica, fundamentalmente, a moderna, não busca apenas encadear acontecimentos sucessivos, mas edificar um "todo significante", como definiu Gadamer ${ }^{76}$ ao tratar da consciência cultural no Ocidente. O que é, particularmente, válido no que tange à ideia da existência de "uma arte para todos", uma utopia que surgiu na Grécia clássica e persistiu na modernidade das culturas colonizadas como negação da pluralidade cultural e estética.

Tomando a poética de Tiboni como referência para o diálogo com essa concepção, percebe-se a insustentabilidade da ideia de uma verdade absoluta, que possa ser generalizada a partir da experiência particular e histórica. O que abrange, tanto aquilo que envolve a ordem do fazer (que obviamente carece do domínio dos meios), como seus fundamentos, que envolve a maneira como o processo criativo possibilita conceber e abordar um determinado aspecto da realidade, por meio do pensamento.

Segue-se dessa distinção, ou visão pré-concebida, uma importante consequência, que confunde as honestas teleologias ${ }^{77}$ da conquista das verdades e da dicção concisa e controlada da educação, contra as fantasias da ficção poética. Nessa óptica, a promoção da história como discurso verdadeiro passa pela sua capacidade de tornar-se semelhante à poesia, de imitar por sua própria conta a potência da generalidade poética. Isso, para que seja exequível desfazer o nó do tempo, com o possível e com a eternidade. Em contraponto,

\footnotetext{
${ }^{76}$ GADAMER, H.G. La actualidad de lo bello. El arte como juego, símbolo y fiesta. Ediciones Paidós Iberica, S.A. 1991. Barcelona. p. 36.

77 Doutrina que identifica a presença de metas, fins ou objetivos guiando a natureza e a humanidade. Formulada por Aristóteles esta teoria aparece na concepção Hegeliana como um processo histórico da humanidade. MORA, José Ferrater. Dicionário de Filosofia. São Paulo: Martins Fontes, 2001.
} 
Rancière afirma que o conceito tradicional de anacronismo é anti-histórico porque vela as condições mesmas de toda historicidade.

Ou seja, há história à medida que os homens não se 'assemelham' ao seu tempo, com a linha de temporalidade que os coloca em seus lugares impondoIhes fazer do seu tempo este ou aquele 'emprego'. Mas, essa ruptura apenas se torna viável pela possibilidade de articular essa linha de temporalidades a outras, pela "multiplicidade de linhas de temporalidades presentes em um tempo"78. Como em "Meus Mitos", exposição de Marcela Tiboni, composta por onze obras, fotografias e objetos, no ano de 2010, na galeria nuVEM (Figuras 5 e 6).

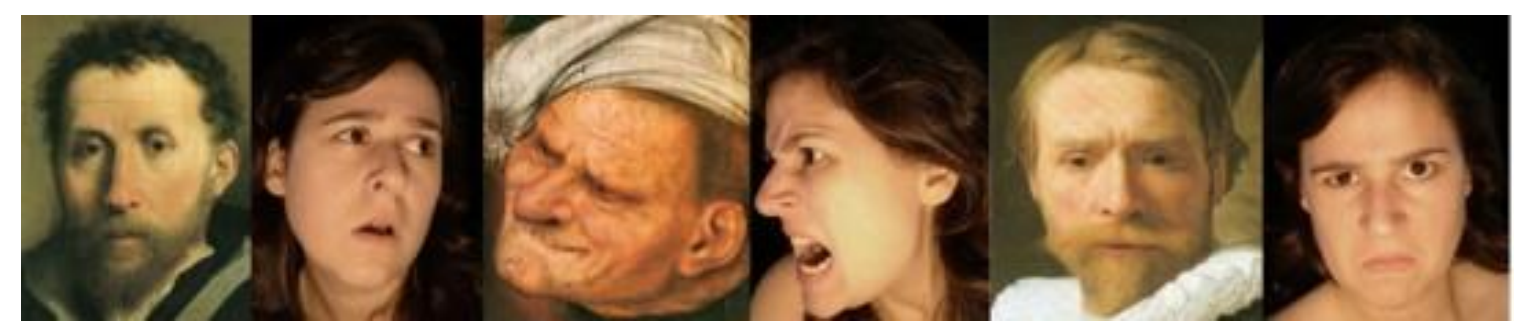

Figura 5. Exposição "Meus Mitos" - Marcela Tiboni. Galeria nuVEM, 2010. Fonte: galerianuvem.com.br
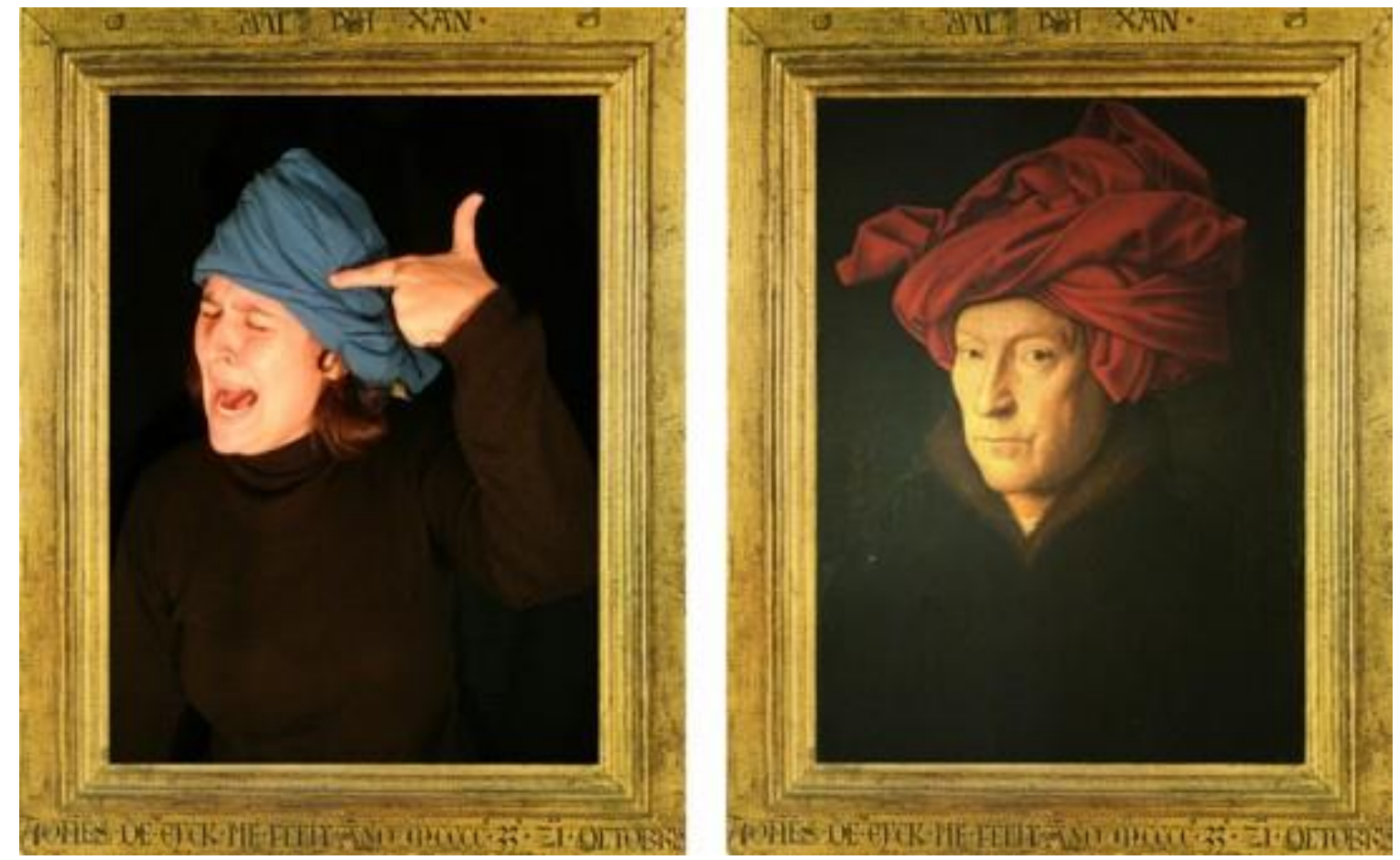

Figura 6. Exposição "Meus Mitos" - Marcela Tiboni. Galeria nuVEM, 2010. Fonte: galerianuvem.com.br

${ }^{78}$ RANCIÈRE, Jaccques, op. cit., loc. cit. 
Logo, existe história porque os tempos se convergem e se distanciam, se misturam, se entrecruzam. Pensar essa possibilidade parece um passo importante para romper com a caracterização do tempo, do espaço e das dimensões que implicam as abordagens educativas, principalmente, no que se refere às suas imersões e busca de referências no universo imagético da história da arte.

Tiboni usa o próprio corpo como veículo semântico que possibilita 0 acesso à linguagem plástica, e abre os aspectos duráveis das experiências que se conectam, também, às imagens da escrita literária. O corpo é suporte, meio e mensagem em um processo em que o personagem encarna e integra linguagens sem perder o vínculo referencial com a tradição, na abordagem de questões latentes da contemporaneidade, como nos estudos para desenho de corpo feminino e Jônico sob rosto feminino (Figura 7)

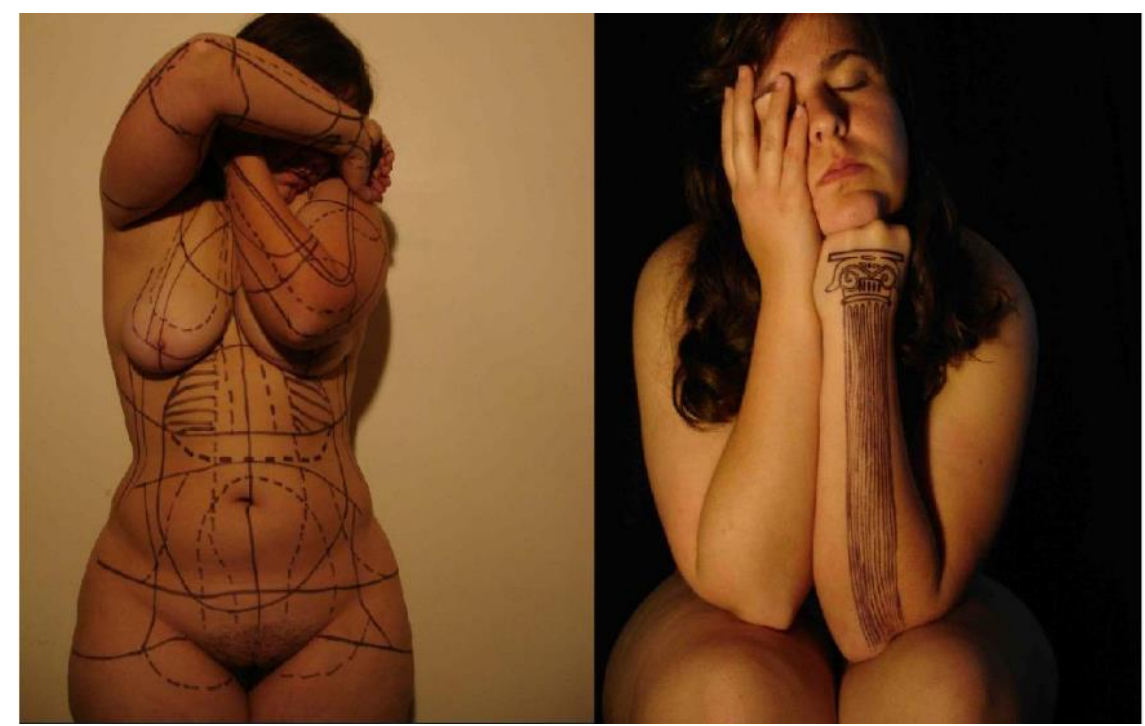

Figura 7. Estudo para desenho do corpo feminino/ Jônico sob rosto feminino - Marcela Tiboni. 2010. Fonte: www.performatus.net (erevista performatus)

Segundo a artista e educadora, no início de sua trajetória, o processo de criação de seus trabalhos "partia de alguma frase ou conceito específico de suas leituras, o que gerava um título, que promovia uma ideia de imagem para só então iniciar seu processo de realização". No entanto, esse processo de racionalização era dialetizado em seu modo de realização. "Era sempre essencial - $\mathrm{e}$ isso pode ser visto internamente na obra - uma experiência direta 
com o material discutido no trabalho, que sempre se reportava à história da arte que temos acesso"79.

Em sua produção mais recente, Tiboni enfatiza o intercâmbio entre os aspectos estéticos e a dinâmica da experiência cotidiana com a assimilação violência (Figuras 8 e 9). Ela afirma que está trabalhando com

[...] uma imagem que é reconhecível praticamente no mundo inteiro, talvez uma tribo ou outra não reconheça esse objeto. Quando eu exponho dentro ou fora do Brasil as pessoas reconhecem rapidamente e sabem como funciona aquilo, sabem que é um objeto feito para encaixar na mão, então tem ali um apelo estético muito forte. As pessoas sendo a favor ou contra elas querem pegar e tem esse fetiche. Isso me interessa, criar um fetiche coletivo dentro do trabalho. Aquilo parece um brinquedo, parece que tem potencial de violência. As pessoas tem esse prazer e esse fetiche por esse objeto. Então, como questão estética isso é extremamente importante no meu trabalho ${ }^{80}$

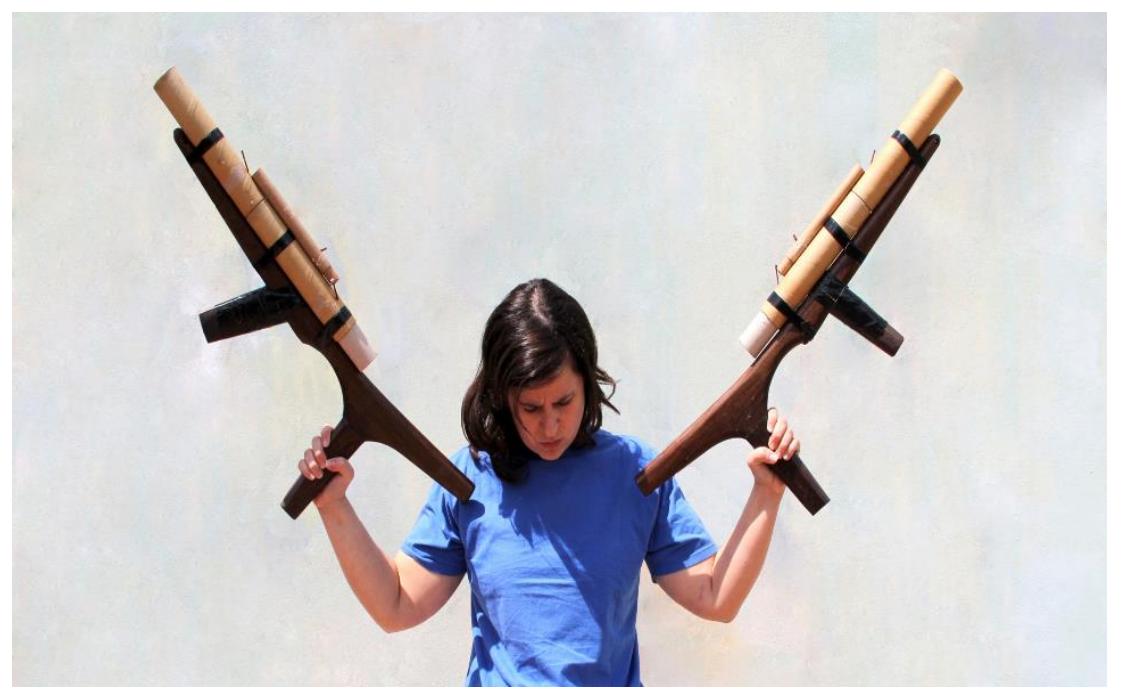

Figura 8. Arsenal, 2014 - Marcela Tiboni. IN: Revista Performatus. Fonte: www.performatus.net.

79 Tiboni, Marcela. In: Marcondes, Renan. Texto escrito a partir da entrevista realizada em 05 de agosto de 2014, na Galeria de Arte (São Paulo). Fonte: http://performatus.net/perfil-de-artista/asarmas-de-marcela-tiboni/ Acessado em 05/06/2015.

80 Tiboni, Marcela. Entrevista concedia a Carlos Weiner M. de Souza em 3/12/2016. 


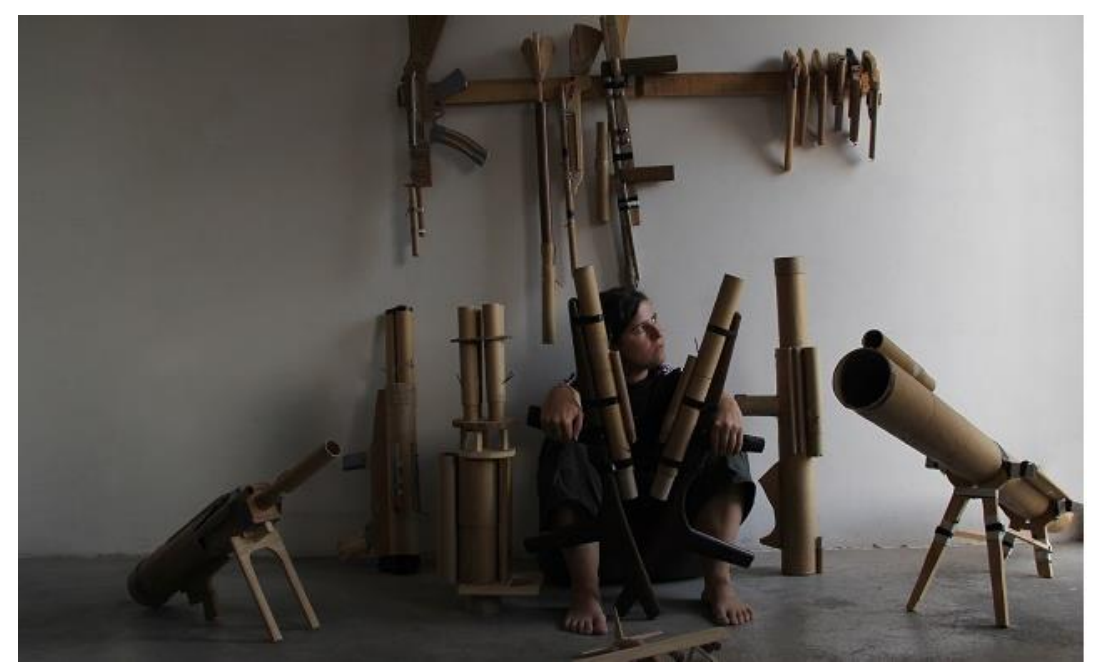

Figura 9. Arsenal, 2014 - Marcela Tiboni. Fonte: www.cultrafm.cmais.br (Central Galeria de Arte.

O mais instigante neste trabalho está na maneira como a artista promove o encontro discordante das percepções. Tiboni reside em uma região da cidade de São Paulo bastante militarizada, onde existem vários batalhões e o presídio do Carandirú. Suas armas são fruto de um rigoroso trabalho de marcenaria, no qual são necessários o domínio dos fundamentos que envolvem o desenho como um elemento projectual. No entanto, esses objetos apenas assumem sua condição final nas possíveis manipulações do público, no processo interativo.

Não são armas de brinquedo, mesmo que remetam à memória das brincadeiras de criança. Todos os artefatos são munidos de pólvora e há o risco de um uso inadequado por parte do público, que se torna ativo nas escolhas, assumindo a condição de personagem principal em contexto. Não há, nesse sentido, uma relação de culto ao objeto, uma perspectiva contemplativa, mas o envolvimento que se define pela ação consequente ou não do sujeito. As contradições expressas nas ações e/ou sentimentos em relação a violência são responsáveis por mobilizar a experiência.

No processo de mediação, feito pela própria artista, essas questões estão colocadas. A identificação de algo que faz parte do mundo no senso comum; as discordâncias sobre seus usos; o contexto em que as experiências carecem da marca do outro para se efetivarem no campo sensível e do pensamento. São estratégias de agenciamentos típicas das práticas artísticas contemporâneas que, mesmo pelo caminho objectual e, em um espaço institucional, articulam 
uma maneira de promover dissensos e problematizar o que fica escondido sob o manto da realidade naturalizada.

Como se pode perceber, as práticas artísticas de Tiboni evocam e fazem um manuseamento direto da realidade tangível a partir de quatro dimensões no âmbito da experiência com as imagens: a material, a contextual, a social e a estética. Cada qual, o sentido físico e palpável da realidade, a dimensão espacial e vivencial, a produção do sentido social como algo criado pelos sujeitos e correspondente ao campo ideológico, são convertidos pela ação estética que afeta a práxis social.

\subsection{A arte útil: agenciamentos coletivos}

Um dos indícios mais significativos da metamorfose pela qual a arte vem passando, está na forma como alguns artistas e educadores estabelecem suas estratégias de envolvimento com o público, nas maneiras como têm articulado imaginários, ideias, práticas, modos de vida e objetos, novas formas de intercâmbio que a tradição não permitia. Mas a arte pode ser um meio para imaginar, criar e implementar resultados socialmente benéficos? A pergunta formulada pela artista e educadora cubana Tania Bruguera ${ }^{81}$, coloca em pauta a necessidade de ressignificar a experiência com a arte, e aponta um caminho que requer dos atores envolvidos com o campo da educação outra relação de participação e comprometimento.

Laddaga ${ }^{82}$ afirma que há uma mudança de cultura nas artes, comparável em sua extensão e profundidade, à transição que ocorreu entre os finais do século XVIII e meados do XIX. Na modernidade estética, o conjunto articulado de teorias explícitas e saberes tácitos, instituições e rituais, formas de objetividade e práticas, se organizava em torno das práticas baseadas em

\footnotetext{
${ }^{81}$ BISHOP, Claire. "artificial hells: participatory art and the politics of spectatorship", chapter 9 - in: 'pedagogic projects:' how do you bring a classroom to life as if it were a work of art ', i.arte of conduct, ed Verso?. July 17, 2012. Brooklyn, new york, united states (fig.) pp. 241-250

82 LADDAGA, Reinaldo. Estética da emergência: a formação da outra cultura das artes. Tradução Magda Lopes - São Paulo: Martins Fontes, 2012. p.09.
} 
objetos, sua circulação e apreciação no âmbito institucional, passou a se organizar e se disseminar por meio de outras linhas força.

Essa transformação, que se situa nos limites dentre uma ideia de instrumentalização ou não da arte, motiva um debate acirrado, principalmente, após os anos de 1990. Como aponta Cesar ${ }^{83}$, um momento em que as práticas artísticas contextuais, que dão destaque às relações sociais, começaram a ganhar corpo na arte e, por conseguinte no campo educacional ${ }^{84}$. Exemplos desse fenômeno, hoje, podem ser observados de uma maneira já consolidada, por meio das ações e estratégias de grupos que comportam artistas e educadores, cujas denominações dão os contornos do que chamamos de coletivos de arte, ativismo, arte comunitária ou participativa, entre outros tantos termos.

O trabalho da artista e educadora cubana Tania Bruguera está inserido nessa orientação, que aborda a arte como uma experiência social, o que permite pensar sobre essas maneiras de abordar a atividade criativa e seus aspectos políticos e éticos, em uma estética ampliada no processo educacional em arte. Bruguera nasceu na cidade de Havana, Cuba, e atualmente vive e trabalha entre a sua cidade natal e a cidade de Illinois, em Chicago, nos Estados Unidos. Seu trabalho de investigação está nas maneiras pelas quais a arte pode encontrar a tangência com a vida cotidiana. Materializada na performance e nas instalações, trata o aspecto estético em sua dimensão social e coloca no centro de seu processo criativo questões que trazem incertezas produtivas para as reflexões que se equilibravam sobre um consenso aparente.

Há mais de duas décadas, a artista desenvolve trabalhos de caráter político, por meio dos quais concebeu os termos "Cátedra Arte e Conduta" e "Arte útil"85. O primeiro se refere ao projeto apresentado como alternativa de formação

${ }^{83}$ CESAR. Marisa Flórido. Como se existisse a Humanidade. In: Revista do Programa de PósGraduação em Artes Visuais EBA - UFRJ. Ano 14,n. 15, p.17-25, 2007.

${ }^{84}$ É importante destacar que neste período a professora e pesquisadora Ana Mae Barbosa formulou para o contexto nacional a Abordagem Triangular. A proposição, que se articula por meio da relação entre experimentação, codificação e informação, propõe para o ensino da arte três ações básicas: a leitura dos trabalhos da arte, em que a obra tem preponderância no processo de interpretação; o fazer; e a contextualização, que segundo Rizzi abre o espaço da interdisciplinaridade no processo de ensino e aprendizagem. Rizzi, Maria Christina de Souza Lima. Reflexões sobre a Abordagem de Ensino da Arte. In: Barbosa, Ana Mae (org.) Ensino da arte, memória e história. São Paulo: Perspectiva, 2008.

${ }^{85}$ BRUGUERA, Tania. TANIA BRUGUERA. Cátedra Arte de Conducta. Glosario, s/d. Disponível em: http://www.taniabruguera.com/cms/492-1- Ctedra+Arte+de+Conducta.htm . Acesso em: 12/30. 2014. 
para o sistema de estudos de arte na sociedade cubana. O projeto ocorreu entre os anos de 2002 e 2009, partindo da ideia de "uma escola de arte concebida como uma obra de arte". Baseado na casa da artista em Havana Vieja, o trabalho era executado com a ajuda de dois funcionários. Dedicado a um processo de formação sobre arte política e contextual para estudantes de arte, o "A Cátedra Arte de Conduta" aceitava somente alunos cubanos $^{86}$. Os participantes do projeto vêm de diferentes campos de atuação: arquitetura, artes visuais, sociologia, música, cinema e mesmo autodidatas. Entre suas iniciativas contou com a criação de um arquivo especializado em arte contemporânea internacional com destaque para o social e a arte performática ${ }^{87}$. Promoveu o intercâmbio entre escolas de vários países e projetos de arte e residências, bem como, agregou a colaboração de profissionais da arte e da crítica de várias gerações de Cuba. Proporcionou a interação com vários sistemas de pensamento para lidar com o fluxo das informações, que permite estender as escolhas dos participantes em sua atuação no contexto social, por meio da arte (Figura 10).
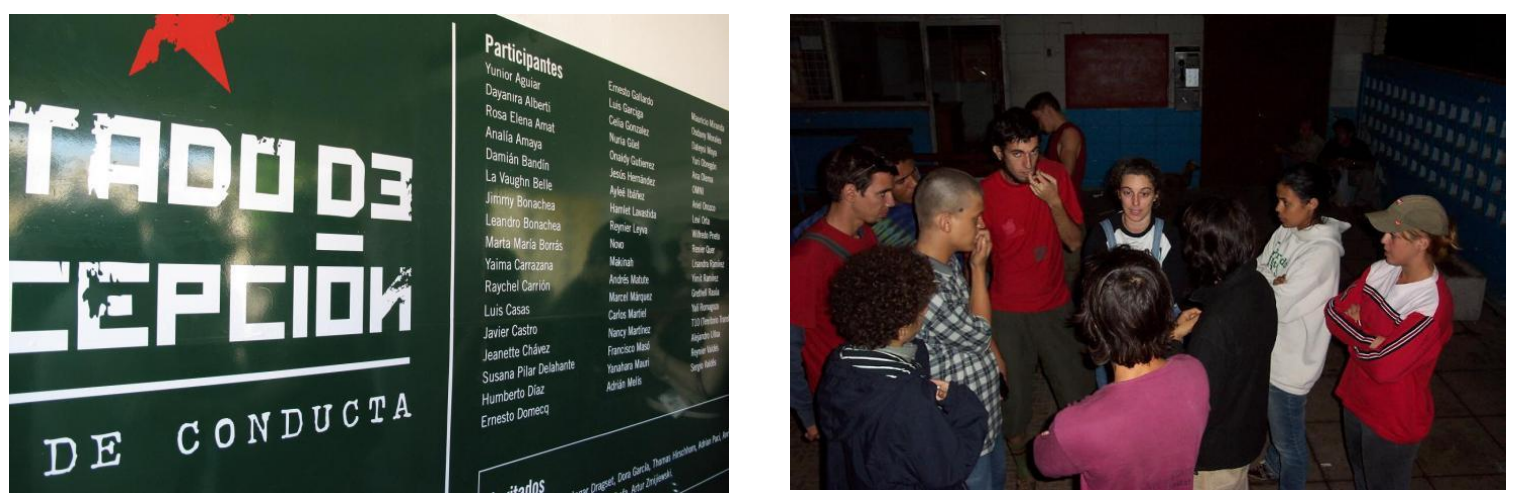

Figuras 10. Cadeira de arte de Conduta. (2002-2009). Fonte: www.taniabruguera.com

Para a artista e educadora, esse era uma forma de responder à queda da qualidade do ensino superior em Cuba que, após a unificação da Alemanha,

\footnotetext{
${ }^{86}$ É importante destacar que o projeto "Cátedra arte e conduta" foi criado no ano de 1998 a partir da "disciplina arte comportamental". Surgiu como uma forma de arte pública com intencionalidades educacionais com o foco de discussão, produção e análise do comportamento sócio -político e de compreensão da arte como instrumentos de transformação da ideologia, de ativação da ação cívica no seu ambiente. Fonte: http://www.taniabruguera.com/cms/492-1Ctedra+Arte+de+Conducta.htm Acessado em 23/05/2015.

87 FINKELPEARL, Tom. "Behavioral Cadeira Art" O que nós fizemos, Capítulo 7: Art Educacional. Ed. Duke University Press Books. 15 de janeiro de 2013. Nova lorque, Estados Unidos (fig.) pp. 179-203.
} 
perdeu financiamentos da Alemanha socialista. Tal episódio teria promovido o aprofundamento da crise cubana e, por conseguinte, colocado obstáculos ao acesso à educação, que passou a ser destinado, principalmente, às pessoas com melhores condições financeiras.

O segundo projeto, por sua vez, consiste em um laboratório de trabalho que tem como proposição testar hipóteses sobre a utilidade da arte. Ele inclui a criação de uma biblioteca com acervo online, publicações e a associação de praticantes da Arte Útil. O "Arte Útil Lab" agrega proposições e busca gerar e mobilizar o pensamento por meio de conversas públicas. Contém outros projetos que serão ativados, bem como material de arquivos elaborados por meio de pesquisas em andamento e de projetos já existentes. Nesse processo, artistas residentes e grupos de trabalho participam de discussões públicas e testam as hipóteses a propósito da utilidade da arte. Isso culminou com a transformação de um dos edifícios, do Van Abbemuseum, na Holanda, no Museu da Arte Útil, no ano de 2103.

A participação da artista na XI Documenta de Kassel, no ano de 2002, foi decisiva para expandir sua atuação no âmbito educacional. O questionamento a propósito da relação efêmera entre o público e as obras, percebido ao longo do evento, instigou Bruguera a desenvolver os referidos projetos, cuja essência está em pensar a educação como um "material que funciona no âmbito do - e como - espaço político" 88 , não como um a priori ou maneira de comunicar conceitos, mas como algo que, por meio das práticas artísticas, gere as reflexões sobre essas relações. Um lugar em que a educação e a arte, pelas suas práticas, operam em contexto, promovem o exercício da alteridade, e a aprendizagem surge como um produto do diálogo. Trata-se, nas ações educativas e na arte, de compreender o termo criatividade como um meio e não como um objetivo encerrado em si mesmo.

Bruguera afirma não querer que sua obra represente algo, mas que as pessoas olhem para o trabalho, que estejam nele, às vezes mesmo sem saber que se trata de $\operatorname{arte}^{89}$. Há nessa perspectiva, a compreensão da e sobre arte,

${ }^{88}$ HELGUERA, P. HOFF. In: Pedagogia no campo expandido/ Organização; Pablo Helguera e Mônica Hoff; Tradução Camila Pasquetti. Porto Alegre: Fundação Bienal de Artes Visuais do Mercosul, 2011. p. 17.

89 GOLDBERG, RoseLee. Ser Cubano (entrevista com Tania Bruguera) Tradução: Caroline Alciones e Luiz Sérgio de Oliveira. In: Poieses/ Revista do Programa de Pós-Graduação em 
não como reprodução das estruturas miméticas de poder que sustentam os processos de aprendizado, mas como a perda de uma condição dupla e simultânea de observador e participante; fazer algo e ao mesmo tempo criticálo.

Não há, nesse sentido, a ideia de arte como educação, mas de educação como arte ${ }^{90}$, um meio para "explorar as maneiras pelas quais as coisas tornamse artísticas"91. Assim, Bruguera estabelece em seu trabalho a relação entre educação, arte e realidade, como um meio de transformar momentos que emergem do mundo da política com base na própria percepção estética.

Essa, talvez seja uma das mais efetivas contribuições da produção contemporânea para o campo educacional, o da investigação de determinado aspecto da realidade que está enquadrado, estereotipado ou formatado pelo senso comum, na tentativa de devolvê-lo à realidade sensível. Uma questão importante para que a arte e seu ensino não sejam compreendidos como uma pedagogia ou explicação do mundo, mas sim, como uma possibilidade para reconfiguração do mesmo, como agenciamentos de relações de regimes heterogêneos do sensível ${ }^{92}$.

Um fenômeno que se traduz no encontro discordante das percepções individuais, na multiplicidade de manifestações e expressões dentro do âmbito formativo, (comunitário, escolar/formal/não formal), que rompe com o universo representativo hierarquizado e reafirma o ensino da arte como um território em que é possível criar, por sua prática, o tecido de novas formas de vida ${ }^{93}$. Assim, afirma-se o estético, ou a estética, não como a teoria da arte em geral ou uma teoria da arte que remeteria a seus efeitos sobre a sensibilidade, mas como um corpo de conhecimento, como uma forma de compreensão das interações entre o campo perceptivo, cognitivo, ético e político, que redimensiona e amplia os

Estudos Contemporâneos das Artes, (p. 123 a 136), 2013. Universidade Federal Fluminense.

${ }^{90}$ Este é um princípio defendido nas obras de Herbert Read, John Dewey e Eliot Einser.

${ }^{91}$ HELGUERA, P. HOFF. Op. Cit. p. 19.

92 Esta orientação está presente nas formulações de Rancière, fundamentalmente, em sua maneira de tratar a relação entre arte e política. Não se trata de compreender a ação política da arte, mas dos agenciamentos no seio de sua própria política. O mesmo pode ser refletido em relação ao ensino da arte. Um regime autônomo, que pode e deve ser atravessado pelas trocas promovidas pelos processos de criação. RANCIĖRE, Jacques. RANCIĖRE, Jacques. A partilha do sensível, estética e política. São Paulo, Ed. 34, 2005. p.10.

${ }^{93}$ Idem, 2012. 
significados do processo formativo, em sua tangência com as demandas que emanam da dinâmica cultural.

Trata-se de, concomitantemente, dividir e compartilhar a experiência sensível comum, que, segundo Rancière, é uma espécie de forma a priori da subjetividade política, uma distribuição inquieta de ocupações e lugares, um modo negociado de visibilidade que " faz ver quem pode tomar parte no comum em função daquilo que faz, do tempo e do espaço em que essa atividade exerce" 94 .

O caminho para pensar a dimensão estética, proposto pelo autor, encontra seu eco no trabalho desenvolvido pela artista e educadora cubana. Uma maneira de operar, de articular e estimular as ações educacionais que intervêm nas relações com as maneiras de ser e as formas de visibilidade, do qual derivam, ao mesmo tempo, um "comum compartilhado e partes exclusivas" ${ }^{\prime 25}$. Um encontro entre as práticas artísticas e as ações educativas como provocadoras de uma relação entre o sujeito e seu lugar, no que é comum, que tenciona e ativa os dissensos e, ao mesmo tempo, contribui para emergência de novas formas de subjetivação e significações coletivas.

Perspectiva que vai em sentido oposto à "estética relacional"96 proposta por Nicolas Bourriaud, cuja proposição aponta como tarefa da arte, uma ideia incorporada ao contexto educacional, o propósito de restaurar as falhas do vínculo social. Tese que se fundamenta em uma ética do encontro, contudo, ignora a lógica hierárquica de um sistema ao qual reproduz. Sendo que, ao cumprir tal missão, "essa arte exaure a invenção política das situações de dissensos que abrem mundos em um mundo que se lhe opõe" $"$.

\footnotetext{
${ }^{94}$ Ranciére, Jacques. Política da arte. Tradução Mônica Costa. Conferência realizada em abril de 2005, no seminário Práticas estéticas, sociais e políticas em debate. São paulo: Sesc Belenzinho. Disponível em ww2.sescsp.org.br/sesc/images/upload/conferencias/2006.rtf. Acessado em: 25/08/2014.

95 Ibidem, 2012, p.15-17.

${ }^{96}$ BOURRIAUD, Nicolas. Estética Relacional. Tradução de Denise Bottmann. São Paulo: Ed. Martins Fontes, 2009.

${ }_{97}$ CÉSAR. Marisa Flórido. Ibidem, p.21.
} 


\subsubsection{A polissemia produtiva das experiências: o corpo social da arte na educação}

As experiências com as imagens propostas por Bruguera por meio das ações no Arte Útil Lab (Figuras 11 e 12), iniciadas em 2003, revelam uma práxis construtiva, a dinâmica permanente de trocas de dentro e fora de um mesmo processo que articula o sentido polissêmico da tangência entre a arte e a educação. Dessa relação emerge uma outra dinâmica, um lugar em que o outro é coautor, material e documento da experiência. Um lugar em que a arte surge como um conceito após a experiência e não como um a priori.

A arte útil, ou ainda, a arte como dispositivo, é uma evidência da transformação mais ampla do que ocorre hoje na arte e na dinâmica social. São iniciativas individuais ou de grupos articulados desenvolvendo novos meios e métodos de organização para tratar de questões que antes eram de domínio do Estado.

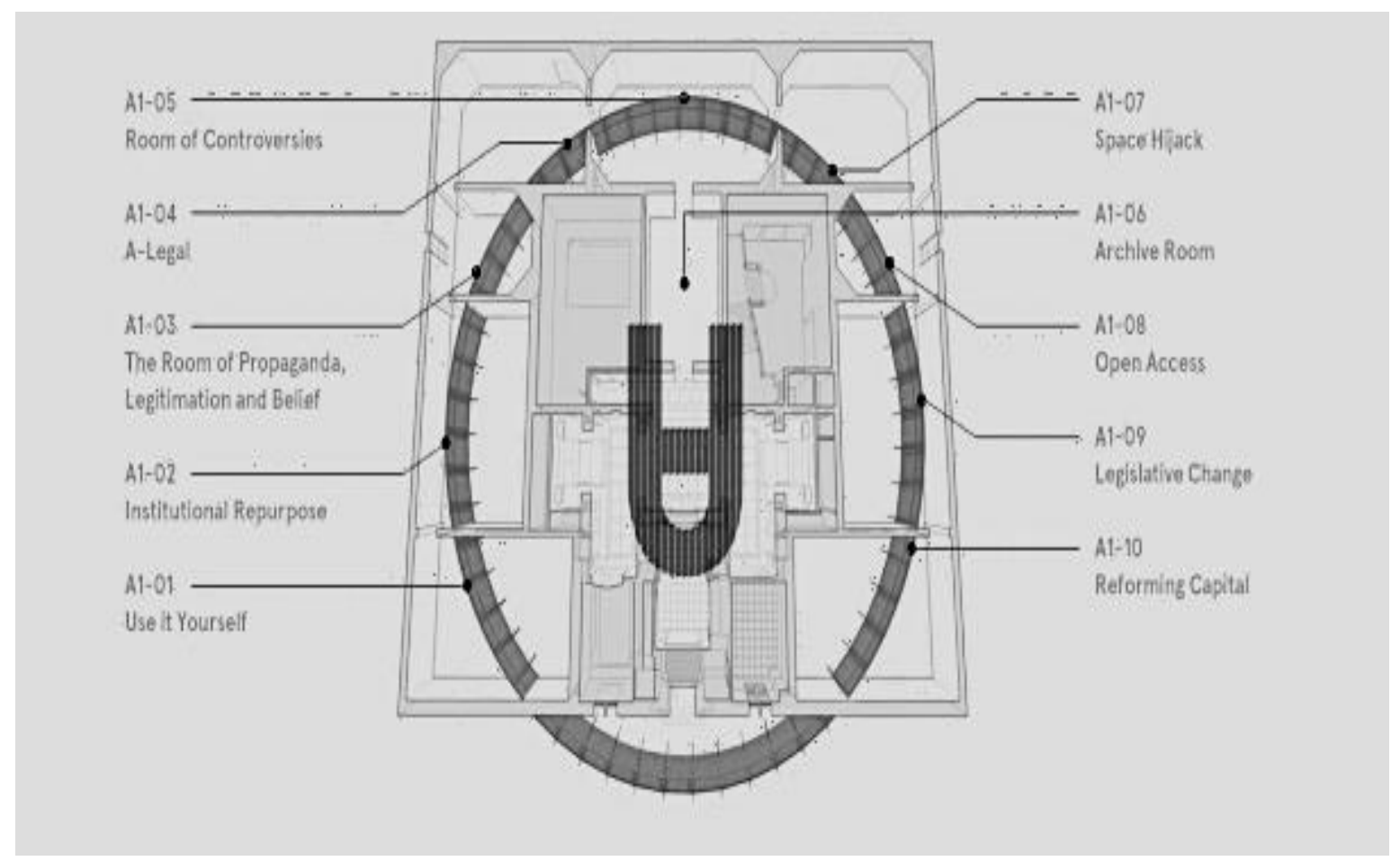

Figura 11. Planta do Museu da arte útil. Fonte: www.museuarteutil.net 

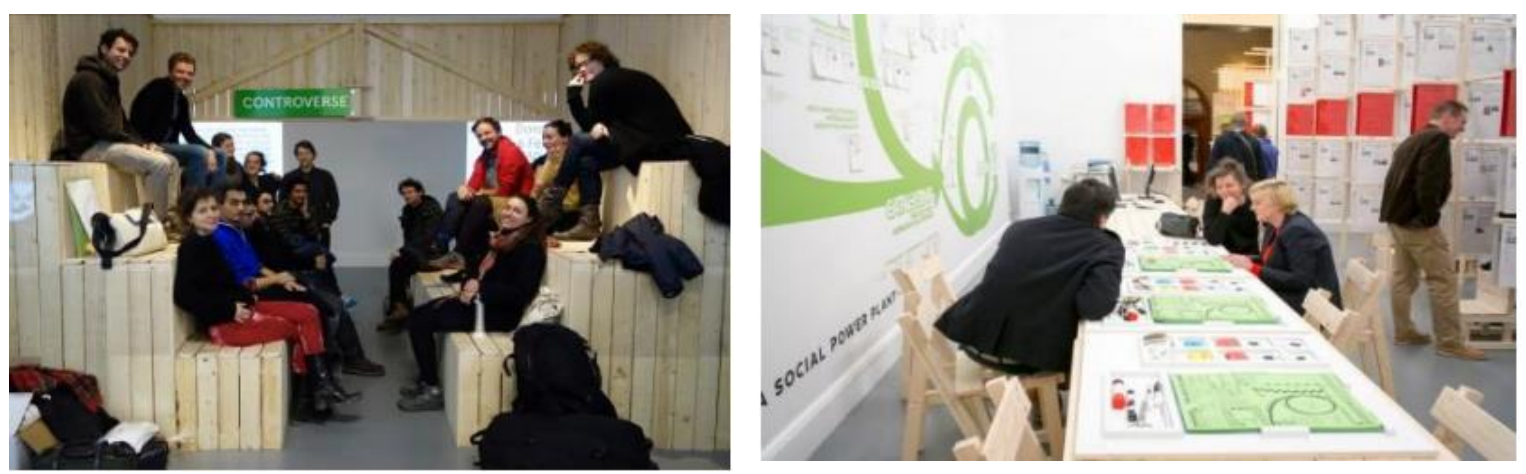

Figuras 12. Museu da arte útil. Projeto de Tania Bruguera no Museu Van Abbemuseum, na Holanda e no Queens Museum of Art, em Nova York. As imagens aqui se referem à sala das controvérsias, um lugar para abordar as questões geradas pelo termo e a prática da arte útil, e a sala central, que abriga as cópias físicas dos estudos de caso, compostos por arquivos sempre abertos e inacabados. Fonte: www.museuarteutil.net

Bruguera pergunta como se pode transformar um museu, uma instituição cultural em uma usina social. As várias experimentações, realizadas em um antigo prédio do Museu Van Abbemuseum e no Queens Museum of Art, em Nova York $^{98}$, não consistem em espaços concebidos apenas para exposições, mas lugares de investigação que se desenvolvem ao longo da execução de projetos, cujo objetivo é explorar as questões que envolvem a utilidade da arte e de suas ferramentas para transformação e interação social. Não é difícil encontrar nas reflexões de Bruguera as influências do educador brasileiro Paulo Freire e do filósofo John Dewey, principalmente, no que tange à função da arte na articulação ética e estética de um outro modo de fazer educação, que vai em sentido contrário a um pensamento linear, único, que não comporta as proposições divergentes, não aceita o contraditório, a natureza transitória de todas as verdades. A educação se apresenta como um lugar para criar coletivamente e desenvolver o potencial social humano.

Na compreensão da artista e educadora cubana, a intenção de um espaço como o Museu da Arte Útil é a de inaugurar, como já afirmado, uma espécie de usina social fundamentada na relação democrática que pode agenciar e atender a diferentes interesses e valores. A forma colaborativa de trabalho, envolvendo usuários, curadores, artistas e funcionários, coloca em pauta um contraponto aos

${ }_{98} \mathrm{O}$ museu da arte útil continua funcionando, também, por meio de uma plataforma online que pode ser acessada no endereço www.arte-util.org. 
interesses privados e enfatiza um uso social (Figuras 13 e 14), gerador de processos de decisão e auto-organização social.

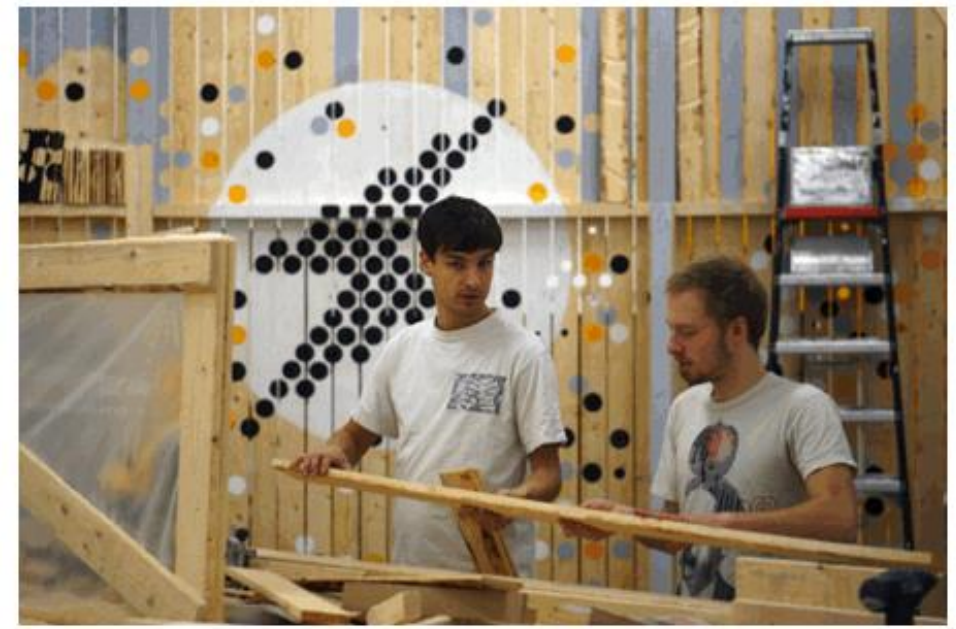

Figura 13. Design como ferramenta - construcLab. Ao contrário do processo arquitetônico convencional, em que um indivíduo projeta e outro constrói, a concepção e construção são unidas. O canteiro de obras é o contexto. Fonte: museumarteutil.net/tools/

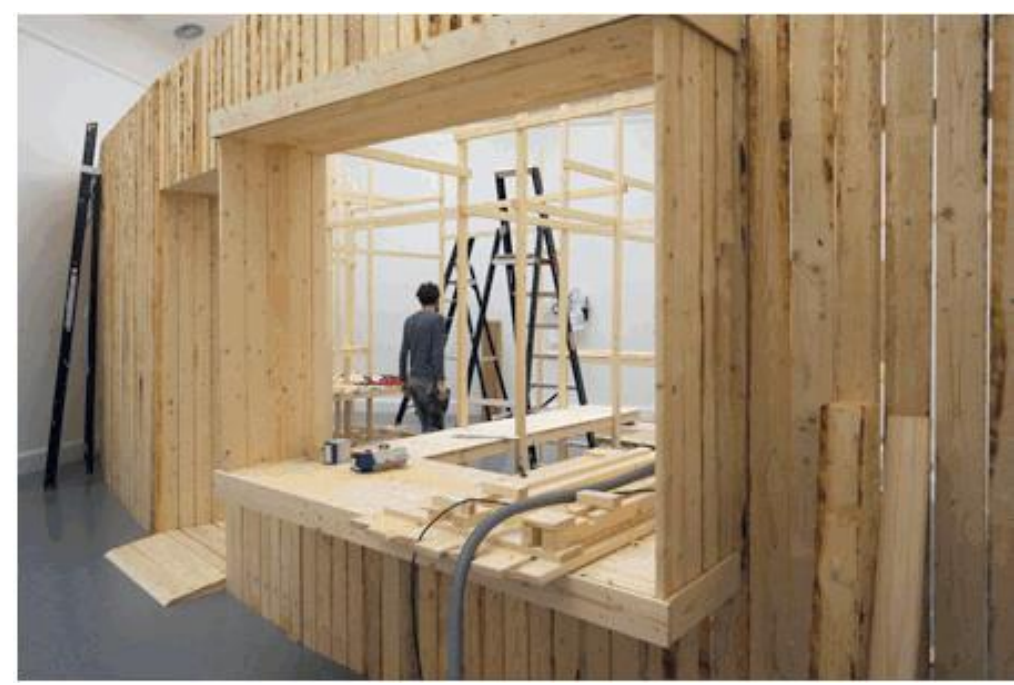

Figura 14. Usina social - ConstructLab. A transformação da sociedade por meio de diferentes modos de operação. Os processos tomam a forma de um jogo que reúne projetos de arte útil como protótipos ou modelos de situações locais. Fonte: museumarteutil.net/tools/

Como se pode observar, a experiência se traduz em espaços de problematização e compartilhamentos, tempos geradores de ações e estudos que, paradoxalmente, consolidam uma espécie de impermanência no processo 
de construção do conhecimento. Uma lógica opositiva aos consensos estabelecidos como verdades gerados por uma educação formalista. Trata-se de pensar na relação entre a arte e a educação como um ato de criar contextos para se experienciar o trabalho, seu conjunto de regras e os compromissos em relação a elas. Mas, sobretudo, pelo processo de criação, da produção estética, promover ações transformadoras que afetam as formas de agir em sociedade. Uma forma de educação estética que tem como eixo um processo de incubação de ideias e ações que produzem as tramas para o feitio de um tecido social auto organizado (Figuras 15 e 16).
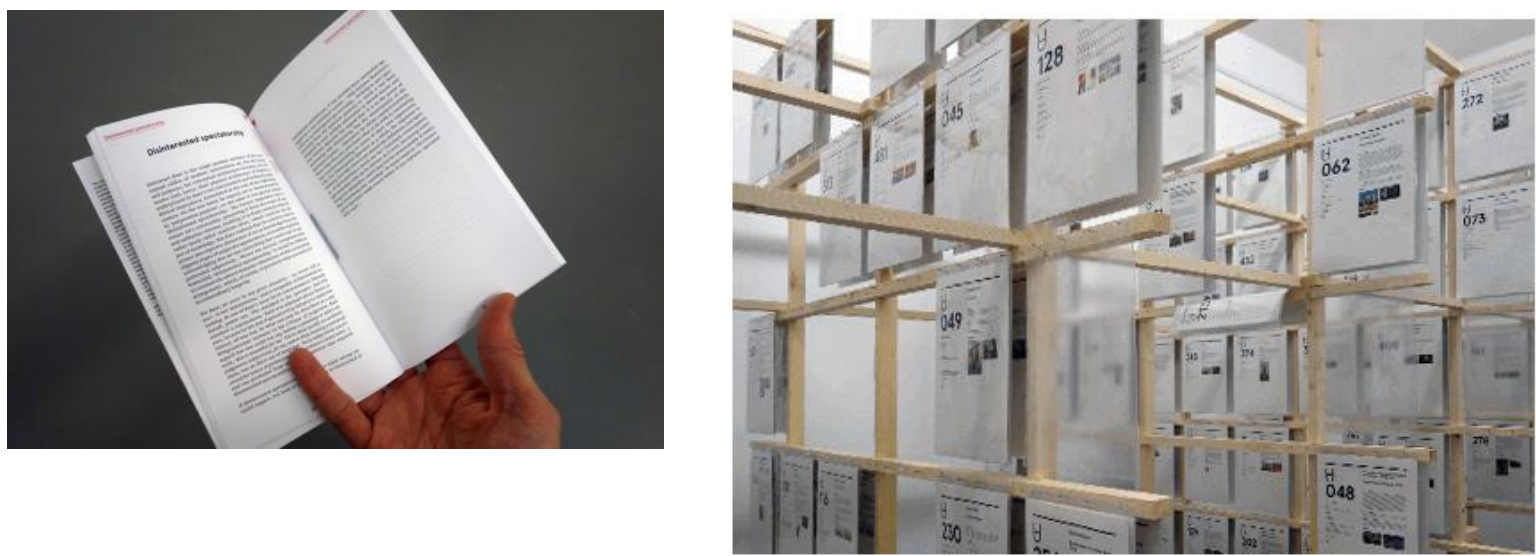

Figura 15. Obras coletivas (Haia/ Mensageiro) - construcLab. O trabalho coletivo se desenvolve entre o local físico e a cidade de Eindhoven, estabelecendo uma ponte produtiva entre as demandas do espaço urbano e o museu. Questões específicas são desenvolvidas com a parceria de usuários locais. Fonte: museumarteutil.net/tools/

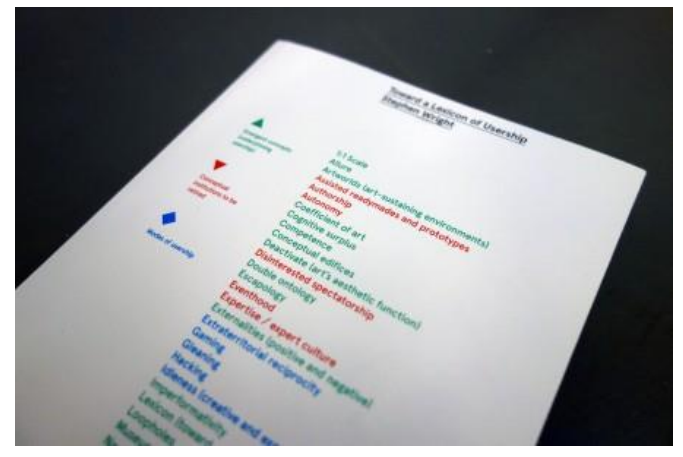

Figura 16. O léxico (dicionário) como ferramenta. Um dicionário de termos foi escrito pelo teórico e professor da Escola Europeia de Artes Visuais, Stephen Wright para o Museu, utilizado como um conjunto de ferramentas textuais para usuários.

Ao abordar questões que desafiam o papel da arte dentro do processo de transformação da vida cotidiana, a perspectiva apontada por Bruguera insere no 
contexto contemporâneo do ensino da arte, o desafio de se pensar sobre as possibilidades de uma real tangência das diferentes expectativas, de que arte e a educação se encontrem em um ponto central, onde o coletivo reconheça a legitimidade dos outros pontos de vista; onde o processo para se criar conhecimento, sua organização e disponibilização, pavimentem os caminhos dos processos de transformação social.

Não se trata de compreender a politicidade da arte como um engajamento estreito, cuja finalidade se encerra em fins sociais específicos e previamente definidos. Mas, sobretudo, de mobilizar, permanentemente, as capacidades de romper com a naturalização das coisas do mundo que estanca os potenciais de experienciar outros modos de fazer e perceber. De exercitar as capacidades de lidar com a forma, experiência e significado, elementos intrínsecos à imaginação artística.

Os fundamentos que estão por trás de projetos como a Arte de Conduta e a Arte Útil evidenciam as tensões que fazem parte do trabalho dessa artista. De um lado, remete às instituições cubanas chamadas "Escola de Conduta" cuja finalidade seria a de reabilitar jovens com problemas de conduta social que não podem obedecer às normas do sistema, onde Bruguera trabalhou como professora de arte, e de outro, reporta à ideia de performance como conduta social, assumindo esse aspecto como material de trabalho para realizar arte pública e social. A Arte de Conduta trabalha entre as interfaces do útil e o ilegal e não se foca sobre os limites da linguagem e do corpo físico mas sobre os limites da linguagem e do corpo social. Assim busca, com a ideia da arte útil, uma outra qualidade do intercâmbio, entre a prática artística e os participantes, para criar condições e possibilidades de romper a fronteira entre o corpo físico e o corpo coletivo. Uma preocupação que afasta, do processo educacional, o culto à forma na arte e a redefine pela amálgama entre o ético e o estético em todo processo.

\subsection{A experiência da imagem}

Há nas práticas artísticas utilizadas como referência, um desenho sócio estético que, de certa forma, não afirma a noção de modernidade estética como 
suficiente para refletir sobre as novas formas de expressão. A relativa eficácia contestatória das vanguardas na arte moderna teve sua força de ruptura contextualizada dentro de um parâmetro histórico que autoriza tais proposições e, ao mesmo tempo, as aparta do mesmo. A própria ideia de modernidade, como afirma Rancière,

[...] é uma noção equivocada que gostaria de produzir um corte na configuração complexa do regime estético das artes, reter as formas de ruptura, os gestos iconoclastas etc., separando-os do contexto que os autoriza: a reprodução generalizada, a interpretação, a história, o museu, o patrimônio99.

Esta concepção traz em si a ideia de um sentido único, que não leva em consideração a co-presença de temporalidades e espacialidades heterogêneas. Premissa essencial para que se possa refletir sobre a contemporaneidade nas artes e em seu ensino. O que justifica a apropriação de meios e modos contidos na tradição, e, no entanto, pressupõe o afastamento do termo estética como uma filosofia ou teoria da arte e de seus efeitos na sensibilidade. Todavia como um "um modo de articulação entre maneiras de fazer, formas de visibilidade dessas maneiras de fazer e modo de pensabilidade de suas relações, implicando uma determinada ideia de efetividade do pensamento" 100 .

Tal abordagem fornece condições de refletir sobre as relações entre as práticas artísticas (modos de operar/fazer) e as práticas estéticas (formas de visibilidade desses modos de operar/fazer) como formas de distribuição do "comum". Entende-se o termo "comum" no ensino da arte, não como um a priori, mas como o "devir" que define o conteúdo do próprio desejo. Tal como agenciamentos entre duas condições de possibilidades desterritorrializantes ${ }^{101}$, "em que não se abandona o que se é para devir outra coisa (imitação, identificação), mas uma outra forma de viver e de sentir102", que define um território onde os sujeitos compõem a subjetividade, constituindo-a sempre socialmente.

${ }^{99}$ RANCIĖRE, Jacques. Estética e política. A partilha do sensível, com entrevista e glossário por G. Rockhill, trad. V. Brito. Porto: Dafne, 2010. p. 08.

100 Idem. Aisthesis. Scènes du régime esthétique de l'art. Paris: Galilée, 2011. p.17

101 O termo desterritorializar é empregado no sentido abordado por Deleuze e Guattari, ao nomearem a subjetividade como um processo de subjetivação-dessubjetivação (DELEUZE, GUATTARRI, 1996).

102 ZOURABICHIVILI., François. O vocabulário de Deleuze. Tradução André Telles. Ed. Sinergia - Relume - Dumará: Rio de Janeiro, 2004. p.24. DELEUZE, 1992, p.08. 
Dessa forma, pode-se abordar a relação entre o artístico e o estético no âmbito da indissociabilidade entre os dois fenômenos e compreendê-los a partir de uma questão essencial para a redefinição da imagem em sua relação com as práticas artísticas no processo educacional. Afasta-se, assim, a possibilidade de pensar em sua constituição como como algo estático, mas como:

\begin{abstract}
[...] uma característica de toda experiência. A arte, em seu sentido específico, retrata de maneira mais deliberada e plena as condições que efetivam essa união. A forma pode então ser definida como a operação de forças que levam à sua realização integral da experiência de um evento, objeto, cena e situação. A ligação entre a forma e a substância, portanto, é intrínseca, não imposta de fora para dentro ${ }^{103}$.
\end{abstract}

A compreensão da natureza da imagem, como destaca Dewey, ao definir a forma, requer o encontro com os meios pelos quais se efetua a condução de uma experiência à sua realização. Não se trata, como pode parecer, de privilegiar a matéria ou forma em sua individualidade, ou mesmo de um domínio dos meios pelos quais se realiza algo, mas da capacidade de articular esses elementos em contexto. De compreendê-los como a parte de um processo maior e complexo que remete à uma lógica biológica.

Embora Dewey não tenha tratado, especificamente, das práticas artísticas contemporâneas, como as que são abordadas aqui, sua obra fornece elementos substantivos para reflexão sobre como o estético em sua forma bruta, contido nos acontecimentos e cenas prendem os sentidos humanos. Essa leitura possibilita a articulação de um conjunto de tensões (materiais e imateriais) que estão veladas pelo cotidiano, nas quais as práticas artísticas atuais buscam o valor estético para suas ações.

Rancière ${ }^{104}$ traz argumentos essenciais para que se possa compreender esta perspectiva teórica e, agrega à orientação deweyniana elementos que apontam a necessidade de revisar os parâmetros da experiência, sobretudo, no ensino da arte:

- Frente ao esgotamento das noções tradicionais relacionadas a experiência estética, a arte passa a ser identificada a partir de um modo de ser sensível que Ihe seria próprio;

103 DEWEY. John. 2010, p. 263-264.

104 RANCIÈRE, Jacques. Idem, 2010. 
- A arte passa a ser definida no singular, livre de qualquer regra, hierarquia, temas ou gêneros. Dessa forma, também se dilui a hierarquia em termos materiais;

- O termo estética não é compreendido como uma filosofia da arte, mas como uma distribuição do sensível, em que são determinados os modos de articulação entre as formas de ação, produção, percepção e pensamento;

- A política da arte é uma atividade que reconfigura os quadros sensíveis no seio do qual se dispõem os objetos comuns, rompendo com a evidência de uma ordem natural que define os modos de fazer, dizer e as formas de visibilidade.

Esse grupo de características dialoga intimamente com a orientação dada por Dewey sobre a experiência como uma atividade que ocorre sempre num espaço relacional, sendo uma forma de compartilhar, uma possibilidade de diálogo. Significa, do ponto de vista formativo, uma troca "ativa e alerta com o mundo; em seu auge, significa uma interpretação completa entre o eu e o mundo dos objetos e acontecimentos"105. Esse é um fenômeno essencialmente comunicacional, em que nem todas as energias são estéticas.

A experiência concreta dos sujeitos é um elemento fundamental para que essas dimensões sejam integradas. Essa interação proporcionada pela arte "é a prova viva e concreta de que o homem é capaz de restabelecer, conscientemente e, portanto, no plano do significado, a união entre sentido, necessidade, impulso e ação" ${ }^{106}$. Uma antítese à dialética de Adorno, segunda a qual haveria uma separação entre as formas puras de arte e as formas da vida cotidiana, com base no argumento,

[...] o homem paga pelo aumento de seu domínio sobre a natureza com a crescente alienação dela. $\mathrm{Na}$ sociedade industrial avançada, o indivíduo se torna supérfluo. O sistema administrativo e a cultura de massas convergem na uniformização da percepção e da linguagem ${ }^{107}$.

A orientação de ordem materialista, neste caso, contraditoriamente parte da formulação kantiana sobre as qualificações do juízo de gosto, de uma finalidade sem fim da arte, e as vincula de maneira transcendente ao seu papel

105 DEWEY, Jonh. Et seq, 2010, p.83.

106 Ibidem, p.93.

${ }^{107}$ ADORNO, Theodor W. Teoria Estética. Lisboa: Edições 70, 1970, p.183; ADORNO, Theodor W. (et al.). Teoria da Cultura de Massa. Introdução, Comentários e Seleção de Luiz Costa Lima. Rio de Janeiro: Paz e Terra, 1986.p. 20; RABAÇA, Silvio Roberto. Variantes Críticas: a Dialética do Esclarecimento e o Legado da Escola de Frankfurt. São Paulo: Annablume, 2004. p. 18. 
social. Ao mesmo tempo que afirma esta finalidade, cobra um valor estético universal e uma postura antagônica e autônoma em relação à sociedade administrada. Adorno afirma que ...

Sendo pura em si mesma, completamente estruturada segundo a sua lei imanente, ela afronta uma sociedade baseada na troca total, onde tudo existe enquanto meio, ser-para-outro; é uma negação determinada de uma sociedade determinada. Desta forma, a arte participa do que lhe é contrário ${ }^{108}$

A pureza, a qual Adorno se refere, está em um suposto refúgio do comportamento mimético da arte, que afasta o pensamento conceitual e faz com que a arte busque a semelhança consigo mesma. Nesse sentido, subordina 0 sujeito à lógica dicotômica que distingue a necessidade da completude do pensamento como algo que também é da ordem do estético, afastando as possibilidades de acesso ao universo da arte como um processo integrado entre as formas de afeto e racionalidade. Além disso, esta abordagem posiciona a arte como uma segunda natureza e afasta do processo estético a concretude das ações humanas, imprescindíveis para compreensão das camadas da realidade no processo formativo.

Nas práticas artísticas abordadas, percebe-se, claramente, que as teses transcendentes, para as quais a tarefa da estética em relação à arte é o de aprender seu conceito de verdade, se desfaz. O que essas práticas revelam é um processo de infiltração simbólica no seio de uma sociedade administrada, que destitui sua pretensão de perpetuar a imagem como um elemento representativo de verdades. Seguindo essa perspectiva, a experiência estética passa a ser compreendida não em termos de transcendência, e sim como "um resultado, o sinal e a recompensa da interação entre organismo e meio que, quando plenamente realizada, é uma transformação da interação em participação e comunicação" 109 .

O que leva a compreender o estético como a qualidade especial que contrasta a imagem formada pela experiência, diferenciando das experiências habituais, mas que, no entanto, somente assume sua completude e unidade na relação entre os sujeitos e o organismo social. Nesse sentido, o estético é uma

108 TROMBETA, Gerson Luís. A Racionalidade Artística como Contraponto À Racionalidade Instrumental. In:Revista Filosofia e Ciências Humanas. Passo Fundo, Ano 11, №. 01, Janeiro/Julho de 1995, p. 77-89

109 Dewey,John. 2010, p.118. 
pré-realidade, um ato, como afirmado anteriormente, de "criar a própria experiência"110, que dinamiza todos os aspectos da vida.

Em que pese o senso comum tratar a produção contemporânea nas artes visuais como algo de difícil acesso, ela se integra, pela sua apropriação dos elementos extra estéticos, ao comum da vida. Nesse sentido, processos de criação e compartilhamento, como os de Martin Sastre, Marcela Tiboni e Tania Bruguera, informam sobre as transformações que carecem de ser apropriadas no campo educacional. Principalmente, porque as experiências que surgem da relação com esses trabalhos rompem com a tradicional relação sujeito/objeto, promovendo a auto expressão como algo que contribui para que os sujeitos agreguem novos significados à sua condição cultural. São poéticas cujas características impõem uma nova percepção da imagem:

- Na diferenciação projetual;

- na efemeridade (em que ficam apenas os registros);

- no trabalho em rede e de autoria não exclusiva (o artista perde o controle total de sua produção);

- nas práticas baseadas em contextos e em eventos;

- no diálogo atemporal com a arte

Características tais que podem trazer para o ensino da arte a necessidade de um trabalho voltado para o coletivo, o solidário, o dionisíaco (como acompanhamento dos processos através da experiência como aventura), elementos que comungam com a ideia de formação como criatividade.

No entanto, as experiências que vêm sendo proposta por meio dessas práticas artísticas, que dotam os problemas da vida ordinária de qualidade, e intimam os sujeitos para uma evidente interação com o ambiente, ainda desencadeiam conflitos nos processos de abordagem pedagógica. Isso porque, hegemonicamente, o ensino da arte, em todos os seus níveis, dentro e fora do ambiente escolar, ainda comporta um conceito de imagem/forma que não encontra correspondência nas referidas práticas. Dessa forma, torna-se necessário rever o conceito de imagem/ forma para alimentar as reflexões ligadas a um conhecimento transdisciplinar que envolve a arte e seu ensino.

110 Idem, p.137. 
A imagem nunca é uma realidade simples. Antes de tudo são modos de operar, um jogo que envolve o pretérito e o depois, causas e efeitos, mas, sobretudo a alteridade, ou seja, o outro como condição necessária para sua existência. O método aristotélico por abstração coloca o problema central sobre o conceito de imagem/forma, o princípio da não contradição. $O$ ente não pode ser e não ser ao mesmo tempo, sob as mesmas circunstâncias. Tem-se, designado, no ensino da arte, o termo imagem a toda sorte de figuras. No entanto, se vivemos num mundo de imagens, o que diferencia o trabalho da arte de outros?

Ao considerar a forma/imagem como um elemento de compreensão da natureza intrínseca da experiência artística, Dewey desfaz essa contradição. Destaca o aspecto cumulativo das práticas que dão sentido à essas imagens/formas (ideia, projeto, organização dos meios e modos, manipulação da matéria ou da imaterialidade por meio da expressão e, a maneira de apresentar/relacionar isso ao/com público/outro) como constituintes de um todo cujas partes têm valores específicos. Mas que, ao estabelecerem relações de continuidade com os processos normais de viver, ativam outros valores, tensões e resistências de ordem intelectual e sensível, que serão resignificados, constituindo um novo padrão.

Esta definição não pode ser aplicada a qualquer figura, ou imageria. Mesmo que a produção contemporânea tenha um dos seus focos na ressignificação das coisas ordinárias, o endereçamento continua sendo estético. As imagens da arte não remetem a nada além delas mesmas, no entanto, isso não quer dizer, como afirma Rancière, que são intransitivas. Elas são operações: "relações entre as partes, entre uma visibilidade e uma potência de significação e de afeto que the é associada, entre as expectativas e aquilo que vem a preenchê-las"111.

Dessa definição, que também pode ser identificada na obra de Dewey, nasce um conceito de imagem que se apresenta como transversal para o ensino da arte. A imagem/forma como um análogo da própria prática artística, como um fenômeno que envolve todo a ação que visa consolidar a experiência estética em um processo formativo. Refere-se a um ato de "criar a própria experiência"112,

111 RANCIÈRE. Jacques. O destino das imagens. 2012, pp. 08-12.

112 DEWEY, Jonh. Et seq. 137 
de ativar os processos que levam à sua consumação, não pela utilização dos meios por eles mesmos, ou pela apreciação de objetos, mas pelo encontro comunicacional entre as práticas artísticas e as interações que resultam na estranheza das proporções que integram uma dinâmica desigual e combinada, que se efetiva em algo novo. Um processo em que "as ações e suas consequências devem estar unidas pela percepção" ${ }^{113}$, construindo a abertura, para que no processo educacional seja possível ...

[...] lidar com o irrepresentável que desconcerta todo pensamento...comunidades, espaços e lugares nos quais se dão as trocas, as acolhidas, as escutas, as criações das pessoas com seus saberes locais atravessadas por não-sabidos, transformando-os em processos de criação ${ }^{114}$.

Superar a conviç̧ão de que o ato estético deve ser vivido e não criado, entender que $\mathrm{o}$ ato de criação é uma negociação consciente entre o eu e 0 mundo, entre o ficcional e a realidade, um elemento medial dos processos artísticos, é uma condição necessária que possibilita a experiência e fundamenta a natureza epistemológica da arte. Se Dewey aponta que o artístico se refere ao ato de produção, e o estético, de percepção, "a inexistência de um termo que designe o conjunto dos dois processos é lamentável”"115. Talvez essa designação possa nascer do próprio ensino da arte, como um sinônimo de compartilhamento da união desses saberes.

113 Ibidem, p. 122.

114 FRANGE, Lucimar Bello. A Experiência estética em ações colaborativas, inquietantes.

Poéticas em práticas pedagógicas. In: XXIII CONFAEB: Porto de Galinhas/PE - Anais, 2013. p. 3414.

115 DEWEY, Jonh.2010, p.126. 


\section{Capítulo 2 - Meridianos: da sinergia ao diagnóstico}

Os acontecimentos, os processos, as pessoas e os grupos sociais, a observância de um fenômeno contemporâneo inserido em seu contexto real de vida definiram o estudo de caso como alternativa metodológica. Pautado nessa orientação, posto que as principais indagações feitas ao objeto envolvem "como" e "por que", a tese apresenta um delineamento de estudo de caso, referenciada, principalmente, no trabalho desenvolvido por Yin ${ }^{116}$, que busca apreender a totalidade de um fenômeno por meio da complexidade social nas qual ele se manifesta.

$\mathrm{Na}$ abordagem investigativa os estudos de caso são adequados em três contextos. Situações de pouco e nenhum controle sobre os eventos examinados, como indicado anteriormente; quando o enfoque se fixa em fenômeno contemporâneo no contexto da vida real, e, por fim, quando a pretensão é a descoberta, com amplitude e profundidade de algum fenômeno.

Os questionamentos de ordem teórica apontados anteriormente, cuja essência se fixa na alteridade da imagem e da experiência, promovem o agenciamento do que é perquirido no campo empírico e, por sua vez, deve estar alinhado aos objetivos da investigação. De acordo com o exposto na Figura 17, a problematização, a hipótese e objetivo geral da pesquisa se refletem no estudo de caso.

116 YIN, Robert K. Estudo de caso. Planejamento e métodos. Tradução: Ana Thorell; 4 ed.Porto Alegre: Bookman, 2010, p.07 -22. 


\section{PROBLEMAS}

- Como as práticas artísticas contemporâneas podem contribuir para o ensino e aprendizagem nas artes visuais?

- Como os artistas educadores desenham estratégias para lidar com o processo de ensino da arte?

\section{PROBLEMA ADAPTADO AO ESTUDO} DE CASO

- Como as práticas artísticas do ator chave se apresentam ao longo do período analisado?

- Como a experiência da e com a imagem se realiza no trabalho da artista?

- Como são ativadas as políticas cognitivas por meio da experiência com e da imagem?

Figura 17: Espelhamento entre objetivo - hipótese e problemas entre os campos teórico e do estudo de caso no âmbito da pesquisa

\section{OBJETIVO DE PESQUISA}

- No processo educativo, as transformações nas práticas artísticas contemporâneas não foram assimiladas como problematizações que ampliam as possibilidades do campo educacional, bem como contribuem para construção social do sujeito e dos modos de existência, como um território de autoria.

\section{HIPÓTESE ADAPTADA AO ESTUDO} DE CASO

\section{-A prática dos artistas educadores} contemporâneos articula experiência com a imagem e processo pedagógico, trazendo contribuições para o ensino e aprendizagem da arte.

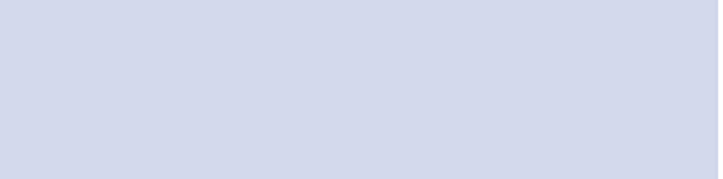

Compreender qual é o papel/funcão do ensino da arte, da experiência com e da imagem, em um universo complexo de narrativas que não mais se fixam à ideia de universalidade.

\section{OBJETIVO DO ESTUDO DE CASO}

- Analisar a trajetória da artista educadora e pesquisadora contemporânea Lucimar Bello Frange para compreender como são desenhadas as estratégias no processo formativo.

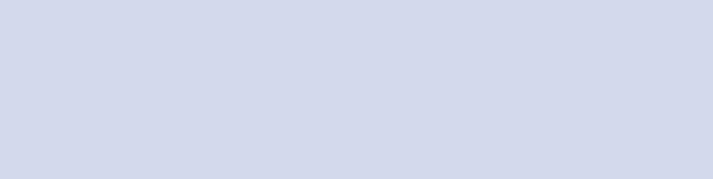


A problematização feita na análise do fenômeno mais amplo pode ser reproduzida e adaptada ao caso, que implica em indagar acerca dos processos e das estratégias em seus desdobramentos, em termos de práticas didático pedagógicas. O mesmo se dá com a hipótese e com o objetivo geral, considerando que há o entendimento, exposto à análise e interpretação dos dados empíricos, que as práticas artísticas e educativas, tal como aquelas que podem ser apreendidas pela trajetória da artista educadora contemporânea pesquisada, podem contribuir para as reflexões na educação em arte. Nesse sentido, o estudo de caso configura uma estratégia de pesquisa para abordar o complexo fenômeno definido como objeto de pesquisa.

Apesar de ser um método aplicado historicamente em pesquisas nas ciências sociais e nas áreas de saúde, ele tem sido utilizado e considerado válido para o campo educacional. Apenas em 1994 teve seu primeiro esforço de estabelecimento de protocolos realizados e tornados públicos por meio das obras de Robert Yin. A partir dessa década, o autor tornou-se referência nas investigações sob esse método. Não se trata apenas do ineditismo, mas, sobretudo, da consistência normativa dos mecanismos propostos.

No entanto, cabe ressaltar que a experiência de Robert Yin privilegia a abordagem metodológica por meio de equipes de pesquisadores, deixando a inquirição em um nível individual relegada a um segundo plano. Destarte, cabe uma breve alusão, ou advertência no que se refere ao contexto da pesquisa no Brasil. A tradição da investigação acadêmica, tanto em mestrados, quanto em doutorados, ainda se define pelo perfil solitário. Além disso, é bastante comum que nas investigações coletivas, situação em que os vícios positivistas se manifestam a rigor, a divisão do trabalho não se defina pelo intercâmbio reflexivo, mas por tendências individualistas e protecionistas.

Seguir rigorosamente as recomendações acerca das teorias do estudo de caso, elaboração de protocolo, entrevistas, observações diretas e participantes e outras formas de coleta de dados, triangulação de fontes, demanda muito tempo e recursos. O que, por sua vez, promoveu a necessidade de uma adequação metodológica e da adesão ao modelo de caso único com enfoque 
holístico ${ }^{117}$. Em que pese a discussão teórica ter sido elaborada com análise de fonte documental relacionada a trabalhos de outros artistas contemporâneos.

A crítica ao modelo de caso único está fundamentada no argumento de que um dos maiores riscos de um estudo de caso com essas características é a possibilidade do investigador ignorar pontos importantes do processo, exatamente, por não isolar as fontes em unidades lógicas. Em função disso considerou-se o desenho da pesquisa fundamentado em um seu caráter instrumental, com o foco nos modos de operar de um ator chave como unidade de análise e veículo para compreender o fenômeno investigado.

Por meio dos estudos da tríade: práticas artísticas, experiência da e com a imagem, e, políticas cognitivas; considerou-se que a técnica de triangulação ${ }^{118}$ de métodos reduziria o risco de conclusões reducionistas próprias da utilização de um caso único. Essa técnica consiste no fato do pesquisador, além de posicionado em um ângulo do problema, se colocar, no mínimo, em outros dois pontos de vista. Recurso que almeja ajustar a adequada distância para a análise e interpretação do fenômeno em pauta. Essa combinação de métodos busca na inferência das convergências um caminho epistemológico fundamentado no cruzamento das fontes de dados distintas, das impressões do investigador em contextos diferentes, do confronto das teorias e/ou hipóteses

A arte, tanto em seus modos de operar, quanto na recepção que instiga, é um processo complexo e contínuo de interação material e simbólica com a realidade. Não seria pertinente pensar em uma abordagem metodológica que tratasse do propósito de compreender a produção da imagem e sua relação com a experiência no ensino e aprendizagem contemporâneo da arte, a não ser pelo caminho de complexidade. Por meio da compreensão das linhas de ...

[...] um tecido (complexus: que está tecido junto) de construções heterogêneas inseparavelmente associadas: apresenta o paradoxo do uno e do múltiplo. Ao olhar com mais atenção, a complexidade, efetivamente, é um tecido de eventos, ações, interações, retroações, determinações, azares que constituem nosso mundo fenomênico ${ }^{119}$.

Dessa forma, é possível julgar a experiência da imagem como uma realidade que comporta uma dupla perspectiva. Por um lado, há uma

\footnotetext{
117 Ibidem. p.82.

118 Ibidem, p.33.

119 MORIN, Edgar. Introducción al pensamiento complejo. Barcelona: Gedisa, 1996.
} 
complexidade sistêmica _ a diversidade de agentes. Cada qual com uma participação diferenciada, tanto no campo educacional, como/e no contato com a arte. Isso em função de seus recursos culturais, materiais e das posições sociais que ocupam. De outro lado, existe a complexidade fenomênica _ a diversidade de interpretações que essas condições assumem em cada contexto da experiência. Visto que, os distintos agentes se relacionam com o fenômeno de maneira diferente e constroem interpretações distintas, a compreensão das interpretações de cada um deles é relevante para análise do fenômeno e exige uma abordagem específica.

Em termos de tipologia, a orientação se define pelo estudo de caso exploratório, analítico, instrumental e holístico. Exploratório em função de agregar informações a propósito do objeto sobre o qual se debruça, a fim de orientar a formulação de hipóteses. Analítico porque problematiza o objeto com a intencionalidade de dinamizar o exercício das práticas reflexivas que visam trazer novas questões ao campo teórico. Embora o analítico vise a construção de teorias, não houve tal presunção. Mesmo porque, em um estudo de caso único, não se sustenta tal pretensão. Mas é importante enfatizar que em uma situação de pesquisa coletiva, com os aportes e recursos necessários, isso seria possível. Prosseguindo, a investigação instrumental ou crítica, se coloca no diálogo com as preocupações de teóricos que já desenvolveram instrumentos de decodificação ${ }^{120}$.

Em qualquer dessas situações, deve-se ter a compreensão de que o que é observado in loco como um fenômeno social complexo, deve ser explorado a partir de suas características holísticas, como eventos que expressam a vida. Dessa forma, o que é investigado passa a ser percebido como um sistema cujas partes são integradas e interdependentes ${ }^{121}$.

Concerne aclarar que por metodologia considera-se "o caminho do pensamento e a prática exercida na abordagem da realidade" 122 . A finalidade do método é refletir em uma perspectiva construtiva, que integre a dimensão

120 STAKE, Robert. E. Pesquisa qualitativa: Estudando como as coisas funcionam. Penso Editora. Porto Alegre, 2011.

121 STAKE, Robert. E. Pesquisa qualitativa/naturalista: Problemas epistemológicos. In: educação e seleção n.7, 2013, p.19-27.

${ }_{122}$ MINAYO,Cecília de Souza (org); GOMES. Suely Ferreira Deslandes Romeu. Pesquisa social. Teoria, método e criatividade, 34 ed. Editora Vozes, 2015, p. 14. 
material e a dimensão simbólica da realidade, na qual os agentes vivenciam o fenômeno. Daí a importância de estabelecermos um ciclo de pesquisa, um processo de trabalho em espiral que se inicia com os questionamentos e finaliza com respostas que dão origem às novas perguntas.

Explorar hipóteses ou pressupostos e escolher instrumentos para a operacionalização do trabalho, configurou-se como uma fase de exploração. $O$ trabalho de campo articulado ao manancial teórico, derivado dessa fase exploratória, concederam sentido relacional e prático de fundamental importância para a compreensão dos aspectos da realidade no qual o fenômeno está inserido. Sem o rigor dessas etapas não seria possível trabalhar as análises ou formulações que pudessem propiciar a construção de descobertas.

$\mathrm{O}$ ciclo de pesquisa não se fecha. Tanto mais, quando as fontes carecem de abordagens distintas, que por suas peculiaridades provocam a formulação de novos pressupostos. No entanto, nesse processo, é possível entender que a provisoriedade é inerente à dinâmica da vida e dos processos sociais que têm 0 seu espelhamento nas construções teóricas. São descobertas que precisam conviver entre a ordem e a desordem das subjetividades e objetividades por meio de ordenação de dados, da sua classificação e análise. Um exercício artesanal e intelectual que se

[...] contrapõe e se completa, percorrendo da abstração teóricoconceitual e de conexão com a realidade empírica, de exaustividade e síntese, de inclusões e recortes, e, sobretudo, de rigor e criatividade ${ }^{123}$.

A viabilização dessa escolha se sustenta na abordagem baseada no multimétodo, que se distingue pela análise diferenciada de cada fonte e busca no cruzamento das evidências a introspecção sobre uma temática, que proporciona conhecimento sobre algo que não é o caso em si, mas a facilitação e compreensão de algo mais amplo.

123 Ibidem, p. 31. 


\subsection{0 nascimento da ordem}

O subtítulo que dá sequência à reflexão sobre o multimétodo, nasce da pergunta de Morin ${ }^{124}$, _ de onde nasce a ordem? Na simultaneidade entre caos e ordem, as imposições das forças contrárias dão início a um processo construtivo. Ao mesmo tempo orientam e limitam as verossimilhanças na dinâmica de um jogo que constituem a primeira ordem. Trata-se de pensar das partes ao todo e do todo à recusa consciente da simplificação, da redução positivista que persegue a disjunção, conferindo à investigação uma abordagem linear. A afirmativa de Morin que "aceitar caminhar sem caminho, fazer o caminho no caminhar"125, significa não encerrar a realidade na ordem de um sistema e deixa-la contaminar-se pelo que é estranho à uma racionalidade normativa.

No estudo de caso fundamentado no multimétodo, a abordagem de cada fonte, por meio de suas singularidades e inter-relações, conduz à dinâmica que busca, ao mesmo tempo, o que é comum e o que é particular em cada caso. No entanto, o corolário desse processo expõe algo, que, segundo Stake ${ }^{126}$, decorre de um ou mais dos seguintes aspectos: a natureza do caso; o histórico do caso; o contexto, que nessa investigação envolve aspectos artísticos, estéticos e educacionais; os informantes pelos quais pode ser conhecido. Isso posto, a pesquisa qualitativa, fundamentada neste estudo de caso segue a ordem epistemológica sistematizada na Figura 18.

124 Morin, Edgar. 0 método, 1. A natureza da natureza. 2 ed. Tradução Maria Gabriela de Bragança. Publicações Europa-América. 1977, p.52.

${ }^{125}$ MORIN, Edgar. op cit, p.25 et seq.

126 STAKE, Robert. Op. cit. p.19-27. et seq. 
Percepçẫo do fenômeno.

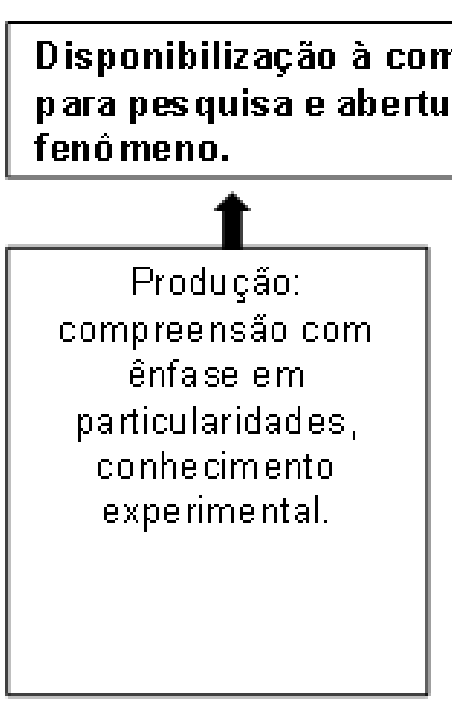

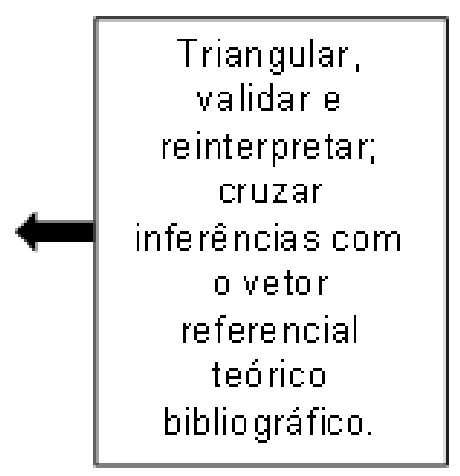

Selecionar situaçỗes relevantes; entrevistar e registrar; identificar casos especiais.

Figura 18. Ordem epistemológica da percepção ao conhecimento.

A investigação de caráter transdisciplinar foi realizada por meio de três vetores de abordagem do objeto, cada um deles sustentado por um método, conformando a referida abordagem multimétodo. $\mathrm{A}$ análise e interpretação, por sua vez, foram viabilizadas em sua articulação ao referencial bibliográfico, com base na triangulação dos resultados obtidos na coleta e na convergência de evidências como expresso na Figura 19. 


\section{Áreas de convergências e produção de evidências.}

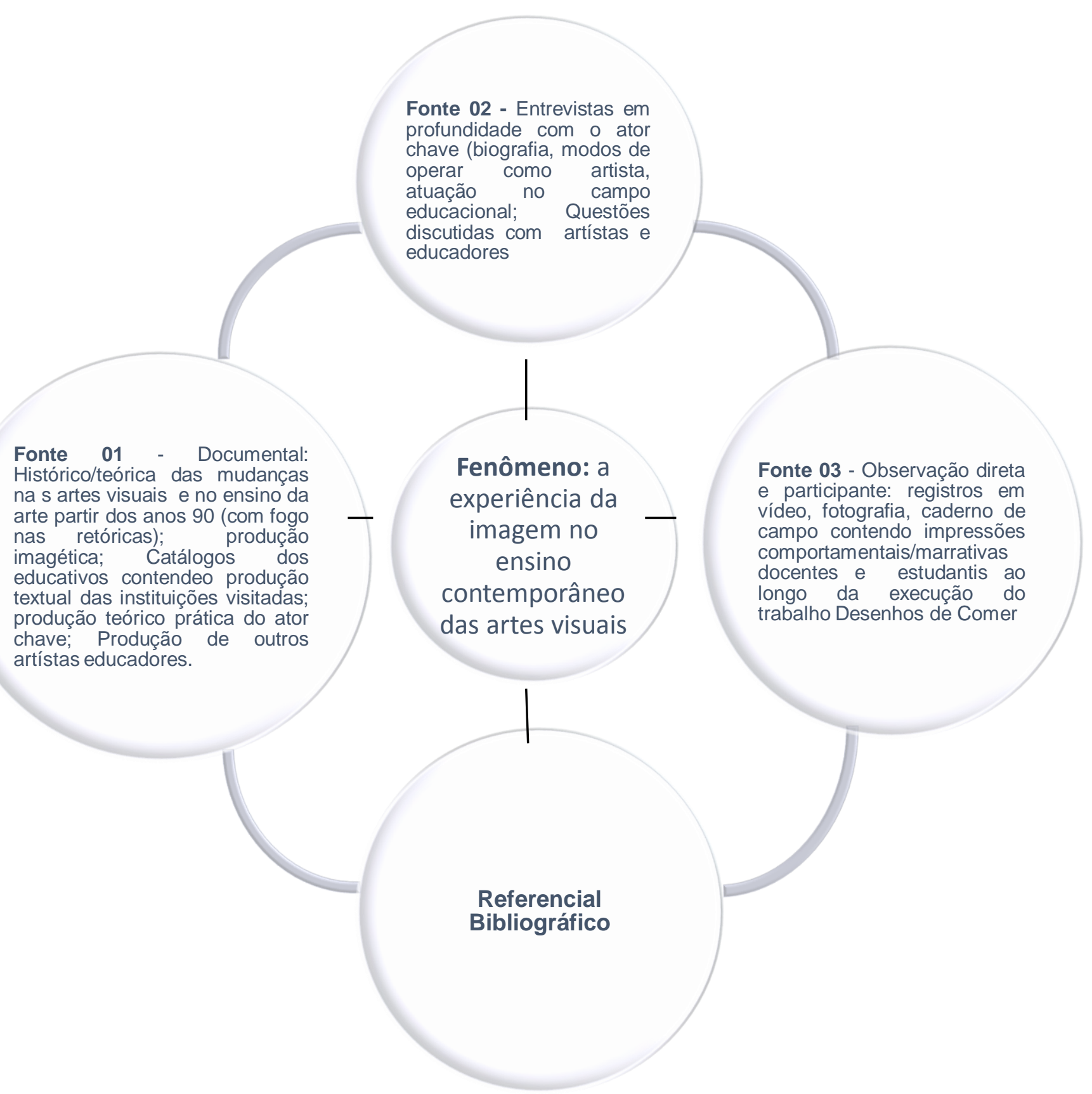

Figura 19. Esquema metodológico. 


\subsection{O primeiro meridiano: documentos escritos e iconográficos}

A primeira etapa desse processo consistiu em coligir informações brutas. Depois da coleta, procedeu-se à seleção do material relevante com base no problema de pesquisa. A pesquisa documental deve ser um trabalho de precisão, anotação minuciosa. Os fichamentos e resenhas do referencial teórico escolhido devem estar à disposição para que os dados documentais recolhidos em campo sejam selecionados, organizados e depurados com o foco no problema de pesquisa.

Nesse sentido, o foco se deu no trabalho do ator chave, sobre o qual foram reunidas diversas fontes (textos/imagens), caracterizadas como fontes documentais.

No que se refere aos documentos escritos optou-se pela adoção das recomendações de Létourneau ${ }^{127}$, que envolveram os seguintes procedimentos:

- Leitura atenta dos documentos: esse processo consistiu em registrar todas as particularidades dos documentos que despertavam relações com o problema de pesquisa. Expressões, noções e palavras consideradas de importância significativa foram destacadas e articuladas ao referencial teórico, como também às anotações de campo em forma de síntese para que pudessem ser consultados com facilidade.

- Comentários: consistiu na formulação, em termos de notas, como processo de interpretação. Trata-se de um exercício intelectual que garante ao pesquisador uma atenção específica aos como e por quês das publicações. Esse processo foi imprescindível para o aprofundamento e para estabelecer as relações conceituais entre a bibliografia em termos gerais e os documentos extraídos de situações específicas, com propósitos direcionados ao campo educacional.

- Reconstituição do esquema analítico dos documentos: essa etapa dá seguimento à análise das informações e particularidades

127 LÉTOURNEAU. Jocelyn. Ferramentas para o pesquisador iniciante. Trad. Ivone C. Benedetti. Editora Martins Fontes. São Paulo, 2011. p.100,101. 
contidas nos documentos. Aqui foi estabelecida uma articulação entre a estruturação lógica dos textos, a maneira como eles foram apresentados, inclusive, em termos de suas imagens/ou ausência delas.

- Avaliação final: esta última etapa tirou proveito das operações que a antecederam. Seu propósito foi chegar, como afirma Létourneau ${ }^{128}$, a uma ideia de conjunto sobre as qualidades intrínsecas dos documentos.

Os procedimentos acima citados podem ser sintetizados da seguinte maneira (Figura 20):

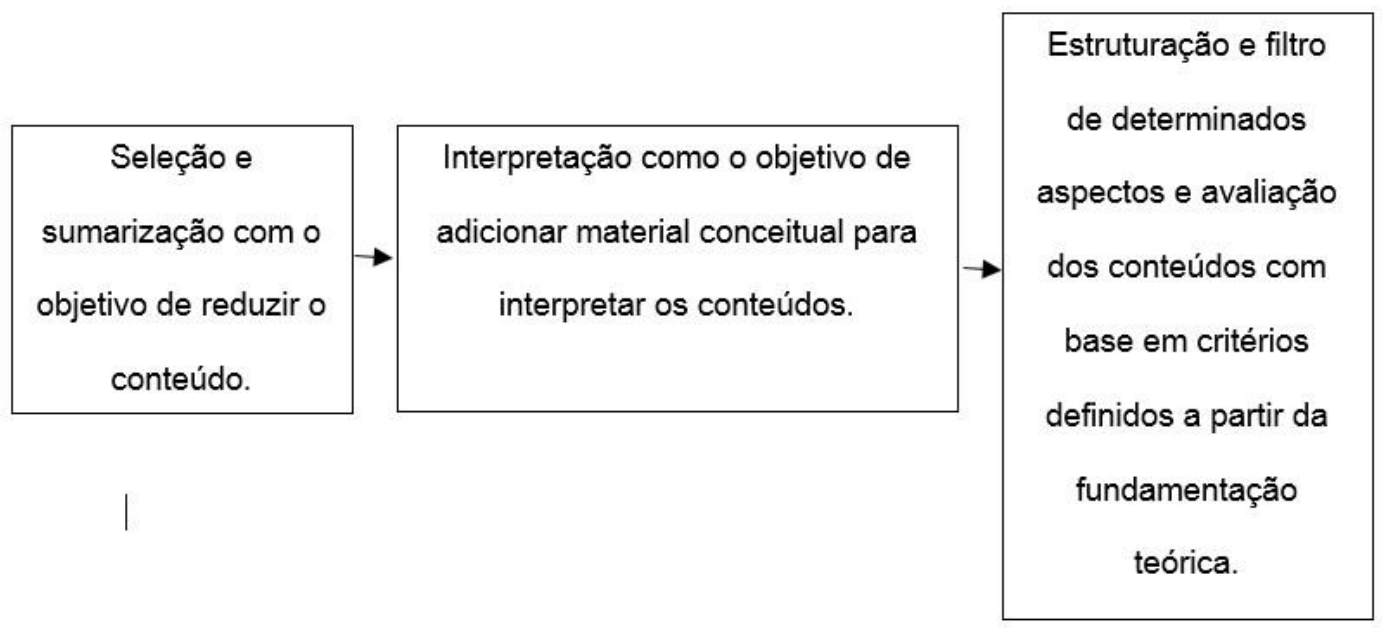

Figura 20: Síntese da sequência procedimental na seleção e análise documental.

\section{Documentos iconográficos}

A análise das imagens, ou como é definido no campo artístico, o estudo das representações referentes a determinado motivo, foi realizada com base nas intencionalidades educativas. Não se trata de refletir sobre o conteúdo iconográfico por ele mesmo, mas de pensá-lo em sua dimensão de 
compartilhamento. Evidentemente, algumas etapas foram seguidas para viabilizar a reflexão sobre o conjunto de imagens que compõe este trabalho. No entanto, como elas têm fontes diferentes, também necessitaram de métodos diferentes de análise.

A observação atenta, a detecção de componentes e significados desses documentos foram divididos em três grupos. O primeiro diz respeito às incursões em campo. As imagens coletadas durante as visitações, cujo propósito era compreender as ações e orientações de professores e estudantes em espaços expositivos, bem como o material iconográfico de referência do autor da pesquisa, contribuíram para definir a problemática de pesquisa, nortear 0 desenho dos objetivos, além de permitir o diálogo com o corpo teórico da pesquisa. $O$ segundo se refere às próprias imagens autorais do ator chave $\mathrm{e}$ aquelas que documentam seu trabalho, estas sim, foram analisadas de forma articulada aos documentos, contribuindo para a compreensão de sua trajetória.

\subsection{0 segundo meridiano: das entrevistas}

O estudo dos modos de operar da artista, educadora e pesquisadora Lucimar Bello Frange, como unidade particular e central da investigação, somada à base de coleta empírica e teórica, designa o vínculo para compreender e descortinar o problema de pesquisa.

Nesse vetor foram realizadas entrevistas em profundidade ${ }^{129} \mathrm{com} o$ ator chave da pesquisa, a artista, educadora e pesquisadora Lucimar Belo Frange. As entrevistas foram balizadas por temas norteadores do diálogo pesquisadorentrevistado e envolveram aspectos tais como: as problemáticas relativas à produção contemporânea em artes visuais, em termos de sua materialidade e territórios; o ensino e aprendizagem da arte na contemporaneidade; referências imagéticas da artista; modos de produção e processos de atuação no campo

\footnotetext{
129 Idem. p. 64. As entrevistas em profundidade ou abertas, em que o ator chave é convidado a discorrer livremente sobre um tema ou questões do investigador, buscam dar mais densidade às reflexões. Destaca-se que, no caso dos outros arte-educadores abordados, a técnica utilizada foi a sondagem de opinião, que está condicionada às perguntas formuladas pelo investigador. (p. 64).
} 
educacional, além de aspectos biográficos vinculados à trajetória de produção artística.

De forma complementar e em diálogo com o resultado das entrevistas com o ator chave, foram elaboradas questões extraídas dessas entrevistas e enviadas a outros quatro artistas educadores que se destacam no cenário nacional e latino americano. Nessa abordagem, foi utilizado o roteiro semiestruturado, contendo perguntas relacionadas às práticas artísticas e educacionais, bem como em relação ao conceito de imagem utilizado por cada um deles.

Os argumentos que justificam o uso da entrevista em profundidade não se referem apenas à exploração do ponto de vista do ator chave, cuja inserção no contexto da arte educação é notória. Situam-se na contramão das críticas que circundam em torno do fato da entrevista ser um processo de interação social, que, supostamente, dotam de parcialidade a investigação.

A expressão subjetiva das entrevistas e dos discursos orais, como produções intersubjetivas, como uma construção coletiva do pensamento, permitem o compartilhamento reflexivo. Possibilitam que 0 entrevistado proponha seus próprios insights, o que pode ampliar e/ou orientar futuras investigações ${ }^{130}$. Algo que vai além de uma lógica propedêutica fundamentada na hierarquização e distinção de sujeitos e conteúdo.

$\mathrm{Na}$ entrevista em profundidade, à medida que um sujeito relata um acontecimento, ou reflete sobre algum tema que Ihe é peculiar, o entrevistador não apenas escuta as palavras que refletem orientações, mas captura afetos que dão indícios de como o entrevistado está percebendo o mundo e o está relacionando ao fenômeno abordado. Já nas entrevistas semiestruturadas, nas quais são seguidos roteiros compostos por questões abertas, também é possível mesclar a condução conversacional, criando espaços para que o entrevistado possa manifestar mais livremente suas interpretações.

Nesse contexto, "os sujeitos/objetos de investigação, primeiramente, são constituídos como componentes do objeto de estudo"131. No campo, este

\footnotetext{
130 YIN, Robert k. op. cit. p.30 et seq.

${ }^{131}$ MINAYO, Cecília de Souza (org); GOMES. Suely Ferreira Deslandes Romeu. op. cit. p. 62 et seq.
} 
argumento de Minayo engloba todas as abordagens e coleta de dados, articulando um processo de relação intersubjetiva,

[...] de interação social com o pesquisador, daí resultando num produto compreensivo que não é a realidade concreta e sim uma descoberta construída com todas as disposições em mãos do investigador: suas hipóteses e pressupostos teóricos, seu quadro conceitual e metodológico, suas interações suas entrevistas e observações, suas interrelações com os colegas de trabalho ${ }^{132}$.

As entrevistas forneceram base de dados de duas naturezas. As primeiras referem-se aos dados coletados por meio de outras fontes, como catálogos, entrevistas em periódicos, anais de congressos e livros publicados pelo ator chave. As segundas, que são objetos fundamentais da pesquisa qualitativa, subsidiaram informações diretamente no diálogo com o sujeito entrevistado e, dessa relação, brotaram as reflexões sobre sua realidade vivida. São representações da realidade, crenças e formas muito específicas de pensar e agir (conscientes e inconscientes), que somadas à experiência em contextos, espaços e tempos distintos, espelham as relações e dinâmicas do próprio campo da arte.

Do ponto de vista técnico, para conceder atenção a cada palavra, a cada expressão, todas as entrevistas com o ator chave foram registradas por meio de vídeo (Ver Anexo 1). O tratamento rigoroso dos protocolos e a utilização de recursos tecnológicos, tiveram seus fundamentos no trabalho desenvolvido por Meihy \& Holanda ${ }^{133}$ e Duarte ${ }^{134}$. Esta orientação definiu os preceitos firmados no projeto, tanto na especificação dos espaços e tempo de duração dessas interações, quanto do processo de transcrição das falas/expressões e confecção das fichas de acompanhamento e controle do projeto (Quadro 01). Material que foi transformado em textos e notas com base nos critérios definidos pelos procedimentos da história oral (Quadro 02) e forneceram subsídio para o diálogo com o campo documental, teórico e registros derivados de outras incursões em campo.

\footnotetext{
132 Ibidem p.63.

${ }^{133}$ MEIHY, José Carlos Sebe Bom. HOLANDA, Fabíola. História Oral - Como fazer, como pensar. São Paulo: Contexto, 2007.

${ }_{134}$ DUARTE, R.. Entrevistas em pesquisas qualitativas. IN: Educar, Curitiba, n.24, p. 213-224, 2004.
} 
Quadro 01: relação de entrevistas com o ator chave.

\begin{tabular}{|l|l|}
\hline Data da entrevista/ local & Tempo de entrevista \\
\hline $\begin{array}{l}\text { 07/04/2014 - Residência de Lucimar Bello Frange, Rua } \\
\text { Aleixo Garcia, } 51 \text { - Vila Olímpia, São Paulo, SP }\end{array}$ & 2 horas \\
\hline $\begin{array}{l}\text { 16/05/2104 - Residência de Lucimar Bello Frange, Rua } \\
\text { Aleixo Garcia, } 51 \text { - Vila Olímpia, São Paulo, SP }\end{array}$ & 2 horas \\
\hline $\begin{array}{l}\text { 16/06/2014 Residência de Lucimar Bello Frange, Rua Aleixo } \\
\text { Garcia, } 51 \text { - Vila Olímpia, São Paulo, SP }\end{array}$ & 2 horas \\
\hline $\begin{array}{l}\text { 05/09/2014 - Residência de Lucimar Bello Frange, Rua } \\
\text { Aleixo Garcia, } 51 \text { - Vila Olímpia, São Paulo, SP }\end{array}$ & 2 horas \\
\hline $\begin{array}{l}\text { Dia: 05 de setembro de 2014 - (a entrevista teve sua } \\
\text { continuidade com a visita à Bienal Internacional de São } \\
\text { Paulo) SP. }\end{array}$ & $\begin{array}{l}\text { 2 horas na Bienal Internacional } \\
\text { de São Paulo. }\end{array}$ \\
\hline
\end{tabular}

Quadro 02: Tratamento das entrevistas com base nos procedimentos da história oral.

\begin{tabular}{|l|l|}
\hline Transcrição & $\begin{array}{l}\text { Segundo Meihy (2007) este conceito refere-se à uma mutação, "ação } \\
\text { transformada, ação recriada" de uma coisa em outra (p.131). Constitui-se } \\
\text { em uma mesma fonte, a palavra, que ao ser destituída de sua condição } \\
\text { etérea ganha a dimensão plástica na grafia. Envolve além da compreensão } \\
\text { do que foi falado, suas nuanças expressas pela fala do corpo, os gestos, } \\
\text { os silêncios e as ponderações, os juízos críticos que reforçam as questões } \\
\text { identitárias; }\end{array}$ \\
\hline $\begin{array}{l}\text { Edição das } \\
\text { entrevistas }\end{array}$ & $\begin{array}{l}\text { Os textos foram editados em arquivos renomeados, tendo em vista reduzir } \\
\text { frases excessivamente coloquiais, interjeições, repetições e outros } \\
\text { elementos comunicacionais que não contribuíssem para a abordagem do } \\
\text { objeto, conforme os objetivos de pesquisa definidos; }\end{array}$ \\
\hline $\begin{array}{l}\text { Análise } \\
\text { interpretação }\end{array}$ & $\begin{array}{l}\text { Foram definidas categorias de análise, consideradas as unidades de } \\
\text { significação, que guiaram o processo de fragmentação para análise e } \\
\text { interpretação. }\end{array}$ \\
\hline
\end{tabular}

Fonte: Meihy e Holanda, Op.Cit.; Duarte, Op. Cit.

É importante ressaltar que o propósito de apropriação dos procedimentos da história oral, no estudo de caso, não foi dar ênfase à abordagem da história de vida como fio condutor. Além disso, o conjunto das práticas que envolvem entrevistado e entrevistador foi considerado, nesta investigação, como 
colaborativo ${ }^{135}$. As situações de entrevista sempre possibilitam circunstâncias delicadas, por isso não se reduzem à cooperação. Envolvem uma dinâmica que deve ser dotada de respeito pelos dissensos, o que torna possível garantir o registro das experiências, mesmo quando o interlocutor expressa ideias divergentes às do entrevistador.

Conforme foram conduzidos os encontros, com muito cuidado, procurouse ativar o processo de rememoração do entrevistado de forma a tangenciar as narrativas de vida e as questões biográficas por meio de questões teóricas, acontecimentos, questões artísticas e suas relações com a educação. Na etapa de análise e interpretação, as falas foram fragmentadas e reagrupadas conforme as categorias de análise, já apresentadas. Além da articulação dessas unidades foi realizado o seu cruzamento com os fundamentos teóricos, baseando 0 processo interpretativo.

Adicionalmente, de acordo com as categorias estabelecidas, foram realizados cruzamentos também com as abordagens fornecidas por quatro artistas entrevistadas. Todas elas possuem o perfil de artistas educadoras, o que permitiu ampliar o diálogo e aprofundar a compreensão acerca dos problemas interpostos na execução da pesquisa. Na utilização das falas delas, optou-se pela codificação, em detrimento da nominação, como recurso protocolar de preservação dos entrevistados. (Ver Quadro 03)

Quadro 03: Entrevistas complementares artistas educadores

\begin{tabular}{|l|l|l|}
\hline $\begin{array}{c}\text { CODIFICAÇÃO } \\
\text { IDENTIFICAÇÃ̃o }\end{array}$ & NOME DAS ARTISTA & \multicolumn{1}{|c|}{ BREVE APRESENTAÇÃo } \\
\hline AE1 & Stela Barbieri & $\begin{array}{l}\text { Artista, curadora e e } \\
\text { consultora nas áreas de } \\
\text { educação, artes e literatura }\end{array}$ \\
\hline AE2 & Cláudia França & $\begin{array}{l}\text { Artista, educadora, Doutora } \\
\text { em Artes pela UNICAMP }\end{array}$ \\
\hline AE3 & Rosana Paulino & $\begin{array}{l}\text { Artista, educadora, Doutora } \\
\text { em Artes Visuais pela } \\
\text { Universidade de São Paulo }\end{array}$ \\
\hline
\end{tabular}

135 Ibidem, p.120. Para Mehy e Holanda, dentro do conceito de colaboração caba o de cooperação. Colaboração é maior que cooperação, mas a cooperação perde sentido depois de estabelecido o texto com sua devida autorização. 


\begin{tabular}{|l|l|l|}
\hline AE4 & Marcela Tiboni & $\begin{array}{l}\text { Artista, Mestre em Estética e } \\
\text { História da Arte pelo Museu } \\
\text { de Arte Contemporânea da } \\
\text { Universidade de São Paulo }\end{array}$ \\
\hline
\end{tabular}

Fonte: Entrevistas realizadas pelo autor

\subsection{O terceiro meridiano: observações direta e participante}

O terceiro e último vetor da pesquisa se apoiou no processo de observação direta e participante, fundamentada na pesquisa etnográfica. Embora haja muitas formas e técnicas de realizar a investigação de campo, dois são os instrumentos fundamentais dessa espécie de trabalho: a observação e a entrevista. Enquanto a segunda é construída, como discutido anteriormente, sobre a relação com interlocutores, a primeira é edificada sobre tudo aquilo que não é dito, mas pode ser visto e captado.

Tal como realizado na pesquisa documental/iconográfica, houve dois momentos dessa incursão observacional. $O$ primeiro deles também visou 0 aprimoramento da problemática de pesquisa, compreendendo o campo. Nele foram acompanhados grupos de professores e estudantes, bem como visitas técnicas aos espaços expositivos. Esse procedimento de investigação é apropriado, particularmente, quando a pretensão é descrever comportamentos em contextos complexos. Um caminho adequado quando a pretensão é considerar a influência do contexto de ocorrência do fenômeno em estudo para trabalhar com base em múltiplas fontes de evidência ${ }^{136}$. No segundo momento, este sim objeto de análise dentro do estudo de caso, foi definido um trabalho de maior amplitude, realizado pelo ator chave, sobre o qual foram capturados dados por meio da observação direta participante. Compuseram esses dados, os registros em caderno de campo, fotográficos e videográficos do trabalho Desenhos de Comer, considerado seu caráter síntese no que tange à abordagem didático pedagógica do ator chave.

${ }^{136}$ YIN, Robert K. Estudo de caso. Planejamento e métodos. Tradução: Ana Thorell; 4 ed.Porto Alegre: Bookman, 2010, passim. 
Cabe então, fazer uma diferenciação nessa técnica com base nas incursões. Não seria adequado lançar mão apenas da tipologia observação direta nesse caso. Em vários momentos, foi utilizada a observação definida como invasiva ${ }^{137}$, um tipo de técnica que recorre aos sentidos na obtenção de alguns aspectos da realidade. Não se caracteriza apenas em ver e em ouvir, mas em estimular, de maneira sutil, acontecimentos que ampliam a compreensão do fenômeno. Nesse caso, não há a incorporação ao grupo, mas uma maneira de se colocar em relação a ele e em algumas situações que, instigam os atores a ações específicas. A própria forma de registro é uma delas. Quando o pesquisador se posiciona a fim de capturar uma determinada situação, a maneira como o faz e o lugar que ocupa em relação ao grupo interferem em suas falas e ações.

No primeiro momento foram utilizadas a observação direta e, por vezes, a intitulada como invasiva. O Quadro 04 sistematiza as ações que foram planejadas e controladas. Foram utilizados instrumentos de coletas de dados com o objetivo específico de compreender o comportamento, as impressões e as narrativas dos professores e estudantes nos contextos da arte contemporânea. A mesma técnica foi utilizada para o registro de visitações técnicas, em que o objetivo era registrar as exposições e observar o público em geral.

Em todas as instituições visitadas o procedimento foi similar. Foi realizado o acompanhamento dos mediadores na recepção de estudantes e professores, e, posteriormente, feita a apresentação como pesquisador com o intuito de conhecer seus processos, recursos e abordagens sobre as práticas artísticas contemporâneas e sua relação com o campo educacional (Quadro 05).

\footnotetext{
${ }^{137}$ O termo observação invasiva foi cunhado pelo autor. Não há essa tipologia no estudo de caso. O termo mais próximo é definido como observação direta intensiva, adotado nas entrevistas e como um teste de atitudes.
} 
Quadro 4: Fichas de acompanhamento e registro

\begin{tabular}{|c|c|c|c|}
\hline DATA & LOCAL & DURAÇÃO & DESCRIÇÃO \\
\hline $19 / 09 / 2013$ & $\begin{array}{ll}\text { São } & \text { Paulo } \\
\text { (SP) }\end{array}$ & $1: 30$ & $\begin{array}{l}\text { Participação na visita exclusiva para } \\
\text { professores oferecida pelo Educativo da Bienal } \\
\text { Internacional de São Paulo }-30 \times \text { bienal } \\
\text { transformações na arte brasileira da } 1 \text { à } 30^{\circ}\end{array}$ \\
\hline $05 / 09 / 2014$ & $\begin{array}{ll}\text { São } & \text { Paulo } \\
\text { (SP) } & \end{array}$ & $1: 30$ & $\begin{array}{l}\text { Participação na visita exclusiva para } \\
\text { professores oferecida pelo Educativo da Bienal } \\
\text { Internacional de São Paulo - } 3 \text { łaienal - Como } \\
\text { Aprender de Coisas que não existem. }\end{array}$ \\
\hline 2013 & $\begin{array}{l}\text { Porto } \\
\text { Alegre } \\
\text { (RS) }\end{array}$ & $2: 00$ & $\begin{array}{l}\text { Acompanhamento de ações educativas e } \\
\text { discussões na Bienal Mercosul. }\end{array}$ \\
\hline 2013 & $\begin{array}{l}\text { Curitiba } \\
\text { (PR) }\end{array}$ & $2: 00$ & $\begin{array}{l}\text { Acompanhamento de ações educativas e } \\
\text { discussões na Bienal de Curitiba. }\end{array}$ \\
\hline 2014 & $\begin{array}{l}\text { São Paulo } \\
\text { (SP) }\end{array}$ & $2: 00$ & Pinacoteca do Estado de São Paulo. \\
\hline 2014- 2015 & $\begin{array}{ll}\text { São Paulo } \\
\text { (SP) }\end{array}$ & $2: 30$ & Instituto Cultural Itaú. \\
\hline 2015 & $\begin{array}{l}\text { São Paulo } \\
\text { (SP) }\end{array}$ & $3: 00$ & Instituto Tomie Ohtake. \\
\hline 2014- 2015 & $\begin{array}{l}\text { São Paulo } \\
\text { (SP) }\end{array}$ & $2: 00$ & Paço das Artes/Cidade Universitária-USP. \\
\hline
\end{tabular}

Fonte: Acervo da pesquisa

Quadro 5: Visitas técnicas, observações e registros de atividades do público

\begin{tabular}{|l|l|l|}
\hline \multicolumn{1}{|c|}{ Instituição - Local } & \multicolumn{1}{|l|}{ Descrição da atividade } & \multicolumn{1}{c|}{ Mês - Ano } \\
\hline Bienal Internacional de São Paulo & $\begin{array}{l}\text { Participação como } \\
\text { professor em convite } \\
\text { oferecido pela Bienal }\end{array}$ & Setembro de 2013 \\
\hline $\begin{array}{l}\text { Museu Calouste Gulbenkian. } \\
\text { Cidade de Lisboa, Portugal. }\end{array}$ & $\begin{array}{l}\text { Observação e diálogo com } \\
\text { o setor educativo do } \\
\text { Museu. }\end{array}$ & Novembro 2013 \\
\hline $\begin{array}{l}\text { Museu Municipal da cidade de } \\
\text { Faro. Cidade de Faro, Portugal. }\end{array}$ & $\begin{array}{l}\text { Observação e diálogo com } \\
\text { o setor educativo do } \\
\text { Museu. }\end{array}$ & Novembro 2013 \\
\hline $\begin{array}{l}\text { Galeria de Arte Contemporânea do } \\
\text { Centro de Investigação em Artes e } \\
\text { Comunicação da Universidade do }\end{array}$ & $\begin{array}{l}\text { Observação e registro de } \\
\text { atividades do público. }\end{array}$ & Novembro 2013 \\
Algarve. Cidade de Faro, Portugal. & & \\
\hline $\begin{array}{l}\text { Fundação PROA - Centro de Arte } \\
\text { Contemporânea de Buenos Aires, } \\
\text { Argentina. }\end{array}$ & $\begin{array}{l}\text { Observação e diálogo com } \\
\text { os mediadores. }\end{array}$ & Dezembro 2013 \\
\hline
\end{tabular}




\begin{tabular}{|c|c|c|}
\hline Bienal Internacional de São Paulo & $\begin{array}{l}\text { Participação } r \text { como } \\
\text { professor em convite } \\
\text { oferecido pela Bienal }\end{array}$ & Setembro de 2014 \\
\hline $\begin{array}{lll}\text { Laboratório de } & \text { Processo } \\
\text { Formativo / SP } & & \end{array}$ & $\begin{array}{l}\text { Curso - Atos de mudança: } \\
\text { praticar desmanches. } \\
\text { Ministrado por Lucimar } \\
\text { Bello Frange e pela } \\
\text { filósofa, terapeuta e } \\
\text { educadora Regina Favre }\end{array}$ & Outubro 2014 \\
\hline $\begin{array}{l}\text { Encontro } \quad \text { Nacional de } \\
\text { Pesquisadores em } \\
\text { (BH/MG) Plásticas } \\
\text { Artísticos }\end{array}$ & $\begin{array}{l}\text { Apresentação de simpósio } \\
\text { e debate com as } \\
\text { professoras Lucimar Bello } \\
\text { e Leda Guimarães }\end{array}$ & Novembro 2014 \\
\hline $\begin{array}{l}\text { PAE - Estágio Supervisionado. } \\
\text { Disciplina História do Ensino da } \\
\text { Arte I. Supervisão da professora } \\
\text { Dra. Maria Christina de Souza } \\
\text { Lima Rizzi (ECA/USP - SP) }\end{array}$ & $\begin{array}{l}\text { Estágio supervisionado. A } \\
\text { atividade em questão foi } \\
\text { extremamente produtiva } \\
\text { no processo de } \\
\text { observação dos } \\
\text { estudantes em situações } \\
\text { de avaliação pessoal e em } \\
\text { grupo de questões } \\
\text { referentes ao objeto de } \\
\text { pesquisa. Nesse contexto } \\
\text { pudemos efetivar muitas } \\
\text { anotações no diário de } \\
\text { campo e utilizá-las na } \\
\text { consolidação das análises }\end{array}$ & 2014 \\
\hline $\begin{array}{l}\text { Fundação PROA - Centro de Arte } \\
\text { Contemporânea de Buenos Aires, } \\
\text { Argentina. }\end{array}$ & $\begin{array}{l}\text { Observação e diálogo com } \\
\text { os mediadores. }\end{array}$ & Fevereiro 2015 \\
\hline $\begin{array}{l}\text { Museo de Arte Latinoamericano de } \\
\text { Buenos Aires - MALBA, Argentina. }\end{array}$ & $\begin{array}{l}\text { Observação e diálogo com } \\
\text { os mediadores. }\end{array}$ & Fevereiro 2015 \\
\hline $\begin{array}{l}\text { Centro Cultural Recoleta, Buenos } \\
\text { Aires, Argentina. }\end{array}$ & $\begin{array}{l}\text { Observação e registro de } \\
\text { atividades do público. }\end{array}$ & Fevereiro 2015 \\
\hline $\begin{array}{l}\text { Espacio de Arte Contemporáneo } \\
\text { de Montevidéu, Uruguai. }\end{array}$ & $\begin{array}{l}\text { Observação e registro de } \\
\text { atividades do público. }\end{array}$ & Dezembro 2015 \\
\hline $\begin{array}{l}\text { Museo de Arte Contemporáneo de } \\
\text { Montevidéu }\end{array}$ & $\begin{array}{l}\text { Observação e registro de } \\
\text { atividades do público. }\end{array}$ & Dezembro 2015 \\
\hline
\end{tabular}

Fonte: Acervo da pesquisa 
No segundo momento, relacionado ao trabalho Desenhos de Comer, em seu desenvolvimento no mês de junho de 2016, optou-se pelo processo de observação participante, no qual o investigador deixa de ser espectador. Houve o envolvimento com o fenômeno em um evento que nutriu a pesquisa em termos de interações verbais e não verbais. Esse trabalho de campo, cujos fundamentos também estão na etnografia ${ }^{138}$, visou intensificar a situação de estudos. Facilitou a compreensão das regras e comportamentos a elas subsequentes, principalmente, no que se refere aos processos artísticos, sobre a relação com a imagem e sobre as mobilizações didático pedagógicas em operação.

É comum que o pesquisador, no território da observação participante, fique à deriva. Não é esperado pelo grupo, desconhece, a priori, as relações que marcam a hierarquia de poder e a estrutura e funcionamento das atividades propostas. É um contexto inquieto que carece, sobretudo, que compreenda que não têm controle das situações. A contrapartida dessa situação de incerteza está na riqueza da aplicação do método. $O$ trabalho de campo participante permitiu a aproximação da realidade sobre a qual foram formulados os questionamentos de pesquisa. Dessa relação nasceu um conhecimento empírico que, de outra maneira não se realizaria, a abrangência, na prática, do recorte teórico correspondente ao objeto de investigação.

O contato direto, por meio da organização e participação da execução do "Desenhos de Comer" na cidade de Curitiba possibilitou, ao mesmo tempo, afastamento e proximidade, como também uma visão mais abrangente dos processos. Se de um lado, foi possível a observância das peculiaridades expressas nos tempos, afetos, referências e memórias específicas dos participantes, de outro, pode-se constatar o que Guattari define como uma subjetividade coletiva. Aquela produzida no plural, pela máquina social ${ }^{139}$.

A relação direta com seus interlocutores no espaço social de pesquisa, modifica o próprio contexto, pois, interfere nele e por ele é também modificado. Essa transformação nos proporcionou estar no lugar do outro, o que seria

${ }^{138}$ ROCKWELL, E. "Etnografia e teoria na pesquisa educacional". In: Ezpeletta, J. e Rockwell, E. Pesquisa participante. São Paulo, Cortez, 1986.

139 GUATTARI, Félix. Da produção da subjetividade. In: estético. Rio de Janeiro: Ed.34, 1992. 
improvável se a investigação tivesse sido conduzida por meio de modelos fechados e antecipadamente padronizados.

A observação direta participante representou um método altamente pertinente para a abordagem almejada nessa pesquisa, porque possibilitou obter o máximo de conhecimento de forma dinâmica. Sua maior vantagem está em gerar informações durante o desenrolar do fenômeno, além de permitir a vivência pessoal por parte do pesquisador. Em termos operacionais, a experiência relativa ao Desenhos de Comer também foi documentada em vídeo e sob forma de anotações pessoais. Estas observações foram transcritas em um relatório único, que, posteriormente, foi reorganizado por categorias também relacionadas aos objetivos de pesquisa.

\subsection{A triangulação dos dados}

A primeira questão a ser levantada sobre este tópico, é esclarecer que em uma pesquisa qualitativa, a análise e interpretação não têm como finalidade, como afirma Minayo, "contar opiniões de pessoas"140. O foco é explorar as representações sociais que o tema investiga. No que se refere ao estudo de caso, existe um fator de complexificação, que diz respeito ao uso de mais de um método para a abordagem do objeto de pesquisa. Cada um deles possui instrumentos de análise mais adequados e formas particulares de análise e interpretação. A combinação dos resultados exige, no entanto, uma estratégia conhecida como triangulação de dados ${ }^{141}$.

O tratamento prévio dos dados foi crucial para a realização do procedimento de triangulação. O processo de análise e interpretação por cada método escolhido propiciou a configuração de um quadro baseado nas categorias derivadas dos objetivos de pesquisa, sendo elas: prática artística, imagem e processos pedagógicos. Isto posto, tornou-se exequível o cruzamento dos resultados da análise de documentos, das entrevistas e da observação participante realizada no trabalho Desenho de Comer (Ver Figura 21).

\footnotetext{
${ }^{140}$ MINAYO, Cecília de Souza (org); GOMES. Suely Ferreira Deslandes Romeu. op. cit. p. 85 et seq.

${ }^{141}$ YIN, 2010. Op.Cit; MINAYO, 2015. Op. Cit.
} 


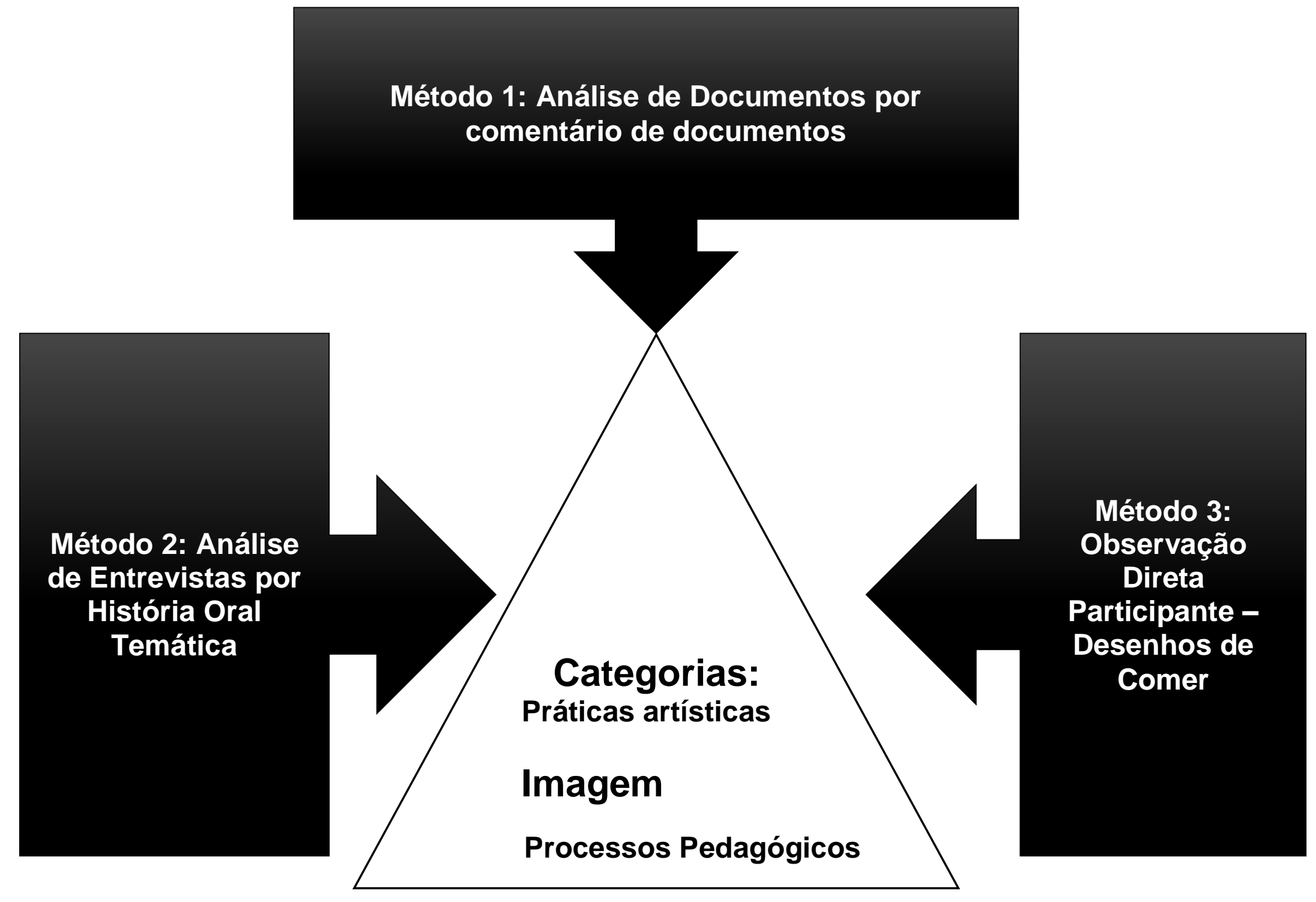

Figura 21. Esquema da Triangulação de dados. Fonte: Dados de Pesquisa. Organização Própria 


\title{
Capítulo 3: Uma Linha no Mundo - Estudo de caso sobre a artista e educadora Lucimar Bello Frange
}

3.1 Trajetória artística e educadora de Lucimar Bello: análise e interpretação documental

\author{
Poema n.ossos \\ n.ossos \\ n.ossos \\ n.ossos \\ n.ossos \\ n.ossos \\ n.ossos \\ n.ossos \\ (Lucimar Bello. 10.01.13)
}

_ O que sustenta nossas escolhas? Temos ciência de que nossas práticas e com.vívios na arte e na educação sempre dizem algo às subjetividades. Linha no mundo faz referência à trajetória de Lucimar Bello Frange, abriga o sentido de sua aproximação com a arte por meio da linguagem do desenho. Anuncia as faturas de um trabalho que se define por uma estética do cotidiano, na qual, a partilha daquilo que não nos pertence e, ao mesmo tempo, é comum e propriedade de todos nós, define n.ossos encontros como um lugar de criação. Dessa relação somos levados uns aos outros em jornadas de vida, em gestos, silêncios, palavras, cores e imagens/formas de alteridade que sustentam o corpo da arte nas ações formativas.

Marcado por um forte investimento na relação entre arte e cotidiano, na corporeidade, no encontro com o outro, no exercício da alteridade pela ativação de convívios em torno da prática artística, o trabalho desenvolvido por Lucimar Bello Frange, constituiu-se, nas últimas décadas, como referência no campo educacional da arte. Sua trajetória como artista e no ensino da arte, além da ressonância das vozes de artistas e educadores que fizeram e fazem a história do ensino da arte no Brasil (Noemia Varela, Augusto Rodrigues e Ana Mae 
Barbosa), agrega as vozes de tantos outros educadores e artistas que lhe foram e são próximos em seus processos de formação.

Situando-se nas rupturas contemporâneas, sem perder o profícuo diálogo com as imagens da história da arte, como fonte estruturante das questões estéticas, as incursões da artista, educadora e pesquisadora articulam a atividade criativa e formativa em suas tangências, não apenas com a dinâmica sociocultural, mas, sobretudo, com os processos de subjetivação, que por meio da experiência com a arte dão sentido plástico à existência humana.

Dessa forma, para que se possa abordar a trajetória da artista, nessa primeira parte da análise do estudo de caso, faz-se necessário compreender que, na coerência de sua produção, tanto na arte, como na educação, há um contínuo, um processo no qual não há como desvincular a práxis artística dos contornos que delineiam as ações no campo educacional.

As categorias típicas do cotidiano com as quais trabalha, as formas elementares da vida humana ${ }^{142}$ : habitar, passear, trabalhar, conversar e comer são referentes, e, ao mesmo tempo, elementos agenciadores das experiências que fazem a ponte entre as questões históricas da arte, da educação e das capacidades de "sentir o mundo, de senti-lo organizadamente, conferindo uma ordem primordial, um sentido"143.

Assim, a cronologia da investigação, não segue a linearidade temporal de maneira rígida, mas a toma como recortes no tempo e no espaço das ações poéticas e contextos políticos. Conecta as práticas artísticas, os modos de pesquisa da imagem e as proposições no campo educacional em sua forma espiral, como um fluxo da percepção, como condição necessária para que não se compreenda sua trajetória apenas como uma forma de acúmulo, causas e efeitos, mas como contextos em que sua liberdade ficcional de habitar tempos e espaços distintos de significação criam relações entre memória, afeto e realidades, desafiando o poder representativo da imagem.

\footnotetext{
142 KUJAWSKI, Gilberto de Mello. A crise do século XX. São Paulo: Ática, 1988. ${ }^{143}$ DUARTE JÚNIOR. João Francisco. A montanha e o videogame: Escritos sobre educação. São Paulo: Papirus, 2010.
} 


\subsubsection{Novos contextos, outras formas sem fôrmas}

Quando Lucimar Bello Frange, de fato, adentrou ao universo da arte, ainda nos anos 1960-1970, contexto em que havia uma reação evidente à capitalização cultural aos processos de privatização da sociedade pela lógica implementada por governos neoliberais do período, a arte estava passando por um processo de transformação ${ }^{144}$. As práticas artísticas se deslocavam fortemente de um plano específico baseado no confinamento do atelier, para procedimentos que buscavam a configuração de espaços colaborativos e abertos à participação. Uma virada etnográfica que retomava as questões inauguradas por Benjamin no texto "o artista como produtor"145, e que na leitura subsequente de Hall Foster, "The artist as ethnographer.,", 146 aparecia como a efetivação do empreendimento de movimentos de vanguarda do início do século $\mathrm{XX}$, como o surrealismo, o dadaísmo e o construtivismo, nas experimentações estéticas que tinham seus rebatimentos na produção da segunda metade do século.

No influente texto de Benjamin, endereçado a um público específico no âmbito artístico e literário, o foco estava voltado para necessidade do engajamento dos artistas, no sentido de sua atenção às transformações dos meios de produção. Ou seja, da maneira como se apropriam, em seus modos de operar, de objetos materiais de toda ordem que estão envolvidos, direta ou indiretamente, nas práticas artísticas. O referido texto trazia a distinção entre os

144 É importante destacar que entre os anos de 1920 e 1970, no contexto brasileiro, as experiências no âmbito do ensino e aprendizagem da arte eram sustentadas pela estética modernista e tinham como base a tendência escolanovista. A ênfase dos procedimentos da escola tradicional, passaram a ser redimensionadas com foco nos processos de desenvolvimento do estudante e sua criação. No final dos anos 60 e na década seguinte, houve uma tentativa de aproximação entre as manifestações artísticas que aconteciam fora do ambiente escolar e o que era ensinado dentro dele. Nesse período, destacam-se os festivais da canção e as novas experiências teatrais, com grande mobilização por parte dos estudantes. No entanto, apesar de tal efervescência no campo cultural, até os anos 80 , quando foi constituído o movimento Arte-Educação, que estimulou as discussões e a valorização dos docentes em arte, pode-se dizer que que a relação entre o ensino da arte e as práticas artísticas ainda se sustentavam entre a aprendizagem reprodutiva da escola tradicional e o fazer expressivo da escola novista.

${ }^{145}$ BENJAMIN, Walter. O autor como produtor. In: A modernidade. Obras escolhidas de Walter Benjamin, [edição e tradução de João Barrento], Lisboa, Assírio \& Alvim, 2006, pp. 271-293. O subtítlo do texto "Der Autor als Produzent (O autor como produtor) supostamente foi escrito para uma conferência no Instituto para o estudo do fascismo em Paris, no ano de 1934. No entanto, sua primeira publicação ocorreu somente 26 anos após sua morte, em 1966.

${ }^{146}$ FOSTER, Hal. The artist as ethnographer. In: The return of the real. 3. ed. Cambridge; London: MIT Press, 1999, pp. 171-204. 
artistas que se preocupavam com as questões sociais apenas em nível de suas convicções e os que se engajavam como atores sociais ${ }^{147}$ na condição de produtores, a fim de propiciar condições e possibilidades para que o público também o fizesse.

As mudanças decorrentes das inovações técnicas e sua apropriação estética traziam mais que um caráter mediador sob o qual os artistas deveriam calcar suas poéticas, empenhava uma função pedagógica da arte. Não em um sentido de condução moral, mas de estímulo aos outros produtores e ao público como agente ativo. A crítica do contexto encontrava-se, portanto, na apropriação alienada dos meios de produção, bem como em sua utilização que vinha se transformando em moda. Além disso, estava voltada para seus efeitos, considerando que, nessa perspectiva, acentuariam a passividade do público, desconstruindo a possibilidade de que este assumisse uma posição perante o acontecimento $^{148}$.

Os estudos de Benjamin sobre a modernidade do século XIX, de certa forma, antecipavam os processos de transformação que repercutiriam nas décadas seguintes, dialogando, profundamente, com as práticas artísticas dos anos 1960. Para o autor, o avanço da indústria cultural e o periodismo eram os agentes para destruição generalizada da experiência ${ }^{149}$. No entanto, em seu

\footnotetext{
147 O termo "ator social" foi utilizado por Lucimar Belo Frange em muitas das entrevistas concedidas ao referir-se ao seu trabalho como artista e educadora.

148 BENJAMIN, Walter Ibidem, 2006, p.128. É importante destacar que ao ressaltar a força revolucionária desses movimentos de vanguarda, Benjamim destaca sua potência em submeter a arte à prova de autenticidade.

${ }^{149}$ A título de exemplo é possível destacar uma experiência registrada durante o processo de investigação empírica, que evidencia de maneira relevante essas questões, principalmente no que tange à informação como elemento que percorre o todo comunicacional, disseminando valores no pensamento sobre arte e, por conseguinte, nas práticas de ensino e aprendizagem da arte. Dois eventos simultâneos ocorreram em São Paulo: uma mostra/retrospectiva com cerca de 300 obras (pinturas, desenhos, esculturas e instalações) da artista suíça Mira Schendel na Pinacoteca do Estado; uma exposição da artista japonesa Yauoi Kusama intitulada "Obsessão infinita", que contou com 100 obras que cobrem sua produção entre 1949 a 2012, no Instituto Tomie Ohtake. A relevância desses eventos, no processo de investigação, teve como motivação o fato de ambos serem retrospectivas de artistas com trajetórias que se destacam na história da arte contemporânea internacional. A simultaneidade dos eventos possibilitou comparar a resposta do público a uma chamada para a "experiência" com o trabalho de duas artistas desconhecidas do público por motivos diferentes. Se na Pinacoteca do Estado, a ausência do público era notória, no Instituto Tomie Ohtake a mostra se apresentou como um evento de massa, o que ocasionou a formação de grandes filas durante todo o tempo da exposição. Vale destacar que esta exposição, no Brasil, contou com um público de 1,7 milhões de pessoas, segundo dados da impressa. O que mostra que, o que se define como sistema ou circuito das artes não é algo paralelo ao universo das mídias, mas um contexto cultural no qual as artes estão inseridas. Não se trata de emitir valores sobre os referidos trabalhos. Em que pese a importância da artista japonesa como pioneira em instalações e como vanguarda em performance nos anos
} 
conhecido ensaio em que trata da obra de arte e sua reprodutibilidade técnica, abre algumas frestas para que se possa pensar a experiência, e os modos de relação entre a arte e a sociedade no capitalismo com alto desenvolvimento tecnológico, como uma via de mão dupla.

Se a técnica da reprodução da arte, como pensava Benjamin, separa aquilo que foi reproduzido da tradição, ela também permite que o receptor tenha acesso a ela em outras circunstâncias. O desenvolvimento das forças de produção e comunicação impulsionavam e exerciam uma função contraditória. Viabilizavam a heterogeneidade de sentidos, não apenas em relação aos produtores, mas aos receptores. Nesse sentido, haveria uma recepção, cujas ressonâncias teriam seu eco no universo popular, como um momento de visibilidade e presença desses grupos. Trata-se, como apontava Dewey, de pensar os objetos sociais - crenças e hábitos, em sua íntima relação com objetos físicos. Um processo comunicacional em que a arte não equivale à descrição de um ser ou de um dever ser, mas apresenta-se como um meio de aumentar as possibilidades de desenvolvimento dos sujeitos e das coletividades.

Esse é um dos motivos pelos quais, nesse contexto, apostava-se na retomada da experiência a partir de condições específicas da arte: "Desfazer a alienação do sensório corporal, restaurar a força instintiva dos sentidos corporais humanos em prol da autopreservação da humanidade"150. Ou seja, da capacidade das práticas artísticas, por meio dos novos meios de produção da imagem, principalmente, a fotografia e o cinema, tornar possível investir o objeto

\footnotetext{
de 1960, a maneira como a exposição/evento/espetáculo foi disseminada pelos sistemas de comunicação, como um drama pessoal e entretenimento, apenas desqualifica e confunde as possibilidades do público estabelecer outras relações mais consistentes com essas práticas artísticas. Em tempo, a retrospectiva de Mira Shendell, que ao lado de Lygia Clark e Helio Oiticica, reinventou a linguagem do modernismo no Brasil e, apesar de ser uma das mais inventivas do pós-guerra, passou quase desapercebida do grande público. Além disso, torna-se evidente que, além das deficiências do sistema educacional, tanto público, quanto privado, em incorporar e articular os raros eventos desse porte às suas estratégias de ação, colaborando, ainda que, pela omissão, para o comportamento do público cuja motivação está diretamente ligada à cultura e ao sistema de consumo. $\mathrm{O}$ que corrobora para que as "imagens que povoam o cotidiano das pessoas permaneçam como um sistema de signos desconhecidos", como afirma Barbosa. BARBOSA. Ana Mae. Tópicos Utópicos. Belo Horizonte: C/arte, 1998. p.137.

150 BUCK-MORSS, Susan. Estética e anestética: uma reconsideração de A obra de arte de Walter Benjamin. In: Benjamin e a obra de arte. Técnica, imagem, percepção/ Walter Benjamin [et al.]; trad. Marijane Lisboa Vera Ribeiro; org, Tadeu Capistrano. Rio de Janeiro: Contraponto, 2012. p.156.
} 
do poder de revidar o olhar ${ }^{151}$. A experiência que designa uma nova direção na história da percepção ${ }^{152}$.

O conceito de aura em Benjamin, muitas vezes relacionada apenas à obra de arte, é mais extensivo e encontra-se com a perspectiva deweyniana no sentido de incorporar a dimensão estética como uma força motriz e consolidante do processo relacional entre o sujeito e o mundo vivido. Tal encontro com os objetos e as coisas do mundo em sua forma poética significa na arte a busca da antítese a uma modalidade discursiva da crítica de arte que, desde o romantismo, estava vinculada à uma interpretação transcendental da experiência estética em seu vínculo com uma narrativa histórica como princípio explicativo de condutas ${ }^{153}$.

Nessa perspectiva, os produtos da arte não somente perdem o seu status de unicidade e originalidade atrelado a uma determinada dimensão espaciotemporal, como também produzem uma modificação na forma como o receptor e o produtor se relacionam com a ela. Essa nova simbiose (entre práticas artísticas e modos de recepção ativa), vivenciada por Frange em seu período de formação, afetou profundamente o seu campo perceptual e semeou a ideia de que o intercâmbio entre as práticas artísticas e os contextos sociais tem sua efetividade somente quando ...

[...] o corpo e o espaço de imagens se interpenetrarem, dentro dela, tão profundamente que todas as tensões revolucionárias se transformem em inervações do corpo coletivo, e todas as inervações do corpo coletivo se transformem em tensões revolucionárias ${ }^{154}$.

Fica evidente que, nesse contexto, uma das mais importantes mudanças perceptuais diz respeito à presença de uma concepção de experiência na qual as imagens mentais e as imagens reais se interpenetram e edificam uma nova forma de compreender o mundo que colide com a visão linear da história, com

\footnotetext{
151 BENJAMIN. Et. Seq. 139. Nas palavras do autor, essa concepção se baseia na " transferência de uma forma de reação comum na sociedade humana à relação do inanimado ou da natureza com o homem [...] Perceber a aura de uma coisa significa investi-la do poder de revidar o olhar". 152 BENJAMIN. Loc.cit. 1996, p.101.

${ }^{153}$ Nos referimos a uma perspectiva que busca o significado das obras de arte na interseção entre qualidade estética e pertinência histórica no quadro geral da história da arte.

154 Idem. O surrealismo, o último instantâneo da inteligência européia. In: Obras escolhidas. Vol. 1: BENJAMIM, Walter. Magia e técnica, arte e política _ Ensaios sobre literatura e a história da cultura. Trad. Sérgio Paulo Rouanet, 1985, p.21.
} 
as dicotomias de um racionalismo que separa as formas de conhecer o mundo. O que traz à tona a convicção de que é possível, por meio da arte, estabelecer a permuta e a construção de saberes na qual a ética não se separa das práticas artísticas. No plano educacional, deveria ser assumido na perspectiva de que a ação e a consequência devem estar unidas na percepção. "Essa relação é o que confere significado; apreendê-lo é o objetivo de toda compreensão. O âmbito e o conteúdo das relações medem o conteúdo significativo de uma experiência"155.

A espelhamento dessa convicção pode ser encontrada em Joseph Beuys, que pretendia, entre os anos 1960 e 1970, unir a racionalidade científica com a intuição que provém da cultura, para uma possível transformação humana e social. O artista, que exerceu grande influência no período, passou a apropriarse do conhecimento vivido e teórico para construir o conceito ampliado de arte: uma "Escultura Social" como experiência estética e de vida, formadora do processo de organização social ${ }^{156}$. Uma concepção que o coloca na condição de agente constituinte da esfera pública e cuja potência pode ser percebida no trabalho de Frange no projeto de atelier comunitário realizado entre os anos de 1989 e 1990.

Assim, retomando como referência o final dos anos 1980, início da década de 1990, levando em consideração as duas décadas precedentes em função dos contextos históricos e práticas artísticas de influência, dá-se continuidade à trajetória de Frange a partir período que compreende as produções do atelier comunitário $^{157}$. No projeto gestado em 1988, momento em que participava do curso de especialização em "Filosofia - Saber e Poder", realizado na Universidade Federal de Uberlândia, Minas Gerais, entre os anos de 1989 e 1990, a relação "saber e poder" tornou-se objeto de reflexão de seu doutoramento na Escola de Comunicação e Artes da Universidade de São Paulo, em 1993, sob orientação da professora doutora Ana Mae Tavares Bastos Barbosa, com a coorientação do professor doutor David Thistlewood, da Universidade de Liverpool, na Inglaterra.

\footnotetext{
155 DEWEY, John. 2010, pp.122-123.

156 ROSENTHAL, Dália. O elemento material na obra de Joseph Beuys. Dissertação de Mestrado, Universidade Estadual de Campinas. Instituto de Artes- Campinas-SP, 2002.

${ }_{157}$ FRANGE. Lucimar Bello. Por que se esconde a violeta. Esta não é uma concepção de desenho, nem pós-moderna, nem tautológica. São Paulo, ANNABLUME, 1995. p.115.
} 
O trabalho gerou a publicação do livro "Por Que se Esconde a Violeta? Isto não é uma concepção de desenho, nem pós-moderna, nem tautológica", no ano de 1995. Contexto no qual suas preocupações estavam voltadas para as relações entre "arte e poder, arte e poder das imagens, tanto produzidas por nós, quando ingeridas e digeridas ou não por nós" ${ }^{158}$. O que representou, segundo Barbosa ${ }^{159}$, "um exemplo paradigmático do ensino-aprendizagem da arte contemporânea".

O que está contido nesse trabalho, tornando-o imprescindível para compreensão dos percursos de Frange, é ser fruto de uma pesquisa fundamentada em experiências e escritos de artistas e intelectuais. Estrategicamente, a artista transcende os determinismos cronológicos e dialoga com os saberes da arte que se manifestam por meio das práticas artísticas, a fim de dar subsídio para uma concepção de desenho que espelha suas práticas e reflexões no campo formativo. Segundo Frange

[...] são caminhos pelas artes plásticas, por vidas imagizadas (formas-imagens com imaginações), por metodologias e antimetodologias multiculturais, tendo o século XX como paradigma-paradoxo. Arte não reproduz o visível; torna visível (Klee); eu considero o fruidor tão importante quanto o fazedor (Duchamp); arte e ambiental - reunião indivisível de todas as modalidades em posse do artista ao criar e as que surgem na ânsia inventiva do mesmo ou do próprio participador ao tomar contato com a obra (Oiticica). É movimento de desterritorialização de vida, de forma holística se referindo: aquilo que eu sou e aquilo que eu sei e a como eu sei e imagino socialmente. São formas ético-político-estética imagizadas desejadas e realizadas. Isto não é uma concepção de desenho, nem pós-moderna, nem tautológica, vem de muito longe, são encontros apresentáveis e questionáveis em busca de espaços tempos e cores e estruturas plurais.

Como é possível perceber, o que alimenta as investigações de Frange tem origem e compreensão contextual nos movimentos estéticos e sociais. A trajetória da artista, educadora e "atora social", termo autorreferente utilizado em

\footnotetext{
158 Idem, p. 115.

$159 \mathrm{Ibidem}$, p.12. Carta prefácio ao referido livro por Ana Mae Barbosa. É importante destacar que nesse período Ana Mae Barbosa, que também orientou Frange em seu mestrado, acabara de vir da cidade de Recife, Pernambuco, e fundar a primeira Escolinha de Arte de São Paulo, filiada à escola de Augusto Rodrigues (Escolinha de Arte do Brasil-Rio de Janeiro Recife). Contexto enriquecido pela experiência pioneira das Escolas experimentais de São Paulo, os Ginásios Vocacionais, no qual o pintor Maciej Babisnky trabalhou, antes de ir lecionar na Universidade de Brasília, e posteriormente, na Universidade Federal de Uberlândia, Minas Gerais, entre 1979 a 1987, onde foram colegas.
} 
muitos dos seus textos, foi marcada pela expansão dos conceitos tracionais de arte e da inserção de artistas no campo educacional. O que reporta, novamente, aos anos de 1960 e 1970.

Neste período proliferavam, por todo o mundo, manifestos, intervenções e performances. As práticas artísticas passavam a operar em relação a outras demandas sociais e estéticas ${ }^{160}$. Em sintonia com essas transformações, ainda no período de formação acadêmica, Lucimar Bello Frange já explicitava o seu interesse pelo trabalho colaborativo, pelas discussões sobre a mescla de linguagens, pela atuação nos espaços comuns das vivências urbanas que emergiam das ações extensionistas em âmbito universitário.

Sua participação no primeiro Festival de Inverno de Ouro Preto, Minas Gerais, em 1967, não apenas como estudante, mas também como gestora do evento, constituiu um marco importante da trajetória. O festival foi formatado inicialmente por um grupo de professores da escola de Belas Artes da Universidade Federal de Minas Gerais com o intuito de levar a arte à coletividade. Realizado como atividade de extensão, apesar de enfrentar uma forte repressão em função do sistema ditatorial implementado pelos militares no país, consolidou-se com um espaço para o debate e reflexão, englobando questões políticas em âmbito nacional e internacional. Segundo a artista educadora "o grupo de professores dos primeiros festivais, (ainda penso assim) estava buscando e propondo uma linha estrutural do pensamento, enfatizando a

\footnotetext{
160 Destaca-se o descompasso das questões pertinentes ao ensino das artes no Brasil e as transformações nas práticas artísticas do período. Na década de 1960, com a ditadura militar, foram abortados os frutos desta trajetória brasileira relacionada ao ensino da arte. No ensino público, a arte foi reduzida ao desenho geométrico, restando apenas algumas experiências no campo das escolas particulares e nas especializadas em arte. A Reforma Educacional de 1971 colocou em pauta o ensino polivalente da arte e articulou o processo de formação de professores sob esta perspectiva, condensado em cursos de licenciatura de 2 anos de duração. Ao longo dos anos 1970, alguns programas foram articulados para capacitar os profissionais das secretarias estaduais, e até mesmo para integrar comunidade e escola por meio do ensino da arte. A reflexão crítica sobre o ensino da arte ficou estancada ao longo de todo este período, cerceada pela ausência da liberdade de pensamento e expressão política. Apenas nos anos 1980, quando os movimentos da sociedade civil em prol da democratização atingiram força e expressividade, é que foram retomadas as questões pertinentes ao ensino da arte. Alguns avanços profundamente significativos decorreram deste período até o início dos anos 1990. Dentre esses merecem destaque o fortalecimento das associações de arte-educadores, a criação do Programa de PósGraduação na Universidade de São Paulo, além da frutificação de pesquisas acadêmicas. BARBOSA, Ana Mae (Org.). História da Arte-Educação. São Paulo: Editora Max Limonad, 1984.
} 
linha do desenho. Essa linha pode ir para o espaço [...] Não linear no sentido da continuidade, mas no sentido da linha no espaço e no tempo" ${ }^{161}$.

A ruptura com os valores e linguagens tradicionais e 0 abandono dos suportes artísticos convencionais também comportavam um sentido revolucionário e desafiador. A pintura de cavalete se descolava de seu plano de importância na poética de integrantes dessa geração. Havia uma crescente apropriação de objetos e símbolos do cotidiano e uma maior atração por materiais menos nobres, precários e de uso corrente. Em lugar da escultura tradicional, os chamados "objetos" e "caixas", realizados com materiais pouco ortodoxos invadiam os salões e exposições alternativas do período, revelando a rejeição pelos artistas das atitudes exclusivamente formalistas e das posições esteticistas em favor de vínculos imediatos com a existência ao redor ${ }^{162}$.

No contexto internacional, o diálogo se dava com artistas como Joseph Beuys, Luís Camnitzer, Tim Rollins e Jef Geys. Particularmente Beuys, um dos artistas alemães mais importantes da segunda metade do século $X X$, que considerava que por meio da arte, como uma ferramenta no processo de formação do homem, poderiam ser ampliadas as capacidades humanas para resolução de problemas sociais. O conceito ampliado de arte de Beuys, já citado, como Escultura Social, que era endereçado ao estímulo à liberdade e criatividade dos sujeitos, se estendeu para as esferas ecológicas e políticas, por meio do uso das mídias.

O uso incomum dos materiais, compreendidos como elementos "simbólicos de energias presentes no contexto da sociedade e do trabalho artístico"163, abriu espaço para as se pudesse pensar nas práticas estéticas em seus inúmeros usos e possibilidades semânticas. Em tempo, repercutiam as ações do Grupo Fluxos, do qual Beuys fez parte, e sua oposição ao objeto artístico tradicional como mercadoria. Com origens complexas no Futurismo italiano, no Dada, especialmente em Marcel Duchamp, no surrealismo e no construtivismo soviético, na filosofia Zen, o Fluxus configurou-se como uma

161 FRANGE, Lucimar Bello. Entrevista concedida a Carlos Weiner M. de Souza, São Paulo, 07 de junho de 2014.

162 ZANINI. Walter. História geral da arte no Brasil. São Paulo: Instituto Moreira Sales, Fundação Djalma Guimarães, 1983. p.73.

${ }^{163}$ ROSENTHAL, 2002. 
comunidade informal de músicos, artistas plásticos e poetas radicalmente contrários ao status quo da arte.

No contexto brasileiro, artistas como Cildo Meireles, Hélio Oiticica e Lygia Clark, cada qual a sua maneira, criavam estratégias simbólicas e metafóricas para penetrar o cerco à liberdade de expressão imposta pelo regime militar que se estendeu até a década de 1980. As experiências propostas por Lygia Clark e Hélio Oiticica são paradigmáticas para compreensão do trabalho de Lucimar Bello Frange. Tanto de sua poética, quanto de seu trabalho formativo.

Se em Lygia Clark a experiência passa pela relação da obra e do artista com o outro, pelo "imanente realizado pelo participante" ${ }^{164}$, em Oiticica o corpo atua como motor, a descoberta de um estado de invenção. Uma arte ambiental que retira o público da condição de espectador e o coloca como participante da ação criadora. A experimentação e a participação designam uma "outra ordem do simbólico (o comportamento), [...] uma imagem da arte como atividade em que não se distinguem os modos de efetivar programas estéticos e exigências ético políticas"165.

As práticas artísticas desse período, tanto do ponto de vista estético, quanto de ordem política e cultural, são marcantes no trabalho que a artista educadora desenvolveria nos anos posteriores. A utilização de materiais precários e muitas vezes efêmeros, carregados de significação cultural; a ideia da obra como ato de fazer a obra, e não apenas como sua materialidade; a participação do outro como um cúmplice na construção do conhecimento por meio da experiência com o ato criativo, são características que se acentuaram na década de $1980^{166}$.

Trabalhos como "Raoni \& Sapaim", "Cerradianas de Minas" e "Instalações em canteiros de obras" são alguns dos exemplos dessa perspectiva adotada pela artista. O primeiro desenvolvido entre 1981 e 1986, com pistola e tinta esmalte sobre tela, cuja temática trazia a homenagem aos modos de vida dos índios brasileiros, aponta o deslocamento do artista comprometido em nome de um outro cultural ou étnico. O segundo, foi realizado entre 1981 e 1995,

\footnotetext{
164 FIGUEIREDO, L., (org.), (1996). Lygia Clark - Hélio Oiticica: Cartas, 1964-74. Rio de Janeiro: UFRJ.

${ }^{165}$ FAVARETTO, Celso. Inconformismo Estético, Inconformismo Social, Hélio Oiticica. In: Fios Soltos: a arte de hélio oiticica. Paulo Braga (org). São Paulo, 2011. Ed. Perspectiva.

166 Disponível em www.lucimarbello.com.br. Acessado em: 22/06/2014.
} 
composto por 50 desenhos com a apropriação de pôsteres-encartes da Revista "Ele \& Ela", ganhador de prêmios em salões nacionais ${ }^{167}$. E o terceiro realizado na cidade de Uberlândia em 1989. Uma intervenção com a parceria dos profissionais-operários da construção civil, que também contava com a participação dos estudantes do curso de Artes Plásticas e do curso de Decoração da Universidade Federal de Uberlândia (figura 22 e 23) ${ }^{168}$. Iniciativas que Ihe possibilitaram exposições no Japão e na Espanha.

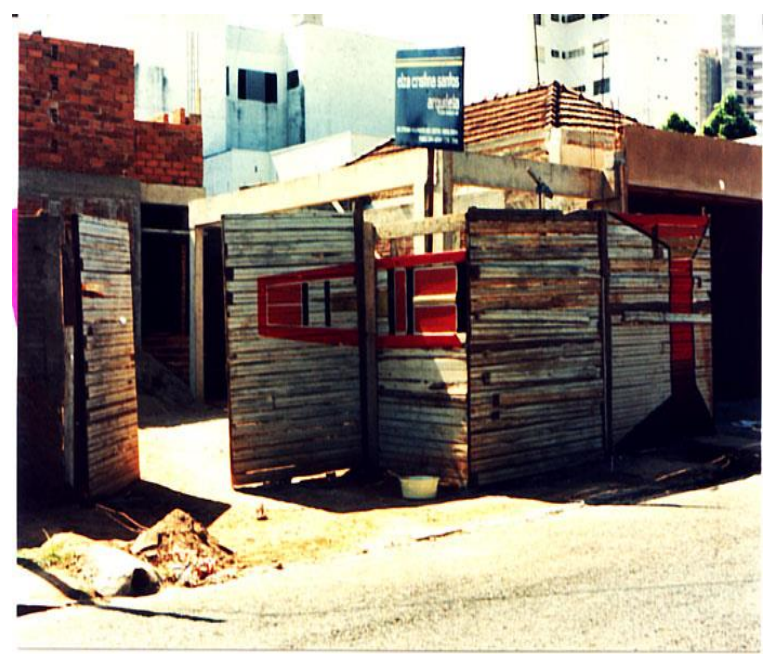

Figura 22: Fotografia: Instalações em canteiro de obras. Lucimar Bello Frange, 1989. Fonte: Acervo da artista.

${ }^{167}$ As imagens eram transferidas por frottage para papéis brancos e, posteriormente trabalhadas com aerógrafo, nanquins e lápis de cores aquarelados e secos. As Cerradianas viajaram pelo país - uma Exposição Itinerante: Recife, Galeria Aluízio Magalhães; Salvador, Capela do Solar do Unhão; Belo Horizonte, Galeria do IAB; Curitiba, Museu Metropolitano de Artes; Porto Alegre, MARGS. Ganhei vários prêmios em Salões Nacionais. Alguns desenhos foram expostos no Japão, em Tóquio, Atami e Quioto; na Espanha, em Barcelona. Vale destacar, que este trabalho não pode ser exibido na cidade de Curitiba-PR, na qual as autoridades rejeitaram as referências ao corpo, rotulando-as como indevidas. Fonte: Frange, Lucimar Bello. Múltiplas Lucimares de lugar algum. A trajetória entre Arte e cidades e subjetivações

168 FRANGE, Lucimar Bello. SamPer, cartografias cidadianas; dos Alpes ao Ilhade Capri Disponível em http://anpap.org.br/anais/2007/2007/artigos/146.pdf Acessado em 25/06/20. Pp $1439-1448$ 


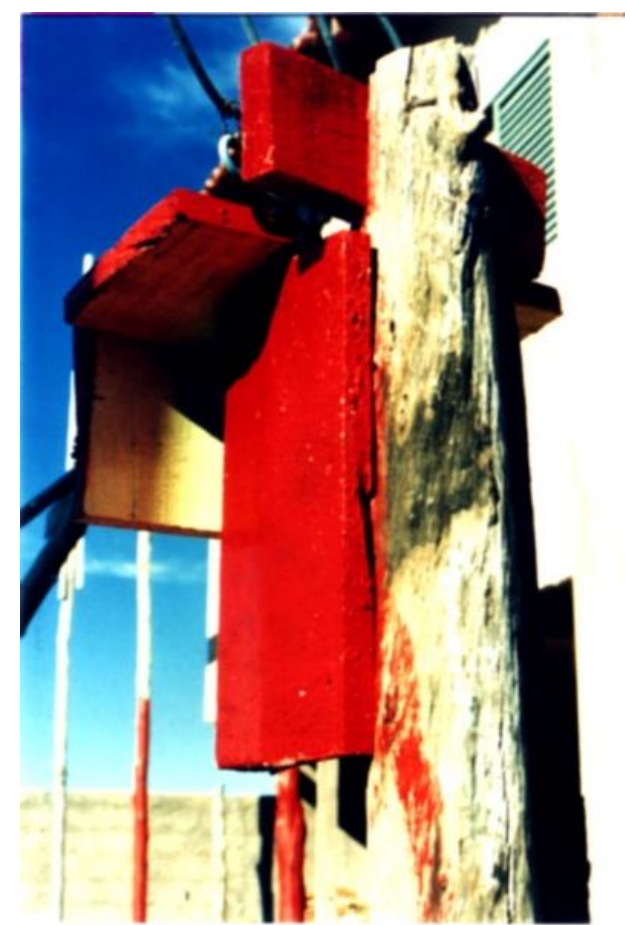

Figura 23: Fotografia : Instalações em canteiro de obras. Lucimar Bello Frange, 1989. Fonte: acervo da artista.

O olhar de Frange, que seleciona coisas do mundo e as transforma em matéria prima para criação, possibilita um deslocamento temporal para enfatizar o diálogo iconográfico em seu trabalho. As imagens da instalação "Canteiros de obras" reportam um dos trabalhos da artista que é, segundo suas próprias palavras,

[...] pega pela proximidade espaço temporal com um edifício em construção [...] "pega em meio a proliferação de habitações prêt-à-porter que invadem uma grande cidade. Sentia a premência de fazer alguma coisa com aqui [..] Lucimar foi convocada, num movimento ininterrupto de criação e destruição do mundo gritava em sua janela"169.

Frange se refere a uma trilogia, ao trabalho "Cidades +" 'Vasas cidades" e a"SamPer, cartografias cidadianas; dos Alpes ao llha de Capri". Um vídeo arte, um conjunto de looping, de fotos-desenhos realizados durante dois anos e meio. De um lado, um edifício em construção, de outro, o olhar atento de quem tem nas transformações e tensões do espaço urbano, um parceiro de conversa. Apropriando-se de uma referência ao título da canção de Caetano Veloso Olímpia. 2006, p.5. Disponível em www.lucimarbello.com.br . Acessado: 23/12/2014. 
"sampa" e da primeira sílaba do bairro onde residia, Perdizes, a artista expõe a temporalidade em suas vísceras. Explora os empilhamentos, dos excessos e proliferações de uma dinâmica daquilo que rapidamente se modifica. No texto que escreveu sobre este trabalho, trouxe Mario de Andrade para o diálogo. É constante em sua poética um diálogo profícuo com a literatura. Nesse sentido, traz a observação/ imagem do poeta e escritor em sua comoção com a cidade, em sua percepção de que a cidade é capaz de sintetizar todas classes sociais, de incorporar "pela grande boca de mil dentes" os seus antigos senhores. $O$ diálogo que sustenta o processo criativo se estende às "janelas indiscretas" de Alfred Hichcock, aos olhares inconvenientes dos espaços Big Brother's. São passagens pelas diversas significações daqueles que olham e se deixam olhar, da vulgaridade à poesia. São movimentos incontroláveis da vida que passa por todos e mostra as indiferenças de algo que se constrói, mas nada tem a dizer ao outro. Uma caixa de morar. Frange faz da câmera um lápis, um "falso grafite torna-se o indício da passagem da luz e dos tempos, relação entre uma imagem indicial (a construção em-se fazendo), e nossos olhares, Alpes e Capris, marcas de presenças por suas ausências, presenças minhas marcas, rastros

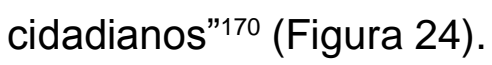

${ }^{170}$ FRANGE, Lucimar, 2007, op, et seq., p. 142. 

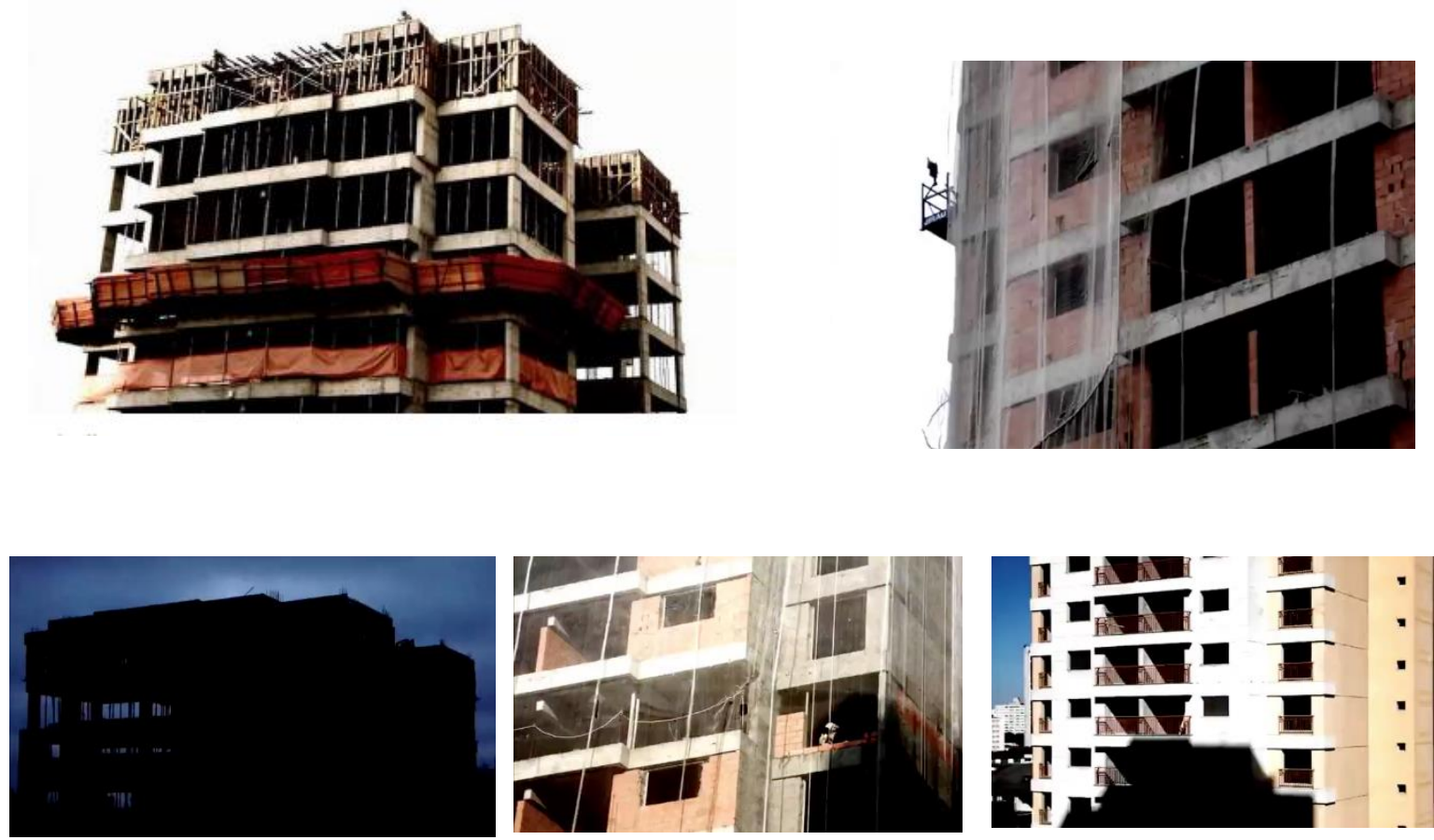

Figura 24. Fotogramas. Vídeo "Dos Alpes ao Ilhas do Capri". Lucimar Bello Frange. 20062010. Fonte: Acervo da artista.

Frange trabalha revisitando seus percursos, parte da ideia de um totus em continuum que promove as dúvidas e inquietações que adensam seus caminhos pesquisantes, em poéticas visuais e processos de criação.

Entre os anos de 1991 e 1992, morou em Liverpool, Inglaterra, onde passou a frequentar um atelier coletivo na Tate Gallery e desenvolveu uma série de trabalhos, que segundo a própria artista, fizeram com que passasse a investigar suas "pegadas interculturais"171. Nesse período, começou a explorar as relações estéticas e conceituais pela fusão de diferentes materiais. De volta ao Brasil focou-se nas relações estéticas visuais e conceituais de câmaras de ar usadas, explorando as densidades da cor negra e aprofundando seus experimentos com as propriedades físicas dos materiais como borracha, couro e talco (Figuras 25 a 29).

${ }^{171}$ FRANGE, Lucimar Bello, 2008 p.01. 

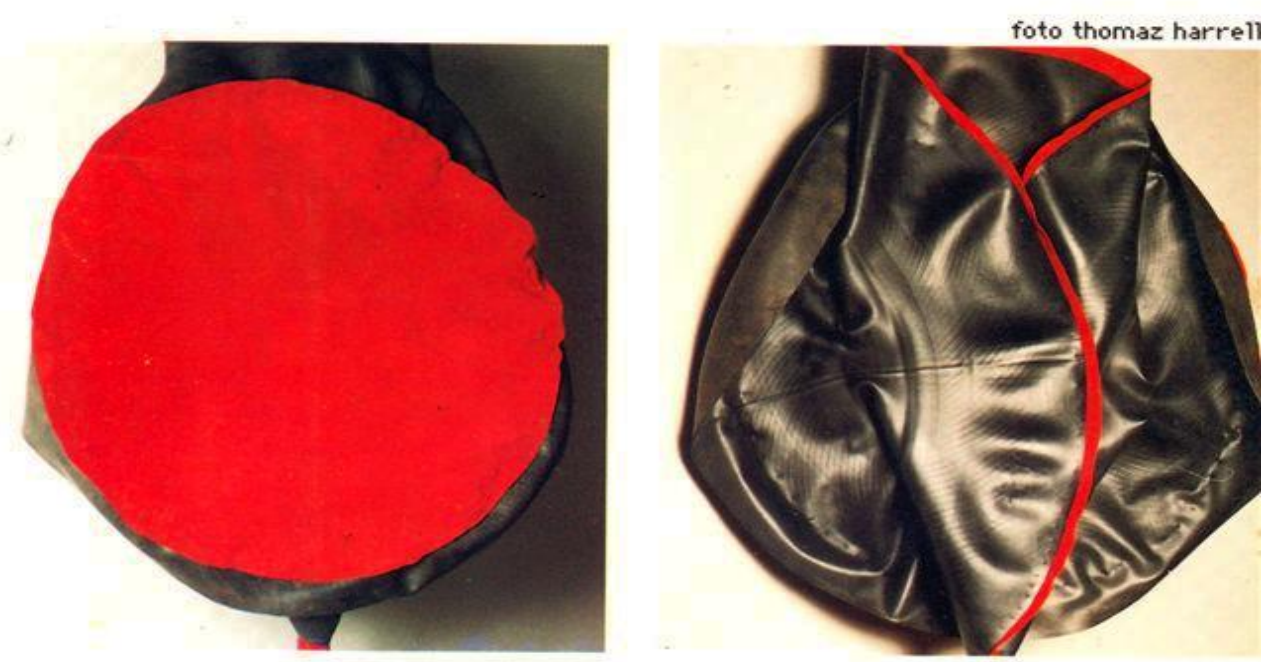

\section{lucimar bello lucimar bello lucimar bello desenhos escultóricos desenhos escultóricos galeriaparangolé espaço cultural 508 sul brasília 05 a 17 outubro 1994}

Figura 25. Fotografia. Autor: Thomaz Harrell. Exposição de Lucimar Bello em Brasília-DF, 1994. Fonte: acervo da artista.
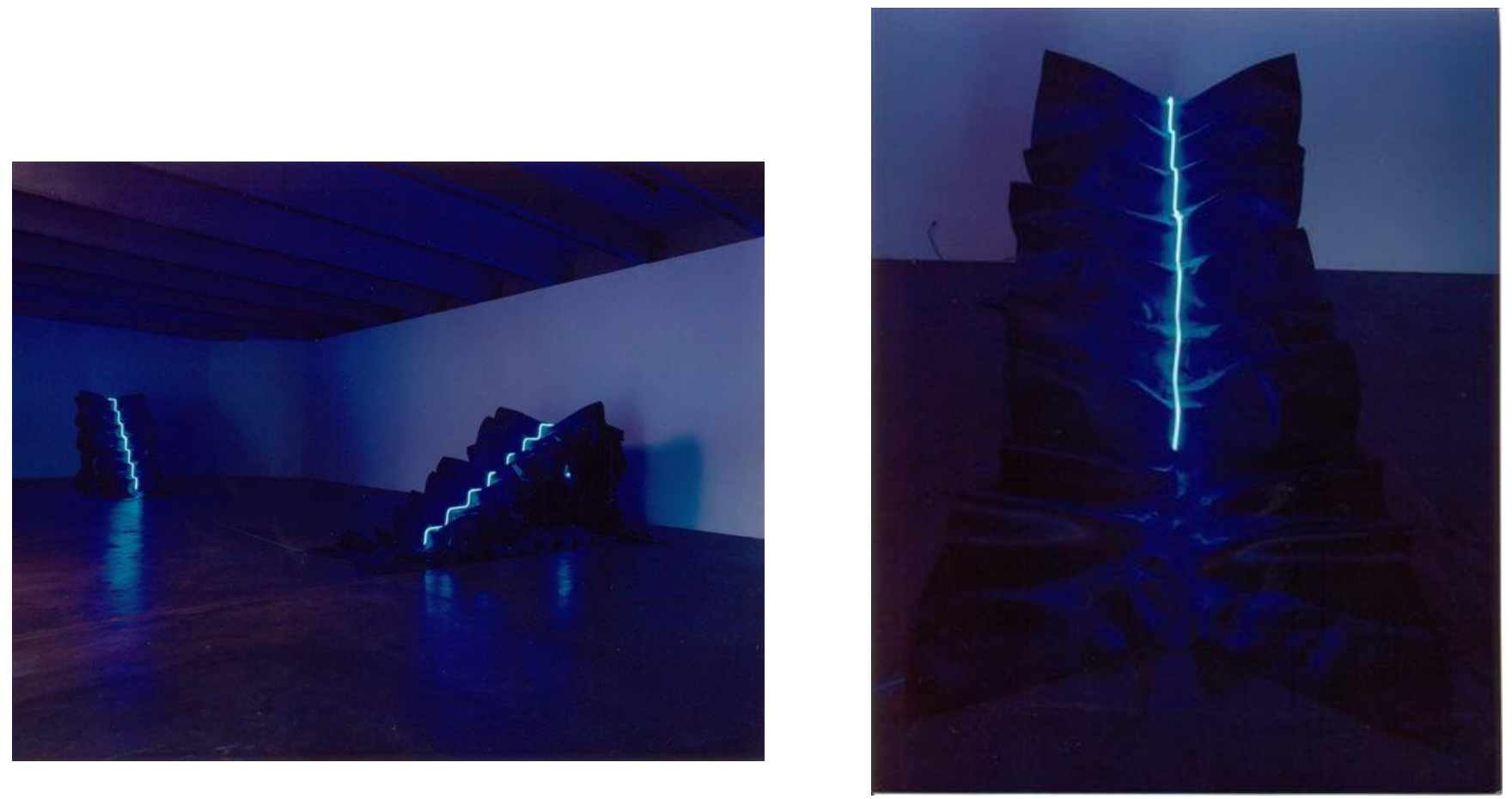

Figura 26. Fotografia. Autor: Thomaz Harrell. Exposição de Lucimar Bello em Brasília-DF, 1994.Fonte: acervo da artista. 


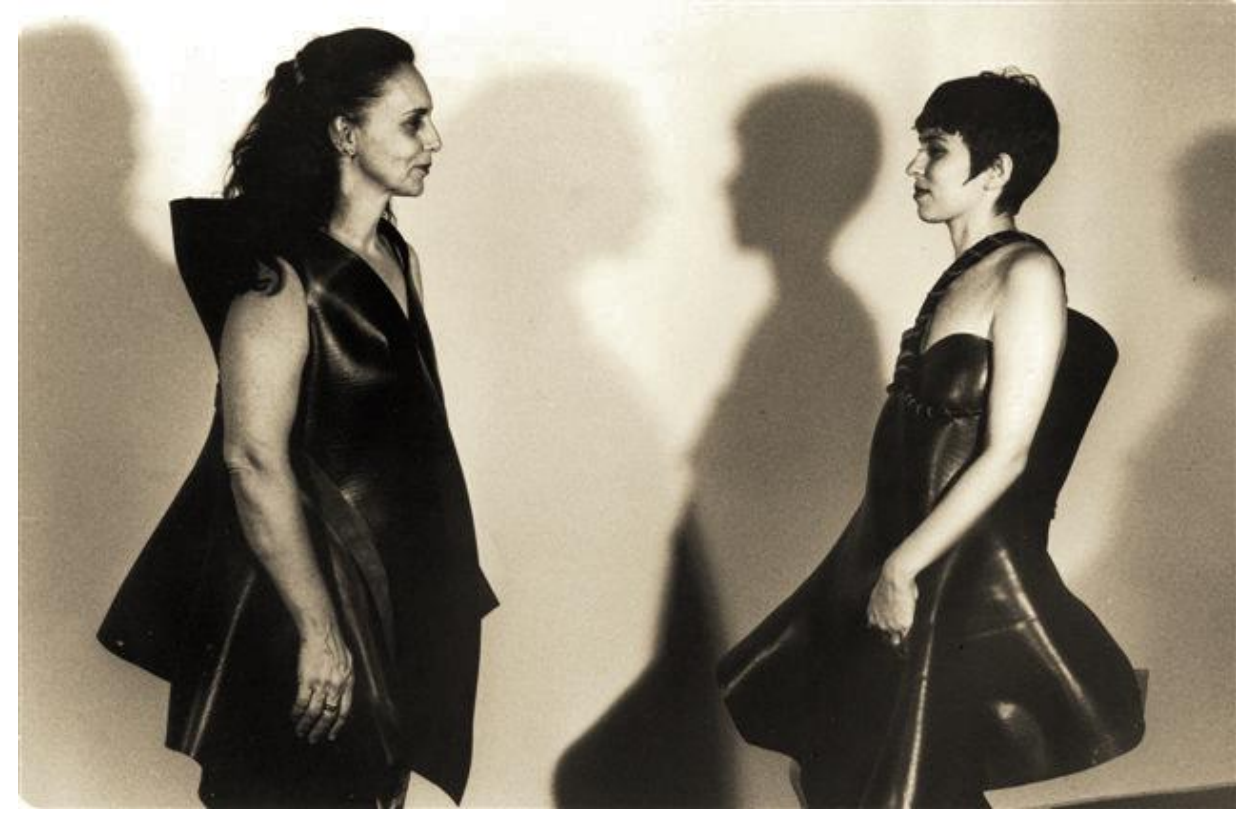

Figura 27. Fotografia. Autor: Thomaz Harrell. Exposição de Lucimar Bello em Brasília-DF. Desenhos de vestir 1994.

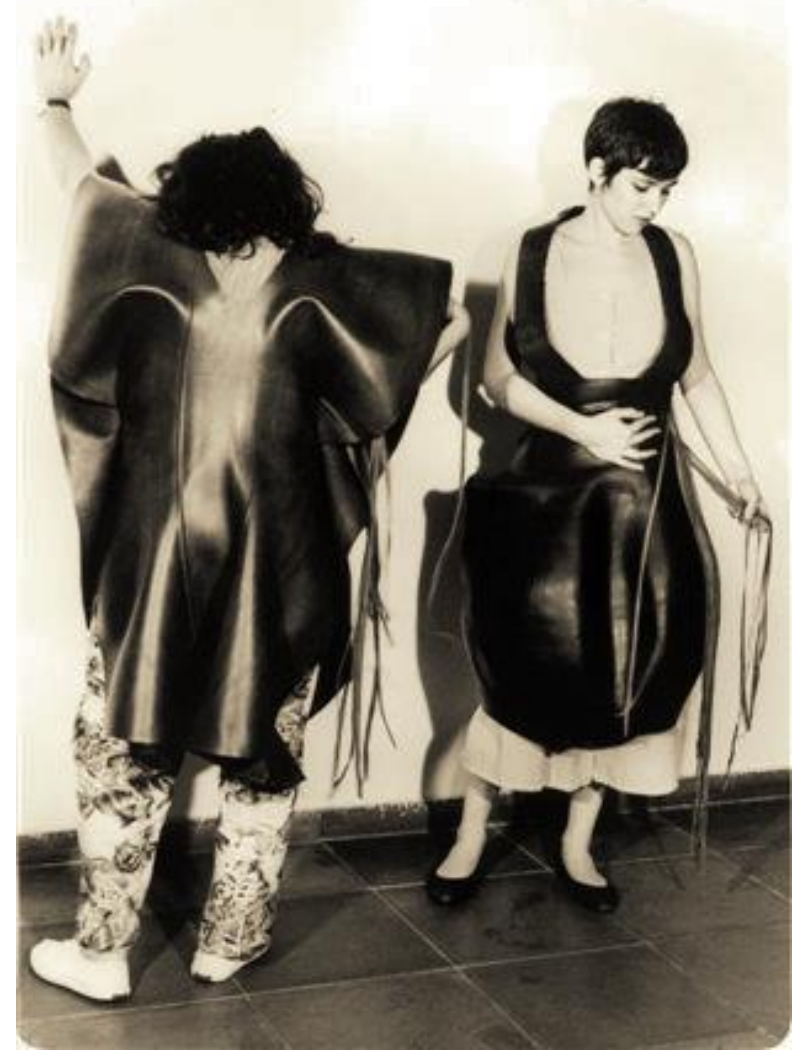

Figura 28. Fotografia. Autor: Thomaz Harrell. Exposição de Lucimar Bello em Brasília-DF. Desenhos de vestir 1994.

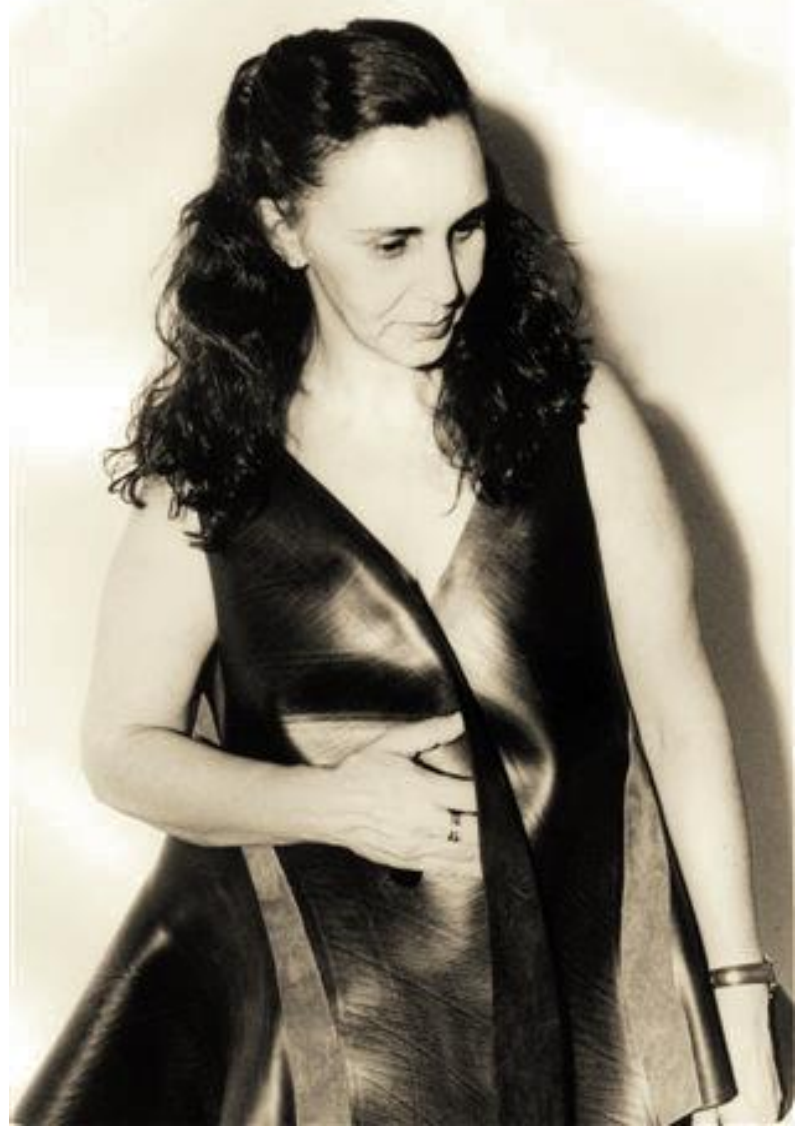

Figura 29. Fotografia. Autor: Thomaz Harrell. Exposição de Lucimar Bello em Brasília-DF. Desenhos de vestir 1994. 
Nessa orientação e atravessamentos nasceram o projeto "Dias Desenhantes", na cidade de Uberlândia, Minas Gerais, no ano de 1993. Seus desenhamentos se estenderam para São João Del Rei, na sexta edição do Inverno Cultural, FUNREI, com uma proposta que envolvia o patrimônio material e imaterial da cidade, como também, para Belém-PA e Campinas-SP. Nasceu também, "Uma Semana Desenhante" "Oficina de Desenho Urbano-desenhando e construindo a Cidade no Cerrado", projeto ambicioso e coordenado em parceria com professor e geógrafo Falcão Vasconcelos e uma equipe composta por alunos, funcionários, professores da Universidade Federal de Uberlândia e membros de 10 Secretarias Municipais, da Prefeitura Municipal da cidade de Uberlândia. Nesse projeto foram realizados 3.800 desenhos em 26 praças e em 4 distritos da cidade. Um trabalho que envolveu 348 oficineiros-colaboradores de diversificadas profissões (Figuras 30 a 34)

Suas experimentações culminaram com a aprovação de um projeto de pesquisa em Arte da Fundação VITAE (1994), intitulado de "Cidades utópicas, desenhos contemporâneos". Em todos esses projetos o campo estético era ativado em sua dimensão social, como expressões de grupos que canalizam suas energias por meio da percepção, interferindo na paisagem experimentada. O compartilhamento e a multiplicação de um desejo de configurar formas que buscam para si e para os outros. São territórios onde objeto e participantes, corpo-a-corpo desenham e desenham-se em desdobramentos de territórios que se entrecruzam.

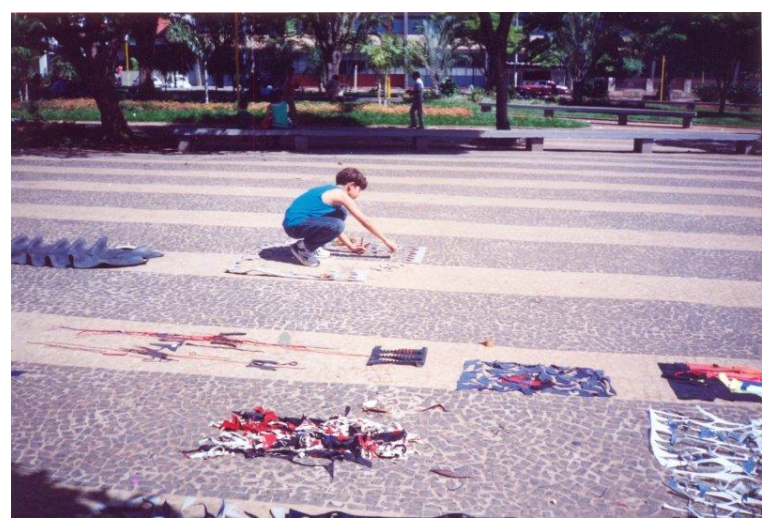

Figura 30. Fotografia. Dias desenhantes. Belém - PA. Fonte: acervo da artista

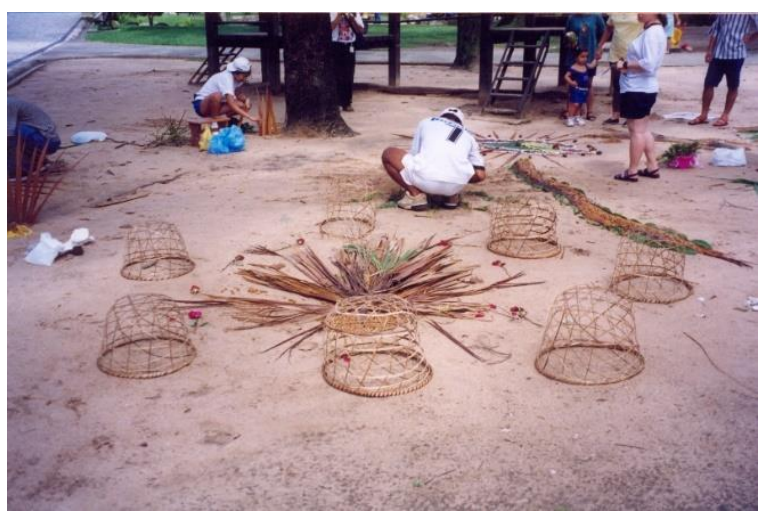

Figura 31. Fotografia. Dias desenhantes. Uberlândia - MG 1. Fonte: acervo da artista 


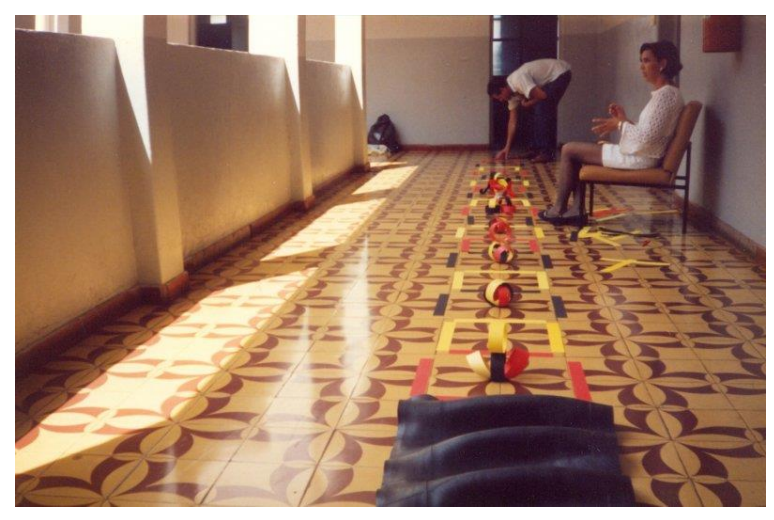

Figura 32. Fotografia. Dias desenhantes. Uberlândia - MG 2. Fonte: acervo da artista

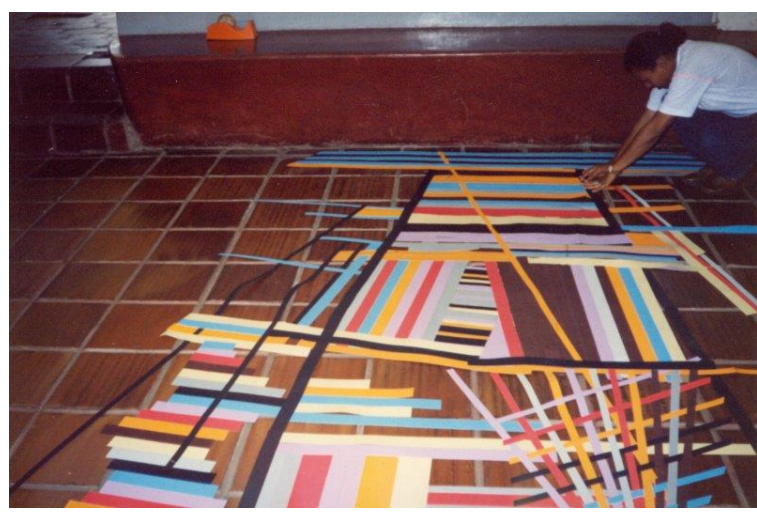

Figura 33. Fotografia. Dias desenhantes. Uberlândia - MG 3. Fonte: acervo da artista

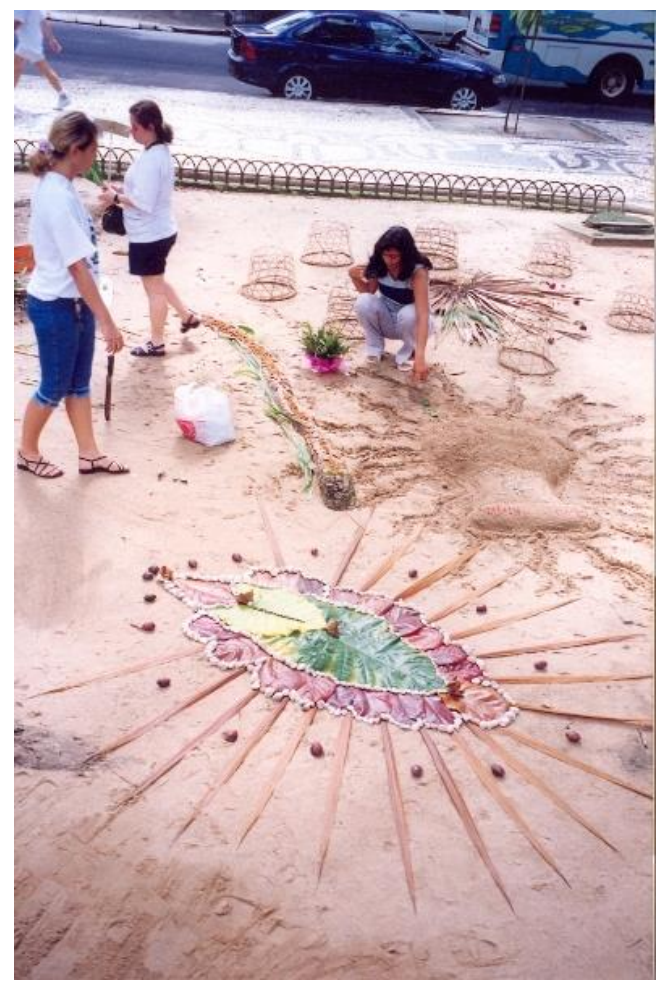

Figura 34. Fotografia. Dias desenhantes. Belém - PA 2. Fonte: acervo da artista

Destaca-se que, na década de 1990, as práticas artísticas situadas em contextos, que dão ênfase às relações sociais, se proliferaram em grande parte do mundo. Novos alinhamentos em que surgiram novos atores sociais e, segundo Cesar ${ }^{172}$, contexto em que o artista se tornou uma espécie de mediador

172 CESAR, Marisa Flórido Cesar. $\mathbf{O}$ artista e a cidade. Transformações na prática artística: entre a rua e $\mathbf{o}$ ateliê. Curso de História da Arte oferecido pela Pinacoteca do Estado de São Paulo. 2011. Disponível em: https://www.youtube.com/watch?v=f1Sp EwnSD5k . Acessado 25/04/2014. 
social, o etnógrafo de micro estratégias de territorialização, um agenciador, que provoca situações rápidas e perturbadoras, pequenos ruídos na entropia urbana, estabelece estratégias de intervenção no cotidiano como forma de criar instabilidades nas práticas e nos hábitos de grupos sociais e culturais distintos ${ }^{173}$.

As reverberações e entrelaçamentos das práticas artísticas com os modos de vida social se refletiam de maneiras diversas e nem sempre consensuais. Esses deslocamentos da arte, por vezes radicais e contraditórios, são um marco nas mudanças perceptuais e na construção de novos contextos nos quais a arte insere outras possibilidades na reconfiguração da experiência. O que ampliou não só os debates sobre o tema, mas também tornou a arte indissociável dos campos da ética, da política e da cultura.

No início do século XX, ainda nos anos 1930, John Dewey havia aproximado radicalmente a noção de experiência estética da vida ordinária, 0 que o coloca como um precursor desse movimento. Principalmente, na medida em que reportava a uma ideia de experiência, cuja singularidade deveria estar na qualidade da ruptura do fluxo contínuo da vida corrente, no exercício da alteridade, na crítica aos espaços sacralizados que apartam a arte da vida humana. Uma abordagem incorporada ao trabalho de Frange e, cujo delineamento está na experiência como uma "atividade que ocorre sempre em

\footnotetext{
173 Salienta-se que a sistematização da Abordagem triangular representa um marco no campo teórico-prático do ensino da arte neste contexto). Sistematizada a partir de 1983 no Festival de Inverno de Campos de Jordão, São Paulo, foi intensamente pesquisada entre 1987 e 1993 no Museu de Arte Contemporânea da Universidade de São Paulo e na Secretaria Municipal de Educação sob o comando de Paulo Freire e Mário Cortela. (RIZZI, 2008). A abordagem de Ana Mae Barbosa se estruturou a partir das condições estéticas e culturais da pós-modernidade. Em diálogo com as iniciativas que vinham se desenvolvendo na Inglaterra, com o Critical Studies, e nos Estados Unidos, com o Disciplined Based Art Education (DBAE), fundamentado nas disciplinas Estética, História, Crítica e no fazer artístico e com as Escuelas al Aire Libre no México. Barbosa introduziu no cenário do ensino da arte no Brasil uma perspectiva diferenciada, capaz de refletir as especificidades e multiplicidades do universo cultural brasileiro. (RIZZI, 2008). A orientação que promoveu a adoção da experiência da imagem, sua decodificação e interpretações em sala de aula, aliada à já conquistada expressividade, herança das proposições modernistas, passou a postular que "construção do conhecimento em arte acontece quando há o cruzamento entre experimentação, codificação e informação" (RIZZI, 2008, p. 337). Segundo Rizzi, esta abordagem propõe que a composição do programa de ensino seja elaborada para permitir relações com os planos não apenas da percepção, mas, político, histórico, tecnológico e identitário. O que permite que o conteúdo das experiências se consolidem no mundo vivido da cultura, e que dele se extraia seu valor. (p.337). Os estudos e pesquisas de Barbosa no final dos anos 1980, que definiram sua abordagem para o ensino e a aprendizagem da arte, apontaram para reflexões ainda pouco exploradas no contexto brasileiro. Principalmente, no que se refere às interações entre os aspectos que emergem da diversidade cultural brasileira e compreensão dos modos de produção da imagem nas poéticas contemporâneas nas artes visuais e seu papel na experiência estética, examinando sua relação e seus efeitos sobre os processos mediados pelo ensino da arte a partir da prática de artistas educadores.
} 
Um espaço relacional, como uma possibilidade de diálogo, como uma troca ativa e alerta do mundo [...], uma interpretação completa entre o eu e o mundo dos objetos e acontecimentos" 174 .

É nesse fluxo que surgiram os trabalhos de Frange realizados entre os anos de 1998 e 2001, reforçando as inquietudes dos anos de 1980, principalmente, no sentido de buscar uma constante integração de sua poética com histórias pessoais e coletivas por meio da expressão plástica, da experiência com a imagem, como um projeto transdisciplinar. Entendendo essa denominação, como afirma Frange, como a "quebra das barreiras entre as áreas de conhecimento e um trabalho de com-junto entre elas"175.

Mesmo em suas exposições individuais a experiência da imagem assume, em essência, a alteridade que se expressa desde a escolha e guarda da matéria, aos processos de dar forma e nas maneiras como essas imagens são endereçadas à experiência com o público. As instalações "Brancos sobre Brancos" realizadas na galeria de arte do Museu Universitário de Arte, da Universidade Federal de Uberlândia, no Museu da Amazônia - UNAMA, em Belém e na Escolinha de Arte do Recife, entre os anos de 1998 e 2001, contava com 180 livros usados (livros próprios, da família e de sebos), que foram amarrados em barbantes, pintados de branco e recobertos de películas transparentes incolor (Figuras 35 a 37). Objetos que o público tinha liberdade de levar. Essa experiência fez parte do período em que Frange trabalhava em seu primeiro pós-doutoramento, cuja resultado foi a publicação "Noemia Varela e a arte", que derivou um vídeo documentário sobre a reconhecida educadora pernambucana, uma das maiores referências na história do ensino da arte no Brasil.

174 DEWEY. John., 2010. p.83.

175 FRANGE, Lucimar Bello. VASCONCELOS, Luiz Gonzaga Falcão (Org). Oficina de desenho urbano: desenhando e construindo a cidade no cerrado. 2.ed. Uberlândia: Universidade Federal de Uberlândia / PROEX, 2004 


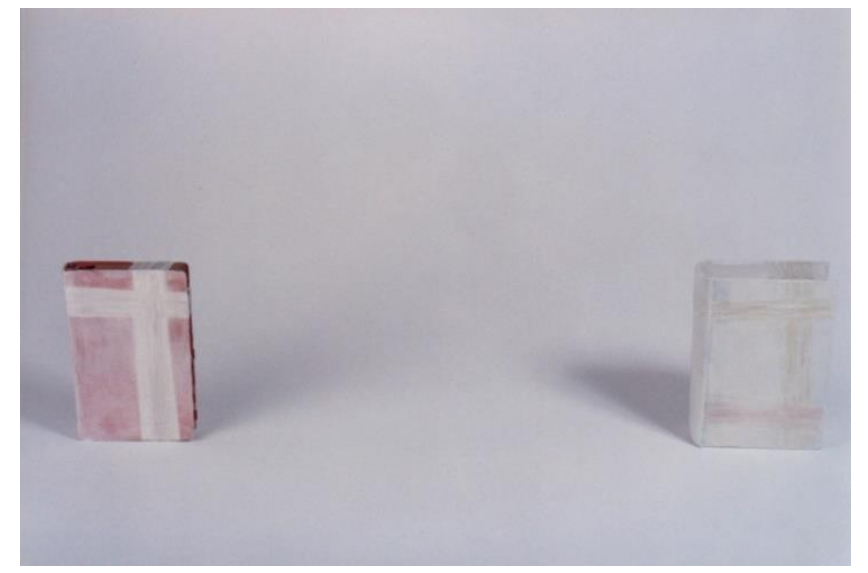

Figura 35. Fotografia. Instalação Branco sobre Branco. 1998-2001. Fonte: acervo da artista

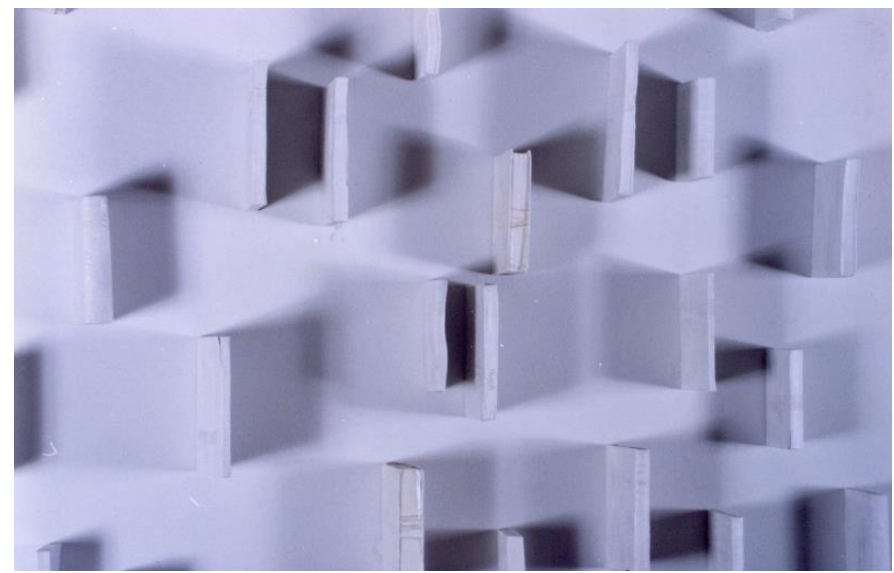

Figura 36. Fotografia. Instalação Branco sobre Branco. 1998-2001. Fonte: acervo da artista

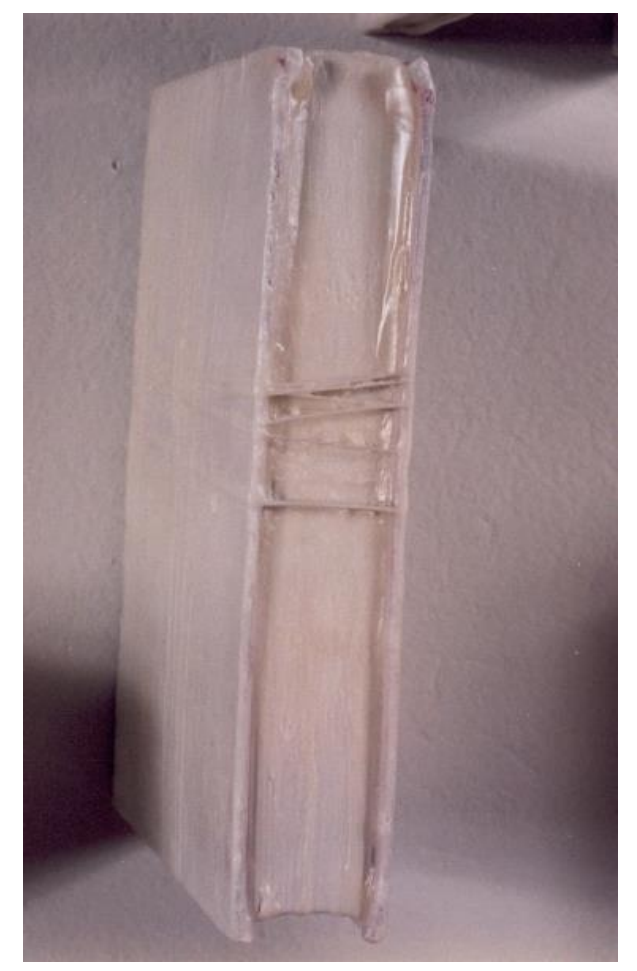

Figura 37. Fotografia. Instalação Branco sobre Branco. 1998-2001. Fonte: acervo da artista

Nos trabalhos "manuscriptus" realizados entre os anos de 2002 e 2006, a artista resgata registros de aulas de um curso de especialização em História Moderna e Contemporânea guardados, entre os anos de 1984 e 2004. As anotações só não tiveram o lixo como destino por um deslocamento do olhar que 
mirou. Arqueologicamente, movimentos do passado, são utilizados como suporte para monotipias e convertem-se em "corpos-escrituras" e "corposimpressos". Expressam a articulação e materialização da memória do passado, como um fenômeno estético (Figura 38). Como o in.temporal do que somos, e não o que virtualmente seríamos capazes de ser. Ao mesmo tempo, uma "[...] explored consciousness towards reality [...] the reality of aesthetic 'conscience"176.

São dois movimentos construtivos e constitutivos da memória que devem ser pensados no âmbito dos entrelaçamentos de sua poética e de sua ação no campo formativo. O primeiro ativado pela resposta dos sentidos às coisas enterradas no fundo da vida, um movimento que se faz com a memória na justaposição do agora do tempo ao ontem do tempo. O segundo definido pela materialidade compartilhada e "compartrilhada" de ações "com.juntas" compondo um narrativa que se sustenta, desenha e alinhava a própria trajetória como artista e educadora.
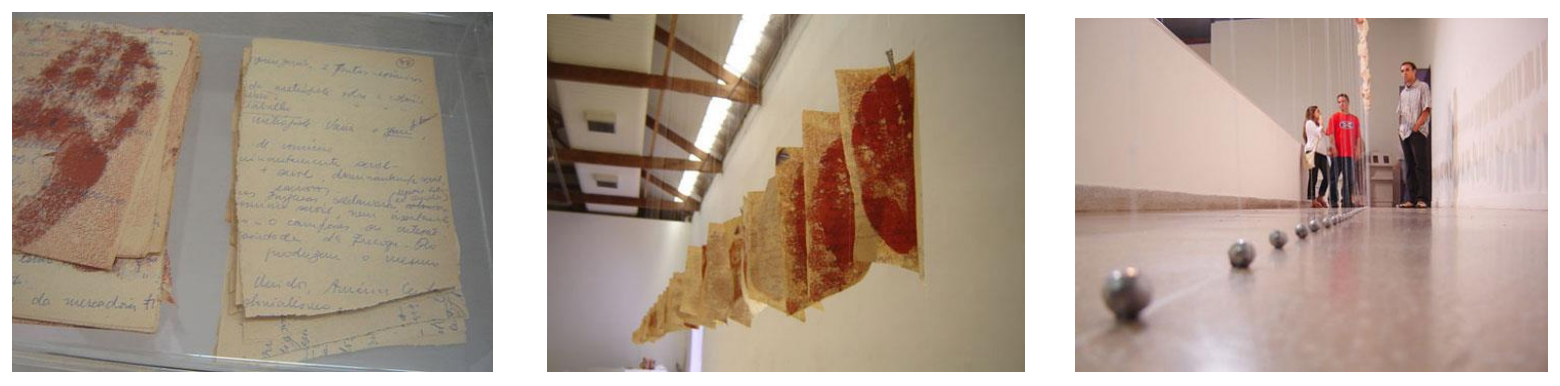

Figura 38. Fotografia. Instalação manuscriptus, 2006. 240 monotipias, impressas sobre papeis presas por presilhas de metal ligadas ao teto por fios de nylon e presas ao chão por chumbadas. Universitário de Uberlândia (UFU). Fonte: acervo da artista.

Frange vem realizando pesquisas junto a comunidades a muitos anos. A ativação de sua poética das mínimas coisas, daquilo que é frágil e invisível pela anti-experiência familiar do cotidiano, vem sendo desdobrada em experiências por todo país. Nessas fabrica.ções mantém, de maneira ainda mais refinada, as questões refletidas e acionadas em suas pesquisa de doutoramento, no atelier de desenho comunitário desde o ano de 1993.

${ }^{176}$ FRANGE.Lucimar Bello. Critical Studies: Art Education: a Vision and a Brazilian Interpretation. In: Art e Design Education. 1993,p.377 
Suas práticas estéticas problematizam e permitem que o outro atue como agenciador de campos de experiências, destituindo a hierarquia de saberes antes especializados. São "delicadezas, como dispositivos, na arte contemporânea, de partilha, de doação, de encontros des-interessados e desmercantizados. A pesquisa atual se propõe a questionar, inclusive, a doença da identidade que nos fecha em nós mesmos" 177.

$O$ ato de desenhar, que para Frange são imagens, ideias, indagações, deslocamentos, análises e meios pelos quais os sujeitos inventam o mundo, está intimamente relacionado ao processo formativo em inúmeras dimensões. Entre os anos de 2004 e 2011, a artista marcou no calendário de suas agendas, com sinais, cores, compromissos e viagens as "Coisas a fazer" (Figura 39). São desenhos de seus percursos dos quais derivam uma tabela que mapeia os lugares visitados, 198 ao todo ${ }^{178}$. A partir daí selecionou os que habitou por mais de seis vezes e os transformou em "Desenhos de vezes" (Figura 40), um conjunto de sobreposições de linhas entre o ir e o vir. Depois, de maneira aleatória se apropriou das mesmas linhas e compôs as "Viagens pr'a fazer" (Figura 41)", utilizando óleo de linhaça sobre papel artesanal.
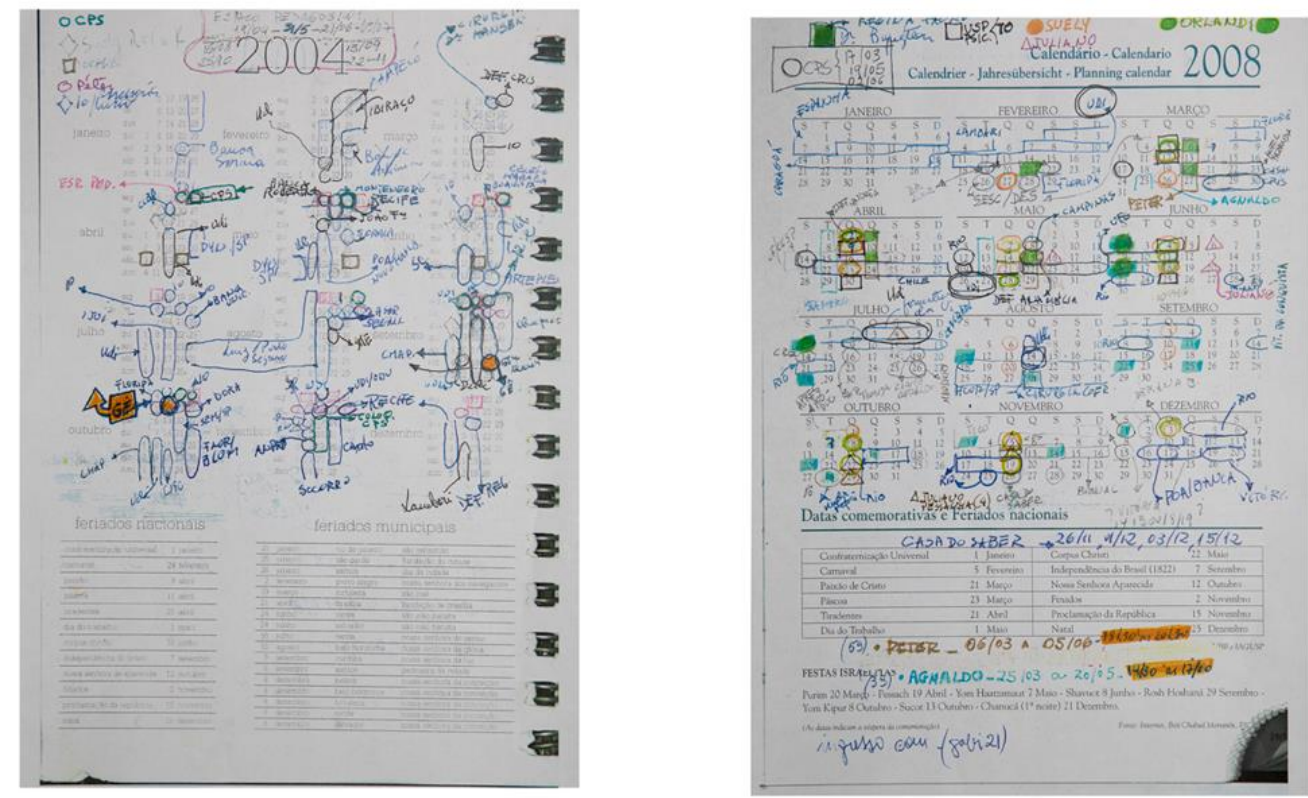

Figura 39. "Coisas a fazer". Lucimar Bello Frange. Fonte: Acervo da artista.

177 FRANGE, Lucimar Bello. Cidades desenhantes, um desnorte. In: Anais XIX ANPAP. Cachoeira: UFBA, 2010 (p.1439-1452). p. 1440.

178 MANATA, Franz. Curador da exposição "Coisas a fazer". Galeria de Arte do Espaço Cultural do Mercado. 

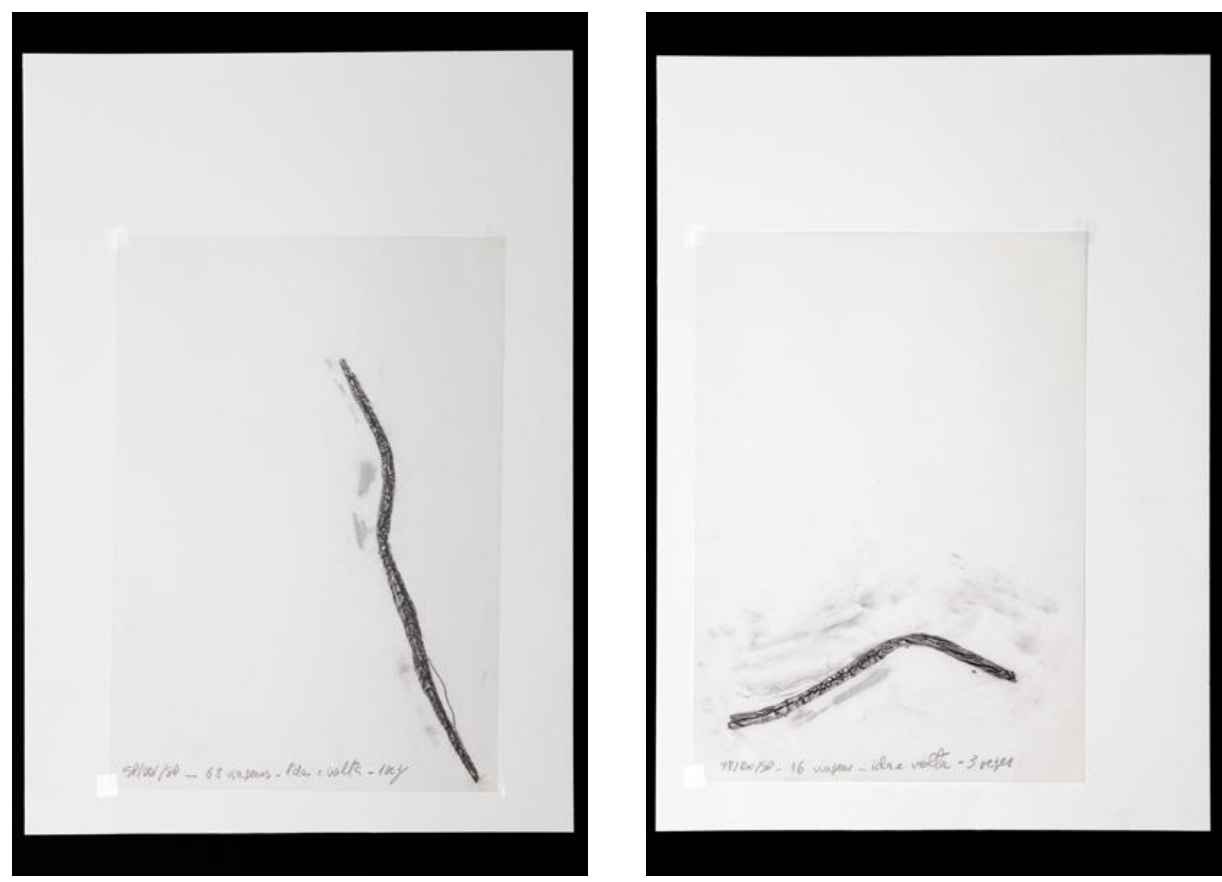

Figura 40. " Desenhos de vezes". Lucimar Bello Frange. Fonte: Acervo da artista.
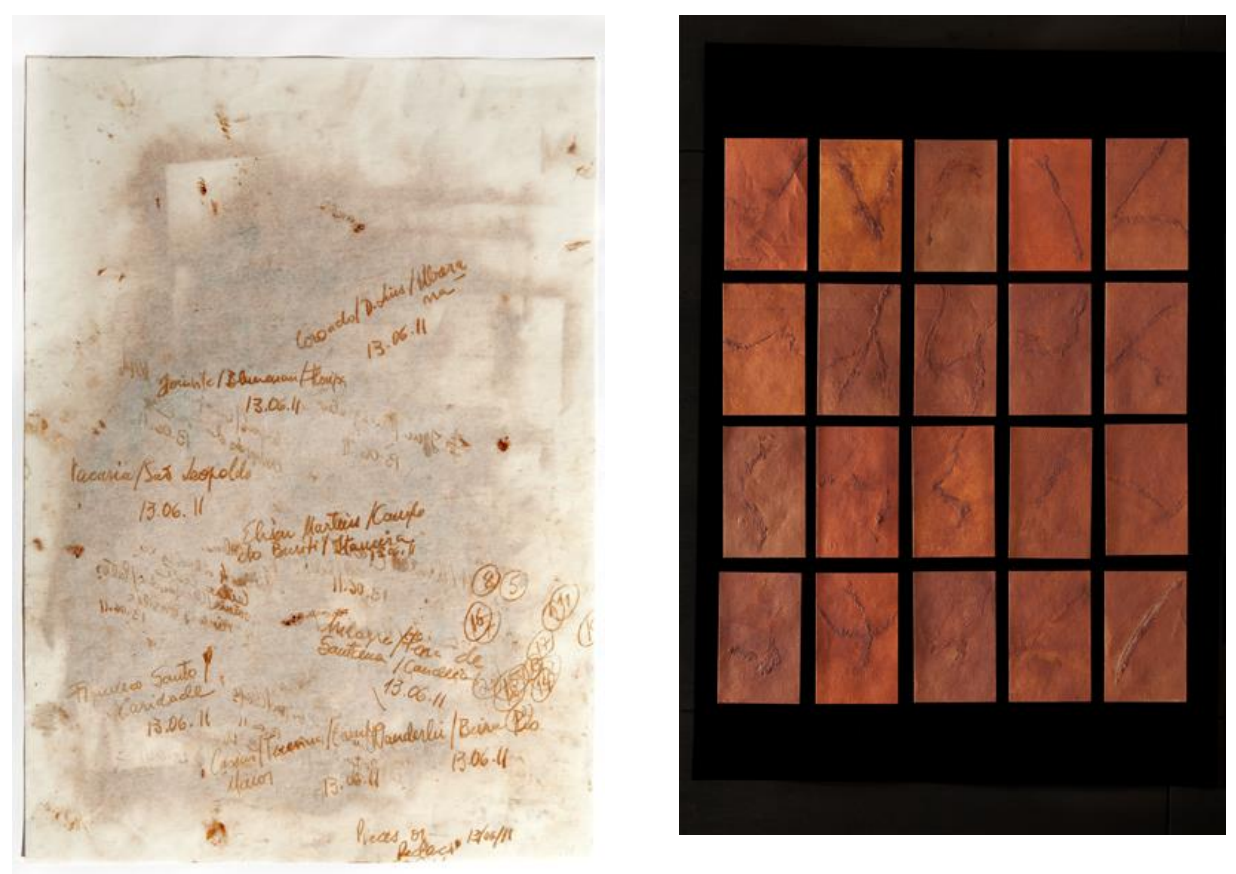

Figura 41. "Viagens pr'a fazer". Lucimar Bello Frange. Fonte: Acervo da artista.

São conexões, movimentos espirais dos processos criativos que articulam a prática artística aos processos de vida. Para que se possa entender esses fluxos é necessário compreender como eles operam em um duplo sentido, de um lado, destitui a ideia de uma natureza a priori, cuja forma legitimaria o senso 
comum do conhecimento, por meio da instituição de um modo de desejar neutro e desinteressado; por outro, no processo educativo, desqualifica a verdade dos valores universais que foram formatados em um plano de objetos ideias. O que torna possível um conhecimento significativo, intimamente ligado à produção das formações sociais. São agenciamentos ativados por meio de dispositivos estéticos que afetam a lógica social, formando linhas de força que apontam, orientam e agenciam sujeitos produzindo subjetividades, "são máquinas de fazer ver e de fazer falar" ${ }^{\prime \prime 79}$, que provocam e ampliam as maneiras de criar a/na vida.

Contemplada com uma residência artística no Instituto SACATAR, na llha de Itaparica (BA), no ano de 2011, a artista definiu como parceiros de criação artistas/escritores (Manoel de Barros, Ítalo Calvino, Artur Barrio, Clarice Lispector, Hélio Oiticica, Ligia Clark, entre outros) com os quais dialoga em suas buscas e abre o corpus de problematizações que estão evidenciados em todo seu percurso. Problematizações, que em essência, levam à compreensão das maneiras como seu processo criativo se torna indissociável dos movimentos que envolvem o processo formativo.

Em junho de 2011, resolveu enviar 65 e-mails com trechos das cartas entre Lygia Clark/Hélio Oiticica - 1964-74 para endereços virtuais que fazem parte da sua agenda. Recebeu 30 respostas, para as quais enviou 65 cartas, via correio. Com elas escreveu um texto em grafite sobre papel de arroz japonês, fazendo combinações entre os e-mails recebidos. Nascia o projeto "Carta ao Mar, em 2 atos: Poemares e Catamentos" (Figura 42).
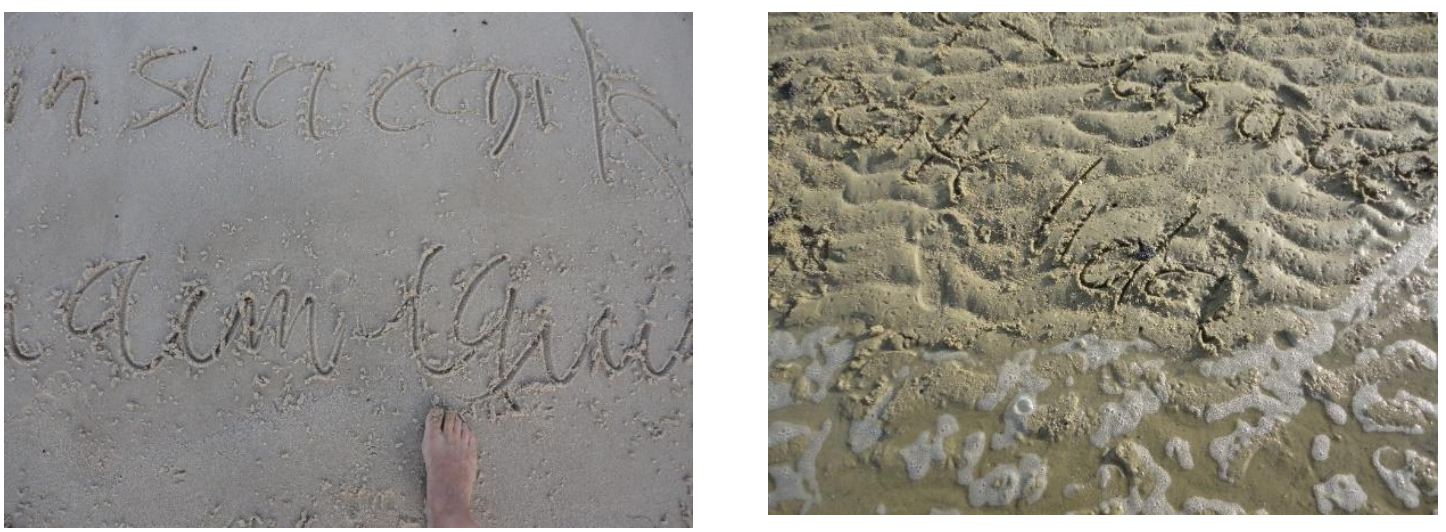

Figuras 42. Cartas ao mar, Poemas e catamentos. Lucimar Bello Frange. Fonte: Acervo da artista.

179 DELEUZE, Gilles. O Mistério de Ariana. Lisboa: Editora Passagens, 1996. P.83. 
Em outra ocasião, a artista xerocou todas as páginas do mesmo livro sobre a correspondência entre Clark/Oiticica, nas quais havia a palavra "carta" e as levou para o Instituto SACATAR - Ilha de Itaparica (BA). A seguir, colocou cada página no chão, para que fosse molhada com suavidade por uma chuva fina. Depois de passar por um estúdio e serem decalcadas com papel toalha de cozinha, surgiam as Cartas de chuva mansa (Figura 43) .

Figura 43. Frange, Lucimar. Cartas de vírgulas paradas tênues. 2012. Fonte: acervo da artista.

Sobre este trabalho, Frange diz

[...] livro Cartas Hélio Oiticica/Lygia Clark 1964/1974 xerox das páginas com a palavra "carta" risco com lápis aquarela azul, por cima das linhas onde não havia "carta" cada página no chão, sob chuva muito fina suaves cuidados cada papel é levado para o estúdio decalcado com papel toalha de cozinha quase-nada de cartas 13 desenhos, de $40 \mathrm{~cm}$ x $22 \mathrm{~cm}$ lembro Marco Zero, das italianas Kátia Meneghini e Valentina Vetturi, a brasileira Vera Uberti, Os lava-vidros performances, ações de lavar os vidros dos carros, na Praça da Sé, marco zero de São Paulo onde se medem todas as distâncias da cidade onde se desenvolve um grande núcleo urbano paulista. $O$ ato de lavar vidros é ação de meninos ditos "de rua"180.

${ }^{180}$ FRANGE, Lucimar. Cartas de chuva mansa. 2012. Fonte: acervo da artista. Disponível em www.lucimarbello.com.br. 
Mais tarde, por meio de fragmentos aleatórios das Cartas de vírgulas, paradas tênues ${ }^{181}$ (Figuras 44), nasceram as Cartas de polifonia balbúrdia (Figura 45). Essas cartas formaram a exposição "Carta cura corte" (Figura 46), na Galeria Acervo da CAL, com curadoria de Irene Tourinho, professora aposentada do Programa de Pós-Graduação em Arte e Cultura Visual da Universidade Federal de Goiás. Espalhadas pelas paredes e pelo chão da galeria, as palavras produzidas em papel, lápis aquarelado, água do mar e da chuva, estavam ao alcance do público (Figura 47).

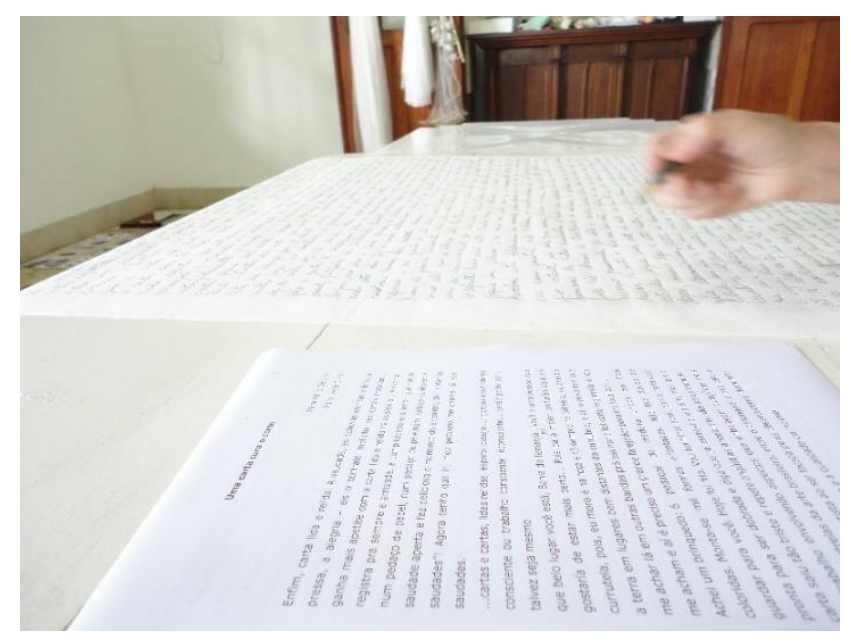

Figura 44. Frange, Lucimar. Cartas de vírgulas paradas tênues. 2012. Fonte: acervo da artista.

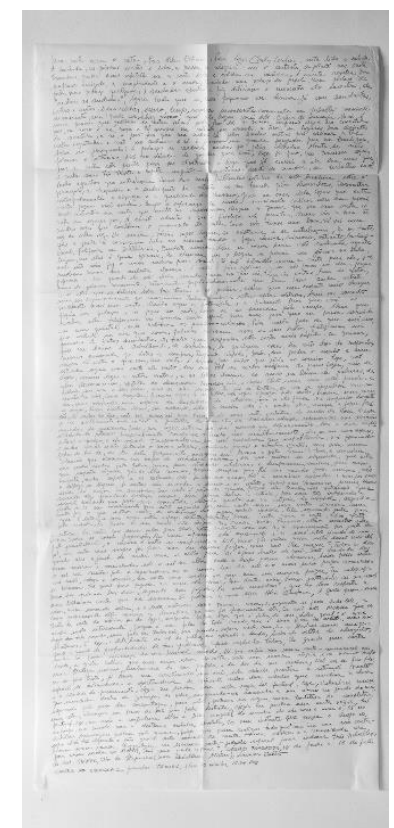

Figura 45. Frange, Lucimar. Cartas de vírgulas paradas tênues. 2012. Fonte: acervo da artista.

181 FRANGE, Lucimar. Cartas de vírgulas paradas tênues. 2012. Fonte: acervo da artista. Disponível em www.lucimarbello.com.br. 


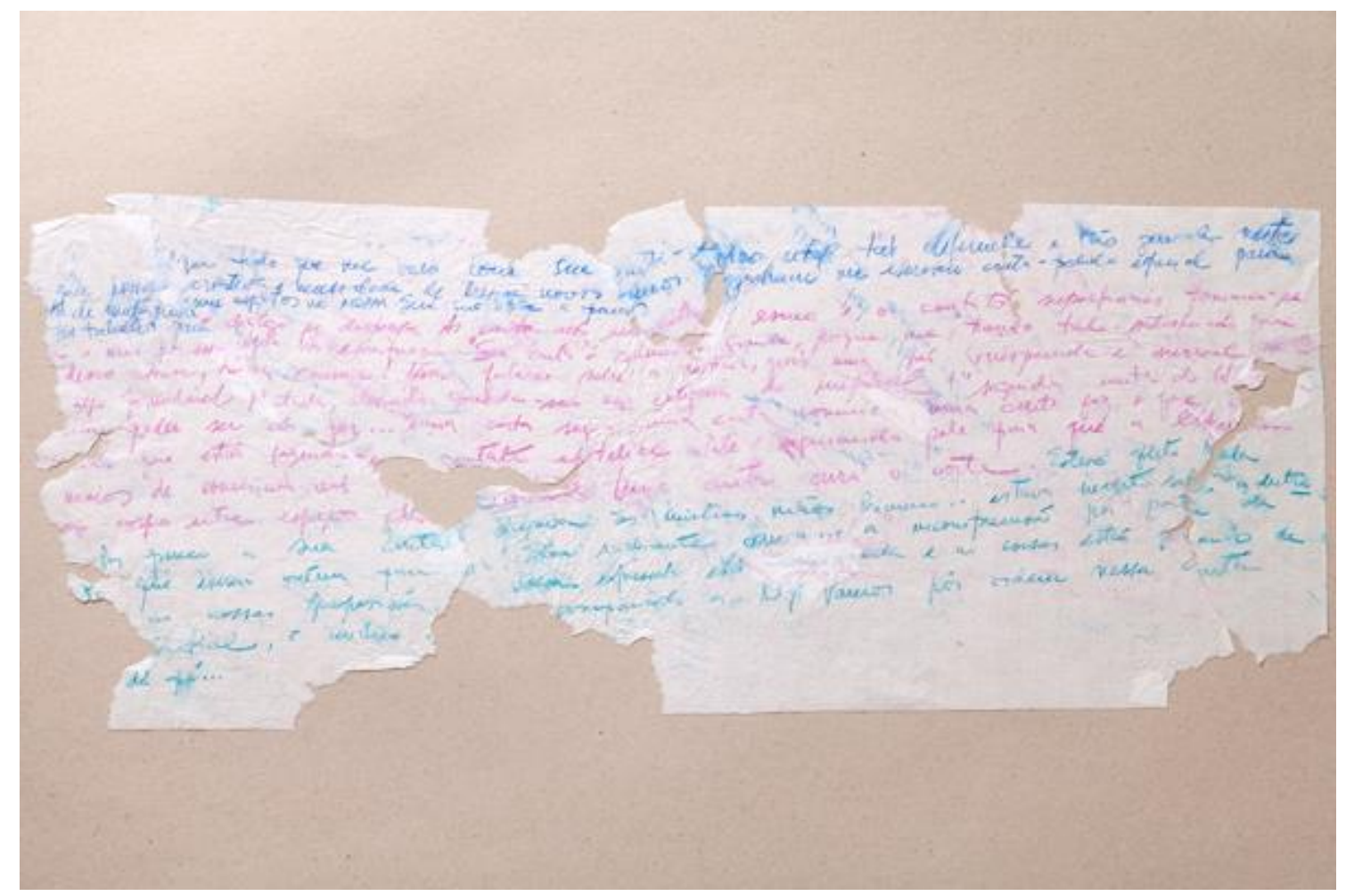

Figura 46. Frange, Lucimar. Cartas de polifonia balbúrdia. Fonte: acervo da artista.
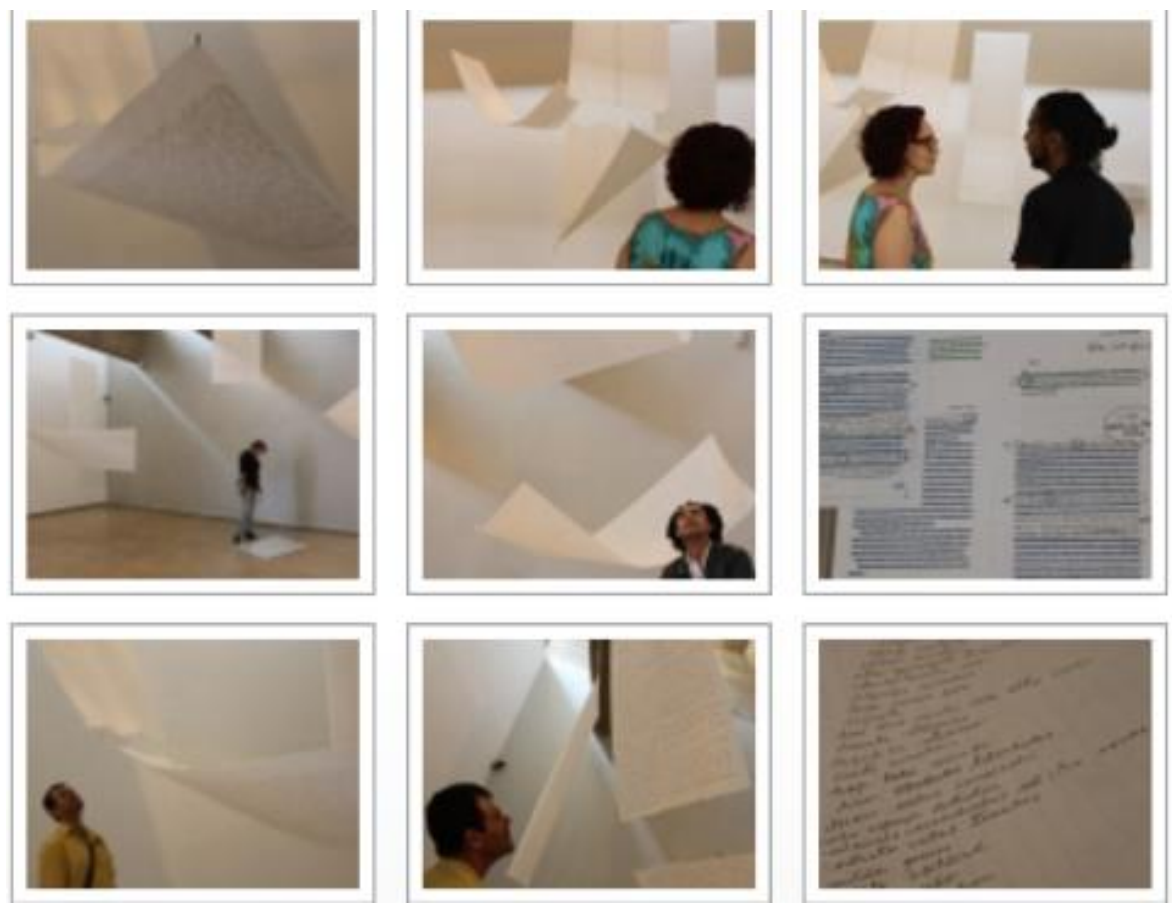

Figura 47. Exposição "Carta cura corte", Lucimar Bello Frange. CAL-UFV, 2013. Fonte: acervo da artista. 
Os modos de Frange operar, de constituir a imagem, quando acionados em experiências coletivas, assumem os mesmos princípios de sua poética como artista. Quando arte e educação se propõem a intervir na direção da transformação social, como acontece em seu trabalho, pode-se objetivamente inferir uma dimensão política e estética em comum entre ambos, tomando como base $o$ conceito de partilha do sensível de Jacques Rancière.

\begin{abstract}
A partilha do sensível faz ver quem pode tomar parte no comum em função daquilo que faz, do tempo e do espaço em que essa atividade se exerce. Assim, ter essa ou aquela "ocupação" define competências ou incompetências para o comum, dotado de uma palavra comum ${ }^{182}$.
\end{abstract}

São duas noções que estão implicadas neste conceito. A primeira é a de que existe participação no plano comum, que dá forma à comunidade e, por conseguinte, ao recorte desse comum sensível em partes espaciotemporais estabelecida pela existência dos corpos, das práticas, dos discursos e dos processos de subjetivação. A segunda, pelo seu recorte em tempos de ocupações. O que reporta relações de inclusão e exclusão, dos regimes que organizam os modos de ver e de dizer, que abrem fissuras nas quais a negociação dos sentidos acontece ...

[...] como um sistema das formas a priori determinando o que se dá a sentir. É um recorte dos tempos e dos espaços, do visível e do invisível, da palavra e do ruído que define ao mesmo tempo o lugar e o que está em jogo na política como forma de experiência ${ }^{183}$

O trabalho desenvolvido por Frange na llha de Itaparica, não se apresenta como um plano de igualdade e identidade entre os participantes, sendo que não é um a priori, mas algo a ser constituído. Quando transporta sua poética para o plano do compartilhamento formativo, identifica a arte com as próprias formas assumidas pela vida, como manifestações do lugar, das pessoas, em um processo em que a experiência sensível é capaz de dar contornos a um novo corpo, cujo caráter ativo da educação estética se dá nas situações em ato, em um processo de mediação em que as relações cognitivas não são previsíveis.

182 RANCIÈRE, Jacques. 2005, p.16.

183 Idem, p.16. 
Nos percursos poéticos que se sucedem na llha de Itaparica, Frange utilizou de cópias de xerox realizadas a partir de fotos de cinco oficinas desenhantes (proposições com crianças, pescadores, trançadeiras de cabelos, cozinheiras, entre tantos outros, e apresentou o "Fazeres de mãos", um resultado construído por meio da percepção e saberes da própria comunidade da ilha (Figuras 48 e 49).
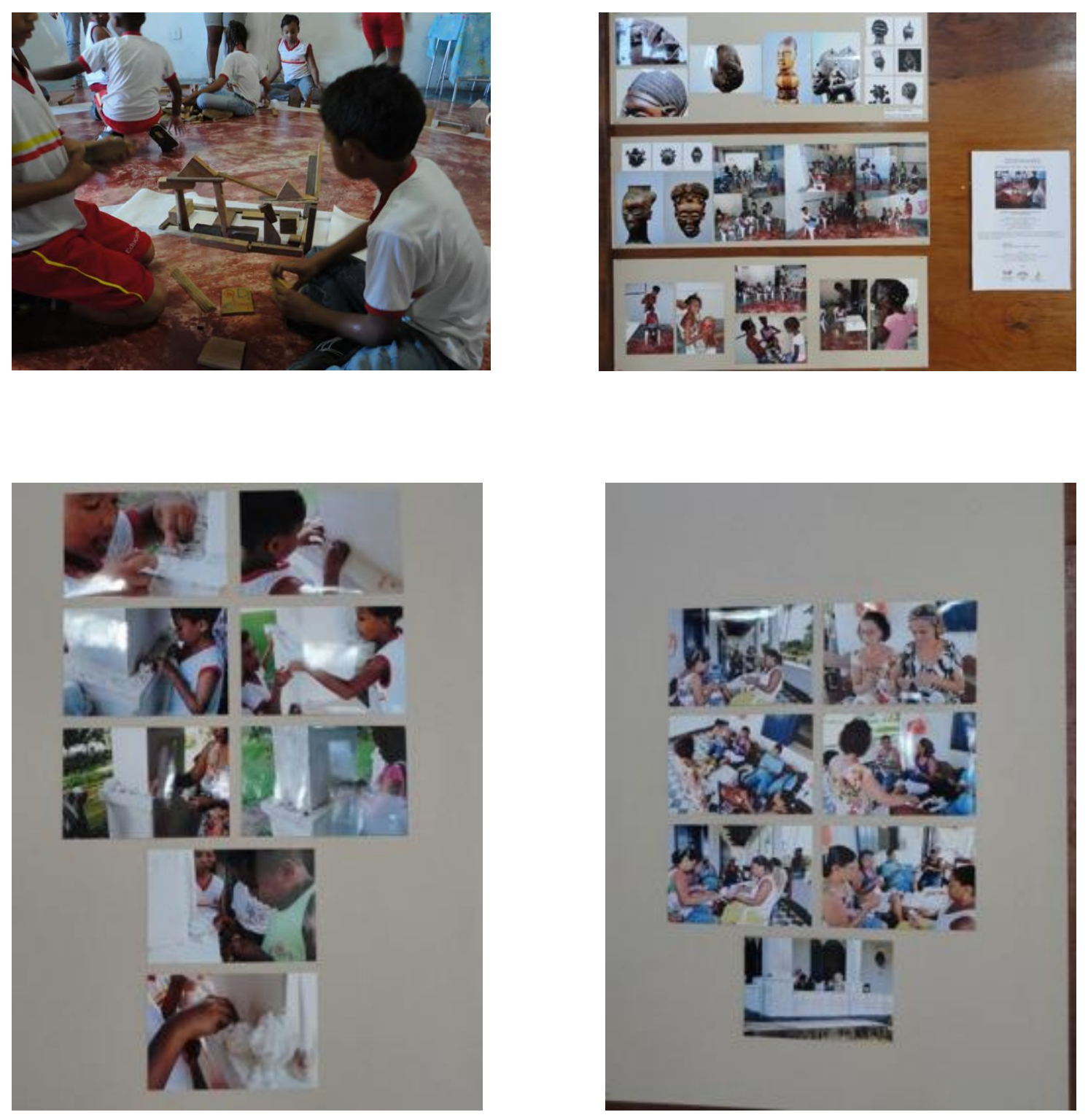

Figuras 48. Saberes da llha de Itaparica. Exposição resultante dos trabalhos realizados nas oficinas desenhantes: Desenhos de Comer, para Itaparica; Desenhos de CONCHAS e Desenhos de Pipocas, saberes ancestrais; Desenhos de pente.AR, africanIDADES; Desenhos de FAZER MAR e Desenhos de QUINTAS PITANGAS. 2011. Fonte: Acervo da artista. 


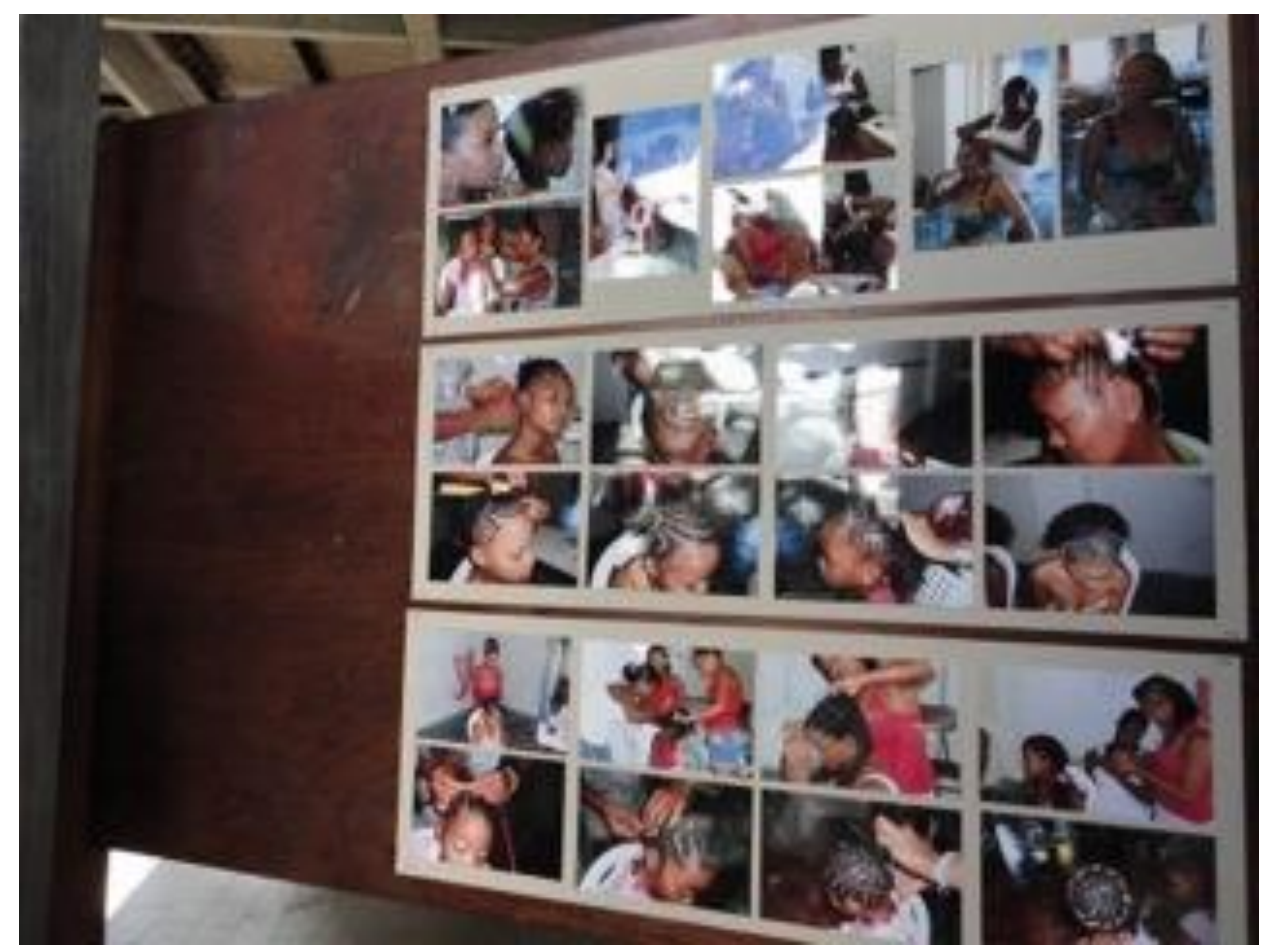

Figura 49. Saberes da llha de Itaparica. Exposição resultante dos trabalhos realizados nas oficinas desenhantes: Desenhos de Comer, para Itaparica; Desenhos de CONCHAS e Desenhos de Pipocas, saberes ancestrais; Desenhos de pente.AR, africanIDADES; Desenhos de FAZER MAR e Desenhos de QUINTAS PITANGAS. 2011. Fonte: Acervo da artista.

Em "desenhos de comer, para Itaparica", trabalho realizado no ano de 2011, a artista mostrou como se apropria dos elementos locais, da realidade tátil e simbólica dos objetos comuns para ativar o processo de criação e compartilhamento de experiências. A matéria _ papel manteiga (o mesmo que habita as cozinhas) recortado na forma da ilha, pedaços de madeira e retalhos pintados com colas coloridas. A motivação _ a vontade de realizar desenhos de comer, que surge de sua visita à maquete de Salvador, na Festa dos Ogãs. É importante destacar que o termo ogã, no dialeto iorubá, significa chefe em um terreiro de Umbanda ou Candomblé. No terreiro exercem várias funções, dirigem trabalhos, zelam santos e filhos de santos, tocam atabaques. Os ogãs não incorporam, mas são dotados de grande intuição, percebendo os fatos ao seu redor $^{184}$.

$\mathrm{Na}$ experiência proposta por Frange, a maneira de perceber o que envolve o entorno, a materialidade das coisas passa a não ser um mero objeto que

\footnotetext{
${ }^{184}$ Depois de participar de inúmeros trabalhos nos terreiros de Umbanda, o autor se familiarizou com os termos e vocabulários da religião.
} 
significa, mas atua como índice da memória de cada participante, que passa a estabelecer conexões tomando como base as suas vivências anteriores. Não são necessários materiais convencionais para que os saberes da arte se ativem na educação. A realidade local, que traz o encontro com a fé, com as festas religiosas, com as formas de habitar, com as maneiras de comer, são materialidades e imaterialidades articuladas esteticamente. Nas ações de Frange, os limites da vida ordinária são transcendidos por meio das manobras poéticas. Questões mais amplas, relacionadas aos papéis da arte dentro das diferentes culturas e os valores estéticos que delas podem emanar, permite uma diversidade de significações.

Há sempre a multiplicidade que está contida no local, no lugar onde se vive a experiência, e a partir delas é possível mobilizar o repertório dos sujeitos, que articulado pelas práxis artística, ativa 0 ato criador, a capacidade de compreender, relacionar, ordenar, configurar e significar. Dessa forma, as atividades comuns exercidas no cotidiano se transformam, tornando possível que "cada atitude e cada gesto, cada sentença, cada palavra, produzam mais do que uma flutuação na intensidade da emoção fundamental; isto é, uma mudança de forma e de coloração em sua qualidade"185.

Uma concepção na qual, tanto o educador, quanto ...

[...] o artista só realiza sua performance na medida em que é criador, sujeito de pensamentos inquietos, múltiplos e ambíguos, a convocarem novas ações, novos fazeres, outros saberes, jamais "verdadeiros", mas saberes que contenham os efeitos de sentido da dúvida e das incertezas, da experimentação e experienciação. A arte [...] na comunidade e na sociedade só acontece se a liberdade de criar e de ser, estiver como valor do valor, tanto no inteligível quanto no sensível ${ }^{186}$.

Um dos grandes obstáculos para o entendimento das práticas artísticas contemporâneas é o fato de ela ter se tornado muito próxima à vida. No entanto, como é possível perceber na trajetória da artista, pesquisadora e educadora, que é mais extensiva do que poderia ser tratado nesta investigação, pode-se, a partir

\footnotetext{
185 Dewey, John. 2010, p. 121.

186 FRANGE, Lucimar Bello. Arte, cultura e educação; Alguns pressupostos. Caderno de Discussão do centro de Pesquisa Sociossemiótica. São Paulo, 2001. Pp. 231-232.
} 
das inferências documentais, apresentar o que seus percursos trazem para compreensão de tais práticas, do conceito de imagem e da maneira como os articula ao processo educacional visando a compreensão da experiência. No Quadro 06 estão sistematizados os dados capturados por meio desse método de análise de documentos. 
Quadro 06: Derivações da análise documental - Trajetória

\begin{tabular}{|c|c|c|}
\hline PRÁTICA ARTÍSTICA & IMAGEM & PROCESSOS PEDAGOGICOS \\
\hline $\begin{array}{l}\text { - A prática artística surge como um } \\
\text { processo de experimentação. } \\
\text { - As temáticas abordadas nesse } \\
\text { processo estão sempre relacionadas } \\
\text { ao cotidiano em suas formas mais } \\
\text { simples (passear, habitar, comer, } \\
\text { conversar) } \\
\text { - Os elementos materiais e imateriais } \\
\text { compõem um corpo semântico não } \\
\text { hierarquizado, em que o ato de } \\
\text { compor as formas envolve o } \\
\text { referencial histórico da arte, tendo o } \\
\text { tempo como uma dimensão não } \\
\text { linear. } \\
\text { - A dimensão espacial é tomada como } \\
\text { um fundamento, como um } \\
\text { personagem que oferece materiais e } \\
\text { possibilidades poéticas para } \\
\text { hibridação da linguagem do desenho } \\
\text { com outras linguagens artísticas; } \\
\text { - Se apresenta em contextos que se } \\
\text { fundem aos processos subjetivação; } \\
\text { - Palavras, ações e coisas têm o } \\
\text { mesmo grau de importância no } \\
\text { processo de criação constituindo-se } \\
\text { como elementos composicionais; }\end{array}$ & $\begin{array}{l}\text { - A imagem é percebida como um conjunto } \\
\text { de operações, ações e interpretações; } \\
\text { - Não reside apenas na materialidade do } \\
\text { objeto proposto e ou exposto; } \\
\text { - Assume os contornos de todo o processo } \\
\text { de criação; } \\
\text { - Textos visuais, verbais, são } \\
\text { incorporados na produção da imagem e } \\
\text { adensam as relações entre significantes e } \\
\text { significados; }\end{array}$ & $\begin{array}{l}\text { - A arte é percebida como uma dimensão do } \\
\text { ser humano, não como uma atividade; } \\
\text { - A relação com as imagens partem das } \\
\text { conexões por elas propostas, que são } \\
\text { aprofundadas na medida em que têm suas } \\
\text { ressonâncias na construção dos percursos } \\
\text { geradores de sentidos e significações } \\
\text { propostas nas experiências; } \\
\text { - Não há um saber a priori onde se deve } \\
\text { chegar. O que define a constituição de } \\
\text { saberes é a relação concomitante e } \\
\text { intrínseca ente os planos da expressão e o } \\
\text { plano de conteúdo. } \\
\text { - As competências dos sujeitos na relação } \\
\text { com o estético estão diretamente vinculadas } \\
\text { e são respeitadas como conteúdos que se } \\
\text { mesclam à dimensão sociocultural; } \\
\text { - Os elementos formais, leia-se elementos } \\
\text { composicionais (planos, linhas, luzes, } \\
\text { espaços, equilíbrio, textura), são abordados } \\
\text { em sua interação com os conteúdos em } \\
\text { relações intertextuais; } \\
\text { - O sentido, no processo educativo, não estáá } \\
\text { nos objetos da arte, no reconhecimento de } \\
\text { suas formas, que gera um processo de } \\
\text { dedução. Mas nas possibilidades de relação, }\end{array}$ \\
\hline
\end{tabular}




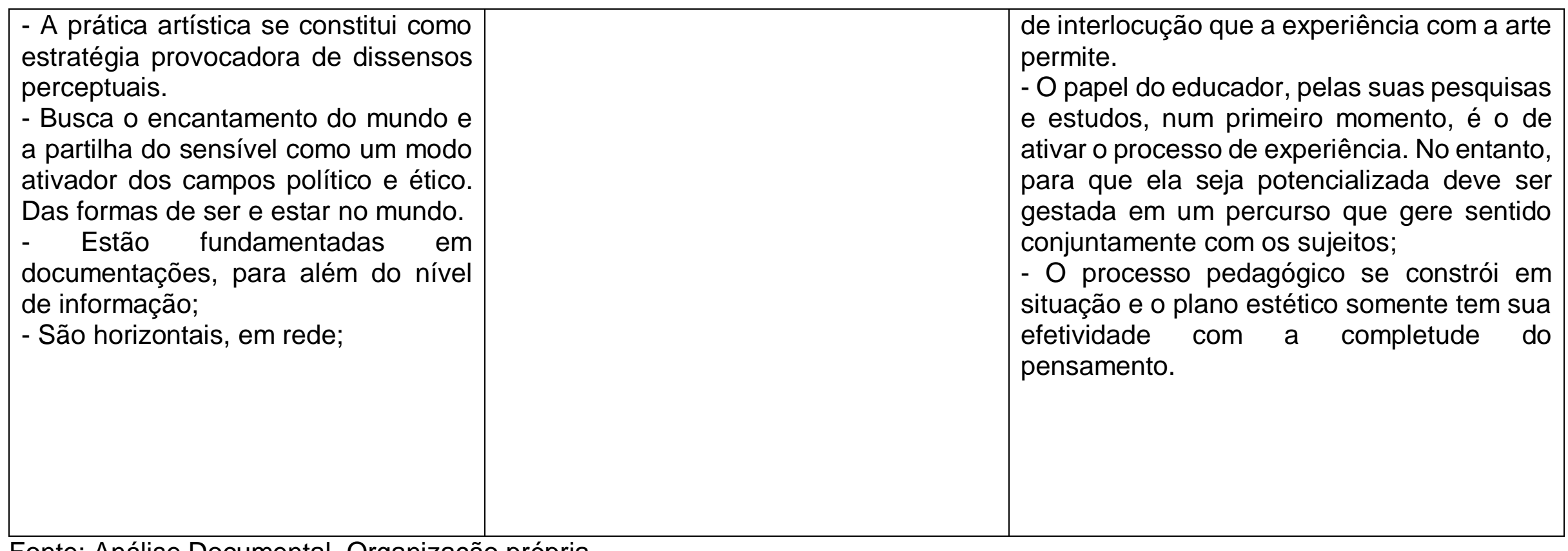

Fonte: Análise Documental. Organização própria 


\subsection{Análise e Interpretação de Entrevistas}

As entrevistas realizadas com 0 ator chave, após o processo de transcrição e conferência, foram fragmentadas e organizadas conforme as categorias de análise. Em função da centralidade desse método e da riqueza do material recolhido, tal procedimento favoreceu o processo de análise $\mathrm{e}$ interpretação dos resultados. A análise e interpretação da poética de Frange por meio das entrevistas forneceu elementos para que se possa, como base no multimétodo proposto, trazer o devido aprofundamento ao objeto de pesquisa. Vale ressaltar, que a entrevista é sempre uma produção intersubjetiva, de onde surgem as informações objetivas, de interpretação e análise.

Assim, seguindo a estrutura proposta são destacadas nas entrevistas as categorias de análise separadamente (práticas artísticas, imagem e processo pedagógico). No entanto, propõe-se a cada seguimento das entrevistas, o diálogo como um processo criativo, em que as evidências, indícios/imagens/palavras/gestos guiem os sentidos enunciados e os significados percebidos. Adicionalmente, quatro artistas contemporâneas, também entrevistadas no percurso de pesquisa, são trazidas ao diálogo com o ator chave nessa parte ${ }^{187}$.

\subsubsection{As Práticas Artísticas por Lucimar Bello Frange}

O argumento central para que se possa adentrar à reflexão sobre as práticas artísticas de Frange, parte da compreensão de que aquilo que chamamos de arte contemporânea, não é, como se costuma definir, uma categoria cronológica na história das artes visuais. Mas, sobretudo um novo paradigma que deve ser atentamente observado e pesquisado no campo educacional como um processo que envolve o enlaçamento íntimo entre objetos e ações humanas, com o propósito de compreender o conjunto de estruturas simbólicas e de valores que por ela são mobilizados nos planos, tanto da

187 Com vistas a preservar a identidade das entrevistadas, seguindo o protocolo de pesquisa, serão omitidos os nomes e substituídos pelas siglas AE1, AE2, AE3 e AE4, conforme esclarecido no capítulo metodológico. 
experiência individual artística, quanto em suas proposições relacionais que envolvem a educação.

O processo tem seu início com uma conversa informal, em que Frange fala sobre o desejo de iniciar um trabalho em vídeo.

\begin{abstract}
Estou pensando em fazer um vídeo. Mas para fazê-lo vou precisar me deixar na calçada... Não dá! Não dá porque vão me catar ou vão me chamar de louca. [...] É só a calota. Claro que pega o movimento da roda, porque a calota vai estar em movimento. [...] Lindos! Eu já fiquei à beira dos sinais, assim ... (faz um gesto como se usasse um binóculo). [...] Um monte de rodas...é uma coisa prateada, que a medida em que está no sol tem reflexos, uma coisa que escapa também. O movimento acelerado, ao mesmo tempo impreciso e de luz que escapa. Essas coisas todas me interessam. E aí depois eu queria jogar isso com palavras ${ }^{188}$.
\end{abstract}

Não há, no processo que dá início à criação, a abordagem de grandes temas. O movimento, aquilo que passa quase desapercebido se destaca na percepção. São calotas, um acessório para automóveis que, a princípio, não remete a nada a não ser a um objeto que se distingue um do outro, em função do poder aquisitivo de seus proprietários ou como algo decorativo. No entanto, há em sua observação quatro elementos que se relacionam de maneira efetiva em seu processo de criação. O primeiro está relacionado ao próprio corpo, à uma distância, à proximidade ou afastamento daquilo que se percebe como a exemplificação de um contexto complexo. O segundo, a maneira como procura destacar deste contexto as questões estéticas que serão mobilizadas (movimento, cor, luz). O terceiro refere-se à linguagem utilizada como meio expressivo.

A adequação dos elementos que dão sentido à produção da imagem, a um meio pelo qual vai se efetivar, são compreendidos por Frange como algo que é da ordem da invenção/criação. Finalmente, há um quarto elemento, a palavra. Frange tem como livro de cabeceira um dicionário analógico ${ }^{189}$. O embate com a palavra/imagem é constante em seu processo de criação. Está presente em seu trabalho desde os registros que são incorporados em percurso até o produto

\footnotetext{
188 FRANGE, L.B. Lucimar Bello Frange: entrevistas realizadas em 2016. Entrevistador: Carlos W. M. de Souza, meio digital de gravação, 2016.

189 O dicionário analógico é o que reúne as palavras, em grupos analógicos segundo sua afinidade de ideias. AZEVEDO, Francisco Ferreira dos Santos. Dicionário Analógico da Língua Portuguesa. Ideias Afins. Thesaurus. Ed. Lexikon, 2010.
} 
final. Um elemento que nasce na poesia, particularmente, na poesia concreta que tem em sua essência a subversão da poesia como resultado apenas da palavra escrita. Nesse sentido, parte da construção e incorporação subjetiva do elemento visual. A disposição de letras, união entre texto e imagem para uma completa significação. Muitas vezes estabelece jogos de palavras que se sustentam em recursos não só visuais, mas nas aliterações e assonâncias, ou seja, na repetição do mesmo som consonantal e do mesmo som vocálico. Este é um dispositivo utilizado na poesia concreta ${ }^{190}$. Não por acaso, o recurso vem sendo utilizado pela artista na composição de vídeos. O que se define como verbo-voco-visual é típico do enunciado fílmico, onde o arranjo estético, sua arquitetura, é elaborada por meio de blocos de sensações em que ...

[...] há um aqui e agora que vai acontecendo, você vai tecendo uma engenhoca, você vai construindo um outro aqui e agora que é extremamente singular. Não é autoral, eu acho que é extremamente singular. São milhões de contaminações que nem você dá conta, de onde, de quando, de como. Você não consegue mapear isso ${ }^{191}$.

Nesse sentido, se reporta à maneira como os dispositivos tecnológicos vêm agregando ao processo de criação/invenção como forma de imprimir a subjetividade, como algo que supera a própria função para o qual foi criado (Figura 50).

[...] Nesse mundo tecnológico... isso é demais! Eu acho uma maravilha estar vivendo o que eu vivo hoje. E acho passivo você chamar uma possibilidade de comunicação e de estar no mundo de outro jeito de ferramenta. Não é ferramenta, ferramenta é martelo. A ferramenta tem uma função. A tecnologia e o mundo virtual vão além da função. Ó eu vou desenhar a tarde inteira (risos) $)^{192}$

\footnotetext{
190 Poesia concreta é um tipo de produção literária de caráter experimental, basicamente visual, que busca estruturar o texto poético a partir do espaço do seu suporte. É evidente a influência dos movimentos Concreto e Neoconcreto no percurso de Frange. O movimento concreto surgiu no Brasil e na Suíça na década de 1950, sendo nomeado pelo poeta Augusto de Campos, em 1955.

191 FRANGE, L.B. Idem, 2016.

192 FRANGE, L.B. Ibidem, 2016.
} 


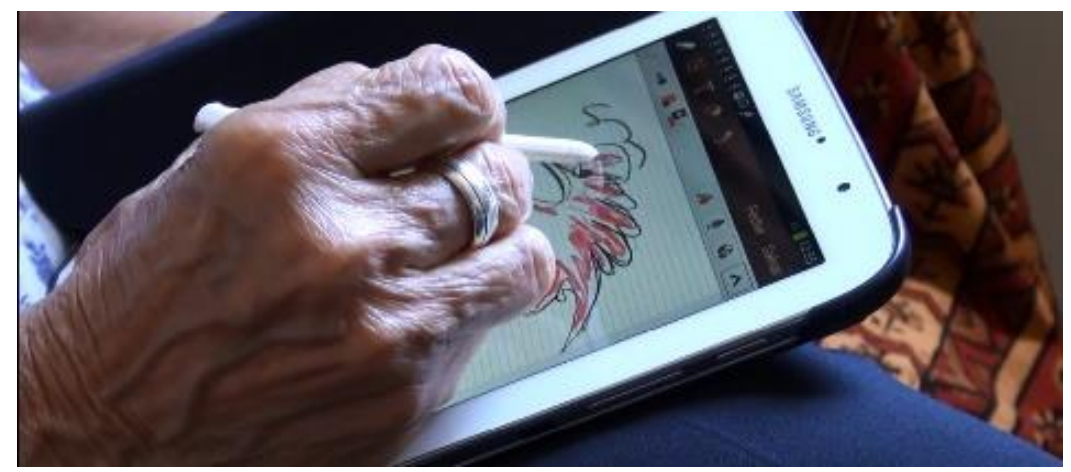

Figura 50. Fotografia: Carlos Weiner. Lucimar Bello Frange desenhando, experimentando o suporte digital que estava sendo utilizado na entrevista. 2014.

Para Deleuze e Guattari, a arte conversa e é a única coisa que conversa no mundo que se conversa ${ }^{193}$. A capacidade de mobilizar sensações e romper com o conservadorismo de cada época, vence o tempo e dialoga com futuro. Frange fala de um presente que é futuro, que possibilita um processo de criação em que a ...

[...] a presença é também virtual. A presença hoje não é só física. $A$ presença é virtual também. De um tempo para cá eu fico muito em casa. Mas eu converso com milhões de pessoas, encontro, trabalho, escrevo junto. Quer dizer, você não encontra fisicamente, mas você encontra de um outro modo, de uma outra relação. E acho até que muda muito. Ás vezes, o contato virtual é mais caloroso que o contato físico. Quando eu tratei...os postais...quando fiz o pós-doutorado, com a Suely Rolnik, fiquei muito tempo utilizando o photoshop. (Um breve intervalo) as imagens as fotografias do edifício. Você está trabalhando, envolvido com um certo modo de fazer, mas é ruim... (Lucimar continua desenhando). Para nossa geração o problema com os equipamentos eletrônicos é que eles não vêm com um menino de 12 anos junto. (risos) $[\ldots]^{194}$

Embora considere os aspectos facilitadores das novas tecnologias para o processo criativo, para que as práticas artísticas individuais e coletivas se desenvolvam no campo das virtualidades, há um apesar, que traz o encontro físico como algo imprescindível. No período de mais de dois anos que passou fotografando a obra em construção ao lado de sua residência e imersa no processo do pós-doutoramento, sentiu de maneira bastante contundente a

${ }^{193}$ DELEUZE, G. F. GUATARRI. O que é filosofia? Tradução Bento Prado Jr. e Alberto Munõz. São Paulo:Ed.34, 1992.

${ }^{194}$ FRANGE, Ibidem, 2016. 
maneira como, apesar do processo criativo, que por vezes é um lugar de solidão, o jogo da produtividade dos encontros constitui um fator essencial, que ativa implicações mútuas nos fluxos das experiências e alteridades de uma outra maneira.

$\mathrm{Na}$ fala da artista, de certa forma, define um território em que a arte, a prática artística não reporta à informação, mas à formação, como ela mesma diz "corpada e co-corpada". Trata-se da experiência intensificada, concentrada, exponenciada, aquela que retira o homem da monotonia do cotidiano (da fôrma), resignificando ${ }^{195}$. Afirma que

[...] não há como não existir a forma. A minha briga é com a "fôrma" e a "fórma". A "fôrma" que eu continuo colocando acento circunflexo e coloco entre aspas e a "fórma" que eu coloco acento agudo e coloco entre aspas. [...] $]^{196}$

Há nessas expressões um jogo que não se refere apenas à questão semântica, que implica nas palavras escritas com a grafia "fora" das convenções ortográficas. O que remete a Manoel de Barros, quando diz que "a rede era vasilha de dormir. Traços de letras que um dia encontrou nas pedras de uma gruta, chamou: desenhos de uma voz. Penso que fosse um escorço de poeta". Trata-se de um estado de invenção inquieta, no qual a materialidade surge e desaparece, dá sentido a um conhecimento que não se fixa, busca o entrelaçamento para que surja um jogo de pensamento do qual se depreende o inesperado. O fluxo de criação em Frange, aceita que

[...] 0 ato e o acontecimento sejam matéria. Depois vira vídeo, é volátil. $O$ ato real, se é que a agente pode falar real, virou vídeo, o vídeo me diz que ele aconteceu. Me coloca em outro tempo aquilo que era ontem, mas que é agora, que é aqui, que é já. Que não difere para mim de uma pintura, de um desenho. A gente estava falando da Cláudia França, não difere de um desenho da Cláudia França assinado nos anos 80, anos 90. O trabalho da Maria Eugênia Matricardi, que é do ano passado. Que ele tem um vínculo com o momento atual, do país inteiro na rua, e ela vai para os pratos do congresso, em Brasília, ela não vai para um lugar qualquer, ela não vai para uma rua qualquer. Ela fica na frente daqueles pratos e dizendo venha! O jato de água está comendo aquele corpo nu, ela se debatendo e dizendo venha, venha, vem mais! Quer dizer, é muito finamente político, tanto quanto ficar escarnando três dias com uma roupa branca, até ficar toda ensanguentada. É matérico também. A matéria água está aqui, a

195 DEWEY, John. 2010.

196 FRANGE, L.B. Ibidem, 2016. 
matéria corpo está aqui. Não está a pintura em tela. Mas a escultura está ali viva em uma situação de ato, que tem a ver com o que você estava falando ${ }^{197}$

Três dimensões da existência humana, espaço, tempo e matéria, se entrelaçam na produção artística. Sobre isso, Frange remete ao trabalho de outras artistas contemporâneas, indicando os traços comuns. É o que se vê na produção das artistas Cláudia França e Maria Eugênia Matricardi (Figuras 58 e 59). São poéticas distintas, que não se assemelham à sua, mas que, no entanto, trazem algumas questões pertinentes para compreensão das práticas artísticas contemporâneas e, particularmente, seu modo de operar.

Nessa perspectiva, a artista AE2 contribui para a reflexão ao apontar que

[...] Para mim, enquanto artista, interesso-me por detalhes e passagens quase imperceptíveis do cotidiano. A ideia é que na materialidade das instalações, o visitante construa analogias entre o que está a perceber e flashes seus que ficaram desapercebidos na sua vida. Como se fosse um encontro de invisibilidades, no visível (e palpável). Acabo de escrever um texto sobre uma página em branco encontrada ao acaso, estou ainda impregnada disso. ${ }^{198}$

Ainda que seja um tema aberto a múltiplos recortes e interpretações, o espaço na arte contemporânea não deve ser compreendido de modo literal. Ou seja, não pode ser pensado, apenas por meio de suas características físicas, como um suporte onde algo acontece. Como aconteceria com uma pintura, a exemplo. O espaço é tomado como um elemento composicional identitário, representativo de poderes e relações interpessoais. No trabalho de Matricardi, citado por Frange, há um valor simbólico de existência, um confronto entre o público e o privado, que pela ação estética transforma o corpo em um elemento desestabilizador das significações e ocupações do espaço pelo outro. Em sentido não contrário, mas analógico, o espaço em Cláudia França torna-se um elemento delicadamente instável, onde os objetos auto representacionais invadem os territórios do gênero, da memória e da corporeidade, sem perder o vínculo histórico com o desenho como forma expressiva (Figuras 51 e 52).

${ }^{197}$ FRANGE, L.B. Ibidem, 2016.

198 Fragmento da entrevista concedida pela artista educadora AE2, em 2016, a Carlos W.M. de Souza. 


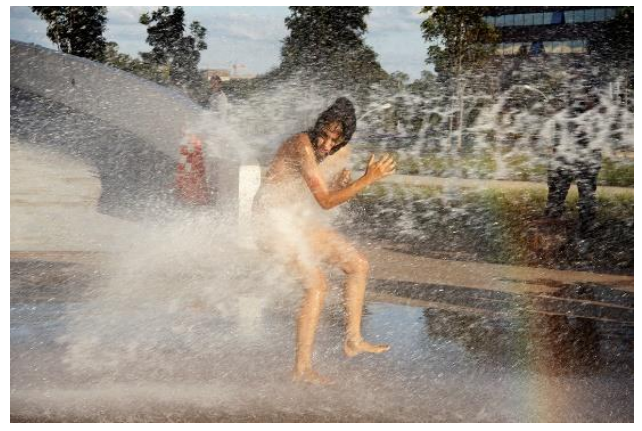

Figura 51. Maria Eugênia Matricardi Performance: "Corpo contra conceito". Brasília - DF. 2013. Fonte: site da artista.

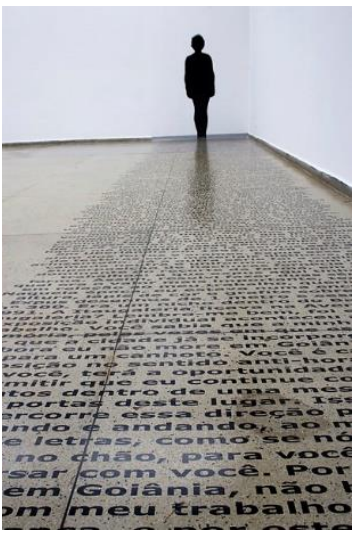

Figura 52. Cláudia França Performance: "Cic I o ne". Campinas - SP. 2010. Fotografia Antônio Scarpinetti. Fonte: Acervo da Artista.

Ao se reportar ao tempo e à matéria, Frange aborda a relação entre imaterialidade/materialidade da ação poética, em que depois do ato realizado, fica o registro. Além disso, traz a ambiguidade do tempo, um aqui e agora, que pelo registro alcança a perseverança de estar no mundo. Registro é memória (individual e coletiva), é um documento tão imprescindível quanto um texto histórico. A diferença está no fato de que o documento, não é estético porque é histórico, mas é histórico porque é estético, é uma ação no mundo que promoveu um desvio nas maneiras de perceber em um determinado espaço e tempo, que pode ser acessado, refletido e sentido de outras maneiras em outros espaços e tempos.

[...] O meu raciocínio é de desenho, ele vem de meados dos anos 60. Quando eu resolvi fazer Belas Artes, em 1967, eu já tinha uma certa habilidade para desenhar. Por exemplo, se eu quiser fazer o seu retrato, sei fazer e fica se parecendo com você. Mas isso não me interessa. Eu poderia até ganhar com isso. Tem um certo saber desenhar que eu fui exercitando quando era pequena, me deixaram fazer e eu fui aprendendo, fui descobrindo algumas engenhocas, jeitos de combinar linha com linha, que dá um possível retrato seu. Mas isso é um saber sabido, não em interessa. Prefiro muito mais ir trabalhar com desenho, sabores e cheiros e provocar uma outra coisa nas pessoas que nem eu sei o que é. Isso me tira o chão. Do que ficar nesse já sabido, um certo arranjo. Isso vem desde os meados dos anos 60, e 67 quando eu fui fazer artes e querer esse rumo como profissão. Isso é de 1967, o dia em que coloquei os pés nas Belas Artes. Mas cheguei nas Belas Artes e já passei uma junta de tampão de motor em na prensa de gravura em metal, com tinta, mandei para um salão, 
dizendo que era gravura e já levei paulada (risos). Porque a metade das pessoas, dos artistas que estavam no salão diziam que aquilo não era gravura. Que eu não tinha gravado nada, que eu simplesmente tinha pegado uma junta de tampão de motor, passado tinta e passado na prensa. E eu perguntava qual é a diferença entre você desenha em uma chapa virgem, passar tinta e passar para o papel? Para mim nenhuma. Aquilo era uma junta de tampão de motor, estava virgem...fui lá e entintei com a tinta que eu fiz, produzi a cor que eu quis, e dei a forma que eu quis. Eu recortei aquilo. E era minha gravura, ganhei um prêmio $^{199}$

No decorrer do texto, tanto a questão da mudança perceptual que abrange os anos de 1950, com maior ênfase os anos de 1960 - 70, como o desenho como referência no processo de criação da artista, já foram abordadas. No entanto, emergem questões, no que concerne à política sensível das práticas artísticas, que são imprescindíveis à reflexão - o encontro discordante da percepção (material e imaterial) e uma atitude ante o inesperado. Se a primeira diz respeito a não aceitar o que se sabe como referência da verdade, a segunda rejeita a verdade de um meio como único caminho para se chegar ao resultado.

Dewey define esta tensão como resistência. Afirma que a existência deste fenômeno define "o lugar da inteligência na produção de um objeto artístico"200. É um modo de refazer as experiências passadas, com o propósito de que sejam incorporadas a um novo padrão. Não se trata de habitar essas experiências e saberes como são e, menos ainda, de descarta-los, em busca de uma novidade inconsistente. Mas, sobretudo, de descobrir a natureza da forma em um processo que contém o inesperado, a descoberta. Estes elementos, nas práticas artísticas contemporâneas, não passam por um formalismo ou hierarquia de técnicas e materiais, mas pela compreensão de que

[...] a forma é um vazamento daquilo que está no seu corpo. Ela não é uma fabricação que você faz, é um corpo que vaza. A Suely Rolnik diz que "o artista não cria, mas que ele dá passagem àquilo a que ele é obrigado a ...". Eu concordo com a Suely Rolnik ${ }^{201}$, fica pulsando, pulsando, pulsando, ou você dá forma para aquilo, ou você enlouquece. Aí você dá forma. Artista profissional.

\footnotetext{
199 FRANGE, L.B. Ibidem, 2016.

200 DEWEY, John, 2010, p.265.

${ }^{201}$ Suely Rolnik é psicoterapeuta, crítica cultural (nas revistas Parachute, canadense e Zehar, espanhola), professora e integrante do Núcleo de Estudos da Subjetividade da Pontifícia Universidade Católica de São Paulo e professora convidada do Programa de Estudos Independentes do Museu de Arte Contemporânea de Barcelona (MacBa). Foi orientadora de Lucimar Bello em seu pós-doutorado.
} 
"Então você "corpa" algumas coisas, e o artista plástico, o artista visual dá forma àquilo que para ele é desespero". 202

Novamente, Frange traz a referência ao corpo. A um processo de enfrentamento daquilo que provoca um excedente que não pode ser contido. $\mathrm{Na}$ narrativa da artista o corpo é a expressão da subjetividade em termos de produção. Guattari afirma que a "única finalidade aceitável das atividades humanas é a produção de uma subjetividade que enriqueça de modo contínuo sua relação com o mundo". ${ }^{203}$ Nesse sentido, não há, como pode parecer na concepção de Frange, uma subjetividade como recipiente, mas a ideia de um modo de existência, que assume a circulação das coisas do mundo como fontes de energia. São formas de relação que não podem ser contidas, são agenciamentos de enunciação. Processos de subjetivação e semiotização que, que no processo de criação tornam possível a produção de sentidos. É aquilo que escapa a uma imensa "máquina produtiva de uma subjetividade industrializada e nivelada em escala mundial, que tornou-se dado de base na formação da força coletiva de trabalho e da força de controle social coletivo"204. Esses aspectos tornam-se mais claros quando a artista afirma que

[...] as pessoas que optam pela criação... às vezes dizem que é uma válvula de escape, o que não é, mas é uma coisa de sustentação. De sustentar a vida, ou o vivo em nós. Eu só sustento o vivo em mim porque eu crio com imagens e com palavras, cada vez mais. Vou fazer oficina de escrita todo semestre, tenho grupos, porque se não, não consigo viver. $[\ldots]^{205}$

A artista Lygia Clark, em sua carta a Mario Pedrosa, explicita aquilo a que se reporta Frange:

[...] quantos seres sou eu para buscar sempre do outro ser que me habita as realidades das contradições? Quantas alegrias e dores meu corpo se abrindo como uma gigantesca couve-flor ofereceu ao outro ser que está secreto dentro de meu eu? Dentro de minha barriga mora um pássaro, dentro do meu peito, um leão. Este passeia pra lá e pra cá incessantemente. A ave grasna, esperneia e é sacrificada. O ovo continua a envolvê-la, como mortalha, mas já é o começo do outro

\footnotetext{
202 FRANGE, L.B. Ibidem, 2016.

${ }^{203}$ GUATTARI, F.; ROLNIK, S. Micropolítica: Cartografias do Desejo. Petrópolis: Vozes, 1999. p.33.

204 Idem, p. 39.

205 FRANGE, L.B. Ibidem, 2016.
} 
pássaro que nasce imediatamente após a morte. Nem chega a haver intervalo. É o festim da vida e da morte entrelaçadas ${ }^{206}$.

Para Frange, Lygia Clark ...

[...] não separa nem a ética da estética e da política, isso tudo considerado como invenção. Tanto na arte, quanto na clínica. Essa potência inventiva de você fabricar o vivo pulsátil em você é do campo da clínica, igual ao do campo da arte. É igual e eu acho legal esse pensamento. $[\ldots]^{207}$

A radicalização da proposta de Lygia, a processualidade que acompanha seu processo de criação, na arte e na vida, sem que se definam linhas rígidas que separam os saberes e os fazeres, indica uma posição fronteiriça, um lugar no qual Frange vem, cada vez mais, se colocando por meio de suas práticas e reflexões. Em que pese as denominações e enquadramentos "artista, pesquisadora e educadora", as dimensões se fundem, dando margem para um estado de arte, o que implica na criação fundamento para estar e ser no mundo.

Mesmo que, do ponto de vista formal, diga-se social, possa-se tratar nas ocupações, as dimensões ética, estética e política, devem ser indissociáveis, na vida e na arte. Terminologicamente, estas dimensões podem estar separadas,

[...] mas nós não temos feito com que elas atuem juntas. Por isso acho que acho que é preciso que a dimensões ética deve estar junto estética e poética, porque não estamos dando corpo para essa dimensão ${ }^{208}$.

Além do narcisismo mercadológico, que está relacionado a uma compreensão de arte como objeto, a aquilo que é consumido pelo expectador, Frange pensa a arte e a prática artística, amalgamando as referidas dimensões, procurando a "ruptura na ordem do que é visível, pensável, realizável, o universo do possível"209.

Em sua prática experiencia a "partilha do sensível"210, a constituição estética que dá forma à comunidade por meio da experiência com o fazer artístico (Figuras 53 e 54). Percebe-se isso, por meio de seu trabalho com as ...

\footnotetext{
206 Lygia Clark, carta a Mário Pedrosa, 1967; in Sonia Lins, Artes, 1996.

207 FRANGE, L.B. Ibidem, 2016.

208 FRANGE, L.B. Ibidem, 2016.

${ }^{209}$ RANCIĖRE, Jacques. Entrevista. Associação entre arte e política segundo o filósofo Jacques Rancière. Gabliela Longman e Diego Viana. In: Revista Cult. Ed, 139, 2012. s/p.

${ }^{210}$ RANCIĖRE, Jaques, 2009.
} 
[...] rendeiras da llha de Maré... o que elas fazem com as rendas é maravilhoso. Elas fizeram um almoço para nós que era uma renda, era lindo, para nos oferecer. Nós fomos lá fazer o que? Conviver com elas... mostrar para elas... nós encomendamos, compramos e pagamos as rendas delas. Fizemos trabalho que eram no corpo, com as rendas e fomos lá mostrar para elas o que tínhamos feito com as suas rendas ${ }^{211}$. O que eu fiz doei, deixei com elas disse que não era mais meu, mas delas. Era uma cabeça, uma forma de plástico de cobrir bolo cheia de rendas e coisas penduradas, que virou uma cabeça, mas que na verdade era uma celebração de uma entidade. Estávamos na Bahia! E ao mesmo tempo uma coisa de panóptico, de entre linhas. Aí eu achei que isso deveria ficar na mão delas. Como elas fizeram a renda eu dei para elas, ficou lá ${ }^{212}$
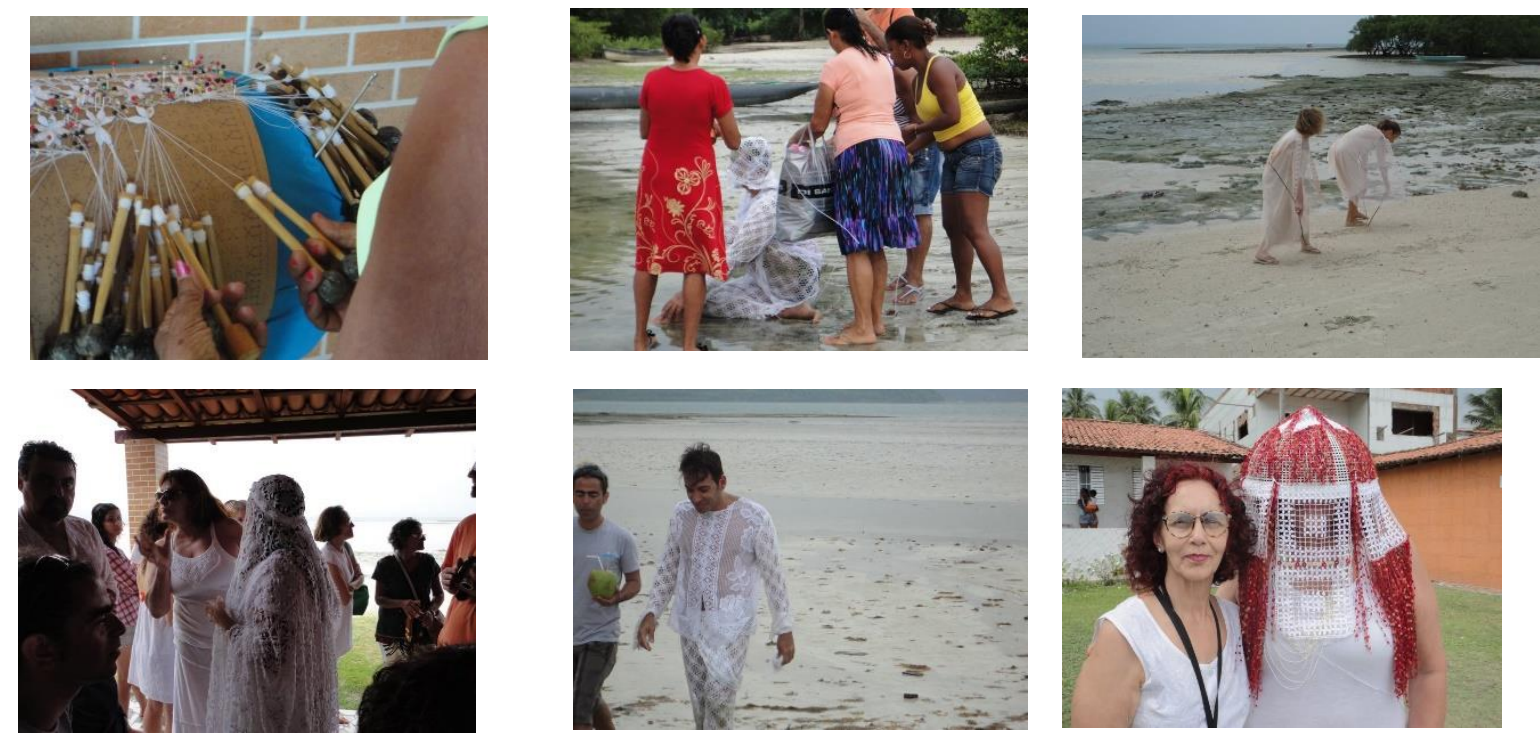

Figura 53. Experimentações coletivas. Travess.ias. Uma pesquisa, 3 expedições. A pesquisa consiste em um trabalho realizado junto a 3 comunidades no interior da Bahia, inter-relacionando processos de criação. Nas imagens estão presentes as artistas e educadoras Viga Gordilho - UFBA, Didonet Thomaz, professor Hugo Fortes - USP e a performance Sissi Fonseca, 2010. Fonte: Acervo da artista.

211 Desenhos de comer, cerâmicas para viver, foi uma ação coletiva realizada pelo Grupo de Pesquisa MAMETO, MAtéria, MEmória, conceiTO, coordenado por Viga Gordilho, em Coqueiros no Recôncavo Bahiano, 28 de outubro de 2010.

${ }^{212}$ FRANGE, L.B. Lucimar Bello Frange: entrevistas realizadas em 2016. Entrevistador: Carlos W. M. de Souza, meio digital de gravação, 2016. 

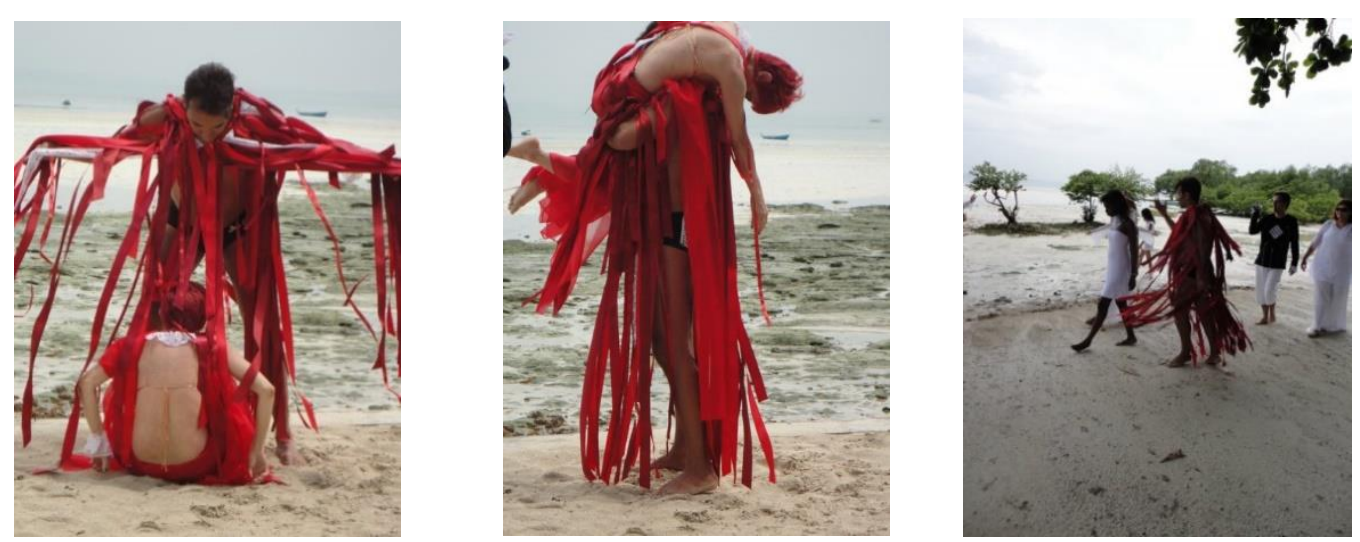

Figura 54. Experimentações coletivas. Travess.ias. Uma pesquisa, 3 expedições. A pesquisa consiste em um trabalho realizado junto a 3 comunidades no interior da Bahia, inter-relacionando processos de criação. Nas imagens estão presentes as artistas e educadoras Viga Gordilho - UFBA, Didonet Thomaz, professor Hugo Fortes - USP e a performer Sissi Fonseca, 2010.

Este envolvimento arte e comunidade, nasce das coisas mínimas, da ativação dos processos na permuta de saberes locais em processos de criação. Nos três locais onde compartilhou e "compartrilhou" os saberes, Cachoeira, llha de Itaparica e llha de Maré, as águas, os sujeitos tornaram-se cúmplices (Figura 55). As "fôrmas" se desfazem "para que tudo na realidade seja processo"213, para que tudo promova o desassossego que ...

[...] vai além da materialidade, mas é a fatura, como você vai construindo sua fatura ao longo de seu percurso de artista, conceitual, verbal, matérica, fatura, o ato de fazer, o que vai virando coisas, coisas no mundo $[\ldots]^{214}$

${ }^{213}$ Carta a Hélio Oiticica, de 26/10/1968, in Lygia Clark e Hélio Oiticica. Funarte, Rio de Janeiro, 1987.

${ }^{214}$ FRANGE, L.B. Lucimar Bello Frange: entrevistas realizadas em 2016. Entrevistador: Carlos W. M. de Souza, meio digital de gravação, 2016. 

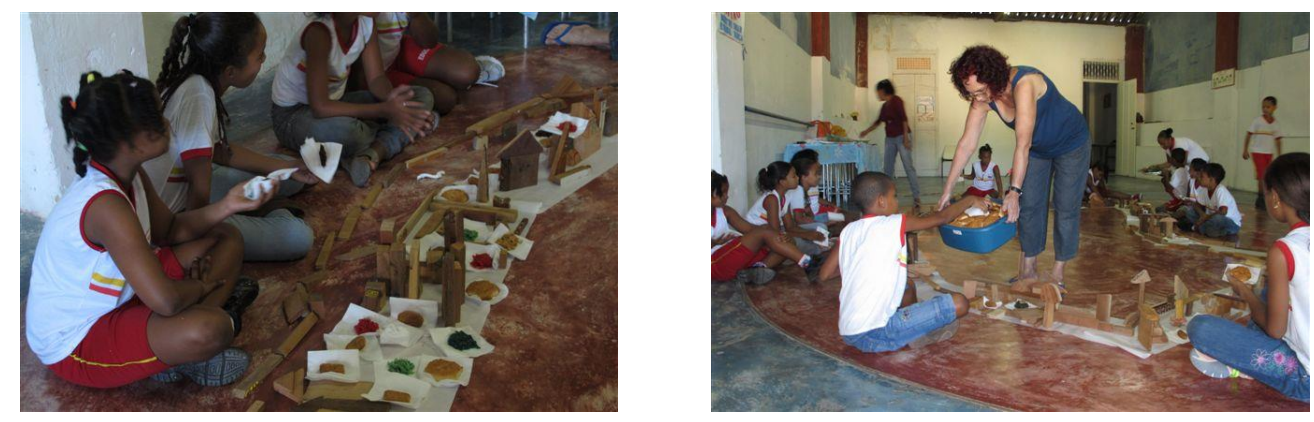

Figura 55. Desenhos de Comer, para Itaparica 2011. Fonte: Acervo da artista.

A interação entre criatura e ambiente, fundamentando o argumento de Dewey sobre lógica ${ }^{215}$, é a condição inicial para o desenvolvimento da experiência. No processo criativo de Frange, a experiência, tanto do ponto de vista de sua atividade como artista, como de educadora, não parece ter um sentido inaugural ou final, ela se ordena e se consuma por meio da relação, que ativa um conjunto de experiências pregressas, familiares, pessoais e impessoais nas quais ...

[...] o objeto aponta para algumas categorias e cria possibilidade de categorias inexistentes, porque cada objeto tem uma relação diversa com a pessoa e com o mundo ... então, nesse terreno movediço que eu resolvi ficar, para fazer meu trabalho e para pensar a arte. ${ }^{216}$

O valor em operação nas práticas artísticas de Frange tem uma natureza distinta que não busca a identificação de um conteúdo para the atribuir significado. Se assim o fosse, haveria um a priori. O que se revela são valores de encontros, de uma cultura do perder-se em que há um constante embate entre o(s) corpo(s) do/e no mundo e seus objetos. Este não é, de maneira alguma, um processo aleatório.

Pode se afirmar que, à medida que o ambiente impõe resistência ou aceitação ao artista, a percepção, o jogo de sensações é transformado em algo que possui objetivo. É no fluxo deste movimento que a experiência se reveste

${ }^{215}$ DEWEY, John. Lógica: a teoria da investigação. In: Os pensadores. São Paulo: Abril Cultural, 1980.

${ }^{216}$ FRANGE, L.B. Ibidem, 2016. 
de sentido: que “(...) encontra muitas coisas no seu desenvolvimento que a deflete e opõe. No processo de converter esses obstáculos e condições neutras em agências, a criatura torna-se ciente das intenções implícitas na sua impulsão"217. Isso é perceptível em sua exposição em Juazeiro do Norte, quando opta por ...

[...] editar línguas de céu, ... lá em Juazeiro do Norte eu montei no chão, como se fosse uns dominós e coloquei vidro em cima, não tem moldura, eu pensei que as pessoas poderiam andar em cima, mas quando eu cheguei lá vi muitas pessoas andando de chinelas Havaianas, fiquei com medo que elas se machucassem no vidro, em função disso eu montei de um jeito que as pessoas poderiam andar entorno ... mas o lugar mais bonito que eu montei o céu foi o chão. Esse processo ajuda a situar meu pensamento, é muito menos objetos no mundo e mais objetos que sirvam para discutir as nossas versões de mundo. ${ }^{218}$

A relação poética com o espaço, que não é somente um lugar de criação, também é "um "socius, que instaura um lugar dentro de outro"219 e inaugura alteridades em seu trabalho, torna-se um fundamento. O espaço surge em sua dimensão social e de democratização de saberes estéticos. Em que pese a criação artística ser um território íntimo, torna-se por necessidade vital, pela pulsão orgânica, necessário que a artista compreenda os aspectos daquilo que faz, o que torna visível e partilhado. Há uma dinâmica em que é preciso se desterritorializar e constituir, em movimento, um novo território a partir de uma distância (Figura 56).

217 DEWEY, John. 2010, p. 61.

218 FRANGE, L.B. Ibidem, 2016.

219 FRANÇA, Cláudia. "SamPer como produção inter-subjetiva". Uberlândia, 2007. Fonte: Site da artista. lucimarbello.com.br. 

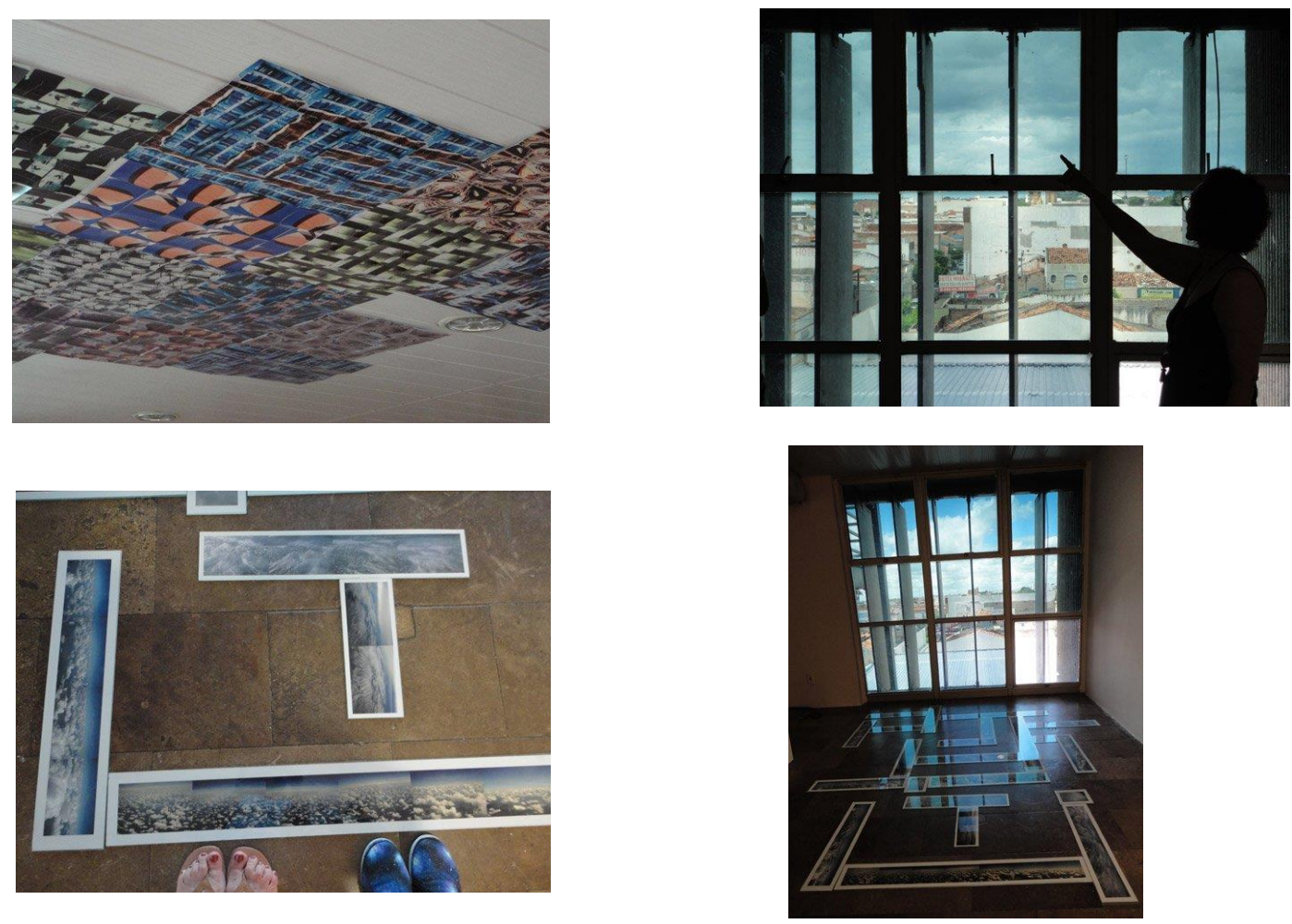

Figura 56. Lucimar Bello Frange: Exposição "Linhas, a cidade lentamente. CCBN, Juazeiro do Norte, 2014. Fonte: Acervo da artista.

Na concepção deleuziana, o que era um espaço indefinido, sem pontos e trajetórias pré-determinadas, é evocado por uma imagística zen, em que "toda flecha já não vai de um ponto a outro, mas será recolhida num ponto qualquer, para ser relançada a um ponto qualquer, e tende a permutar com o atirador e 0 alvo"220. A imagem poética é de uma paisagem em movimento, na qual a ação se desdobra nas fronteiras. Atirador/artista, alvo/público/cúmplices e linguagem se deslocam incessantemente em um processo de desterritorialização de um plano a outro, em que as inserções mútuas são imprescindíveis. Esse deslocamento é evidenciado quando a artista afirma que

[...] Essa coisa complicada que eu criei, para expor eu tenho que conhecer o lugar, eu tenho que visitar o lugar e tenho que fazer uma oficina no lugar, nem que seja no dia seguinte da exposição [...] tenho dificuldade enorme de conseguir aprovar alguns projetos ... as instituições não querem financiar exposições que vão se fazer no processo [...] no meu pensamento, a exposição tem um trabalho meu e vai se completando com o trabalho das pessoas a partir da minha imersão com essas pessoas [... $]^{221}$

220 DELEUZE, Gilles; GUATTARI, Félix. Mil platôs: capitalismo e esquizofrenia. Trad. Ana Lúcia de Oliveira e Lúcia Cláudia Leão. Rio de Janeiro: 34, 1995. p.47.

${ }^{221}$ FRANGE, L.B. Ibidem, 2016. 
Depreende-se que o outro, o lugar e o tempo do outro, são linhas de fuga pelas quais a dessubjetivação acontece. São um modo de colheita que alimenta as trocas e dão sentido às imagens. Sua prática envolve agenciamentos, mas também os campos da institucionalidade, o que remete ao lugar da arte e da criação nos contextos sociais. Todavia, quando esse processo colide com as normas, com o engessamento institucional, o próprio processo de criação sofre interferências.

As instituições, isso inclui as educacionais, ainda mantêm a imagem clássica do artista, confinado ao seu atelier, que depois de um "processo mágico" revela ao mundo sua obra. Trata-se, pois, de duas relações distintas e complementares. De um lado, os agenciamentos estéticos criam uma relação em que a marca do outro é fixada no próprio processo criativo. De outro, os corpos sociais, técnicos e políticos são mediadores que impõem limites aos desejos da criação e da produção da subjetividade. Quando esses nós são desfeitos, a experiência se efetiva, com no ...

[...] trabalho em Itaparica. Eu consegui voltar lá 2 anos depois e entregar para cada pessoa que participou do projeto um postal ... a alegria que elas me deram pela forma que receberam esse ato simples, simbólico, é o que alimenta o trabalho. Eu não quero usar a comunidade, nem servi-la, é produzir com ela. 222

Nas experimentações coletivas, Frange vem mostrando que a potência da arte, das experiências estéticas aciona uma abertura inventiva, mobiliza os processos de produção de sentidos e opera processos de transformação social. A relação com a materialidade do mundo, nessa dinâmica, é bastante complexa. São vetores múltiplos: políticos, culturais, tecnológicos, ecológicos que definem as escolhas. Indaga a si mesma acerca de "[...] para que juntar garrafas pet, 0 que vai fazer com elas e que relação elas têm com sua estrutura de pensamento" 223

Seria óbvio afirmar que materialidade é o ato de tornar a ideia perceptível para o outro, sendo que, matéria nas artes é tudo aquilo que pode ser utilizado 
para dar forma. Mas há um problema nessa afirmativa. Quando se fala em matéria na arte, logicamente, pensando na produção contemporânea, fala-se de qualquer coisa, inclusive o corpo como suporte da expressão. Mas ainda assim, isso parece óbvio. Não obstante, as reflexões pretéritas sobre as transformações perceptuais e a apropriação de distintos materiais, a partir do início do século $\mathrm{XX}$, Frange adiciona um problema sobre as práticas artísticas que deve ser abordado: a maneira como a matéria se relaciona com a estrutura de pensamentos do artista. Não se trata de abordar questões relativas à chamada arte conceitual e abrir as dicotomias entre a materialidade da consciência e a consciência da materialidade. Mas sim, de compreender um processo em que a imaginação confere outras funções aos objetos até que fiquem à disposição de ser uma outra coisa. A escolha, a guarda, as notas de percursos e ideias, a transmutação e a maneira como se coloca em circulação, definem a abertura semântica que torna algo ativador das experiências.

Há uma "desutilidade" poética que "desinventa", as coisas do mundo e promove o dissenso da percepção. Uma poética que busca o originário, subverte a linguagem e "descoisifica" a realidade. Ao refletir sobre seu próprio trabalho, outros artistas remetem à mesma problemática, como se vê:

[...]eu penso meu trabalho nessa questão. Proponho uma figura estética que crie um consenso coletivo, mas como cada um pensa ou sente esse objeto estético cria um dissenso imediato, e isso me interessa na proposta de trabalho e aí que surge a comunicação.

Eu estou trabalhando uma imagem que é reconhecível praticamente no mundo inteiro, talvez uma tribo ou outra não reconheça esse objeto, quando eu exponho dentro ou fora do Brasil as pessoas reconhecem rapidamente e sabem como funciona aquilo e sabem que é um objeto feito para encaixar na mão, então tem ali um apelo estético muito forte. As pessoas sendo a favor ou contra elas querem pegar e tem esse fetiche. Isso me interessa, criar um fetiche coletivo dentro do trabalho. Aquilo parece um brinquedo, parece que tem potencial de violência. As pessoas têm esse prazer e esse fetiche por esse objeto. Então, como questão estética isso é extremamente importante no meu trabalho. ${ }^{224}$

Não se trata de colocar objetos no mundo, como afirma Frange, discorrendo sobre o processo que deu origem à exposição "Carta Cura Corte", tratada na leitura de sua trajetória.

${ }^{224}$ Fragmento da entrevista concedida pela artista educadora AE4, em 2016, a Carlos W.M. de Souza. 
[...] eu fiz 30 vídeos e mandei para cada um com uma carta e o nome deles na lombada! [...] 30 cartas para Hélio e Lygia e aqui eu pus o nome da pessoa (mostrando a capa) ... eram numeradas 1 de 30, 2 de 30 e assim vai, 30 pessoas que responderam e mandei um videozinho, como são 30 cartas eu imprimi e pus para cada um uma carta e uma fotinha (aqui eu chamei de a "pilha de peles âmbolas") e cada um recebeu um, eu não tenho nenhuma ...eu mandei para as pessoas, elas têm, eu não tenho, se algum dia elas quiserem juntar e fazer algo com as cartas, está na mão delas. Uma certa autonomia de fazer isso, eu acompanhei pelo correio e sei que cada um recebeu. Algumas pessoas me perguntam, aí o trabalho acabou? Não, o trabalho está 1/30 com cada um dos 30 ... ele esparrama, ele vai para o mundo, meu trabalho não é de colocar objeto no mundo, eu não estou muito preocupada com essa dinâmica. Depois que eu recebi os e-mails eu mandei um e-mail contando para eles o que eu fiz, os vídeos e que eu já tinha feito uma exposição em Goiânia ... assim, tem ciclos, um trabalho vai engendrando no outro $[\ldots]^{25}$

Para o poeta francês Pierre Reverdy a "ética é a estética de dentro"226. A maneira como Frange pensa seu processo criativo, o fazer junto, a alteridade que brota das relações com o estético exige essa indissociabilidade. $O$ ethos, ou seja, o modo de ser, o caráter é inerente à ação que produz a imagem. Não se trata de uma "consciência moral" que está condicionada às regras, mas da constante avaliação e julgamento sobre a coerência das ações estéticas e das responsabilidades ali contidas. É uma relação de equilíbrio entre princípios e condutas, que parece ter se diluído em tempos que "os fins justificam os meios".

Em uma entrevista concedida em 1984, Michel Foucault dizia que a ideia de uma moral como obediência a um código de regras estava desaparecendo. Em seu lugar deveria surgir a busca de uma "estética da existência"227 que visa a construção de uma subjetividade ética, transformando a vida em uma "obra de arte pessoal"228. Esta talvez seja a melhor definição para a maneira como Frange trabalha com a arte, com o outro e na vida.

Esse modo de existência intensifica os modos de alteridade, como no trabalho "Carta cura corte" em que ...

[...] 30 pessoas me responderam as cartas, eles são autores do trabalho, eu só transcrevi, montei, fiz variações dos 30 presentes que eu recebi ...eticamente eu tinha que devolver para cada pessoa alguma coisa, porque o que eles me deram tem rendido tanta coisa até hoje, que ... é muito potente o que me deram. As pessoas toparam entrar no trabalho, elas são cúmplices ... o menino que fez o vídeo perguntou se

225 FRANGE, L.B. Ibidem, 2016.

${ }^{226}$ REVERDY, Pierre. 1889-1960. s/p.

${ }^{227}$ FOUCAULT. Michel. A hermenêutica do sujeito. 2004. São Paulo: Martins Fontes. p. 290.

228 Idem. p. 290. 
eu não queria um para mim ... não eu não posso, eu não escrevi, eu tenho fotos $[\ldots]^{29}$

Não é a arte que está em questão, mas um elo que foi desconstituído entre ela e a beleza, concedendo "ao leigo, o direito de produzir esteticamente"230. O que essas práticas revelam é a possibilidade de qualquer pessoa de interferir em nível simbólico, redefinindo as maneiras de compreender e abordar a realidade. São faturas, que envolvem a dimensão coletiva da subjetividade e incluem coisas, artefatos e a própria relação consigo.

[...] O Dudi (Maia Rosa) dizia que eu sou muito obsessiva ... os 110 desenhos que eu fiquei 110 dias seguidos marcando um gesto, não quero mostrar separados, não quero vender nenhum ... as pessoas viam separados e queriam comprar - Me vende 5, eu não vendo! ... são 110, se quiser comprar 110 pode comprar, se não quiser, eu não vendo nenhum. Depois eu mostrei uma vez, no Pará, 139 desenhos, mostrei 139, só mostrei uma vez, os 110 não mostrei nenhuma, se algum dia tiver um lugar eles vão para o mundo, se não, eles vão ficar morando na caixinha .. algumas pessoas ... ah eu quero comprar alguns, - não vendo, só vendo tudo! O prazer que esse trabalho me deu quando eu vou para algum lugar e tem um encontro, é mais do que vender! São camadas ... é uma forma de fatura do próprio trabalho .......] Eu fiz o trabalho e não tenho mais, não é meu, está no mundo [...] os lugares que acolhem são os que não são oficiais, mercadológicos da arte, são estes lugares [... $]^{231}$

Como é possível perceber, a prática artística é pensada por Frange como uma fatura, como sua identificação com uma potência própria do pensamento, com um modo específico de presença do pensamento na matéria que é também heteronomia do pensamento. É a expressão de um corpo semântico que se apropria dos aspectos técnicos e formais de uma arte pretérita que é indispensável, não como uma norma de conduta, mas como um saber poético. $E$, a partir das questões que lhes são intervenientes nos modos de existir e estar com o outro, nessa zona de indeterminação, confere sentidos a cada intensidade das camadas que compõem o seu trabalho.

A ideia foucaultiana de uma estética da existência, para Deleuze é uma forma de estabelecer uma relação de força consigo, uma dobra que "permite

${ }^{229}$ FRANGE, L.B. Ibidem, 2016.

230 DE DUVE, T. Kant depois de Duchamp. Revista do Mestrado em História da Arte, Rio de Janeiro, v. 5, p.144, jul. - dez. 1998.

${ }^{231}$ FRANGE, L.B. Ibidem, 2016. 
resistir, furtar-nos, fazer a vida ou a morte voltar-se contra o poder"232. Não são formas determinadas ou coercitivas, mas regras facultativas que permitem a invenção de novas possibilidades. Assim fluem as práticas estéticas de Frange, em dobras nas quais

[...] tem uns modos de trabalhar, primeiro você tem que catar fragmentos do mundo, depois você tem que agregar isso e depois fazer isso circular ... isso tudo tem que ter uma coerência, não pode ser um objeto qualquer, o jeito de agregar, não é qualquer jeito, tem que ter uma escuta desse objeto, eles pedem como querem ser agregados, isso demora! Dá uma angústia desesperada, porque leva um tempo ... Eu estava olhando aí, não sei quantas fotografias do céu eu tenho, agora eu vou achando, de muitos anos, muitos anos, de muitas viagens, até que isso começou a virar trabalho, eu achei um pendrive aqui, essa coisa de céu, quase todo mundo tem, porque é fascinante, ... essa coisa de fazer tiras de céu ... tem essa dinâmica, e, a circulação só acontece quando tem relação com as pessoas. É sofrido demais, porque tem vezes que você "nada nada nada e chega na praia e vê que não dá e volta para trás". Para mim, se não tiver a relação de cumplicidade, não interessa! ${ }^{233}$

[...] às vezes eu fico desesperada porque sinto que não estou trabalhando e me pergunto, cadê minha capacidade criadora, de repente eu consigo ver a liga das coisas, enxergar a possibilidade de um trabalho. É um mergulho cada vez mais fundo, quando você não consegue mais você vai a superfície para respirar e nisso vai um lampejo, pode ser por aqui, aí você mergulha de novo, assim vão dias, anos. $^{234}$

São "partilhas do sensível", nas quais as formas de individuação pretéritas se desfazem, em que a matéria e o espírito se desorganizam, o mundo se abre e o pensamento encontra um lugar em que os objetos que contempla assumem a condição de cúmplice de um desenho emancipado, em que o

[...] o pensamento, a atitude é de Linha no Mundo ... é desenho. Agora, se a linha é larga, se ela é de metal ou de borracha, não importa, é uma linha, uma intersecção mínima no mundo. [...] hoje eu já acho que vou ser sempre estrangeira, até de mim mesma, é uma atitude de não querer ficar aportada ... é mais do que não parar quieta, é estar pulsando permanentemente, é um pulso que você está sempre bem, porque você é estrangeiro de si mesma. ${ }^{235}$

232 DELEUZE, G. Conversações (1972-1990). São Paulo: Editora 34, 1992, (Coleção Trans). p. 123.

${ }^{233}$ FRANGE, L.B. Ibidem, 2016.

${ }^{234}$ FRANGE, L.B. Ibidem, 2016.

${ }^{235}$ FRANGE, L.B. Lucimar Bello Frange: entrevistas realizadas em 2016. Entrevistador: Carlos

W. M. de Souza, meio digital de gravação, 2016. 


\title{
3.2.2 A experiência da e com a imagem na perspectiva de Lucimar Bello
}

\begin{abstract}
Defender com letras aquilo que não é feito com letras. Agora, eu ainda tinha feito com letras, eu fiz verbetes desenhados, a palavra estava lá para ser escrita...

Eu ainda não consegui dar o recado de que as artes visuais são mais imagens, a entrada é pela imagem. O verbal vem junto, o conceito vem junto. Não existe imagem sem conceito, não existe imagem sem palavra, não existe imagem sem pensamento. Não existe! Não é você pensar e depois fazer a imagem. Não é assim, é junto. As pessoas entenderam como ilustração e não entrou. ${ }^{236}$
\end{abstract}

A narrativa de Frange expressa o descontentamento sobre um momento em que o seu trabalho não foi devidamente compreendido em um congresso de arte educadores. Essa situação permite trazer alguns problemas muito relevantes para que se possa pensar sobre o conceito de imagem nas práticas artísticas contemporâneas e, posteriormente, seu trato no campo educacional.

Como é possível perceber, Frange apresenta, de uma só vez, duas questões. A primeira refere-se à uma espécie de subordinação da imagem à palavra, a segunda está relacionada aos processos que envolvem o pensamento e a prática. São questões que se fazem presentes na epistemologia, nas teorias do conhecimento e são indissociáveis. Dessa forma, torna-se necessário tratálas do ponto de vista filosófico.

Entende-se que a origem desses problemas esteja no valor atribuído pelo pensamento kantiano às belas artes. $\mathrm{O}$ autor, que assumiu vital importância para a compreensão da racionalidade moderna e seus rebatimentos no pensamento sobre arte e educação, trouxe a poesia para um lugar de destaque em função de sua capacidade relacional com o mundo do entendimento racional. Ao afirmar que

[...] entre todas as artes a poesia (que deve sua origem quase totalmente ao gênio e é a que menos quer ser guiada por prescrição ou exemplos) ocupa a posição mais elevada. Ela alarga o ânimo pelo fato de ele por em liberdade a faculdade da imaginação e de oferecer dentro dos limites de um conceito dado sob a multiplicidade ilimitada de formas possíveis com ele, aquela que conecta a sua apresentação uma profusão de pensamentos [...] Ela joga a aparência que ela produz à vontade, sem contudo enganar através disso; pois ela declara a sua

${ }^{236}$ FRANGE, L.B. Ibidem, 2016. 
própria ocupação como simples jogo, que, no entanto pode ser utilizado conformemente a fins do entendimento ${ }^{237}$.

Kant sedimenta a base para separar a filosofia do encargo da metafísica, em especial da explicação dos elementos de transcendência. Ao mesmo tempo, à arte foi atribuída uma condição de espiritualidade, sendo que o gênio, o artista comunica essa transcendência na obra de arte bela. Essa transcendência não pode ser conhecida ou definida pelo conceito aplicado na experiência empírica e se traduz numa relação livre entre imaginação e razão. Dessa forma, nos contornos que envolvem as faculdades humanas, em que a imaginação e a capacidade racional, em acordo, oferecem a possibilidade à experiência, não caberia uma relação positiva entre as faculdades sensíveis e a razão para o processo do conhecimento.

Esta compartimentação promovida pelo pensamento de Kant encontra sua antítese na filosofia pragmática de Dewey, que faz uma veemente crítica ao surgimento da concepção compartimentada das chamadas belas artes, opõe-se à ideia de uma experiência estética e intelectual separadas na construção do conhecimento e destaca os efeitos nocivos dessa compreensão no distanciamento entre a vida cotidiana e a arte. O que está implícito nesse embate não é apenas a hierarquização da linguagem, mas o desdobramento na oficialização e incorporação dos valores da "alta cultura" que passa a consagrar a imagem na arte, como algo relacionado ao objeto que representa nos acervos dos museus, um gosto requintado que faz alusão à uma espécie de "cultura especial" 238 .

O que as práticas artísticas contemporâneas apresentam é uma ruptura com essa institucionalização, com as hierarquias e com o próprio conceito de imagem. Um processo no qual as diferentes formas de inscrição atuantes no processo de criação artística trazem a presença da escrita como conceito e matéria. Sobre isso, a artista AE2, acrescenta:

[...] Penso que, embora seja amplo e admita diversas acepções, enfrentar a imagem e sua pluralidade é uma questão importante para o artista, para o pesquisador e para o docente. Em termos gerais, creio que a imagem faz parte de uma relação dinâmica com o referente,

\footnotetext{
${ }^{237}$ KANT, Immanuel. Crítica da Faculdade do Juízo p. 171.

238 DEWEY, John. Como pensamos: como se relaciona o pensamento reflexivo com o processo educativo. 3. Ed. São Paulo: Cia Editora Nacional, 1979.
} 
vamos chamar isso de real. O sujeito, seu contexto e sua intencionalidade, esse complexo, construirá ou será construído por uma relação com o real, o que determina tipos e tipos de imagem. Elas podem ser artísticas ou não, e se esse sujeito for um artista, imagens poderão desembocar em imagens artísticas. De qualquer modo, construirá linguagem com essas relações que estabelece com o real. A discussão, talvez uma das mais correntes, refere-se à inflação de imagens que vivemos; nossa saturação que nos impede de ver. ${ }^{239}$

A ruptura com a autonomia da escrita no campo das artes visuais reporta aos anos de 1950/60. Nesse período, inúmeros trabalhos, expostos por artistas como Joseph Kosuth, Lawrence Weiner, Dan Graham, eram apresentados por meio de registros textuais, datilografados, impressos e mesmo manuscritos, a palavra escrita aparecia como materialização da linguagem e veículo de ideações do artista em seu exercício conceitual.

Nesse sentido, para que se possa compreender a amplitude da imagem no contemporâneo, faz-se necessário, levar em conta não apenas o aspecto "formal e compositivo, mas as questões relacionadas a valores humanos e sociais, os contextos históricos e culturais" 240 em que esta hibridação acontece. Hoje, como afirma Frange

[...]as artes visuais, que nós chamamos hoje, que não chamamos mais de artes plásticas, que ficamos tentando ampliar, não dá para trabalhar sem a literatura, não dá para trabalhar sem história, não dá para viver sem esses nexos. Não dá para viver, quanto mais para produzir. ${ }^{241}$

[...] Sobre o meu trabalho no salão de arte na Bahia. Quando receberam esse projeto que acabou se chamando Intermediações, eles já tinham feito a seleção dos artistas, mas o salão não estava montado. Eles me chamaram para ver os projetos dos artistas junto com os arte/educadores. E a gente foi pensar um programa de ação educativa a partir dos projetos dos artistas, antes de montar o salão. Fiquei lá, trabalhamos uns dias com os projetos na mão. E é isso que eu falava, qual era o pensamento dos artistas quando faziam um projeto para mandar para um salão? O edital pedia um projeto, não pedia apenas as obras. Depois com o salão montado fui trabalhar com eles uma segunda vez. Depois quando o salão estava no fim, fui trabalhar uma terceira vez com eles. Nós gestamos, no grupo, um modo de trabalhar para aquela experiência. Eu nunca tinha participado

${ }^{239}$ Fragmento da entrevista concedida pela artista educadora AE2, em 2016, a Carlos W.M. de Souza.

${ }^{240}$ RIZZI. Maria Christina de Souza Lima. ANJOS, Ana Cristina Chagas. Arte-educação e meio ambiente: apontamentos conceituais a partir de uma experiencia de arte-educação ambiental 2010, p. 31.

${ }^{241}$ FRANGE, L.B. Ibidem, 2016. 
de uma ação, em que você tivesse o trabalho do artista antes da exposição. Nem o projeto. ${ }^{242}$

Como é possível perceber, na concepção de Frange a forma/imagem não surge como sinônimo de um objeto. É um modo de operar, um conjunto de processos nos quais o objeto de sua investigação/percepção, se conecta ao conjunto de toda experiência. A investigação intelectual e as referências imagéticas não têm, nos processos de Frange, uma ordem fixa ou hierarquizada. As fontes de produção da imagem partem do princípio de que toda arte também "[...] é conceitual"

Em função disso tem como fonte os aspectos filosóficos da existência humana.

[...] Em uma especialização em Filosofia, nos anos 90, eu me propus a uma reflexão, embrionária ainda, primária, sobre a Crítica do Juízo de Kant. Eu propunha pensar sobre a criação desse campo que hoje nós chamamos de subjetividade nesse ponto, não, ele não fala isso, mas ele cria uma fissura na teoria que te permite pensar sobre isto ${ }^{243}$.

A politicidade das imagens está relacionada a um regime de articulações de seus elementos e funções. Memórias, referências, narrativas, são ordenadas na possibilidade para novos modos de ver e sentir. Nesse processo o estar junto não comporta apenas o outro físico, mas o outro pensamento, o outro criação, as inconsistências do real que mesclam as potências e contradições subjetivas e coletivas.

[...] Nessa perspectiva cronológica, vou tentando puxar na memória de onde vem minhas inconsistências, mais que as consistências ... depois quando você está falando da educadora, quando eu comecei a estudar arte, nos anos 60,70, Duchamp, Fluxus, Ricardo Basbaum. Aonde eu fui me sentir mais confortável, a fonte do Duchamp, ele trouxe as coisas do mundo para dentro da arte ... o Fluxus trazia aquelas intervenções espaciais que hoje chamamos de instalação, e o Ricardo Basbaum que é um artista, filósofo, curador, que faz cartografias de suas produções, sempre na perspectiva da coletividade, do fazer junto ... as escolhas vão por esse caminho [...] o trabalho só se efetiva na relação com os outros [...] uma das coisas é que eu escolho dialogar com as pessoas que tratam desse contraditório, da tensão entre o projetado

242 FRANGE, L.B. Ibidem, 2016.

${ }^{243}$ FRANGE, L.B. Ibidem, 2016. 
sólido e a fragilidade extrema [...] uma tensão de viver o trabalho, você fica na relação de atrito. ${ }^{244}$

Frange conecta ética e estética, apontando que a forma/imagem não se encontra exclusivamente na configuração de um objeto visível. Assim, define com propriedade as chaves para sua compreensão no contemporâneo.

[...] estética são as categorias que estão na filosofia, nas artes, estão ligadas ao belo e ao feio; ética, o que é uma chave (objeto) no mundo hoje, o que é uma chave lá, para que serve, o que é a chave no meu mundo, quem pintou, para quem pintou, como, o que é para mim ... o que são essas chaves? Se eu estou aqui vendo essa chave, com você, e ela foi pintada lá, já tem outra relação, eu com essas coisas é uma coisa, você eu e essas coisas é outra relação, ampliou o campo de pensamento.

[...] (sobre a grande exposição de Lygia Clark) até hoje as pessoas não entenderam, ela não abandonou a arte, ao contrário, ela aprofundou os conceitos da arte ... ela foi trabalhar com o mínimo, mínimo de objetos ... ela foi fazer os objetos relacionais, no campo da invenção, juntou o objeto à vida e ao corpo.

[...] uma frase do Franz Manatta, que é a pessoa que mais conhece meu trabalho hoje, ele me ver que meu trabalho só completa com o outro, não é para ser do outro que o trabalho acontece, na relação, não é dentro da estética relacional, é dentro de uma perspectiva muito mais subjetiva, porque tem compartilha, é compartilhar uma coisa com outra.

[...] se deixa escapar a dimensão ética que está dentro da estética, como a estésica que está dentro da estética, você deixa escapar essas relações, para mim, o trabalho não sustenta, porque não é só invenção na arte, invenção na arte e na vida juntas, para mim tudo é colado.

[...] preciso verbalizar que arte é vida, para as pessoas entenderem que meu trabalho faz parte do meu projeto de vida, preciso verbalizar para marcar esse território...[...] o meu pensamento é de desenho ... venho dessa escola, de transformar as coisas em fragmentos e, ao mesmo tempo, reagrupar, o trabalho demora a ficar pronto, porque eu coleciono, faço milhões de fragmentos para depois fazer um trabalho único. $^{245}$

Nos trechos das entrevistas, a articulação entre o que é da ordem do subjetivo, dos processos, das relações de alteridade, da mobilização das referências, das maneiras de operar, destacam que, tomar a imagem pelo que ela possui de visual, significa desconsiderar o complexo jogo de relações que define o seus sentidos e sua especificidade na esfera social e formativa. A 
imagem por ela mesma, desligada das dimensões supracitadas, a deslocam para fora do universo da integrado, acentuando as oposições que deveriam ser diluídas (imagem/ação; imagem/espaço; imagem/tempo imagem/testemunho; imagem/memória; imagem/pensamento; imagem/processos; imagem/invenção).

\title{
3.2.3 Práticas pedagógicas no trabalho de Lucimar Bello
}

\author{
Aula não é nula \\ aula não é nula \\ aula não é nula \\ aula não é nula ${ }^{246}$
}

\section{Experiência sensorial das palavras}

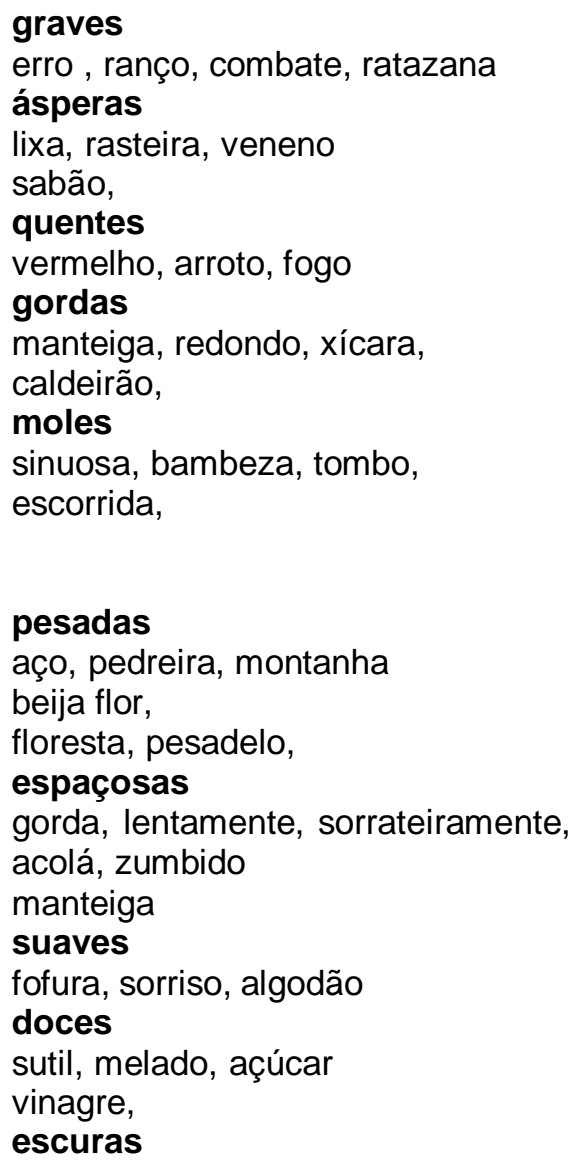

\section{agudas}

alfinete, alívio, altura lisas

escorregão, mambembe,

frias

cinza, geleira, arroz branco, magras

agulha, vertical, coqueiro,

duras

ferradura, atolado, tapa,

\section{leves}

delicadeza, finura, sonho,

espremidas

já, de repente, aí, aqui,

estridentes

fofoca, gargalhadas, agudíssimo ácidas

azedo, emburrado, limão,

claras

246 Poema: aula não é nula. Lucimar Bello Frange, 2013. Disponível em: lucimarbello.com.br. Acessado: 24/10/2015. 
negritude, acanhado, bravura bondade carinho, nuvem, sedoso, ${ }^{247}$

Dewey afirma que "é pelas atividades compartilhadas e pela linguagem e outros meios de interação que as qualidades e valores se tornam comuns na experiência de um grupo da humanidade"248. Se a imagem não é fetichismo, mas o poder contínuo que afeta diretamente o homem, formando registros e marcas na história, para educar e transformar, porque não as tomar em sua diferenciação. Discerni-las da imageria, encontra-las nos muitos modos de operar que a arte propõe, talvez abra um campo de possibilidades ao processo educativo.

Frange tem dificuldade nessa partilha do sensível que "faz ver quem pode tomar parte no comum em função daquilo que faz, do tempo e do espaço em que essa atividade se exerce" 249 . O plano comum sensível e espaciotemporal dos corpos, das narrativas, das práticas e processos, nem sempre estão em sintonia com as aberturas que, no campo pedagógico deveriam refletir novas experiências. Em um dos congressos acadêmicos da Federação de Arte Educadores do Brasil (CONFAEB) reflete sobre as incompreensões ...

\begin{abstract}
Não publicaram os verbetes (breve pausa). Porque acharam que aquilo era um Power Point, e aquilo não era um Power Point, era minha palestra (nova pausa). Eu estava em um congresso de arte-educação e eu sou artista. Deu um enorme trabalho escrever o texto, fazer os verbetes, e eu queria que publicassem os verbetes. Os verbetes eles limparam, porque acharam que aquilo era uma ilustração. Não era uma ilustração, era o corpo do texto. Então assim, quanto mais embate tem, mais eu quero fazer por esse lado. Não é uma performance, mas eu não tenho que ficar falando para todo mundo ficar me ouvindo ${ }^{250}$.
\end{abstract}

Quando Foucault 251 mostrou que as formas de discursos e de sensibilidades se constituíram como dispositivos de produção de corpos submetidos e mentes subservientes, que operavam fabricando subjetividades e corporeidades nas fábricas, escolas e prisões, também mostrou que, em certo

247 Exercício sem palavras. Experiência sensorial das palavras. Lucimar Bello Frange, 2009. Disponível em lucimarbello.com.br. Acessado: 24/11/2015.

248 DEWEY, John. 2010, p. 491.

${ }^{249}$ RANCEIĖRE, Jacques. 2005 p. 16.

${ }^{250}$ FRANGE, L.B. Ibidem, 2016.

${ }^{251}$ FOUCAULT, Michel. Vigiar e punir: nascimento da prisão; Trad. Raquel Ramalhete, Vozes, 1987. 
sentido, tais sujeições poderiam ser combatidas por meio dos regimes de sensibilidade e dos regimes da linguagem. Assim, o conceito de agenciamento torna-se, então, um operador essencial ao ensino da arte. Uma vez que remete ao modo concreto de produção da realidade, nas múltiplas dimensões, material e imaterial.

A ausência dessa perspectiva, pelo distanciamento entre as práticas artísticas e as práticas e reflexões no contexto do ensino da arte brasileiro, talvez tenham sido motivadores do afastamento das discussões sobre o ensino da arte de Frange por um determinado tempo.

\begin{abstract}
Até o dia que eu achasse, como professora de arte, eu poderia falar de um lugar que eu não ficasse ferida. Uma opção, mas eu de uma certa forma. Mas eu fiz uma opção de ficar calada, com uma vontade louca de falar, uma vontade louca de escrever. Escrevia e não publicava, pensava e não dizia. Então, assim, eu criei uma ausência de mim mesma de num certo contexto, que embora lesse, visse, procurasse, mas eu não me manifestava. Era uma atitude de escolha de silêncio para maturar uma situação que era difícil para hora da fala. De uma fala vir com uma força, e não com um chororô e uma (des) potência. Mas uma força de invenção de vida. Foram precisos seis anos de mudez, nesse aspecto. Por outro lado, ao mesmo tempo que eu fiz um certo corte de uma liberdade, e uma certa escolha, eu produzi enlouquecidamente. Mais como artista, menos como arte-educadora. Eu dei um certo tempo de resguardo para o pensamento do que é arte/educação, e dei força para o pensamento de criação nas poéticas. ${ }^{252}$
\end{abstract}

Este intervalo de vida, como afirma a artista, possibilitou que encontrasse a unidade entre as suas práticas artísticas e os modos de operar no processo formativo. Ligar, conectar, conjugar, compor, combinar, produzir, fabricar, passaram a ser formas de agenciamento afirmativos de potência, de uma arte educação para potência.

[...] eu tive consciência, que consegui construir que não sou professora nem arte-educadora, e nem artista. Eu sou tudo junto, pesquisadora, artista, professora, tudo junto. Aí comecei a ver que as minhas aulas de anos atrás, dos anos 90 , já eram desenhos no quadro. ${ }^{253}$

Frange se reporta ao curso que ministrou sobre a abordagem de John Dewey no ensino da arte. _ Curso do qual participamos durante o último ano da graduação. A artista relembra que ...

252 FRANGE, L.B. Ibidem, 2016.

253 FRANGE, L.B. Ibidem, 2016. 
[...] começava a escrever com giz branco, era o pensamento de alguém, aí colocava vermelho que era meu, amarelo que era de outra pessoa, verde de outra, depois aquele quadro era uma zona, mas era uma zona muito organizada. Para os alunos eu não sei até que ponto ficava. Mas eu dizia, isso é pensamento meu, isso é pensamento do outro, já era um desenho dentro do quadro negro, que naquela época era verde. ${ }^{254}$

Mesmo nos processos acadêmicos, nos quais a prevalência do pensamento conceitual dita os modos de compreensão da realidade, é possível que a dimensão poética assuma um lugar de equivalência. Frange, ao distinguir esteticamente, por meio das cores, os modos de pensar dos autores e os seus, traz para o contexto de uma aula teórica, os elementos composicionais do desenho. Ou melhor, do seu modo de pensar a arte, o desenho. Uma conjunção de experiências, uma ação rizomática ${ }^{255}$ que conecta pontos promovendo a heterogeneidade e a amplitude que compõe a complexidade do conhecimento. Palavras, pensamentos, cores são linhas no mundo. São conexões, pontes de comunicação entre os saberes que evidenciam as qualidades de sua abordagem.

\begin{abstract}
Aí comecei a perceber que a.... quando eu falo que o professor, o artista ... é um ator, é nesse sentido, ele é ator de si e ator em relação com os outros. E a mediação só pode acontecer na medida em que você faz com que todas as pessoas que estejam envolvidas, seja os teóricos que você traz, seja os artistas que você traz, seja as imagens que você traz, seja as coletas, as colheitas das pessoas que estão com você naquele momento...quando tudo aquilo junto produz um outro conhecimento, uma outra dúvida, uma outra questão que não é de mais ninguém, mas é gestado ali naquele grupo. Como se você tivesse encenando uma peça. Você vem com um certo enredo, uma certa história, um certo pensamento, mas aí fabrica com todo mundo uma outra peça nova que vai ser encenada ali, naquele momento, no aqui no agora daquele momento. Então, isso que eu estava falando da liberdade, da escolha, da...até uma certa subversão da obediência, da subserviência que eu que está junto também. Obedecem-se algumas coisas para desobedecer às outras, você cria umas formas para conseguir nelas, ou delas, extrair umas formas $[\ldots]^{256}$
\end{abstract}

\footnotetext{
${ }^{254}$ FRANGE, L.B. Ibidem, 2016.

${ }^{255}$ Rizoma é um conceito elaborado por Deleuze e Guattari que define um modelo de resistência ético-estético-político, trata-se de linhas e não de forma. $O$ agenciamento é, nesse sentido, 0 crescimento das dimensões numa multiplicidade que muda de natureza à medida em que aumenta suas conexões. DELEUZE, G. GUATTARI, F. Mil Platôs: capitalismo e esquizofrenia, Vol. I. Rio de Janeiro:34, 1995.
}

${ }^{256}$ FRANGE, L.B. Ibidem, 2016. 
Nessa mesma linha, AE2 acrescenta os elementos subjetivos derivados dos processos concretos relacionados ao ato educacional em arte:

[...] Meu lado professora de Desenho quer ensinar ao aluno o prazer de se demorar naquilo que é banal. Desenhar uma touceira de mato, por exemplo. Um papel amassado, uma caixa de fósforos. Outra questão que insisto com qualquer disciplina que ministre é a importância da memória na construção de um repertório que construa o imaginário do artista. A memória é fundamental para o estoque imagético do artista, a fundamentação de sua poética, a meu "ver". Devemos nos esforçar para isso. Enxergar o mundo de olhos abertos e conscientes do que estamos fazendo naquele momento, pode até ser uma receita zen de viver, mas é um método de trabalho ${ }^{257}$.

Nas maneiras de atuar de Frange, compreendendo o verbo atuar não como uma forma de representação, mas em sua etimologia, "fazer, colocar em movimento, estimular, realizar", a condição rizomática está presente. Há uma percepção de que toda vez que "uma multiplicidade se encontra presa em uma estrutura, seu crescimento é compensado por uma redução das leis de combinação" 258 . As estruturas quebram o rizoma, o aprisionam. Em função disso, não é possível compreender seus processos com base em uma linearidade, mas pensa-los como atravessamentos.

[...]. Então, o ator, para mim esse mediador, uma pessoa que tem que ter uma inquietude sustentada em si mesmo, que ele gera a inquietude no grupo e sustenta essa inquietude que constrói uma outra coisa, que é um outro lugar. Por isso ele é um ator. [...] ]eu fico procurando âncoras de pensamentos que me deem uma certa inquietude para acionar inquietudes. Porque, você vai fazer uma mediação para explicar para as pessoas o que é aquilo? Ou para dizer o que você entende a partir daquilo? 259

A mediação, na compreensão de Frange acontece por meio de forças aparentemente contraditórias. De um lado, há a rejeição da ideia de representação em prol da multiplicidade e de seus agenciamentos. Do outro, a representação surge como um fundamento epistemológico. Ou seja, ao mesmo tempo que atua disponibilizando um determinado repertório, que não corresponde a um modelo a ser seguido, acontecem como esboços, faz surgir

${ }^{257}$ Fragmento da entrevista concedida pela artista educadora AE2, em 2016, a Carlos W.M. de Souza.

258 DELEUZE, G. GUATTARI, F. Mil Platôs: capitalismo e esquizofrenia, Vol. I. Rio de Janeiro:34, 1995. p. 17.

259 FRANGE, L.B. Ibidem, 2016. 
um espaço de liberdade no qual o outro aciona a representação, a desconstrói e atua como criador. Não há uma tradução, o sujeito explicativo, o conhecimento surge como algo dinâmico, na prática do seu próprio exercício.

[...] Explicação é você querer traduzir para o outro o que você interpreta daquilo. Isso que acho ser complicado. Agora, você tem o compromisso, a obrigação de não sonegar informações. Você tem que situar as pessoas. Se você está falando de concretismo ou neoconcretismo para pessoas que não sabem o que é, você tem, no mínimo dizer o que é. Quando, onde, porque, pessoas. Porque eu posso estar falando do século XVII ou XX, eu posso estar falando de coisas que ainda vão acontecer, de um grupo que está começando agora. Se eu estou falando de concretismo ou neoconcretismo são coisas datadas. Então eu não posso sonegar essas informações para as pessoas. Isso é informação. Agora, ao mesmo tempo...vou citar um exemplo concreto. Vamos pensar no Éden de Oiticica ${ }^{260}$. Para as pessoas entenderem o Éden, preciso falar um pouco de Oiticica, preciso falar um pouquinho de Rio e Nova York, de quem era esse pensador, de quem era esse artista. Ele não foi só artista, ele escreveu, muito. Ele não só produziu trabalho de arte, publicou. [...] Aí você tem que criar essa condição de ator, para você e para o grupo como um todo, e produzir o acontecimento ali. De falas, de perguntas, de dúvidas, e até de perguntas estapafúrdias, como a clássica "o que o artista quis dizer com isso? ". [...] Normalmente, as pessoas perguntam isso. Alguns ficam muito irritados, mas as pessoas estão acostumadas a um sistema educacional o tempo inteiro a serem levadas a isso. Então eu acho que tem muita cobrança de uma certa objetividade e muito pouco espaço para poeticidade [... $]^{261}$

Frange suscita problemas, em sua narrativa, que não podem passar à margem dos processos que envolvem o ensino e a aprendizagem da arte, no que se refere ao lugar do educador: A primeira reporta à instituição escola, que conserva a existência de um mestre explicador que gera a acomodação; a segunda, a um conceito de igualdade que, em sua concepção, só pode existir se tiver seu equivalente na diferença.

[...] Eu mostro a imagem, e digo A Fonte. Primeiro, porque se chama $A$ Fonte? Eu também não sei, mentira, é claro que eu sei (risos). Mas um jeito de trabalhar com as pessoas e deixa-las à vontade é dizer que você também não sabe. Eu não sei, fiquei encucada, 1917[...] $]^{262}$

\footnotetext{
260 Éden não é concebido como exposição de arte destinada a apresentar a trajetória de um artista em terra estrangeira ou ainda como cenografia exótica para "ambientar" obras e público. Nem mesmo como aposto às obras ou seu complemento. Éden é um projeto, brotamento de brotamentos, patamar extremo das reflexões do artista naquele momento, planejamento ambiental (Oiticica, 1968 in Figueiredo, 1996: 42): Em Éden, Oiticica reúne Bólides, Penetráveis, Parangolés e Ninhos, seu percurso desde as primeiras obras do Neoconcretismo, em que realiza a "procura de 'totalidades ambientais' que seriam criadas e exploradas em todas as suas ordens, desde o infinitamente pequeno até o espaço arquitetônico, urbano. Figueiredo, L., (org.), (1996). Lygia Clark - Hélio Oiticica: Cartas, 1964-74. Rio de Janeiro: UFRJ.

261 FRANGE, L.B. Ibidem, 2016.

262 FRANGE, L.B. Ibidem, 2016.
} 
A poeticidade atua como agenciadora no jogo de antagonismos desmascaram os sentidos habituais articulados às expressões, acontecimentos e possibilita a parceria construída pela descoberta.

Você sai do seu lugar de autoridade, de sabedor e cai naquele lugar do ator, de viver junto uma peça que se está construindo junto.

Você está lá para trabalhar com pessoas. Você é pessoa, tanto quanto as pessoas que estão lá. Você está na condição ser um mediador, mas você está na condição de ser um provocador e um cúmplice de trabalho um grupo que se dispôs a ir lá ser mediado por você. Tem uma doação desse grupo para com você. Você é obrigado a ter uma doação para com ele $[\ldots]$

[...] Existe uma compreensão de que a ação educativa é você obrigar a pessoa a aprender alguma coisa, só que a aprender as coisas que você sabe, e não a aprender as coisas que não se sabe, nem você e nem ela. Vamos voltar ao Duchamp. Se eu vou para um grupo e falo para eles, vamos pensar porque se chama A Fonte, um mictório masculino. O que é um mictório, vamos pensar. A gente está em uma situação outra, não estamos em uma loja comprando mictórios. Estamos diante de uma exposição que tem um trabalho que se chama A Fonte. Tem data, tem assinatura, tem nome, tem tudo. É isso que estamos vendo. Então, eu não tenho que fazer as pessoas fazerem o percurso que eu fiz para estudar A Fonte. Eu tenho que usar esse percurso para provoca-la a produzir um conhecimento sobre $A$ Fonte. Então quando eu falo, vamos pensar juntos, eu não sei porque se chama A Fonte, uma pessoa pode me dar uma resposta que eu nunca pensei. Ela pode me contar uma história que eu nunca cogitei. E aí eu crio uma outra camada para essa fonte que eu nunca pensei. Que é A Fonte do Duchamp ... a pessoa pode me contar uma história e isso tomar um outro rumo. Mas aí eu puxo de volta. Nós estamos aqui discutindo A Fonte. Você contou super legal, pode ser uma outra camada, mas no nosso universo aqui, a gente tem um recorte. A gente está discutindo A Fonte, a gente já tem alguns dados. Aí você puxa de novo. Quer dizer, o tempo inteiro é um trabalho de pesquisa. A mediação é um puso ${ }^{263}$ [...] fica montando pedaços. Por isso que eu disse que é uma situação de ator...Desligue um pouco... (A senhora que trabalha em sua casa nos chamou para almoçar [...]

[...] Aí você vê a Angella ${ }^{264}$ no meio do matagal, vestida com uma roupa vermelha, de repente ele coloca umas ataduras aqui assim (Lucimar faz um gesto segurando os pulsos), coloca as mãos para trás, se ata naquilo (Figura 57). O que ela está falando de natureza, o que ela está falando de atadura, que roupa vermelha, o que é isso? Primeiro agora nós vamos parar, não vamos nem ver, nem ler. O que ficou para nós disso? O quer refletimos sobre o pensamento da Angella, que está propondo essas fotografias que são de árvores, mas são rasteiras no rodapé do museu, da galeria, seja onde for. O que ela quer que a gente entenda, o que ela está mostrando para a gente? Nós vamos fazer esse exercício. Depois vamos fazer o exercício com outra pessoa, a partir de um exercício que já fizemos. Porque não é só discutir matéria, ou verificar.... Em muitos momentos a gente fica em atitudes de

${ }^{263}$ A palavra puso, em espanhol, significa colocar-se no lugar de uma pessoa ou coisa; julgar a qualidade de uma coisa.

${ }^{264}$ Lucimar Bello se refere à Angella Conte, artista natural da cidade de Jaboticabal-SP, que vive e trabalha em São Paulo. 
verificar, constatar. O artista fez isso, deu conta disso, então é isso que eu entendi? Então é isso mesmo que eu vou passar para o outro. Não existe nada disso. Você não tem nem que constatar, nem que verificar, nem contribuir, nem passar, nem adquirir. São verbos que não cabem na ação educativa, cultural da vida. Não cabe! Oferecer é oferenda. Lá na religião é legal. Você não vai oferecer arte para ninguém. Você não vai passar o que leu do aluno, o que leu do artista, do teórico para ninguém. ${ }^{265}$

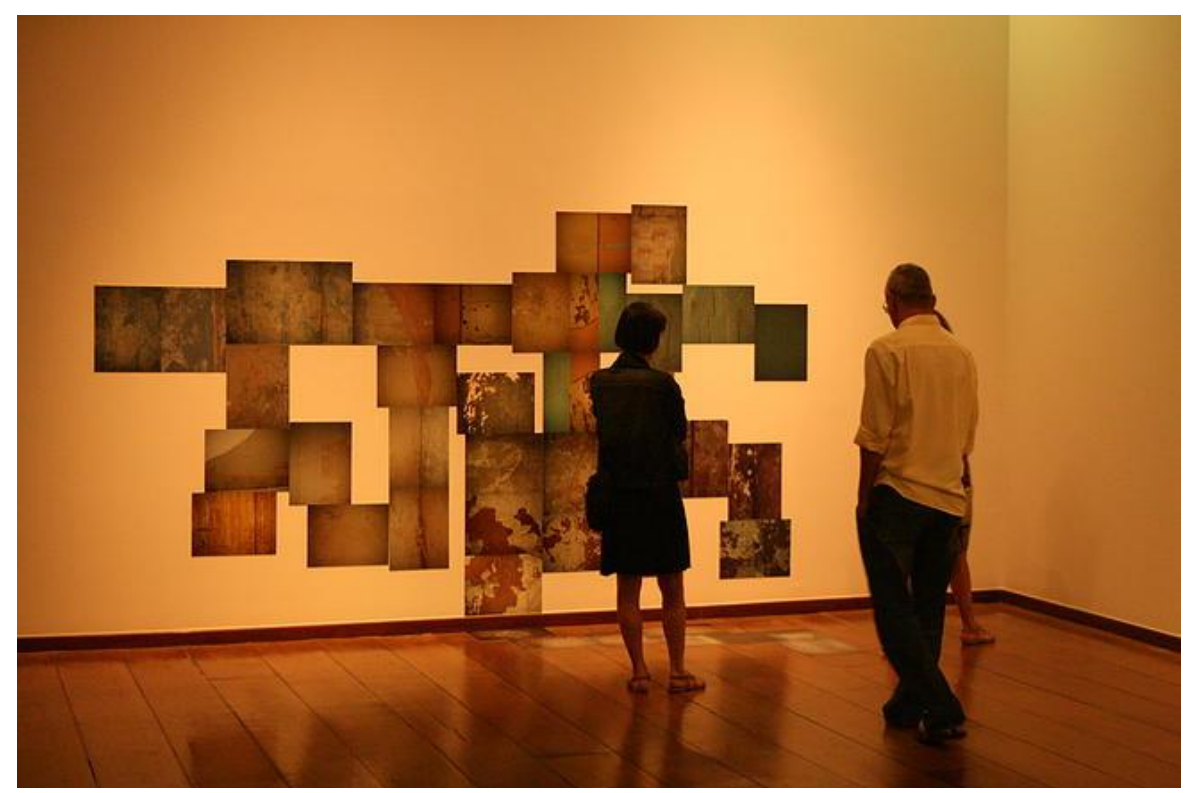

Figura 57. Fotografias. Essência 5'. Angella Conte. 150Salão de Arte Mam - Salvador-Bahia. 2009. Fonte:angellaconte.net.

\section{A questão do dissenso como elemento do processo educativo é} reafirmada por AE4 ...

[...] Há anos (em mediação) o que eu faço é ensinar pessoas a promoverem a experiência de imagem do outro (quando coordeno equipes de mediadores) ou vejo pessoas tendo experiência de imagem (quando observo o público)

[...] eu trabalhei sob uma ótica que me interessa muito dentro da mediação que é entender e compreender ... Mas, o passo posterior é uma opinião de dissenso. ${ }^{266}$

265 FRANGE, L.B. Ibidem, 2016.

${ }^{266}$ Fragmento da entrevista concedida pela artista educadora AE4, em 2016, a Carlos W.M. de Souza. 
A educação em arte assume um papel essencial na visão de Frange, como elemento constitutivo do sujeito. Segunda ela, "[...] produzir não acho que seja necessário, mas passar pela experiência estética é necessário. O que é isso? Eu não acho que você tem que fazer, mas eu acho que você tem que

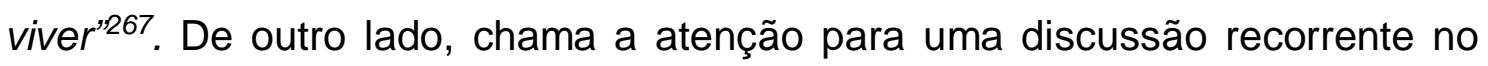
ensino da arte. A experiência estética é um processo criativo, que envolve mecanismos de compreensão que, necessariamente, passam pela vivência da arte. Destaca que não se trata de o educador ser um artista, mas de viver a arte. Estar em contato, munir-se por meio de experiências que desestabilizem os saberes constituídos. Dewey afirma que cenas confusas da vida tornam-se mais inteligíveis na experiência estética, "não do modo como a reflexão e a ciência tornam as coisas inteligíveis, reduzindo-as à forma conceitual, e sim por apresentar seus significados como o material de uma experiência intensificada, ou apaixonada" 268 . Ou seja, ...

[...] não que eu tenha que fazer, mas a experiência estética do outro. Como eu posso trabalhar com outros, sem viver a experiência estética em mim. Isso para mim sempre foi um problema.

Ainda segundo Dewey, há nas teorias representativas e cognitivas da estética uma ideia de suspensão contemplativa ${ }^{269}$. Frange não conceitua o valor educativo nessas concepções, principalmente, de que a arte tem como função educar a percepção. Menos ainda, como algo que fica restrito à experiência perceptual. Aborda a experiência estética como uma via de mão dupla, em que as qualidades brotam na relação direta com a vida. A experimentação, a vivência estética é o elemento imprescindível para que o processo formativo (de professores e estudantes) seja ativado, ...

Quer dizer, uma pessoa para escrever sobre o grande mestre, com a densidade que a Noemia escreveu, nos anos de 1940 e 50, não estou falando de 80, ela tinha uma vivência, uma experiência estética fabricada com ela, nela! Aí ela tinha a densidade da palavra. Assim, algumas pessoas eu acho que têm. Outras, não precisam ter, mas escrevem elas fazem música, elas dançam. Elas têm a experiência estética no corpo. Aí eles conseguem trabalhar com o outro, no corpo do outro, essa intensidade, essa intensidade da experiência estética,

${ }^{267}$ FRANGE, L.B. Ibidem, 2016.

268 DEWEY, John. 2010, p. 496.

269 Idem. p. 498. 
que é também estésica. Das estesias (Capacidade de compreender as sensações) $)^{270}$

Em sua abordagem sobre a leitura de imagens da arte em um processo que articula o estético, o ético e o político às imagens do cotidiano.

Leitura de imagem, tem que fazer leitura de imagem. Mas não dá para eu fazer só no contexto e na história. Eu tenho que fazer com perguntas do cotidiano que está aí. Se eu disser...A grande violência que está no mundo, agora...eu estava lendo a Folha e vi um monte de gente deitada...Eu vi o Goya! Como se chamava aquela ferramenta... do fuzilamento ...baionetas... estamos em 2014 e tudo acontecendo do mesmo jeito, esse massacre. Porque uns acreditam e outros não, são guerras religiosas. Se você não segue a seita, você tem que ser morto. Aquele monte de gente deitada, sendo fuzilada... Balas, balas de borracha e essas coisas todas que estão aí. É claro que isso é contexto, mas não dá para pensar nenhuma dessas áreas sem grudar o ético, o estético e o político. [...]

[...] eu acho que a gente tem na palavra leitura (da obra) muito a significação verbal, na hora que encaminha o exercício ou se propõe a fazer uma leitura, acho que ainda tem esse peso, tem que ser transformado em palavra e em significado, [...] mas eu fico pensando que talvez, eu também tenho muitas dúvidas, uma das possibilidades fosse pensar vamos pegar o objeto (vamos pegar esse daqui e coloca o molho de chaves sobre o papel) que está pintado lá, vamos fazer a pintura que está ali pintado, lá é pintura, aqui é objeto, então eu vou ler essas coisas juntas. Penso eu que, ao fazer essa leitura, eu tenho que fazer uma leitura dessas coisas, da relação entre essas coisas e uma leitura eu, essas coisas e essas coisas no mundo comigo, porque senão não tem sentido. (A leitura) tem que ser estética, ética e estésica, junto! [...] $]^{271}$

Essa amalgama, entre as dimensões ética, estética e política somente são efetivadas quando o saber docente, encontra um caminho para orientar e estimular a inteligência do aluno - tão discretamente, que a fazem trabalhar, mas não o suficiente para abandoná-la a si mesma ${ }^{272}$. Este processo de trocas, em que não há uma verticalização, deve alcançar um estado de compartilhamento, em que a arte, o estético não seja abordado em sua transcendência. A experiência cotidiana, as incertezas de ambos os lados (educador e educando) devem ser percebidas como alimento ao próprio processo de criação, na arte e na vida. Nesse sentido,

270 FRANGE, L.B. Ibidem, 2016.

271 FRANGE, L.B. Ibidem, 2016.

272 RANCIĖRE, Jacques. O mestre ignorante. Cinco lições sobre a emancipação intelectual.

Trad. Lilian do Vale, Belo Horizonte: Autêntica, 2002, p. 143 
[...] não dá para ensinar a ler, como não dá para ensinar a ler nada, cada um vai ler de acordo com seu universo [...] é uma leitura sobre para onde se pode ler e fazer o que com essa leitura, é muito difícil e muito perigoso fazer isto! [...] a escola para mim está na rua, na cidade, nos espaços públicos ... o banco da sala de aula, para mim, migrou para o computador, para a padaria, para vários lugares. Eu acho que sempre foi assim, mas hoje mais ainda. É um sistema de formação, do qual a escola é um dos fragmentos ... Estou falando de uma escola mundo! 273

A abordagem de Frange passa pela presença viva da arte no sujeito. É um modo de agregação e circulação na qual o que importa são os encontros as práticas colaborativas que não permite a distância do explicador. Os percursos do artista, do professor e do estudante, convergem nas maneiras como o trabalho é desenvolvido, mostrado. As imagens são uma condensação dessas trajetórias, contaminações com as histórias e campos de saber. Há nesse processo o entendimento de ...

[...] que vivemos numa sociedade que precisamos do dinheiro, mas esse sistema de produção de arte para o mercado não me interessa, ... porque ele vai me tirar a potência do trabalho ser feito com as pessoas.......] no trabalho com a comunidade eu entendo que, ou você assume um compromisso de formação, e, aí é o meu lado de chamar de "educadora permanente" (aspas no ar) ou você não faz. [...] não sei se eu te falei do Norval Baitello Junior? Eu li o último livro dele, o "Pensamento Sentado", como as pessoas podem aprender alguma coisa se elas passam o tempo inteiro estão confinadas a ficarem sentadas, o homem não foi pensado, nem criado para ficar sentado, ele é um andarilho ... é quase viver no mundo na situação de "deslugar", uma vez que você não é andante, seu pensamento também vai ficando confinado. ${ }^{274}$

Ao se referir ao projeto Semana Desenhante, configurado como extensão universitária, Frange sustenta a relação arte-reflexão e suas contribuições para pensar o mundo, bem como as barreiras enfrentadas quando o educador se posiciona nesse viés:

[...] a oficina de desenhos urbanos é uma das famílias de trabalhos educacionais que marcaram minha trajetória ... era um projeto longo para durar, no mínimo 4 anos, mas durou 2 anos, era Uberlândia pensando a cidade, o Plano Diretor ... as Secretarias e os cursos da Universidade, a Secretaria de Cultura muito envolvida, era um momento muito profícuo, de pensar e executar (anos 1980). Aí nós resolvemos propor que as crianças e os jovens fizessem propostas para a cidade, era uma proposta na qual as pessoas poderiam desenhar a cidade que gostariam de viver. Se os arquitetos, os

273 FRANGE, L.B. Ibidem, 2016.

${ }^{274}$ FRANGE, L.B. Ibidem, 2016. 
antropólogos, os geógrafos estavam pensando a cidade, por que as crianças e os jovens também não poderiam pensar, eles também moram na cidade, eles vêm a cidade de um outro lugar. Pretendíamos abordar três segmentos, crianças e adolescentes; seguros, assegurados e presidiários (todos que estivessem ou se sentissem presos) e idosos. Executamos apenas a primeira etapa, inclusive, porque foi um projeto muito pouco respeitado dentro da Universidade, mas fizemos muita coisa, mapeamos, fizemos livro escrito a 26 mãos, gráficos para explicar as propostas ... aí a Prefeitura deu um prêmio para nós, eu fui lá e disse que não era algo para ser premiado, agradeci muito, mas eu dizia: Isso é uma proposta para a cidade!

[...] o processo da Oficina de Desenho Urbano funcionava assim, nós panfletávamos, chamando para a praça. Ali explicávamos para as pessoas (crianças e jovens) que aquele processo tinha haver com $o$ Plano Diretor, o que era isso e que nosso papel era ajudar a pensar a cidade. Aí cada um recebia uma folha de papel e uma caneta, porque caneta não apaga, e, pedíamos para desenharem a cidade que tinham e a cidade que queriam. No final elas poderiam dar para nós o desenho, se quisessem (a maioria nos deu) e colocávamos um carimbo, com a idade, o lugar, o nome, a escolaridade e tudo isso ia para um varal. $A$ pessoa tinha que estar ali porque queria, e, foram muito poucos os que buscaram materiais em casa ou que desenharam coisas como o Mickey, um percentual mínimo, mais ou menos $2 \%$, pessoas que não responderam ao que pedimos. Teve gente que escreveu texto e nós consideramos como desenho, porque era uma forma de responder aquilo que a gente estava perguntando. De muitos anos sempre foi essa atitude, de trabalhar com as pessoas e as pessoas comigo ... nessa proposta era passar o dia desenhando e as pessoas eram convidadas a desenhar comigo. ${ }^{275}$

É evidente que se vive em um tempo em que a prática do pensamento se acomodou e, no ambiente escolar, esse fenômeno tem consequências muito sérias. Quando Frange lembra a obra de Norval Baitello Júnior, o "Pensamento sentado - sobre glúteos, cadeiras e imagens" 276 está se referindo à passividade que não interpela o mundo, que não caminha e percebe o que está através das janelas, que levam ao outro lado. Sua escolha, na arte, na educação não permite o olhar sentado. Incorpora o olhar nômade, mesmo em ambientes institucionais, como na ...

[...] (Oficina ligada à exposição no Sertão do Cariri) ... para uma sala de aula, o que eu posso fazer que transgrida o fato de que eu estou lá em uma sala de aula, ensinando alguma coisa? Fiz um elenco de palavras, coloquei no quadro, só a metade da palavra, pedi para as pessoas copiarem, mas copiarem como eu estou fazendo aqui, deixem espaços, espaço em cima espaço em baixo, as pessoas sabiam que iam entrar coisas ali, mas que coisas? ... aí começa a vir um fluxo de palavras e as pessoas começam a perceber que ali existe uma

275 FRANGE, L.B. Ibidem, 2016.

276 JÚNIOR, Norval Baitello. O pensamento sentado: sobre glúteos, cadeiras e imagens. Ed. Unisinos, 2012. 
estrutura anterior pensada que eu tinha tirado, lá eu mostrei a trilogia de vídeos dos Alpes ao llha de Capri ... por que dos Alpes ao llha de Capri e todo mundo quer corrigir, não estou falando da llha de Capri, dos Alpes é do edifício que chama Alpes ao edifício que chama llha de Capri, porque a palavra edifício está comigo, [...] os alunos que estavam comigo sabiam que tinham essas pegadinhas, eles viam "ade" e pensavam em cidade. Eu ia complementando as palavras em outra cor, algumas descobria e outros não descobria, e, aquilo era um mapa das palavras que eu estava trabalhando na exposição e as possíveis palavras que eles poderiam desdobrar do nome da exposição. Eu disse para eles, a única coisa que eu podia fazer aqui, era pegar o próprio verbal da exposição (que eu queria fazer dentro da exposição, mas todos vocês viram a exposição, porque era uma condição para se inscrever) ... na oficina, tem um tempo definido, e passa pela questão de contrato, eu estou disponível, você quer, a gente sela um contrato, se a pessoa não quiser ela vai embora, mas se ela fica, ela fica, eu também fico, porque sei que ela está ficada comigo, isso é ético! [...] dar aula na rua, é muito mais complicado preparar a aula na rua ... ${ }^{277}$

Muitas vezes, as práticas artísticas contemporâneas não são compreendidas, no âmbito educacional. A maneira como os artistas estabelecem suas estratégias, como dão unidade, pelo processo de criação a algo que não, necessariamente se torna palpável, ainda habita o senso comum e traz algumas inquietações pertinentes que estão implícitas na narrativa de Frange. Durante o processo de pesquisa em espaços expositivos sentiu-se esse conflito entre os professores de arte. Expressões como " hoje em dia tudo é arte", "onde está a beleza nisso", "isso é conceitual", "não é necessário mais saber fazer para ser artista" foram constantes nas falas dos docentes em bienais e outros espaços observados na trajetória de execução da pesquisa. Obviamente, que se estas questões são importantes para os docentes, devem ser tratadas com respeito. Este conflito está relacionado à algumas concepções que podem ser refletidas de maneira muito objetiva: a impressão de que a arte do passado é superior a do presente; de que não há a necessidade de estudos sobre dos códigos e as linguagens para se chegar a uma configuração, são apenas algumas dessas concepções. Quando Frange afirma que,

[...] quando eu dava aula de perspectiva, como fazer uma caixa, você tem que saber o mínimo de perspectiva, ... para os alunos aprenderem a transformar a tridimensionalidade no papel, depois você pode transformar no que você quiser ... esse saber mínimo, tem saberes que são fundantes, o saber fazer é alicerce ... o alicerce sustenta, é o mesmo caso do conceito, se não tiver você não sustenta seu trabalho. ${ }^{278}$

277 FRANGE, L.B. Ibidem, 2016.

278 FRANGE, L.B. Ibidem, 2016. 
.. está tratando dessas questões. A comparação entre a produção estética pretérita e a atual, está nos valores atribuídos pela cultura, pelo que é comum na aceitação e incorporação aos modos de ver, dizer e fazer. Isso não significa que foram descartadas, apenas que são valores no tempo e no espaço de suas relações.

As rupturas com a ideia de forma/imagem e os valores atribuídos a ela, não encontram abrigo nos modos contemporâneos de fazer porque os problemas são outros. No entanto, os saberes da arte (técnicos - saber fazer) (estéticos - simetria, movimento, equilíbrio, e inúmero outros) permanecem os mesmos. Apenas não estão confinados na "fôrma", assumem os riscos da linguagem ao seu limite e devem ser pensados sob as condições de articulação das próprias poéticas. Está é uma condição imprescindível, para que mesmo no que se refere às incertezas da produção contemporânea, se possa avalia-la e trazê-la ao campo das reflexões sobre educação com propriedade e inteligência, de maneira a contribuir para uma tomada de posição estética, que também é ética. Esta orientação pode impedir que os modismos e preconceitos não assumam o lugar da coragem de enfrentar as incertezas. Para finalizar, Frange lembra Beuys e seus trabalhos com as oficinas de desenho.

[...] uma grande figura, uma grande cabeça, ele falava que toda pessoa é um artista. Nós da arte educação não lembramos que ele existe. Até os anos 90 tem um alicerce de artistas que vão para o mundo, vão para rua, [...], ando irritada com alguns coletivos que fazer performance e as pessoas batem palmas, virou objeto de novo?

[...] Na Universidade muitas vezes foi difícil, porque eu ia trabalhar nos bairros, e, volta e meia, diziam que eu não estava dando aulas. A sala de aula é muito cômoda, mas para é muito pouco, não desafia!

[...] trabalhar com as pessoas torna tudo mais complexo, você está trabalhando com pessoas, com a inserção delas nesse espaço, todas as inquietude e paixões que elas têm em relação a esse espaço, é tudo junto, extremamente complexo, mas por isso é que é bom, é um desafio permanente. Eu não sei se isso é trabalhado com o que a gente chama de mediação ...

[...] o Beuys, quando ele leva a lebre para a galeria, ele chama atenção como alguém que tinha uma pegada para educação, e, certamente ... muitos outros artistas pensaram sobre educação, mas ele cria um certo alicerce para a arte contemporânea e quando ele planta o trabalho dos 100 carvalhos e diz que o trabalho ficaria pronto quando crescesse, a relação dele com a comunidade, com as pessoas ... quando ele planta os carvalhos não o faz em qualquer lugar, mas em Kassel, que era uma 
cidade para ser arborizada novamente, ele tem essa proposta social, cultural e o que chamamos de colaborativa. ... Concordo com ele quando diz que todos somos artistas, se você considera que a arte é uma camada de invenção na arte e na vida, e, talvez seja o lugar onde mais você possa exercitar a capacidade inventiva, porque não tem fronteira, não essa arte mercadológica, mas nesse sentido expandido da arte mesmo. 279

O Quadro 07 sistematiza os dados coletados por meio das entrevistas, conforme as categorias de pesquisa.

279 FRANGE, L.B. Ibidem, 2016. 
Quadro 07: Derivações da análise de entrevistas

\begin{tabular}{|c|c|c|}
\hline PRÁTICA ARTÍSTICA & IMAGEM & PROCESSOS PEDAGÓGICOS \\
\hline $\begin{array}{l}\text { - Processo criativo a partir das coisas } \\
\text { do mundo, das mínimas coisas; } \\
\text { - Importância do cotidiano e dos } \\
\text { elementos ordinários na produção; } \\
\text { - O corpo como ponto de partida da } \\
\text { criação; } \\
\text { - A mobilização das questões } \\
\text { estéticas; } \\
\text { - Uso da linguagem como meio } \\
\text { expressivo; } \\
\text { - Embate palavra/imagem no centro do } \\
\text { processo criativo; } \\
\text { - Relação do imaterial e do material } \\
\text { inerente à ação prática; } \\
\text { - Processualidade na arte e na vida; } \\
\text { - Envolvimento arte e comunidade; } \\
\text { - Permuta de saberes no processo } \\
\text { criativo. }\end{array}$ & $\begin{array}{l}\text { - Imbricamento imagem / conceito / } \\
\text { pensamento; } \\
\text { - Forma / imagem como modo de } \\
\text { operar; } \\
\text { - Investigação / percepção se } \\
\text { conectam ao conjunto da } \\
\text { experiência; } \\
\text { - Trabalho só se realiza na relação } \\
\text { com o outro: estética relacional; } \\
\text { - Importância da tensão entre o } \\
\text { projetado sólido e a fragilidade } \\
\text { extrema. }\end{array}$ & $\begin{array}{l}\text { - Compartilhamento como fio condutor do } \\
\text { processo educativo; } \\
\text { - Exercício permanente das práticas } \\
\text { colaborativas e da coletividade como meio de } \\
\text { aprendizado / criação; } \\
\text { - Horizontalidade no processo ensinagem; } \\
\text { - Inseparabilidade entre as dimensões do ser } \\
\text { artista, educador e professor; } \\
\text { - Exercício da mediação pelo dissenso; } \\
\text { - Compreensão do conhecimento como } \\
\text { processo dinâmico que surge da prática, do } \\
\text { exercício do fazer; } \\
\text { - Poeticidade como agenciamento de } \\
\text { antagonismos; } \\
\text { - Importância da experiência estética na } \\
\text { formação de professores; } \\
\text { - Elementos relevantes na leitura de imagem: } \\
\text { ético/estético/político; } \\
\text { - Incertezas (educador e educando) alimentam } \\
\text { o processo criativo na arte e na vida. }\end{array}$ \\
\hline
\end{tabular}

Fonte: Análise e Interpretação de Entrevistas Organização própria 


\subsection{Observação Participante do Trabalho Desenhos de Comer}

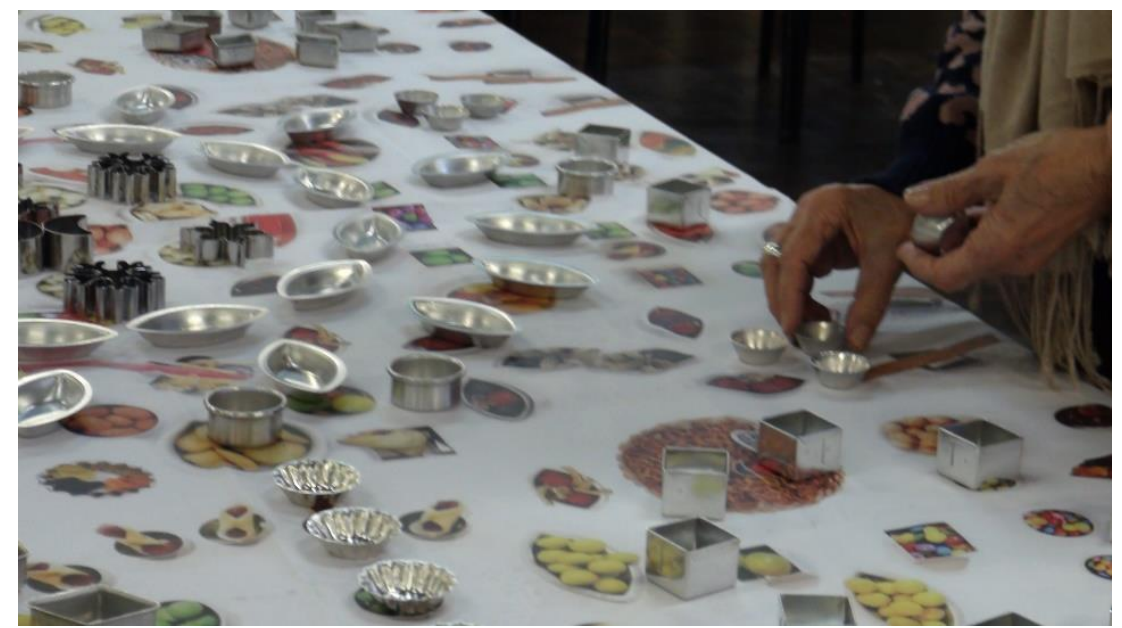

Figura 58. Performance "Desenhos de comer". Lucimar Bello Frange, 2016. Curitiba - PR. Fotografia: Carlos Weiner M. de Souza.

A realização da observação participante em uma das Oficinas do trabalho intitulado "Desenhos de Comer" constituiu uma espécie de corolário da pesquisa empírica (Figura 58). Isto porque possibilitou que houvesse uma percepção distinta e, ao mesmo tempo, complementar do processo de ensinar e os entrelaçamentos que Frange estabelece com a produção artística. Realizada na cidade de Curitiba, promovida pelo Departamento de Artes da Universidade Federal do Paraná ${ }^{800}$, foi desenvolvida entre 15 e 16 de junho de 2016 e oferecida para estudantes e professores de Artes, contando com 20 participantes ${ }^{281}$ (Figura 59).

\footnotetext{
${ }^{280}$ A produção do evento foi realizada por Carlos Weiner M. de Souza, que também compôs as mesas de debate juntamente com a professora doutora Consuelo Chalita, DO Departamento de Artes da Universidade Federal do Paraná - UFPR.

281 Em função da ênfase no processo pedagógico, optou-se por analisar e interpretar as observações realizadas ao longo do desenvolvimento da Oficina Desenhos de Comer em um texto único. Ao longo dele são promovidos os destaques às três categorias de pesquisa.
} 


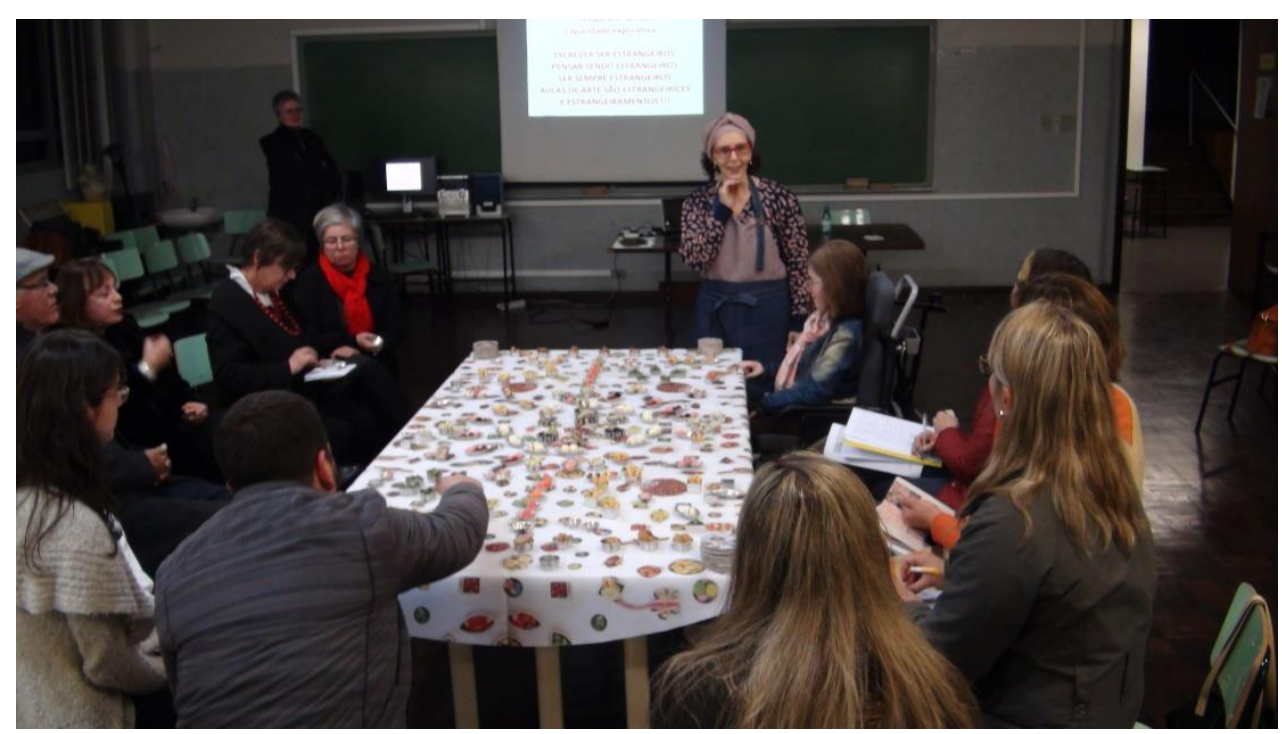

Figura 59: Imagens da execução de Desenhos de Comer, Curitiba, 2016

O processo foi dividido em dois dias. O primeiro dedicado ao que Frange definiu, a propósito das burocracias institucionais, de "Palestra: Arte contemporânea, desafios e proposições". O segundo dedicado ao tema "Conversas: Literatura, artes visuais e design gráfico". O trabalho que se multiplica desde o ano de 2009, não é uma palestra, mas uma performance ${ }^{282}$. Trata-se de um projeto contínuo entre cidades, lugares espaços diversos. Segundo Frange são ações que geram atos estéticos, éticos, políticos, culturais partindo de comíveis miúdos. A questão central pela qual sintetiza a essência do processo é: se comermos o desenho, como ele fica no mundo?

Frange revela um propósito de realiza-lo em ao menos uma cidade em cada estado brasileiro, percorrendo o território nacional, com suas diferenças e riquezas culturais particulares. Não estabelece um prazo, não é uma meta, mas um desejo, que requer que muitas energias se combinem para a realização efetiva. Sua execução assume a lógica do ator em rede, trata-se de uma costura de diversos modos de ver e ser, são camadas agregadas a cada realização.

Instaurar estados de dúvidas. Este é o primeiro passo de uma caminhada oposta ao já sabido, o já visto, o já experienciado. Os encontros devem se

\footnotetext{
${ }^{282} \mathrm{~A}$ imagem, mesmo no âmbito acadêmico dos cursos de artes visuais, ainda tem sido tratada de maneira conservadora. Para que projetos como "Desenhos de comer" estejam presentes nesses ambientes, faz-se necessário denomina-los como palestra. A práxis artística e seus modos de circulação, ainda não foram assimilados como algo que, por si, seja reconhecido como uma forma de conhecimento. A mediação da palavra explicativa e justificadora de saberes ainda assume um lugar de referência, o que por sua vez, impossibilita experiências mais extensas e a compreensão do estético no âmbito da formação.
} 
configurar como momentos de compartilhamento e de construção de conhecimento. As dúvidas cercam educador e educandos, representam tensões substanciais para o desenrolar da proposta, são elas que instigam o processo. O desafio do educador está em criar esse estado de coisas. De compreender que encontrar

[...] um território é também encontrar uma distância. A minha distância em relação ao outro comporta uma ética. A distância que é preciso demarcar, não avançar, a justa distância que permite o comum. A experiência estética é uma experiência no mundo comum ${ }^{283}$.

Assim, na observação realizada, o primeiro aspecto que chama atenção é a organização do espaço e a recepção dos participantes. Frange toma como ponto de partida o desenho e subverte sua lógica ao desenhar com as coisas do cotidiano, com as mínimas coisas. O centro do processo é constituído por uma mesa posta para que os participantes se sirvam e comam ao longo do desenvolvimento da performance. Aqui está o elemento central de sua prática artística, trazer o cotidiano e estabelecer o "não lugar". Ao criar a mesa para aquele grupo, compreendendo as particularidades do lugar, da cidade, da Universidade, do grupo, a artista estabelece um meio de territorializar-se, fazendo-o pela escolha e pela escuta do que entra e o que não entra no processo composicional. O agenciamento acontece na produção de um espaço curvo que

Oculta consciência de não ser,
Ou de ser num estar que me transcende,
Numa rede de presenças e ausências,
Numa fuga para o ponto de partida:
Um perto que é tão longe, um longe aqui.
Uma ânsia de estar e de temer
A semente que de ser se surpreende,
As pedras que repetem as cadências
Da onda sempre nova e repetida
Que neste espaço curvo vem de ti ${ }^{284}$.

Frange trouxe a toalha impressa com motivos comestíveis. Essa toalha é formada pelas memórias de outras execuções do projeto. No dia de sua performance, caminhou pelas ruas de Curitiba para conversar com as "fôrmas" e as "fórmas" que fariam parte da performance. Esse não é apenas um ato de

\footnotetext{
283 LIMA, Elizabeth. Acerca das cartografias cidadianas de lucimarbello da Vila Olímpia, 2006. Disponível em: <http://www.lucimarbello.com.br>. Acessado em : maio de 2014.

${ }^{284}$ SARAMAGO, José. In Poemas Possíveis. Editorial Caminho, Lisboa, 1981. 3. Ed.
} 
escolhas, é uma imersão, algo necessário para que as coisas e objetos ganhem vida. Há também uma escuta permanente, não apenas das pessoas, mas dos objetos inanimados, uma sensibilidade para as coisas do mundo. A escolha dos objetos que compõem a mesa não se desconecta dos elementos estéticos, cores e tons associam-se a odores e sabores em um processo sinestésico (Figura 60). No movimento da escuta há os elementos excluídos, auto excluídos, talvez. Acerca disso, pondera sobre suas percepções e leituras de um contexto de "futuro sombrio e medo" que a mídia, atualmente, impõe no Brasil e que em função da discordância sobre isto teria trazido papéis que iriam compor a mesa, neles havia escrito "não silenciados". "Mas essa mesa rejeitou esses papéis, então eu só vou contar. A mesa não quis aceitar palavras" ${ }^{285}$.

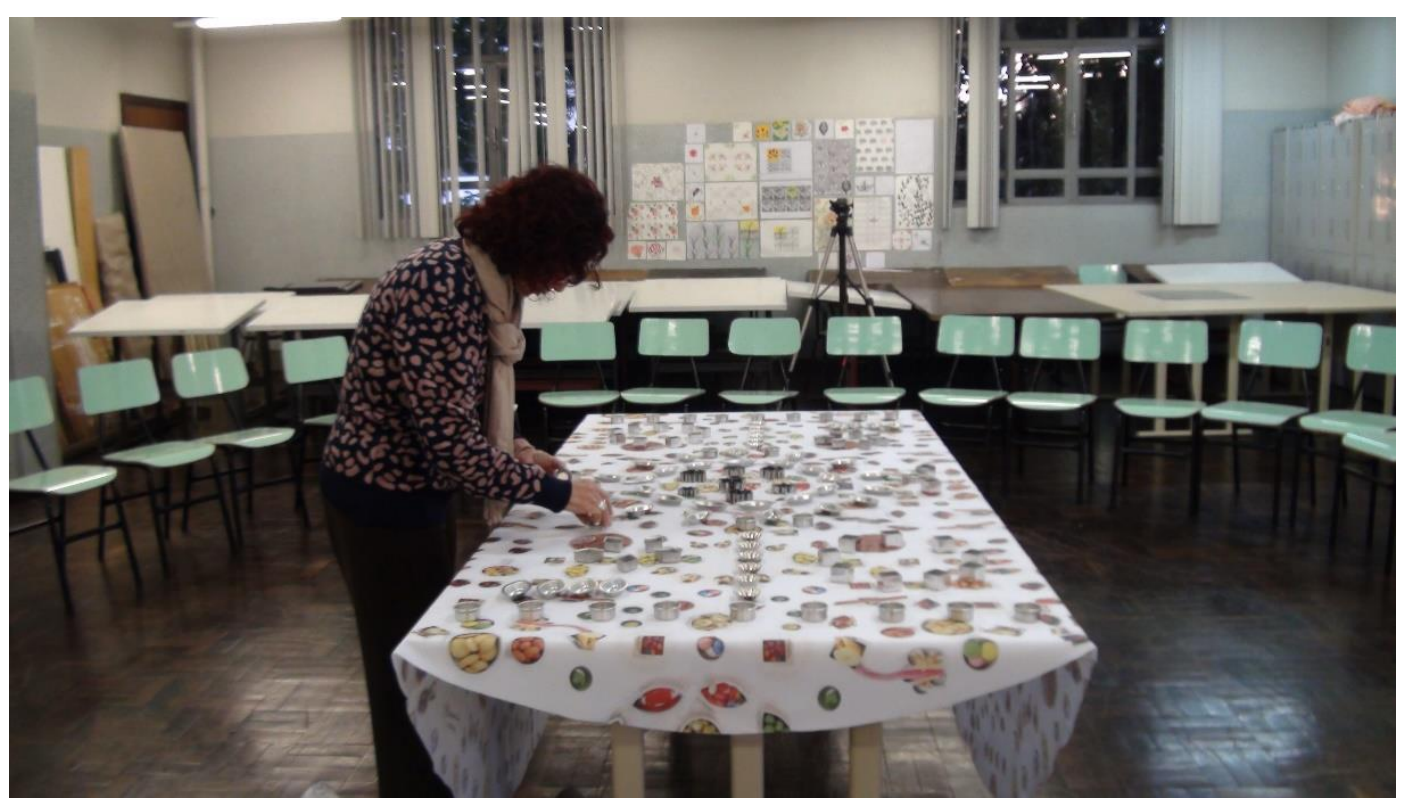

Figura 60: Organização da mesa e do espaço, Curitiba, 2016

Seu desenho, no entanto, não representa uma obra, trata-se de um ponto de partida, uma linha no mundo para iniciar a costura do trabalho que será desenvolvido e completado, potencialmente, pelo grupo. A partilha dos objetos comestíveis, o ato de comer e de estar juntos, o não lugar representado pelo simples fato de trazer para dentro de um espaço de aprendizado um gesto simples e fundamental da vida humana, o de comer, constituem elementos, matérias-primas que possibilitam a realização do trabalho artístico.

285 FRANGE, L.B. Ibidem, 2016. 
Convida o grupo a esse processo construtivo, a esse coletivo do processo criativo: Propõe: "[...] comam, não vou servi-los, enquanto falo vocês comem, mas sintam e vejam o que estão comendo. Ao terminarem, cada um pega um porta-copos". Provoca o grupo de forma inusitada com a questão: "se comermos o desenho como ele ficará no mundo?" A coletividade não se esgota no estar juntos fisicamente, mas no intervir no mundo e refletir sobre isso. Como afirma Ana Mae,

[...] a educação é mediatizada pelo mundo em que se vive, formatada pela cultura, influenciada por linguagens, impactada por crenças, classificada pela necessidade, afetada por valores moderada pela individualidade. Trata-se de uma experiência com o mundo empírico, com a cultura e a sociedade personalizada pelo processo de gerar significados, pelas leituras pessoais auto sonorizadas do mundo fenomênico e das "paisagens interiores" 286.

O desenho de fato se constrói pari passu no ato de intervenção que os participantes fazem à mesa, à medida em que realizam suas escolhas, se sentem atraídos a degustar determinados itens. Segundo Frange, dois atos se cruzam aí, o de escolher e o de levar à boca. O sentido produzido por esses dois atos tende a despertar memórias, trazê-las à tona representa um elemento relevante e constituinte do desenvolvimento do trabalho. Frange instaura a desestabilização da ideia de tempo linear. Provoca, a propósito da concepção deleuziana de tempo, saltos, acelerações, rupturas e lentidões em que as categorias de passado, presente e futuro se diluem nas malhas de um labirinto plástico ${ }^{287}$.

Trata-se de uma conversa performática, em que 0 seu corpo/palavras/gestos/pensamentos produzem as imagens de uma composição dinâmica. Por isso, relata que aos poucos foi entendendo que deveria produzir a si mesma para esse encontro de forma a também criar a ambientação necessária. Sua roupa é especial, veste-se como uma cozinheira, trajando avental e um lenço que prende os cabelos.

Ainda sob o aspecto da prática artística, Frange propõe uma mesa na qual as formas vêm de fôrmas e as fôrmas são preenchidas por formas que não foram produzidas nelas. A artista revela que, nesse caso, considera que os acentos da

${ }^{286}$ BARBOSA, Ana Mae. A imagem no Ensino da Arte. São Paulo: Ed. Perspectiva, 2007. p. 62.

${ }^{287}$ DELEUZE, Gilles (1985/1990). A Imagem-Tempo: Cinema II. São Paulo: Brasiliense. 
palavra forma são essenciais para traduzir seu significado no processo, são imagens. Indica ainda que as pequenas contradições e complementaridades compõem o processo de construção, criam significados.

A primeira etapa da oficina/performance envolve esse ato de comer, ao mesmo tempo em que ela apresenta sua fala, guiada por uma série de slides, que permitem pontuar diversas questões de ordem estética e artística, apresentar outras experiências e relatar percepções. Uma das primeiras pontuações que ela realiza se refere à relação entre comida / cultura e memórias. Ao mesmo tempo em que Frange discorre sobre o tema e problematiza, os participantes vão assumindo um comportamento cada vez mais imersivo: comem, direcionam seus olhos para as mãos e para a mesa. Observa-se um despertar de memórias, um estado que não se traduz em palavras, mas em gestos e sentimentos. Por meio da ação estética

[...] las representaciones sociales son entidades casi tangibles. Circulan, se cruzan y se cristalizan sin cesar en nuestro universo cotidiano a través de una palabra, un gesto, un encuentro. La mayor parte de las relaciones sociales estrechas, de los objetos producidos o consumidos, de las comunicaciones intercambiadas están impregnadas de ellas. Sabemos que corresponden, por una parte, a la sustancia simbólica que entra en su elaboración y, por otra, a la práctica que produce dicha sustancia ${ }^{288}$.

Assim, ao mesmo tempo em que levanta questões e discussões temáticas, Frange também revela sua concepção de imagem, "[...] estou sempre trabalhando com a estética do frágil, do ordinário, do mambembe". Sua busca é por um despertar de um estado de arte, um estado criativo "que insinua possibilidades de relações humanas não encontradas nas regras e preceitos na admoestação e na administração" 289 . Nesse sentido, aponta para uma relação entre produzir arte e ensinar arte, a proposição artística é também educativa, pelo poder da projeção imaginativa. Frange entende que ao provocar o estado criativo, instiga cada sujeito a um novo lugar, um novo eu. Para ela, trata-se de um fazer investigativo, que classifica como pesquisa-ação. "No que estou pensando ao construir esse processo: uma proposição do artista, propositor e

${ }^{288} \mathrm{MOSCOVICI}$, Serge. La Representación Social: Um Concepto Perdido. In: IEP - Instituto de Estudios Peruanos Taller Interactivo: Prácticas y Representaciones de la Nación, Estado y Ciudadanía en el Perú Lima,2002. p.76.

289 DEWEY, John. 2010, p. 585. 
provador. É sempre uma proposição de instar um sujeito em estado de criação". 290

Ao longo de sua apresentação performática traz o relato da execução do primeiro "Desenhos de Comer" em que a mesa foi desenhada com cravos para espantar as formigas. "Afinal, por que a boca?" Ela entende que esse órgão é um focinho para o mundo, sua ação de fala externaliza o que está no âmago do sujeito. O processo de ouvir e comer gera uma espécie de estesia, Frange relata sua percepção do grupo naquele contexto: "Vocês não estão falando, mas se vocês pudessem ver os olhos e a vibração que estão transmitindo, é de uma potência quase infinita. Estou com calor, eu estava gelada"291

Sua fala traz diversos elementos informacionais, mas o processo de aprendizagem é muito mais amplo, advém dessa interação, que começou a ser verbalizada após cerca de 30 a 40 minutos dessa vivência. Delicadamente, coloca a informação, rica e diversa, no segundo plano do aprendizado, condição relevante, mas não suficiente para que ele ocorra. Em especial, os relatos sobre o histórico do Desenhos de Comer geram curiosidades, alguns participantes querem compreender o processo, o que ocorre antes; outros querem saber mais sobre os lugares e até mesmo sobre o perfil dos grupos, se houve experiência com crianças.

Em outra perspectiva, alguns dos participantes trazem suas memorias e falam dos sentimentos despertados pelo processo, o acolhimento e aconchego e como isso é importante para sua inclusão no grupo. Há também intervenções relacionadas a outros artistas (referências artísticas que dialogam com essa linha de trabalho. O instigante é que, em nenhum momento, as pessoas perdem a mesa como referência. Ela de fato assume um papel nuclear, e, sem perceber quebram uma hierarquia estabelecida na sala de aula tradicional.

Ao final, Frange pergunta ao grupo: "Como foi comer, o gosto?" Várias pessoas apresentam seus sabores prediletos e a que eles remetem, mas também se deslocam para degustar o que está mais distante. Surge daí, o engajamento estético do futuro, que aciona relações e reações de uma memória ligada ao novo, ao educar-se como uma vontade de potência.

290 FRANGE, L.B. Ibidem, 2016.

291 FRANGE, L.B. Ibidem, 2016. 
O Quadro 08 sistematiza os dados coletados por meio da observação participante em Desenhos de Comer, conforme as categorias de pesquisa. 
Quadro 08: Derivações da Observação Participante - Oficina Desenhos de Comer

\begin{tabular}{|c|c|c|}
\hline PRÁTICA ARTÍSTICA & IMAGEM & PROCESSOS PEDAGÓGICOS \\
\hline $\begin{array}{l}\text { - Sujeito em rede; } \\
\text { - Mobilização pelo desejo; } \\
\text { - Trabalho na coletividade: se } \\
\text { completa no e com o outro; } \\
\text { - Uso de materiais comuns / } \\
\text { ordinários; } \\
\text { - A linguagem do desenho como ponto } \\
\text { de partida e intervenção no mundo. } \\
\text { - Estética do cotidiano } \\
\text { - Hibridação de linguagens (plásticas, } \\
\text { visual e literária). }\end{array}$ & $\begin{array}{l}\text { - Não objectual; } \\
\text { - São modos de operar em envolvem } \\
\text { objetos, visualidades, dizibilidades; } \\
\text { - O elemento material pode ser } \\
\text { transformado em objeto, que remete à } \\
\text { experiência integral dos modos de operar; } \\
\text { - Os referenciais (técnicos e estéticos) da } \\
\text { história da arte são incorporados ao } \\
\text { processo construtivo de acordo com as } \\
\text { intencionalidades. Não há uma separação } \\
\text { temporal, de gênero ou estilo, mas a } \\
\text { incorporação das referências por } \\
\text { problema a ser resolvido. }\end{array}$ & $\begin{array}{l}\text { - Estado de dúvidas como elemento de } \\
\text { mobilização do processo de aprendizagem; } \\
\text { - Processo de compartilhamento na } \\
\text { composição didática; } \\
\text { - A memória é ativada como um fenômeno } \\
\text { estético; } \\
\text { - Mobilização do tangível e do intangível na } \\
\text { construção do sujeito; } \\
\text { - Desierarquização da relação educador / } \\
\text { educando; } \\
\text { - O saber fazer (os aspectos técnicos e os } \\
\text { problemas estéticos devem ter unidade). } \\
\text { - Busca do despertar do estado criativo, } \\
\text { como centro do processo de aprender; } \\
\text { - Produção artística é tomada como ato } \\
\text { educativo; } \\
\text { - Relevância da informação e do repertório } \\
\text { do educador, como matéria-prima para o } \\
\text { processo de ensinagem; } \\
\text { - Educar é educar-se: processo contínuo, } \\
\text { aberto e multifacetado. }\end{array}$ \\
\hline
\end{tabular}

Fonte: Análise e Interpretação da Oficina Desenhos de Comer Organização própria 


\subsection{O processo de triangulação em diálogo com a problemática de pesquisa}

A diversidade metodológica característica das pesquisas intituladas como estudos de caso possibilita ao pesquisador uma abordagem que abranja desde os aspectos de caráter histórico, até os comportamentais. Cada um deles, conforme os propósitos da pesquisa e do pesquisador poderá será ser atendido por um método particular. Nessa pesquisa, em diálogo com os problemas estabelecidos foram escolhidos três caminhos de coleta, análise e interpretação de dados. Sendo assim, à medida em que ficou estabelecido o uso combinado de métodos distintos, cujos instrumentais são específicos, tornou-se premente proceder ao estabelecimento das linhas de convergência de investigação. Elas são responsáveis por guiar o processo conhecido como triangulação de dados. Reitera-se que esta não consiste em um método em si, mas em uma estratégia de pesquisa apoiada em outros métodos, devidamente validados $^{292}$.

O procedimento escolhido para realizar essa convergência de resultados, conhecido como triangulação de dados, toma como pressuposto que as estratégias de pesquisa corroboram entre si. Os fios condutores do processo de pesquisa são as questões de pesquisa. Trata-se de uma estratégia válida e eficaz, conforme indica Minayo ${ }^{293}$. Além disso, constitui um modo de avançar em relação às dicotomias estabelecidas no âmbito das ciências, em particular das Ciências Sociais, que oscilam entre as matrizes qualitativa e quantitativa. A síntese de fato está no objeto de pesquisa. Nesse caso, o objeto está no papel da experiência com e da imagem no âmbito do ensino da arte no contexto do contemporâneo.

Compreender as práticas artísticas contemporâneas e derivar suas contribuições para o ensino da arte constitui uma problemática teórica. Todavia, em termos práticos considerou-se que a elaboração de estudos de casos e análises comparadas constituiriam um caminho frutífero para avançar nesse campo de alta complexidade e relevância para a arte-educação brasileira. Nesse sentido, três questões nortearam o caso articulado em torno do trabalho da artista educadora Lucimar Bello Frange: como suas práticas artísticas se apresentam ao longo de sua trajetória, estabelecendo os anos 1990 como marco de pesquisa; como a experiência da, e com a imagem se realiza em seu trabalho e como são ativadas as políticas cognitivas por meio da experiência com e da imagem. Estas remetem a questões mais gerais sobre as contribuições da arte

292 YIN, 2010. Op. Cit; MINAYO et.al., 2015. Op. Cit.

293 Idem, Ibidem. 
contemporânea para as reflexões teóricas e práticas da arte educação no cenário de narrativas que não se fixam à ideia da universalidade.

A análise e interpretação da prática artística do ator chave representam seu ponto de partida e de chegada. Isto porque estão fundidas de forma muito consistentes a vida e o trabalho, dentro desse, o trabalho artístico e o de educador. Há um emaranhado, um tom de realidade que por si irrompe à lógica positivista que procura um lugar para cada coisa e uma coisa para cada lugar. A experimentação e a percepção do corpo como ponto de partida da criação se apresentaram de maneira muito contundente, seja na sua trajetória, nas entrevistas e mesmo na observação de uma das execuções de Desenhos de Comer.

O entrelaçamento da materialidade e da imaterialidade assume novas cores, estando imiscuída ao processo de desierarquização e desmistificação do papel transcendente da arte e da aura do artista. As linguagens são desierarquizadas, bem como os materiais e os temas. Nessa linha, entram os materiais comuns, as coisas do mundo, as ordinárias matérias-primas do processo criativo. O mesmo se dá com os temas-problemas que advém no cotidiano, da vida, da sociedade, da política. A ativação dos campos da política e da ética são ingredientes particulares, o que também irrompe com a ideia de neutralidade e de universalidade. A produção é contextual e, particularmente, articulada ao espaço que a acolhe. Este, por sua vez, não aparece como algo inerte, mas como algo dotado de vida e expressão, o espaço requer ausculta, é organismo vivo.

A rede e o exercício da coletividade também são elementos constituintes e operantes na sua produção que dialoga abertamente com muitas outras, mas que também se completa no retorno ao coletivo. Não se trata apenas de estar com outros, mas de ser com outros, a criação é, em si, um processo coletivo e transformador, assim ela se completa, gerando camadas e criando dissensos. Em seu processo de produção percebe-se que todos podem adentrar ao estado criativo, mas o artista não pode prescindir do repertório, dos conhecimentos técnicos e históricos para que possa mobilizar o campo estético, atritar o tangível e o intangível. Nesse sentido, a trajetória pessoal, a busca do conhecimento e a abertura para o aprender representam a sua própria condição de existência na condição de artista.

A concepção e a experiência com e da imagem ressoam aquilo que se materializa na produção artística. A finalidade não é uma obra, não porque inexista o tangível e até mesmo o comercializável, mas porque aquilo que assume a tangibilidade constitui uma parcela do trabalho. Ela é forma, traduzida em conjunto de operações, ações e interpretações. O processual emerge como elemento central na concepção e na forma de experienciar o trabalho artístico. 
Tanto a investigação, como a percepção se combinam e se articulam na promoção da experiência. Nesse sentido, a imagem é também conceito, é também pensamento! As intencionalidades regem o processo construtivo e se conformam nas relações. Elas comandam o processo criativo em termos de concepção.

A ativação das políticas cognitivas, dos procedimentos pedagógicos, parte de um pressuposto no qual se compreende a arte como dimensão do ser humano. Suplanta-se a ideia de arte-atividade, estado ao qual, em grande medida, está relegado o ensino da arte no Brasil. Na trajetória de artista-educadora Lucimar B. Frange fica evidente que o sentido educativo não está nas obras de arte em si, mas na interação com os conteúdos em relações intertextuais. O papel do educador não está circunscrito a passar informações, mas é, fundamentalmente, o de ativar o processo de experiência, despertando o estado criativo. Dessa forma, contribui para a completude do humano que está em cada sujeito.

Sua prática pedagógica, assim como a produção artística conectada a ela, requer o compartilhamento, a coletividade. Assim, propõe-se à prática permanente do coletivo, contaminando-a com os dissensos estéticos, criando elos de provocação do sujeito para fora de suas zonas de conforto, incitando a mobilização de elementos tangíveis e intangíveis. Compartilhar e horizontalizar são dois desafios da docência, sobretudo, fazê-lo sem incorrer na banalização.

Os resultados do estudo de caso revelaram profundo diálogo com o trabalho de outros artistas contemporâneos, alguns deles analisados no capítulo teórico e outras artistas educadoras que colaboraram com a pesquisa. A relação ética - política estética caminham juntas e fortalecem a perspectiva do contemporâneo, o mesmo se dá com a escolha dos elementos do cotidiano e sensibilidade para perceber e transformar materiais banais em processos de experiência estética. Esta prática/pensamento tem mais vinculação com o campo pedagógico na trajetória dos artistas-educadores, mas também se evidencia, de algum modo, nos artistas que não atuam nesse campo. De qualquer maneira, o que se vê são formas de agenciamento e estratégias de envolvimento e promoção da experiência que apresentam novos desafios para os arte educadores. Sobretudo, conclui-se que a pesquisa ratifica a hipótese de que a arte contemporânea amplia as possibilidades do campo educacional, explicitando a experiência como elemento do aprendizado, não sobre a arte culta, mas para a vida, para a construção do sujeito. 


\section{Apontamentos Finais}

O problema central desta pesquisa, articulado por meio da investigação sobre as práticas artísticas contemporâneas nas artes visuais e seus modos de apropriação no campo pedagógico, que definiu no trabalho da artista, educadora e pesquisadora Lucimar Bello Frange seu estudo de caso prático, permitiu uma outra compreensão do papel do ensino da arte, da experiência da, e com imagem no contexto do ensino contemporâneo da arte.

Contemporaneamente, o ensino da Arte no Brasil, em todos os níveis da Educação, tem sido afetado historicamente por processos variados. A importação de modelos externos, sem a necessária contextualização e sistematização teórica para a realidade brasileira, contribui para minimizar a relevância dessa área de conhecimento. No entanto, essa realidade vem se transformando. As ações de profissionais como Frange vem fornecendo uma ampla gama de possibilidades para que as pesquisas sobre o ensino a aprendizagem das artes continuem ampliando seu manancial de referência para a compreensão da multiplicidade e complexidade de se trabalhar com arte contemporânea na educação.

As transformações nas práticas artísticas, fundamentalmente, seus processos construtivos e constitutivos, aqui discutidos, trazem elementos para que as práticas pedagógicas sejam refletidas com base nos processos que não podem ignorar a unidade entre seus modos de concepção, produção e compartilhamento. É possível pensa-las como uma estratégia educativa na qual as imagens perdem seu carácter contemplativo e assumem a condição de análogo das próprias formas de ação estética. Transfiguram-se em práticas artísticas educacionais, nas quais o estético não deve ser subsumido pelo social, mas atue como coautor das maneiras de compreensão do mundo.

Se o trabalho do artista deixou de ser apenas a de produtor de objetos para se tornar um agente propositor de situações, um mobilizador do campo estético, um ativador das políticas cognitivas por meio da experiência com a imagem, é possível que suas práticas sejam compreendidas na esteira das transformações dos modos de existência no contemporâneo. 
As mudanças e evoluções nessas práticas, ainda não foram acompanhadas pela correspondente mutação e atualização das propostas do ensino da arte. Dessa forma, cabe nas ações educativas, a apropriação desses modos de operar como um processo de agenciamento para construção de territórios de autoria.

$\mathrm{Na}$ indissociabilidade entre prática artística e processo pedagógico, Lucimar Bello Frange propõe, como antítese às "fôrmas", sinônimo de obrigações, imposições, as "fórmas/imagens", frestas, compartilhamentos e "compartrilhamentos". Tratam-se de caminhos de acesso ao corpo semântico da arte. Às cartografias existenciais que podem ser acessadas por meio das camadas, procedimentos, ideias e situações propostas na produção contemporânea em artes visuais.

Este agenciamento pode ser tomado, tanto em seu modo conceitual, quanto nos processos de produção estética e de leitura nas artes visuais a partir do campo estendido de suas práticas. Conectando e reivindicando uma epistemologia própria para as investigações desenvolvidas por artistas. Uma proposta transdisciplinar que, seja capaz de gerar, a propósito do trabalho de Frange, uma outra noção epistemológica fundamentada nas interrogações estéticas.

O desafio da arte não é diferente daquele que se coloca para a educação, de forma mais ampla. No entanto, compreendendo e mobilizando as estratégias de artistas contemporâneos percebe-se que existem caminhos sendo trilhados e que provocam novos modos de pensar o hoje. Na poeticidade de João Cabral de Melo Neto 294 :

\section{Tecendo a Manhã}

Um galo sozinho não tece uma manhã: ele precisará sempre de outros galos. De um que apanhe esse grito que ele e o lance a outro; de um outro galo que apanhe o grito de um galo antes e o lance a outro; e de outros galos que com muitos outros galos se cruzem os fios de sol de seus gritos de galo.

Para que a manhã, desde uma teia tênue. Se vá tecendo, entre todos os galos.

${ }^{294}$ MELO NETO, J.C.. João Cabral de Melo Neto: Obra Completa. Editora Nova Aguilar: São Paulo, 1999. 
E se encorpando em tela, entre todos,

Se erguendo tenda, onde entrem todos,

Se entretendendo para todos, no toldo

(a manhã) que plana livre da armação.

A manhã, toldo de um tecido tão aéreo

que, tecido, se eleva por si: luz balão.

(A Educação pela Pedra) 


\section{Referências}

ADORNO, Theodor W. Teoria Estética. Lisboa: Edições 70, 1970.

ADORNO, Theodor W.; HORKHEIMER, M. Teoria da Cultura de Massa. Introdução, Comentários e Seleção de Luiz Costa Lima. Rio de Janeiro: Paz e Terra, 1986.

ALLIEZ, ÉRIC (org) . Gilles Deleuze: Uma vida filosófica. São Paulo, Editora 34, 2000. p.429

ANDREOLI, Elisabetta, e SANTOS, Laymert Garcia dos. Arte pública, cidade privada. In PEIXOTO, Nelson Brissac (org). Intervenções Urbanas: Arte/Cidade. São Paulo: Editora SENAC São Paulo, 2002.

ARGAN, Giulio Carlo. História da arte como história da cidade. Martins Fontes, São Paulo: 2005.

BARBOSA, Ana Mae. História da Arte-Educação. São Paulo: Editora Max Limonad, 1984.

. Tópicos Utópicos. Belo Horizonte: C/arte, 1998.

BAUMAN. Zygmunt. Sobre educação e juventude. Rio de Janeiro, Zahar, 2013.

BENJAMIN, Walter. O autor como produtor. In: A modernidade. Obras escolhidas de Walter Benjamin, [edição e tradução de João Barrento], Lisboa, Assírio \& Alvim, 2006.

O surrealismo, o último instantâneo da inteligência europeia. In: Obras escolhidas. Vol. 1: BENJAMIM, Walter. Magia e técnica, arte e política Ensaios sobre literatura e a história da cultura. Trad. Sérgio Paulo Rouanet, 1985.

BISHOP, Claire. "artificial hells: participatory art and the politics of spectatorship", chapter 9 - in: 'Pedagogic projects:' how do you bring a classroom to life as if it were a work of art ', i.arte of conduct, ed Verso?. July 17, 2012. Brooklyn, new york, united states (fig.) pp. 241-250

BOURDIEU. Pierre. Economia das Trocas Simbólicas. São Paulo: Perspectiva, 2007.

BOURRIAUD, Nicolas. Estética Relacional. Tradução de Denise Bottmann. São Paulo: Ed. Martins Fontes, 2009.

BRUGUERA, Tania. TANIA BRUGUERA. Cátedra Arte de Conducta. Glosario, s/d. Disponível em: http://www.taniabruguera.com/cms/492-1Ctedra+Arte+de+Conducta.htm . Acesso em: 12/30. 2014. 
BUCK-MORSS, Susan. Estética e anestética: uma reconsideração de A obra de arte de Walter Benjamin. In: Benjamin e a obra de arte. Técnica, imagem, percepção/ Walter Benjamin [et al.]; trad. Marijane Lisboa Vera Ribeiro; org, Tadeu Capistrano. Rio de Janeiro: Contraponto, 2012.

CLARK. Lygia. Carta a Hélio Oiticica, de 26/10/1968, in Lygia Clark e Hélio Oiticica. Funarte, Rio de Janeiro, 1987.

. Carta a Mário Pedrosa, 1967; In: Sonia Lins, Artes, 1996.

. Lygia Clark - Hélio Oiticica: Cartas, 1964-74. Rio de Janeiro: UFRJ.

CESAR, Marisa Flórido Cesar. 0 artista e a cidade. Transformações na prática artística: entre a rua e o aletiê. Curso de História da Arte oferecido pela Pinacoteca do Estado de São Paulo. 2011. Disponível em: https://www.youtube.com/watch?v=f1Sp EwnSD5k . Acessado 25/04/2014.

Nós, o outro, o distante na arte contemporânea brasileira. Rio de Janeiro: Editora Circuito, 2014.

. Como se existisse a Humanidade. In: Revista do Programa de PósGraduação em Artes Visuais EBA - UFRJ. Ano 14,n. 15, p.17-25, 2007.

DANTO, A. Após o fim da arte: a arte contemporânea e os limites da história. São Paulo: Odysseus, 2006.

DELEUZE, D. Deleuze no vídeo “ L'abécédaire de Gilles Deleuze”, filmado em 1988 por Claire Parnet.

. Bergsonismo. Tradução de Luiz Orlandi. São Paulo: Ed. 34 Letras,1999.

. Espinosa e a Filosofia Prática. Tradução de Daniel Lins e Fabien Pascal Lins. São Paulo: Escuta, 2002.

Francis Bacon: Lógica da sensação. Rio de Janeiro: 2007.

. Lógica da Sensação. Rio de Janeiro: Jorge Zahar Editora, 2007.

. Francis Bacon: Lógica da sensação. Rio de Janeiro: 2007.

Conversações. Trad. Bras. Peter Paul Pelbart. São Paulo: Ed. 34. 1992.

DELEUZE, G.; GUATARRI, F.. Mil Platôs: capitalismo e esquizofrenia. Vol.1. Rio de Janeiro, Editora 34, 1995.

DEWEY, John. Arte como experiência. Martins Fontes, 2010.

Democracia e Educação: breve tratado de filosofia da educação. Tradução Anysio Teixeira. São Paulo: Cia Nacional, 1959. 
. Lógica: a teoria da investigação. In: Os pensadores. São Paulo: Abril Cultural, 1980.

DIDI-HUBERMAN, G. O que vemos o que nos olha. São Paulo: Martins Fontes, 2003.

DUARTE, R.. Entrevistas em pesquisas qualitativas. IN: Educar, Curitiba, n.24, p. 213-224, 2004.

DUARTE JÚNIOR. João Francisco. A montanha e o videogame: Escritos sobre educação. São Paulo: Papirus, 2010

DUROZOI, G. e ROUSSEL, A. Dicionário de Filosofia. Tradução de Marina Appenzeller. Campinas, SP: Papirus, 1993.

DUVE. Thierry de. Cinco reflexões sobre o julgamento estético. In: Revista Porto Arte: Porto Alegre, V. 16. N. 27, novembro/2009.

. Kant depois de Duchamp. In: Revista do Mestrado em História da Arte EBA. UFRJ, 1998.

EISNER. Elliot Wayne. Arts based Research. Los Angeles: Sege Publications. inc.,2012.

EISNER. Elliot Wayne. O que pode a educação aprender das artes sobre a educação? In: Currículo sem Fronteira, v.8, n.2,pp.5-17, jul/Dez 2008. Acessado em: 14/10/2014. Disponível em: http://www.curriculosemfronteiras.org/vol8iss2articles/eisner.pdf.

FAVARETTO, Celso. Inconformismo Estético, Inconformismo Social, Hélio Oiticica. In: Fios Soltos: a arte de Hélio oiticica. Paulo Braga (org). São Paulo, Ed. Perspectiva, 2011.

FIGUEIREDO, L., (org.), (1996). Lygia Clark - Hélio Oiticica: Cartas, 1964-74. Rio de Janeiro: UFRJ.

FINKELPEARL, Tom. "Behavioral Cadeira Art" O que nós fizemos, Capítulo 7: Art Educacional. Ed. Duke University Press Books. 15 de janeiro de 2013. Nova lorque, Estados Unidos (fig.) pp. 179-203.

FOSTER, Hal. The artist as ethnographer. In: The return of the real. 3. ed. Cambridge; London: MIT Press, 1999, pp. 171-204.

FOUCAULT. Michel. Outros espaços. In: Ditos e escritos III. Rio de Janeiro: Forense Universitária, 1995.

. A hermenêutica do sujeito. 2004. São Paulo: Martins Fontes. p. 290. 1987.

Vigiar e punir: nascimento da prisão. Trad. Raquel Ramalhete, Vozes, 
FRANGE, Lucimar Bello. A Experiência estética em ações colaborativas, inquietantes. Poéticas em práticas pedagógicas. In: XXIII CONFAEB, Porto de Galinhas/PE - Anais, 2013. p. 3414.

FRANGE, L. B. P. . Noemia Varela e a Arte. 1a. ed. Belo Horizonte: C/Arte, 2001. v. 01. 273p.

Ato criador, blocos de experimentações. In: Revista APOTHEKE. Santa Catarina,,v.2, n.2, fevereiro de 2016.

. Critical Studies in Art Education: a Vision and a Brazilian Interpretation. In: Arte e Design Education. 1993.

Por que se esconde a violeta. Esta não é uma concepção de desenho, nem pós-moderna, nem tautológica. São Paulo, ANNABLUME, 1995. p.115.

SamPer, cartografias cidadianas; dos Alpes ao Ilhade Capri Disponível em http://anpap.org.br/anais/2007/2007/artigos/146.pdf Acessado em 25/06/20. p.p 1439 - 1448

Cidades desenhantes, um desnorte. In: Anais XIX ANPAP. Cachoeira: UFBA, 2010 (p.1439-1452). p. 1440.

A Experiência estética em ações colaborativas, inquietantes. Poéticas em práticas pedagógicas. In: XXIII CONFAEB: Porto de Galinhas/PE - Anais, 2013. p. 3414.

Acerca das Cartografias Cidadianas de Lucimarbello da Vila Olímpia. 2006, p.5. Disponível em www.lucimarbello.com.br . Acessado: 23/12/2014.

. Critial Studies in Art Education: a Vision and a Brazilin Interporetation. In: Arte e Desegn Education. 1993, p.377.

. Arte, cultura e educação; Alguns pressupostos. In: Caderno de Discussão do centro de Pesquisa Sociossemiótica. São Paulo, 2001. Pp. 231-232.

. Cartas de chuva mansa. 2012. Fonte: acervo da artista. Disponível em www.lucimarbello.com.br.

Cartas de vírgulas paradas tênues. 2012. Fonte: acervo da artista. Disponível em www.lucimarbello.com.br.

FRANGE, Lucimar Bello. VASCONCELOS, Luiz Gonzaga Falcão (Org). Oficina de desenho urbano: desenhando e construindo a cidade no cerrado. Universidade Federal de Uberlândia / PROEX, 2004.

GADAMER, H.G. La actualidad de lo bello. El arte como juego, símbolo y fiesta. Ediciones Paidós Iberica, S.A. 1991. Barcelona. p. 36. 
Verdade e método - Traços fundamentais de uma hermenêutica filosófica. Ed. Vozes: Petrópolis, RJ, 2005. p.154

GIDDENS, A. As consequências da modernidade. São Paulo, Unesp, 1991.

GOLDBERG, RoseLee. Ser Cubano (entrevista com Tania Bruguera) Tradução: Caroline Alciones e Luiz Sérgio de Oliveira. In: Poieses/ Revista do Programa de Pós-Graduação em Estudos Contemporâneos das Artes, (p. 123 a 136), 2013.

GORDILHO, Viga (org). BTS em retalhos. Ações poéticas em cinto portos da Baía de Todos os Santos: Baiacu, Itaparica, Matarandiba, Coqueiros e llha de Maré. EDUFBA, Salvador, Bahia, 2013.

GUATTARI, F.; ROLNIK, S. "Cultura: um conceito reacionário?". In: Micropolítica: cartografias do desejo. Petrópolis: Vozes, 1996.

GUATTARI, Félix. Da produção da subjetividade. In: Caosmose: um novo paradigma estético. Rio de Janeiro: Ed.34, 1992.

HAESBAERT, R.. O Mito da Desterritorialização - do "fim dos territórios" à multiterritorialidade. Bertrand Brasil, Rio de Janeiro, 3ª edição, 2004.

HELGUERA, P. HOFF. (Orgs). Pedagogia no campo expandido/ Organização; Pablo Helguera e Mônica Hoff; Tradução Camila Pasquetti. Porto Alegre: Fundação Bienal de Artes Visuais do Mercosul, 2011.

JOQUERA, C.C..A arte perdeu seus fundamentos metafísicos. In: Entrevista com Ticio Escobar. 21/4/2014. Acessado em 12 de novembro de 2014. Disponível : www.blog.caroinc.net/sobre-limites-y-posibilidades-entrevista-aticioescobar.

KANT, Immanuel. Crítica da Faculdade do Juízo. Trad. Valério Rohden e Antônio Marques, Rio de Janeiro: Forense Universitária, 2008.

KUJAWSKI, Gilberto de Mello. A crise do século XX. São Paulo: Ática, 1988.

LADDAGA, Reinaldo. Estética da emergência: a formação da outra cultura das artes. Tradução Magda Lopes - São Paulo: Martins Fontes, 2012.

LÉTOURNEAU. Jocelyn. Ferramentas para o pesquisador iniciante. Trad. Ivone C. Benedetti. Editora Martins Fontes. São Paulo, 2011. p.100,101.

LUHMAN, N. Introdução à teoria dos sistemas: aulas publicadas por Javier Torres Nafarrate. Trad. Ana Cristina Arantes Nasser. Petrópolis: Vozes, 2010.

MANATA, Franz. Coisas a fazer. Lucimar Bello. Galeria de arte Espaço Cultural do Mercado. Disponível em http://lucimarbello.com.br/site/wp- 
content/uploads/2011/12/C\%C3\%B3pia-de-coisas-a-fazer-2.pdf.

Acessado23/04/2004.

MEIHY, José Carlos Sebe Bom. HOLANDA, Fabíola. História Oral - Como fazer, como pensar. São Paulo: Contexto, 2007.

MELO NETO, João Cabral. Entrevista concedida à Nícolas Extremera Tapia. Universidade de Granada, Espanha, 1993.

MINAYO,Cecília de Souza (org); GOMES. Suely Ferreira Deslandes Romeu. Pesquisa social. Teoria, método e criatividade, 34 ed. Editora Vozes, 2015.

MIYADA, P. Marcela Tiboni: Arsenal - Entrevista concedida a Paulo Miyada. Disponível em: http://goo.gl/TseogW Acesso em 15 de agosto de 2014.

MORA, José Ferrater. Dicionário de Filosofia. São Paulo: Martins Fontes, 2001.

MORIN, Edgar. Introducción al pensamiento complejo. Barcelona: Gedisa, 1996.

. O cinema ou o homem imaginário. Lisboa: Relógio D’Água, 1997.

. O método, 1. A natureza da natureza. 2 ed. Tradução Maria Gabriela de Bragança. Publicações Europa-América. 1977, p.52.

NAKOV, Andrei Boris. "Notice Biographique". In TARABOUKINE, Nikolay. Le Dernier Tableau/ Du Chevalet à la Machine. Pour une Théorie de la Peinture/ Écrits sur l'art et l'histoire de l'art à l'époque du constructivisme russe. Presentés para A. B. Nakov, trad. du russe par Michel Pétris et Andrei B. Nakov. Paris, éditions Champ Libre, 1980.

OITICICA, Hélio. Experimentar o Experimental, 1972. IN: BRAGA, P. (Org.) Fios soltos: a arte de Hélio Oiticica. São Paulo: Perspectiva, 2011.

OSBORNE, Harold. Estética e teoria da arte - Uma introdução histórica. São Paulo: Cultrix, 1968.

RABAÇA, Silvio Roberto. Variantes Críticas: a Dialética do Esclarecimento e o Legado da Escola de Frankfurt. São Paulo: Annablume, 2004.

RANCIÉRE, Jacques. A partilha do sensível. Tradução de Mônica Costa Netto, São Paulo: EXO Experimental org, Ed. 34, 2005.

Le ressentiment anti-esthétique. Magazine Littéraire, n. 414, nov. 2002.

RANCIÉRE, Jacques. 0 destino das imagens. Trad. Mônica Costa Netto; Organização Tadeu Capistrano. Rio de Janeiro: Contraponto, 2012.

Política da arte. Tradução Mônica Costa. Conferência realizada em abril de 2005, no seminário Práticas estéticas, sociais e políticas em debate. São 
paulo: $\quad$ Sesc Belenzinho. Disponível em ww2.sescsp.org.br/sesc/images/upload/conferencias/2006.rtf. Acessado em: 25/08/2014.

Sobre políticas estéticas, Barcelona, Museo de arte contemporáneo de Barcelona (MACBA), zoos.

. Le partage du sensible: esthétique et politique. Paris: La fabrique éditions, 2000.

Aisthesis. Scènes du régime esthétique de l'art. Paris: Galilée, 2011.

O destino das imagens. Trad. Mônica Costa Neto; Org, Tadeu Capistrano - Rio de Janeiro: Contraponto 2012.

READ, Herbert. Educação pela arte. Tradução: Ana Maria Rabaça e Luís Felipe Silva Teixeira. EDIÇÕES 70, Ida, 2007. EUA, 1971.

Anarchy and order essays in politics Faber. Beaccon Press, BostonREVERDY, Pierre. 1889-1960. s/p 1960.

RIZZI, M.C. S.L.. Reflexões sobre a abordagem triangular do ensino da arte. IN: BARBOSA, A.M. (org.) Ensino da arte: memória e história. São Paulo: Perspectiva, 2008, pp. 335-348.

ROCKWELL, E. "Etnografia e teoria na pesquisa educacional". In: Ezpeletta, J. e Rockwell, E. Pesquisa participante. São Paulo, Cortez, 1986.

ROSENTHAL, Dália. O elemento material na obra de Joseph Beuys. Dissertação de Mestrado, Universidade Estadual de Campinas. Instituto de Artes, Campinas-SP, 2002.

STAKE, Robert. E. Pesquisa qualitativa: Estudando como as coisas funcionam. Penso Editora. Porto Alegre, 2011.

SUASSUNA. Ariano. Iniciação à estética. Editora José Olympio. São Paulo, 2004.

TIBONI, Marcela. In: Marcondes, Renan. Texto escrito a partir da entrevista realizada em 05 de agosto de 2014, na Galeria de Arte (São Paulo). Fonte: http://performatus.net/perfil-de-artista/as-armas-de-marcela-tiboni/ Acessado em 05/06/2015.

TROMBETA, Gerson Luís. A Racionalidade Artística como Contraponto À Racionalidade Instrumental. Revista Filosofia e Ciências Humanas. Passo Fundo, Ano 11, №. 01, Janeiro/Julho de 1995, p. 77-89

YIN, Robert K. Estudo de caso. Planejamento e métodos. Tradução: Ana Thorell; 4 ed.-Porto Alegre: Bookman, 2010, p.07 -22. 
ZANINI. Walter. História geral da arte no Brasil. São Paulo: Instituto Moreira Sales, Fundação Djalma Guimarães, 1983. p.73.

ZATTI, Vicente. Autonomia e educação em Immanuel Kant e Paulo Freire. Porto Alegre. EDIPUCRS, 2007. p.73.

ZOURABICHIVILI., François. O vocabulário de Deleuze. Tradução André Telles. Ed. Sinergia - Relume - Dumará: Rio de Janeiro, 2004. p.24. DELEUZE, 1992.

\section{Fontes Complementares (Lucimar Bello Frange)}

FRANGE, L. B. P. . Arte e seu ensino, visualidades e visibilidades. In:Arte na Escola Boletim 31, InstitutoArtenaEscola, v. 31, p. 06-07, 2003.

O apagamento como efeito de sentido e não como um desfazimento. Abordagens Contemporâneas Em Educação e Cultura, Montenegro, RS, 2000.

Critical Studies, arte e ensino de arte; uma visão e uma interpretação brasileira.In: Caderno de Arte Nupaad, Uberlândia - EDUFU, v. Especi, p. 45-54, 1998.

O desenhamento em Kiefer, Baselitz, Penck, Schnabel, Basquiat, McCollum, Chia, Cucci, Clemente, Nash, Goldsworthy.In: Caderno de Arte do Nupaad, Uberlândia - EDUFU, v. Especi, p. 153-167, 1998.

. Arte e comunidade, uma pesquisa possível sobre desenho.In: Revista Raízes e Rumos, Rio de Janeiro, UFRJ, v. 3, n.5, p. 34-40, 1996.

Arte e Comunidade, uma pesquisa possível sobre desenho.IN: Revista Raízes e Rumos, RJ, UFRJ., v. 3, n.5, p. 34-40, 1996.

Art \& Community; a possible drawing research.In: INSEA NEWS, Journal of $\overline{\text { Art }}$ and Design Educ, v. 2, n.3, p. 7-9, 1995.

BELLO, P. L. ; FRANGE, L. B. P. . Arte, Cultura e Universidade.In: Ensino Em Re Vista, Uberlândia, EDUFU, v. 3, n.1, p. 59-68, 1994.

. Critical Studies, a Brazilian vision, an interpretation.In: Journal Of Design And Design Education, v. 12, n.03, p. 377-385, 1993.

. Um olhar, um adentrar Foucaultiano: as questões da Arte Educacao no Brasil. OLHO LATINO, v. 01, n.01, p. 28-31, 1991.

Manifestos - 1. Desenho e Ensino de Desenho - 2. Cidades Utopicas. In:EDUCACAO E FILOSOFIA, Uberlândia, EDUFU, 1990. 
Subjetividade instituida, subjetividade instituinte; a subjetividade instituindo-se na Modernidade.In: Educação e Filosofia , Uberlândia - EDUFU, v. 04, n.7, p. 128-139, 1989.

Brinquedos e brincadeiras esquecidas; uma exposição de Artes Plásticas e uma experiência em Arte Educação. In:Revista Educaçãp e Filosofia, Uberlãndia - EDUFU, v. 3, n.5/6, p. 219-227, 1988. $\overline{62 p}$.

Caracol é uma casa que se anda. 1a. ed. São Paulo: Labrador, 2016. v. 1.

SETE VIRA UM, literatura e artes visuais. 1a.. ed. São Paulo: Editora Independente, 2015. v. 50. 29p.

MARTINS, M. V. G. ; FRANGE, L. B. P. ; FORTES, H. ; DANTAS, G. In:. BTS em retalhos, ações poéticas em cinco portos da Baía de Todos os Santos Org. Viga Gordilho. 1a. ed. Salvador: UFBA, 2013. v. 1000.

MARTINS, M. V. G. ; HERNÁNDEZ, M. H. O. ; FRANGE, L. B. P. In:. Entre territórios. 19 Encontro da ANPAP. Org. Viga Gordilho e Maria Herminia 0. Hernández. 1a. ed. Salvador: EDUFBA, 2011. v. 1. 256p .

FRANGE, L. B. P. ; VASCONCELOS, L. G. F. (Org.) . Oficina de Desenho Urbano: desenhando e construindo a Cidade no Cerrado. Uberlândia: EDUFU, 2002. v. 1000. $198 \mathrm{p}$.

FRANGE, L.P, Falcão . Oficina de Desenho Urbano. As Crianças, os Jovens e a Cidade no Cerrado. 1a.. ed. Uberlândia: EDUFU, 2002. v. 1000. 198p .

Noemia Varela e a Arte. 1a. ed. Belo Horizonte: C/Arte, 2001. v. 01. 273p .

Porque se esconde a violeta? Isto não é uma concepção de desenho, nem pós-moderna, nem tautológica. 1a. ed. Uberlândia/ São Paulo: EDUFU e ANNA BLUME, 1995. v. 01. 339p .

IORIO, M. ; FRANGE, L. B. P. . Regina Rodrigues. In: Mary Di lorio. (Org.). In: A Cerâmica no Brasil, sistematização bibliográfica. 1a.ed.: , 2015, v. 01, p. 125125.

Fabricações e Invenções. In: Moema Rebouças e Maria Dadalto Gorete. (Org.).In: Educação na arte contemporânea. 1a.ed.Vitoria: EDUFES, 2015, v. 346, p. 66-93.

cidade\{i\}móvel, um desafio cidadiano. In: Ana Claudia de Oliveira. (Org.). Do sensível ao inteligível, duas décadas de construção de sentido. 1ed.Sorocaba: OJM Casa Editorial, 2014, v. 01, p. 351-372.

FRANGE, L. B. P. ; TINOCO, E. F. V. ; FRANCA, L. C. Z. ; REDUCINO, M. O. . Visitas \& Encontros, Visitamentos \& Encontramentos. In: Eliane de Fátima Vieira Tinoco e Léa Carneiro de Zumpano França. (Org.). Artes Visuais, ensino e 
aprendizagem. Experiências da Rede Pública Municipal de Uberlândia. 1aed.Uberlândia: Produção Independente, 2012, v. , p. 09-240.

Cidades Desenhantes, um desnorte. In: GORDILHO,Viga (Org.) ; HERNÁNDEZ, Maria Herminia (Org.) ; REY, S. (Org.) ; DOMÉNECH, Maribel (Org.) ; VILLIERS, Celia de (Org.). (Org.). Entre territórios. 1aed.Salvador: EDUFBA, 2011, v. 01, p. 113-131.

Arte e Educação; diversos olhares. In: Ayrton Dutra Corrêa. (Org.). Ensino de Artes, múltiplos olhares. ljuí, RS.: UNIJUÍ, 2002, v. , p. - .

Arte e seu Ensino. In: Ana Mae Barbosa. (Org.). Inquietações e Mudanças no Ensino de Arte. São Paulo: Cortez, 2002, v. , p. -

Brazilian Connections between Fine Art and Art Teaching since the 1920s. In: Kerry Freedman; Fernando Hernández. (Org.). Curriculum, Culture and Art Education; comparative perspectives. Albany, NY: State University of New York Press, 1998, v. , p. - .

Imagens - Imagizadas: Nadadeiras Para Sobrenadar. In: IIma Alencastro Veiga. (Org.). Curriculo de primeiro grau, uma proposta. Uberlândia e Campinas: EDUFU e PAPIRUS, 1990, v. , p. 139-156.

BITTENCOURT, E. ; FRANGE, L. B. P. . Formas de Poesia. Correio Braziliense, 25 jul. 2014.

FRANGE, L. B. P. ; MARTINS, M. V. G. ; DANTAS, G. . Pintando com o tauá na Comunidade de Coqueiros, aproximações arte e química.In: Revista Virtual de Química, Salvador, p. 534 - 550, 06 nov. 2012.

. Entrevista com Regina Silveira.In: Arte na Escola - Edição de Outono, São Paulo, São Paulo, p. 04 - 05, 04 abr. 2004.

. Arte, Cultura e Educação: diversos olhares. Conversas terceiro-milênicas com Paulo Freire e com Noemia Varela. In:Revista de Educação Popular, EDUFU Uberlândia, , v. 01, 20 fev. 2003.

Multiculturalismo e Educação Crítica. In:Revista Especial da Educação Física. Planejamento Coletivo do Trabalho Pedagógico - PCTP; a experiência em Uberlândia, EDUFU - Uberlândia, , v. 1, p. 53 - 62, 20 fev. 2002.

FRANGE, L. B. P. . Arte e Comunidade, uma possível pesquisa sobre desenho. In:Revista Raízes e Rumos, UFRJ - Rio de Janeiro, , v. 3, p. 34 - 40.

L. Processos criativos em arte educação, experimentações e práticas compartilhadas. In: XXVI CONFAEB - Congresso Nacional da Federação de Arte Educadores do Brasil, 2016, Boa Vista. Anais do XXVI CONFAEB. Boa Vista: EDUFRR, 2016. v. 1. p. 294-301. 
. In(com)sistências experimentais e colaborativas. In: XXIV CONFAEB, 2014, Ponta Grossa. Anais CONFAEB. Ponta Grossa: FAEB - UEPG(DESRTES/PPGE) - CLEA, 2014. v. 01.

. Fala.Oficina.Pensamento. In: 23ํㅡㄹ Encontro da ANPAP, 2014, Belo Horizonte. 23ํㅡㄹ Encontro Nacional da ANPAP. Belo Horizonte: UFMG, 2014. v. 01. p. 23682384.

A experiência estética em ações colaborativas, inquietações. In: XXIII CONFAEB - ARTE/EDUCAÇÃO NO PÓS MUNDO, 2013, Porto de Galinhas. XXIII CONFAEB. Belém do Pará: UFPA, 2013. p. 3412-3426.

Desenhos de Comer, cerâmicas para viver, Desenhos de Comer, para Itaparica e Travessias, três experimentações. In: 220 Encontro Nacional da ANPAP, 2013, Belém do Pará. 22ํㅡㄹ Encontro Nacional da ANPAP. Belém do Pará: UFPA, 2013.

. Cidades Desenhantes, um desnorte. In: 19 Encontro Nacional da ANPAP Entre Territórios, 2011, Cahoeira, Bahia. Entre Territórios 19 Encontro Nacional de Pesquisadores dem Artes Plásticas. Salvador: EDUFBA, 2011. p. 113-131.

Cantos-Cunhas $61,62,502,1501,61$. In: Subjetividades, Utopias e Fabulações, 2011, Rio de Janeiro. Anais do ... Encontro Nacional da ANPAP (Cd-Rom). Rio de Janeiro: Ed UERJ, 2011. v. 1. p. 3880-3889.

Cidades desenhantes, um desnorte. In: 19ํㅡㄹ Congresso da ANPAP, 2010, Cachoeira. Anais do ... Encontro Nacional da ANPAP (Cd-Rom). Salvador: EDUFBA/virtual, 2010. v. 1. p. 1439-1452.

FRANGE, L. B. P. . vasas.cidades. dos Alpes ao llha de Capri. In: 18 Congresso da ANPAP, 2009, Salvador. Anais do ... Encontro Nacional da ANPAP (Online). Salvador: UFBA, 2009. v. 1. p. 838-846.

FRANGE, L. B. P. ; REBOUÇAS, M. . O entre-espaço da escola na cidade. In: Colóquio do CPS/COS/PUC/SP, 2008, São Paulo. In:Caderno de Discussão de Centro de Pesquisas Sociossemióticas. São Paulo: PUC/SP, 2008. v. 1. p. 0112.

corpoCasasCidade. In: Panorama da Pesquisa em Artes Visuais, 2008, Florianópolis. Anais do ... Encontro Nacional da ANPAP (Cd-Rom). Florianópolis: Ed UFSC, 2008. v. 1. p. 1869-1874.

. Samper, cartografias cidadianas. In: Dinâmicas Episitemológicas em Artes

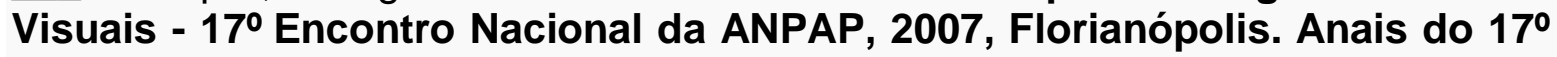
Congresso Nacional da ANPAP. Florianópolis: Ed UFSC, 2007. v. 1. p. 1869-1874.

Atravessamentos; de lençóis passados a lençóis amassados 15 Encontro Nacional da ANPAP. In: Cultura Visual e Desafios da Pesquisa em Arte - 15 
ENANPAP, 2006, Goiânia. Arte: Limites e Contaminações - 15 ENANPAP. Goiânia: Ed UFG, 2006. v. 2. p. 423-427.

Pesquisa no Ensino e na Formação de professores: caminhos entre visualidades e visibildades. In: XV Congresso da FAEB - CONFAEB, 2006, Brasília. Trajetórias e Políticas para o Ensino de Artes no Brasil. Coleção Educação para todos. Brasília: UNB, 2006. v. 1. p. 148-160.

FRANGE, L. B. P. ; BUORO, A. B. ; REBOUÇAS, M. . REBOUÇAS, M. L. M. ; BUORO, Anamélia Bueno ; FRANGE, Lucimar Bello . Semiotizando o ensino da arte: do fazer-saber ao fazer-ser. In: II Congresso Internacional: Brasil, identidade e alteridade, 2005, São Paulo. Congresso Internacional: Brasil, identidade e alteridade. São Paulo : Pontifícia Universidade Católica de São Paulo, 2005. v. 1. p. 01-10.. In: II Congresso Internacional: Brasil, identidade e alteridade, 2005. II Congresso Internacional: Brasil, identidade e alteridade.

FRANGE, L. B. P. ; BUORO, A. B. ; REBOUÇAS, M. . arte br da teoria à prática, da prática a teoria. Arte em pesquisa: especificidades.. In: 13을 Congresso da ANPAP, 2004, Brasília. 13ํㅡㄹ Congresso da ANPAP. Brasília: UNB, 2004. v. 02. p. 62-70.

FRANGE, L. B. P. ; BUORO, A. B. ; REBOUÇAS, M. . REBOUÇAS, M. L. M. ; BUORO, Anamélia Bueno ; FRANGE, Lucimar Bello . arte br: qualidades sensíveis e inteligíveis. arte br: qualidades sensíveis e inteligíveis, 2004. v. 1. p. 1-16.. In: XII Colóquio do Centro de Pesquisas Sociossemióticas, 2004, São Paulo. XII Colóquio do Centro de Pesquisas Sociossemióticas. São Paulo: CPS/PUC/SP, 2004. v. 01. p. 01-16.

FRANGE, L. B. P. . Desenho, uma condição desenhante; ações entre uma universidade e várias comunidades. In: A arte pesquisa, 2003, Brasília. XII Encontro Nacional da ANPAP. Brasília: Ed UNB, 2003. v. 2. p. 93-98.

FRANGE, L. B. P. ; REBOUÇAS, M. ; BUORO, A. B. . Arte, cultura e educação; alguns pressupostos (em equipe). In: VIII Colóquio do Centro de Pesquisas Sociossemióticas, 2002, São Paulo. Caderno de Discussão do Centro de Pequisas Sociossemióticas - VIII COlóquio. São Paulo: CPS - São Paulo, 2002. v. 01. p. 13-21.

FRANGE, L. B. P. ; BUORO, A. B. ; REBOUÇAS, M. . Arte, Cultura e educação: alguns pressupostos. In: VIII Colóquio do centro de Pesquisas Sociossemióticas,, 2002, São Paulo. VIII Caderno de Discussão do CPS. Londrina: Gráfica da UEL, 2002. v. v 01. p. 13-24.

FRANGE, L. B. P. . O apagamento como efeito de sentido e não como desfazimento. In: V Congresso Nacional de Arte Educação na Escola para todos, 2000, Brasília. Brasília, 2000.

Semiótica e História do Ensino de Arte. In: XXII Colóquio Brasileiro de História da Arte, 2002, Uberlândia. XXII Colóquio Brasileiro de História da Arte. Uberlândia: EDUFU, 2002. v. 01. 
Pontes do Recife, uma aquarela Noemiana. In: X Encontro Nacional da ANPAP, 1999, São Paulo. X Encontro Nacional da ANPAP. São Paulo: SESC/SP, 1999. v. 02. p. 242-245.

. Interfaces entre a sociedade pós moderna, a arte contemporânea e o ensino de arte. In: XI Congresso da FAEB, 1998, Brasília. XI CONFAEB, 1998. v. 01. p. 111-120.

. O desenho na arte contemporânea, paradigmas e paradoxos. In: IX Encontro Nacional da ANPAP, 1997, São Paulo. IX Encontro Nacional da ANPAP. São Paulo: SESC/SP, 1997. v. 02. p. 271-279.

. Drawing and teaching drawing. In: 4th. European Congress of INSEA, 1997, Glasgow. 4th European Congress of INSEA, 1997.

Desenho, uma construção MoebiusAna. In: Encontro Nacional da ANPAP, 1996, São Paulo. ANPAP 10 anos. São Paulo: EDUSP, 1996. v. 02. p. 282-287.

Desenho e Ensino de Desenho. In: II Congresso de Ciências Humanas, Letras e Artes, 1995, Uberlândia. Anais do II Congresso de Ciências Humanas, Letras e Artes. Uberlândia: EDUFU, 1995. p. 1391-39.

Arte e Ensino da Arte perante as transformações do mundo contemporâneo. In: VII ENDIFE, 1994, Goiânia. Anais VII ENDIPE. GOIANIA - GOIAS, 1994. v. 01.

Cidades Utópicas e Desenhos Desenhantes, uma trajetória andarilhante. In: VII Congresso da FAEB, 1994, Campo Grande. Experiências em Educação Estética em grupos diferenciados. Campo Grande: FUFMS, 1994. v. 01. p. 6777.

Conteudo Status Epistemológico da Multiculturalidade Brasileira. In: 6 Congresso da FAEB, 1993, Recife. 6 congresso da FAEB - Federação Brasileira de Arte Educadores. Recife - PE: Editora da UFPE, 1993. v. 01.

O desenho, a arte e a comunidade. In: I Congresso de Ciências Humanas, Letras e Artes, 1993, São João del Rei. I Congresso de Ciências Humnas, Letras e Artes, 1993. v. 01.

FRANGE, L. B. P. ; BUORO, A. B. ; REBOUÇAS, M. . Semiótica e Ensino das Artes Visuais.. In: IIII Encontro Internacional de Arte e Tecnologia e XII Encontro Nacional da ANPAP, 2003, Brasília. Semiótica e Ensino das Artes Visuais. Brasília: Editora UNB, 2003. v. 01. p. 13-16.

FRANGE, L. B. P. . Pesquisa sobre arte e seu ensino, anotações inquietas. In: II Encontro Internacional sobre Educação Artística, 2014, Juazeiro do Norte. 3ei_ea. Juazeiro do Norte: Ed Urca, 2014. v. 01. p. 173-178.

Cultura ou CULTURAS, uma questão dentre muitas questões. In: I1Simpósio de História e Cultura: Politica, Estética e Alteridade, 2002, Uberlândia. Caderno de Programação e Resumos, 2002. p. 43-44. 
. Discursos da arte e leitura semiótica. In: V Congresso Brasileiro de Semiótica, 2001, São Paulo. Semiótica e Representação. Inventariando para reinventar. São Paulo: FAPESP, 2001. v. 01. p. 45.

. Noemia Varela e a Arte na Educação. In: ANPAP Regional Encontro Recife, 2001, Recife. ANPAP Regional Recife. Recife: Ed. UFPE, 2001. p. 35.

Noemia Varela, uma sabedoria vivente. In: XI Ciclo de Estudos do Imaginário, 2000, Recife. Imaginário e Memória. Recife: Ed. UFPE, 2000. v. 01. p. 18.

. Desenho e Ensino de Desenho. In: XI CONFAEB, 1995, Florianópolis. XI Congresso da FAEB. Florianópolis: Ed. UDESC, 1995. v. 01. p. 98.

. Manhãs Desenhantes: ensino de desenho,. In: 3o Seminário de Extensão: Conhecimento e Reconhecimento, Universidade e Sociedade, 1995, Uberlândia. Resumo das Comunicações e da Mostra 3o Seminário de Extensão, 1995.

Imagens no Cerrado: arte e arquitetura. In: Primeira Reunião Especial da SBPC, 1994, Uberlândia. SBPC - Cerrado. Uberlândia - MG.: EDUFU, 1994. v. 01.

Images from images from the nineties. In: InSEA World Congress, 1993, Montréal. 27 INSEA World Congress, 1993. p. 56.

Vital Time \& Space, a personal expression of a profissional and specific art education and plastic art. In: 26 Congresso Mundial da InSEA, 1987, Hamburgo. 26th World Congress of InSEA. Hamburgo: inSEA, 1987. v. 01.

MARTINS, M. V. G. ; FRANGE, L. B. P. ; DANTAS, G. . Pintando com o tauá na comunidade de Coqueiros: possíveis aproximações entre Arte e Química no Projeto BTS. Revista Virtual de Química , 2012.

Arte Contemporânea, das exisências e da provocações. 2014. (Apresentação de Trabalho/Conferência ou palestra).

A experiência estética em ações colaborativas, inquietações. 2013. (Apresentação de Trabalho/Conferência ou palestra).

FRANGE, L. B. P. ; AMARAL, V. ; NUNES, ANA Luiza Ruschel . Da condição contemporânea da arte e seu ensino, considerações. 2013. (Apresentação de Trabalho/Conferência ou palestra).

Video Noemia Varela, de barro, de vidro, de barro, em Programação Artística. 2011. (Apresentação de Trabalho/Outra).

Artista.Pesquisador.Inquietações.Proposições. 2010. (Apresentação de Trabalho/Conferência ou palestra). 
FRANGE, L. B. P. ; MADELEINE, B. ; RODRIGUES, D. ; LOCCI, D. M. . Linguateca. Paraguay: Yiyi Jambo Cartonera, 2016 (Antologia de Novos Autores).

. Lágrimas em Proibido Para -In: Coletânea de autores. São Paulo: Edição Independente, 2013 (Jornal - Publicação Independente - Edição: Lucimar Mutarelli).

. . pesos.leves.pesos.levezasss.... São Paulo, Recife: Caixa Cultural Catálogo da Exposição Insustentável Leveza, de Giovana Dantas, Exposição Itinerante, 2011 (Texto de Apresentação em Exposição).

Apresentação no Catálogo: Insustentável leveza, de Giovana Dantas. Salvador, 2011. (Prefácio, Pósfacio/Apresentação)>.

FRANGE, L. B. P. ; REBOUÇAS, M. ; BUORO, A. B. ; KOK, B. ; COSTA, B. ; ATIHE, E. . arte br. São Paulo: Instituto Arte na Escola, 2003 (Material Educacional).

FRANGE, L. B. P. ; EQUIPE, E. ; Parte da produção do Projeto: Oficina de Desenho Urbano. As Crianças, os Jovens e a Cidade no Cerrado (Co-coordenação com Luiz Gonzaga Falcão Vasconcelos). Uberlândia: EDUFU, 2002 (Postais). 


\section{Anexo 01: Carta de autorização para uso das entrevistas}

Carta de autorização e uso das entrevistas

Carta $n^{\circ} 01$

Local: Residência da Professora Lucimar Bello Pereira Frange

Rua Aleixo Garcia, 51 - apt. 61 - Vila Olímpia - São Paulo - SP

Datas: 07/04/,1605, 16/06, e 05/09 de 2014 .

Destinatário,

Eu, Lucimar Bello Pereira Frange, documento de identidade $n^{\circ}$ (4.036.684.4 ), declaro para os devidos fins que cedo os direitos de minha entrevista, gravada, nos dias 07/04, 16/05, 16/06, e 05/09 de 2014, para a pesquisa de doutorado realizada pelo estudante de pósgraduação Carlos Weiner Mariano de Souza no. USP 5216563, sob orientação da professora Maria Christina de Souza Lima Rizzi no. USP 2085792, no âmbito do Programa de Pós-Graduação em Artes Visuais da Escola de Comunicações e Artes da Universidade de São Paulo, (PPGAV-ECA-USP) para usá-la integralmente ou em partes, sem restrição de prazos e de citações, ficando vinculado o controle da mesma aos arquivos de depoimentos de artistas do Departamento de Artes Plásticas da ECA/USP. Abdicando direitos sob a parte não relacionada, o que faço também aos meus descendentes, subscrevo a presente, que terá minha firma reconhecida em cartório.

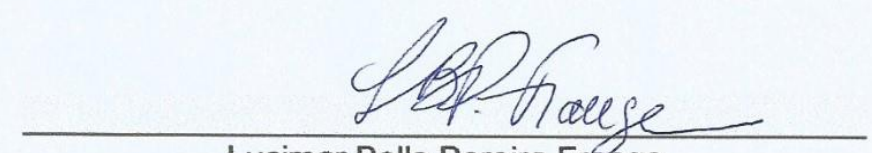

Lucimar Bello Pereira Frange 